\title{
Alluvial Fans, Loess Plains, Lakes, and Distributive Fluvial Systems: Depositional Systems of the Permian-Triassic Red Beds and Evaporites of Wyoming (USA)
}

Jonathan Knapp

West Virginia University, knapp1jp@gmail.com

Follow this and additional works at: https://researchrepository.wvu.edu/etd

Part of the Geology Commons, Sedimentology Commons, and the Stratigraphy Commons

\section{Recommended Citation}

Knapp, Jonathan, "Alluvial Fans, Loess Plains, Lakes, and Distributive Fluvial Systems: Depositional Systems of the Permian-Triassic Red Beds and Evaporites of Wyoming (USA)" (2020). Graduate Theses, Dissertations, and Problem Reports. 7933.

https://researchrepository.wvu.edu/etd/7933

This Dissertation is protected by copyright and/or related rights. It has been brought to you by the The Research Repository @ WVU with permission from the rights-holder(s). You are free to use this Dissertation in any way that is permitted by the copyright and related rights legislation that applies to your use. For other uses you must obtain permission from the rights-holder(s) directly, unless additional rights are indicated by a Creative Commons license in the record and/ or on the work itself. This Dissertation has been accepted for inclusion in WVU Graduate Theses, Dissertations, and Problem Reports collection by an authorized administrator of The Research Repository @ WVU.

For more information, please contact researchrepository@mail.wvu.edu. 
Alluvial Fans, Loess Plains, Lakes, and Distributive Fluvial Systems: Depositional Systems of the Permian-Triassic Red Beds and Evaporites of Wyoming (USA)

\author{
Jonathan Phillip Knapp \\ Dissertation submitted \\ to the Eberly College of Sciences \\ at West Virginia University
}

in partial fulfillment of the requirements for the degree of

Doctor of Philosophy

in

Geology

\author{
Kathleen Benison, Ph.D., Chair \\ Joseph Donavan, Ph.D. \\ Amy Weislogel, Ph.D. \\ Gerilyn Soreghan, Ph.D \\ James Thompson, Ph.D. \\ Department of Geology and Geography \\ Morgantown, West Virginia \\ 2020
}

Keywords: red beds, sedimentology, Chugwater Group, Goose Egg Formation, Red Peak Formation, Alcova Limestone

Copyright 2020 Jonathan Phillip Knapp 


\begin{abstract}
Alluvial Fans, Loess Plains, Lakes, and Distributive Fluvial Systems: Depositional Systems of the Permian-Triassic Red Beds and Evaporites of Wyoming (USA)

Jonathan Phillip Knapp
\end{abstract}

The end-Permian ecological crisis was a period of warming and aridity reaching extreme levels by the end Permian and not recovering before the Middle Triassic. The Permian Goose Egg Formation and the Chugwater Group's Early Triassic Red Peak Formation and Middle Triassic Alcova Limestone are a continuous or nearly continuous succession of rocks deposited during this warm, arid time in Wyoming. Comprised of red beds, evaporites, and rare carbonates, these rocks have not been subjected to detailed sedimentological investigations in the modern era. Previous interpretations of marine and marginal marine deposition have largely been based on the laterally extensive nature of bedding and the presence of gypsum and carbonate. However, chemical sedimentary rocks can form in diverse environments, and laterally extensive beds are common for paleosols, lakes, and loess. This dissertation is a detailed sedimentologic study undertaken to reconstruct depositional environments of the Permo-Triassic red beds and evaporites of Wyoming. For the first time, this study evaluates this succession's relationship to similar successions in Pangea's midcontinent. 3D models from areal imagery, centimeter-scale measured sections, detailed petrology, and microanalysis were utilized at central and eastern Wyoming locations to reconstruct environments, climate, and life from the Goose Egg Formation, the Red Peak Formation, and the Alcova Limestone.

The Goose Egg Formation was deposited in perennial and ephemeral saline lakes and associated continental facies. Eolian processes were an important sediment transport mechanism, with windblown silt and gypsum common. The Red Peak Formation was deposited in distal alluvial fans and ephemeral saline lakes. The red pigmentation of the Red Peak Formation is derived from: (1) impact reddening of grains during eolian saltation; (2) iron oxide cement or concretions formed in acid saline lakes and transported by the wind into the Red Peak Formation; and (3) in-situ pedogenic weathering in a near-surface oxygenated environment. The teleconnection to the acid saline lacustrine systems suggests acid saline systems were located upwind. The Alcova Limestone was deposited in perennial and ephemeral saline lakes after the groundwater table rose, likely from increased precipitation or decreased evaporation. At least some of the Alcova Limestone was likely originally deposited as gypsum and diagenetically altered to calcium carbonate after burial.

This study documents that the red bed, evaporite, and carbonate succession in the late Permian and Early Triassic in Wyoming were deposited in a continental environment of lakes and distal alluvial fans. Aridity increases during Goose Egg and into Red Peak time. The abrupt transition to the Alcova Limestone results from climatic or drainage system changes, perhaps a return to a more humid climate, a change in the drainage area's geology, or a change in the basin spill point. This study extends the environments of the Permo-Triassic red beds of North Dakota, South Dakota, and Kansas westward. These units are part of a wider red bed system in the American West associated with global aridity and extreme environments. 


\section{ACKNOWLEDGMENTS}

This work was only possible because of the kind support of my advisor, Kathleen Benison and my family, Phillip and Cynthia Knapp, Kendra and Jay Dangles. Also, I could not have finished without my friends and peers Sofia Andeskie, Meghan Davenport, Ossi Sariola, Mike McCormick, and Nigel Kelly. Sofia Andeskie and Beth Gergurich were capable field assistants, while Max and Boo Benison-Knapp were the best field-dogs.

Thank you to my committee for support and advice and West Virginia University for being such a welcome home. All my peers were helpful and supportive. Special thanks to Elliot J., my White Sands National Park family, Travis Nauman, C.P. Findley, Ben Johnson, Patrick Frier, Joe and Sarah Sanders, and the Pig and Sprout where most of this dissertation was written.

A special thanks to Chad Ostrander and Hitachi High Technology Canada, Jay, Kata, Thomas, and the entire Colorado School of Mines team, and Mona Serbescu. Also, thanks to my thin-section gurus Jay Erikson at CSM and Spectrum Petrographic for putting up with crazy requests. Funding for this Ph.D. was received from West Virginia University, the Clay Mineral Society, the National Science Foundation, and the Explorers Club. Partial funding was provided by NSFEAR grant 1317138 to Kathleen Benison. 


\section{TABLE OF CONTENTS}

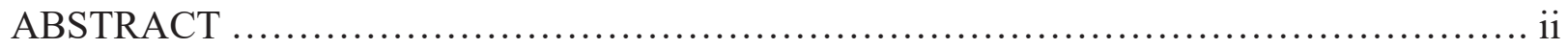

ACKNOWLEDGEMENTS ............................................................ ii

TABLE OF CONTENTS ....................................................................... iv

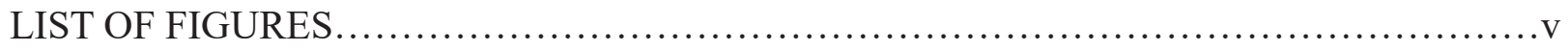

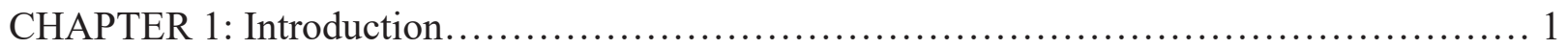

Research questions

Scientific and Social Significance

Organization of the Dissertation

CHAPTER 2: Saline lakes and loess in the Permian: paleoenvironments of the Goose Egg For-

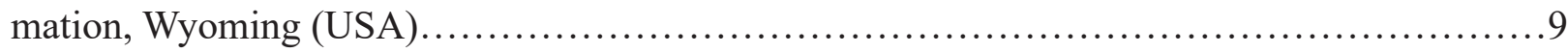

CHAPTER 3: The Permian-Triassic red beds of the Red Peak Formation, Wyoming (USA) Part I: Ephemeral lake deposits, loess, and alluvium modified by Ppedogenesis ...................67

CHAPTER 4: The Permian-Triassic red beds of the Red Peak Formation, Wyoming (USA) Part II: The origin of red pigment from pre-depositional and pedogenic processes

CHAPTER 5: The Alcova Limestone: saline lacustrine environments of the Triassic Chugwater

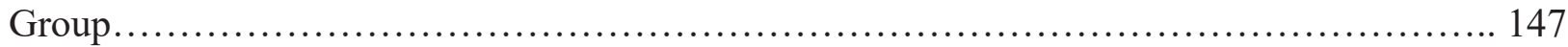

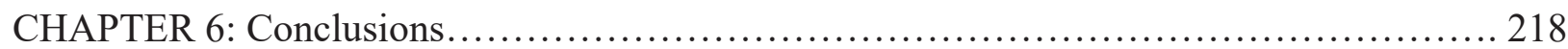

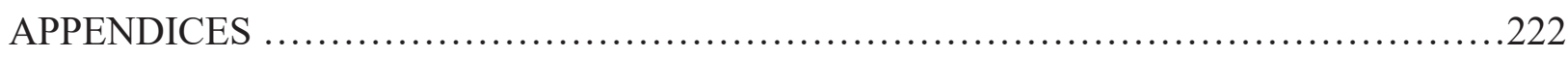

1. Willow Hill Elemental Concentration Data

2. Bulk semi-quantitative XRD Data

3. Automated Mineralogy Data from Red Peak Formation 


\section{LIST OF FIGURES}

\section{CHAPTER 1}

Fig. 1: Location and stratigraphy of the greater Permian and Triassic red bed system in western North America ......................................................................

Fig. 2: Overview aerial photograph showing the Goose Egg Formation. ......................

\section{CHAPTER 2}

Fig. 1: Location and stratigraphic nomenclature for the Goose Egg Formation. .............. 11

Fig. 2: Airborn imagery of the Goose Egg Formation.................................... 13

Fig. 3: Simplified stratigraphic sections......................................... 15

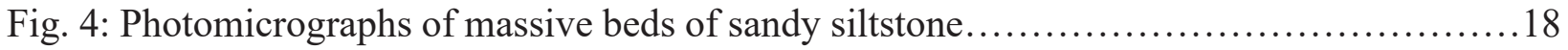

Fig. 5: Photomicrographs of Laminated Red Siltstone..................................19

Fig. 6: Photomicrograph from thin siltstone and sandstone lenses........................21

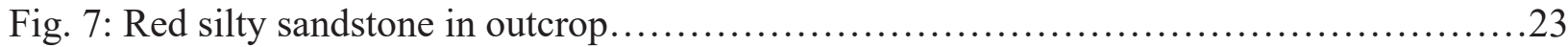

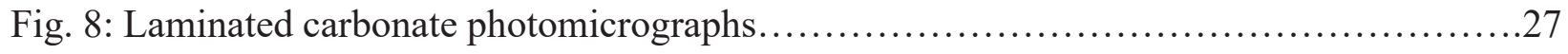

Fig. 9: Outcrop Details of Laminated Caroantes....................................... 30

Fig. 10: Bedded carbonate in outcrop............................................. 32

Fig. 11: Photomicrographs of the bedded carbonate lithofacies.......................... 33

Fig. 12: Rubble bed from the Bessemer Bend locality in outcrop and thin section............. 35

Fig. 13: Gypsum photomicrographs...............................................

Fig. 14: Gypsum in outcrop................................................... 37

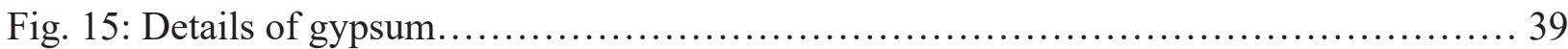

Fig. 16: Diagrammatic facies models............................................41

Fig. 17: Diagrammatic model for brine evolution................................. 51

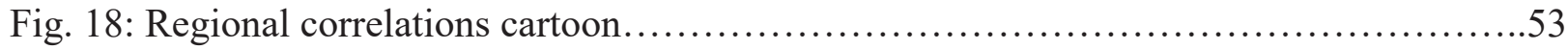

\section{CHAPTER 3}

Fig. 1: Location of major field sites for the Red Peak Formation.......................... 71

Fig. 2: Simplified stratigraphic nomenclature and correlations of major Permian and Triassic

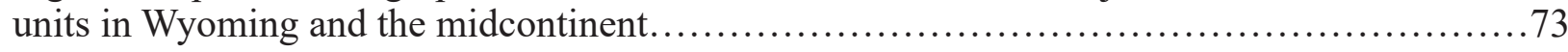

Fig. 3: Cliff-forming outcrops of the Red Peak Formation in Wyoming.................... 74 
Fig. 4 - Detailed measured sections from Willow Hill and Alcova Reservoir.

Fig. 5: Meter-scale measured sections in a transect from northwest to southeast along the Big-

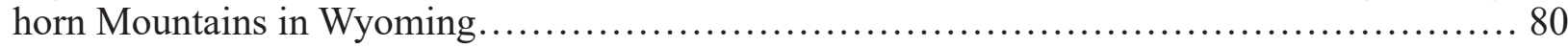

Fig. 6: Detailed stacking patterns and sediment arrangements........................ 81

Fig. 7: Details of sedimentary structures and features from resistant lithofacies............. 85

Fig. 8: Details of sedimentary features from ped-overprinted mudstone lithofacies........... 89

Fig. 9: Details of gypsum in outcrop............................................. 91

Fig. 10: Select examples of the laminated mudstone lithofacies...................... 94

Fig. 11: Details of siltstone and sandstone lenses lithofacies........................... 95

Fig. 12: Three example bedset couplets from the alternating lithofacies association and modal

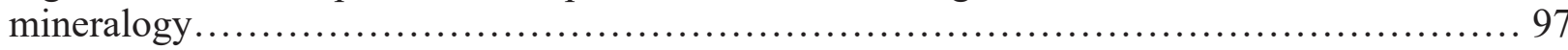

Fig. 13: Recent exposures providing examples of complex relationships of sedimentary features

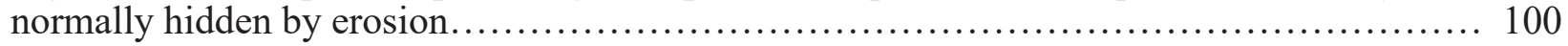

Fig. 14: Feldspar best-fit circle grain size distribution................................. 101

Fig. 15: Quartz best-fit circle grain size distribution.................................... 102

Fig. 16: Example photomicrographs from siltstones at Alcova Reservoir and Willow Hill.....105

Fig. 17: Example SEM automated mineralogy map from resistant lithofacies............. 108

Fig. 18: Example of SEM automated mineralogy map of recessive lithofacies............. 109

Fig. 19: Details of in-situ pedogenic micro-aggerates from recessive lithofacies.............. 111

Fig. 20: Details photomicrographs and elemental maps across the mud-rich pedogenic aggerate

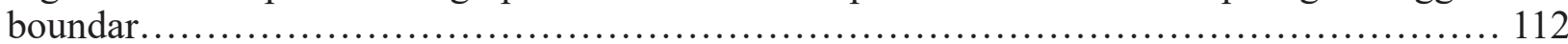

Fig. 21: Generalized model of Red Peak sedimentation............................... 113

\section{CHAPTER 4}

Fig. 1: Landscapes of the Red Peak Formation in Wyoming.......................... 135

Fig. 2: Regional location map of the Permian-Triassic red bed system in mid-continent North

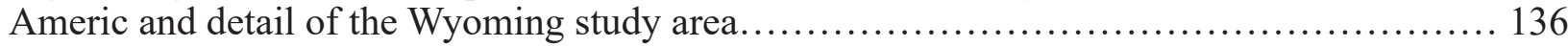

Fig. 3: Stratigraphic nomenclature and relationships in the Red Peak Formation........... 137

Fig. 4: Examples of Red Peak Formation features in outcrop.......................... 141

Fig. 5: Example XRF geochemical data from samples from the Will Hill locality............ 145

Fig. 6: Thin section photomicrographs from the Red Peak Formation...................... 147

Fig. 7: SEM backscatter electron images of the Red Peak Formation showing examples of grain 
details and sediment texture

Fig. 8: SEM backscatter electron image examples of detrital iron oxides.

Fig.9: Thin iron oxide coating on a broken quartz grain

152

Fig 10: Examples of thick iron oxide coatings with evidence of abrasions................. 153

Fig. 11: Example of iron-rich clay coatings around a quartz grain...................... 156

Fig 12: SEM backscatter electron and EDS examples of textures...................... 157

Fig. 13: Red pigment formation at or near Earth's surface .......................... 159

Fig. 14: Schematic diagram showing sediment transport and reddening..................... 160

Fig. 15: Schematic post-depositional paragenesis diagram............................. 161

\section{CHAPTER 5}

Fig. 1: Alcova limestone field locations in southeastern Wyoming....................... 172

Fig. 2: Stratigraphic context of the Alcova Limestone.................................. 173

Fig. 3: Measured Sections through the Alcova Limestone $. . \ldots \ldots \ldots \ldots \ldots \ldots \ldots \ldots \ldots \ldots . \ldots \ldots$

Fig. 4: The alternating red bed and calcareous sandstone lithofacies................... 179

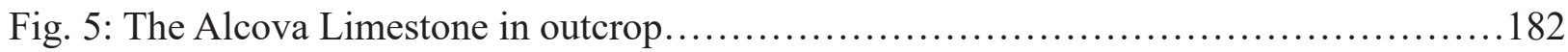

Fig. 6: The basal sandstone lithofacies............................................ 185

Fig. 7: The massive mudstone lithofacies in outcrop and thin section.......................188

Fig. 8: Elemental concentration maps of a thin section of the massive mudstone lithofacies from the Willow Hill locality......................................................... 190

Fig. 9: The wavy laminated lithofacies in outcrop..................................... 193

Fig. 10: Photomicrographs and elemental concentration maps wavy laminated lithofacies......195

Fig. 11: The bedded carbonate lithofacies in outcrop............................... 197

Fig. 12: Photomicrographs of the bedded carbonate lithofacies....................... 199

Fig. 13: The bedded carbonate lithofacies in photomicrograph and elemental maps......... 200

Fig. 14: Facies model for the deposition of the Alcova Limestone and associated units ..... 305 


\section{CHAPTER 1}

Introduction

\section{RESEARCH QUESTIONS}

A climatic and ecological crisis gripped Pangea from the late Permian to the Middle Triassic. Starting in the late Carboniferous, increasing aridification and warming transformed Earth's landscape and biology from icehouse to hothouse (Kutzbach and Gallimore, 1989; Dickins, 1993; Parrish, 1993; Royer et al., 2004; Tabor, 2013). By the mid-Permian global warming has been linked to tetrapod extensions (Lucas, 2017, and references therein), a reduction in plant diversity (Retallack, 2013), and perturbations in atmospheric circulation, weathering, and erosion (Tabor and Montañez, 2002; Retallack, 2013; Benton and Newell, 2014). Soils common in the Pennsylvanian (histosols, arigillsols, spodosols, and vertisols) disappear from the rock record by the early Middle Permian and are replaced by arid soils with calcretes and gypsum horizons (Gastaldo et al., 1996; Kessler et al., 2001; Mack et al., 2003; Retallack, 2013). Co-occurring with this long-term aridification and warming trend is the Siberian Trap volcanic eruptions starting at approximately 248 m.y.a and 600 to 900 k.y. These eruptions emitted massive amounts of $\mathrm{CO}_{2}$, $\mathrm{SO}_{2}$, and methane (Renne et al., 1995; Dorritie, 2002; Svensen et al., 2009) and could have been a major driver of global warming and acidification. This dissertation will examine a series of red beds, evaporites, and carbonates deposited during this period of extreme climate and environments in Wyoming to understand better the manifestation of that crisis in the midcontinent of Pangea.

The Goose Egg Formation and Chugwater Group represent a continuous or near-continuous accumulation of sediments from the mid-Permian to the Middle Triassic (Fig. 1). This dissertation will examine in detail the Goose Egg Formation and two formations of the Chugwater Group, the Red Peak Formation and the Alcova Limestone (Fig. 2). These units are stratigraphically situated between the eolian and lacustrine deposits and paleosols of the underlying late Pennsylvanian to early Permian Minnelusa Formation and related units and the fluvial deposits and paleosols of the overlying Crow Mountain Formation (Tohill, 1965; Tohill and Picard, 1966). The prevailing interpretations for depositional environments for the Goose Egg Formation, Red Peak Formation, and Alcova Formation have been marine or marginal marine environments. They have been interpreted as marine or marine-influenced based mostly on the laterally extensive nature of beds, the presence of gypsum and carbonate, and $\mathrm{Sr}^{87} / \mathrm{Sr}^{86}$ isotopes (Picard and High, 1963; Maughan, 1964; Picard, 1967; Storrs, 1991; Lovelace and Doebbert, 2015). However, marine interpretation is inconsistent with formation models for red beds (Walker, 1967b, 1967a, 1974; Houten 
and Franklyn, 1968; El-Baz, 1986; Retallack, 2008). Furthermore, the presence of gypsum and carbonates is not diagnostic of marine deposition, as both rock types may form in saline lakes, springs, soils, or be reworked as clastic grains (Hardie, 1970, 1984). This dissertation addresses this apparent contradiction between previous interpretations and modern analogs by conducting a detailed field and petrographic survey of Permian-Triassic red beds.

The Permian-Triassic rocks of Wyoming represent a gap in the understanding of central Pangean environments. Wyoming red beds appear to contain three unusual depositional environments reported from the Permian-Triassic: (1) atypical carbonates, phosphates, and silicates to the west (Stephens and Carroll, 1999; Hiatt and Budd, 2003; Matheson and Frank, 2020); (2) acid saline lakes and mudflats of the red beds and evaporites to the east and southeast (Andeskie et al., 2018; Benison et al., 1998; Benison and Goldstein, 2000, 2001); and (3) thick terrestrial alluvial, eo-

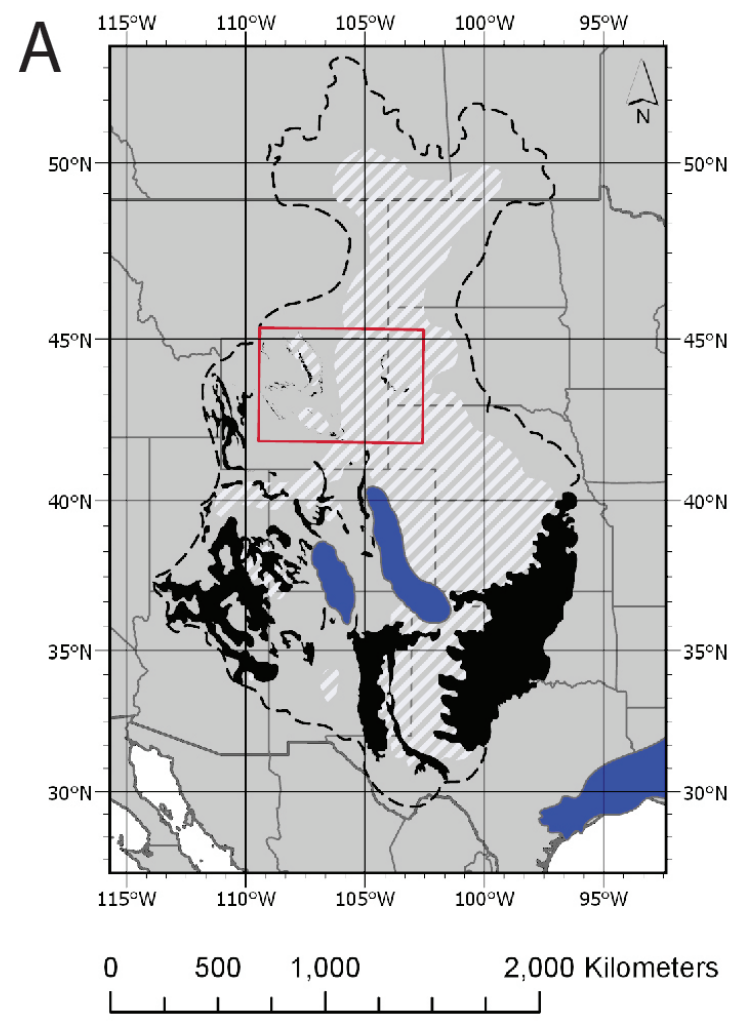

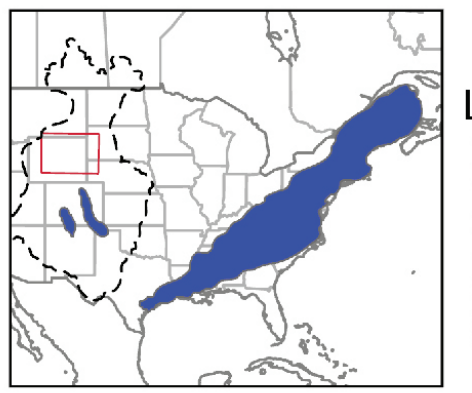

Legend
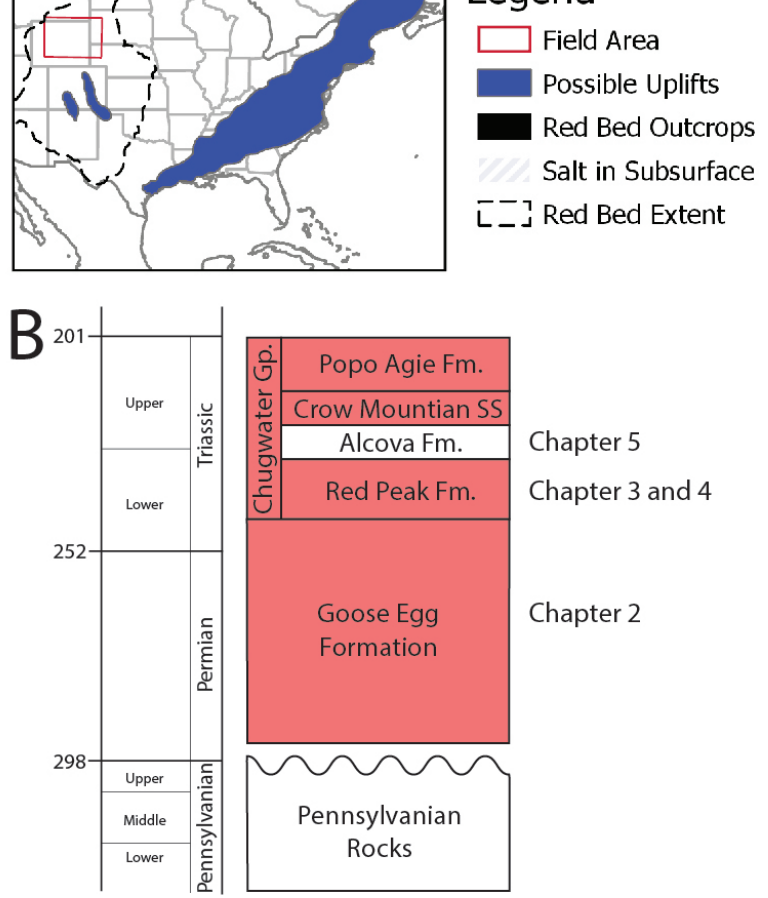

Chapter 5

Chapter 3 and 4

Chapter 2

Fig. 1: Location and stratigraphy of the greater Permian and Triassic red bed system in western North America. (A) Map showing the midcontinent of North America indicating surface or near-surface exposure of red beds (black area), the extent of salt in the subsurface (hashed area), possible uplifts, and source areas (blue area). (B) Map of outcrops used for this dissertation. The total extent of red beds on the surface is outlined with a dashed line. (C) Generalized stratigraphy of this study with chapters noted. Red beds are colored red. 
lian, and loess deposits to the south and southeast (Soreghan, 1992; Soreghan et al., 2002, 2008, 2014; Tramp et al., 2004; Sweet et al., 2013; Giles et al., 2013; Foster et al., 2014; Pike and Sweet, 2018). Some of these rocks record extreme environments, with lake waters and groundwaters pHs below 2, high salinity, and high concentrations of dissolved Al, $\mathrm{Si}$, and Fe (Benison et al., 1998; Benison and Goldstein, 2002). Also, these rocks attest to warm air temperatures (up to $74^{\circ} \mathrm{C}$ ), as well as a high diurnal temperature range and great aridity (Zambito and Benison, 2013).

This dissertation seeks to address the depositional environments, climatic context, and geographic extent of the rocks deposited during the Permian and Triassic global warming event in Wyoming. This dissertation's goals will be accomplished through: (1) a detailed field and petrological examination of three formations in central Wyoming to identify their depositional environment; and (2) construction of facies models and diagenetic history within the context of other red beds

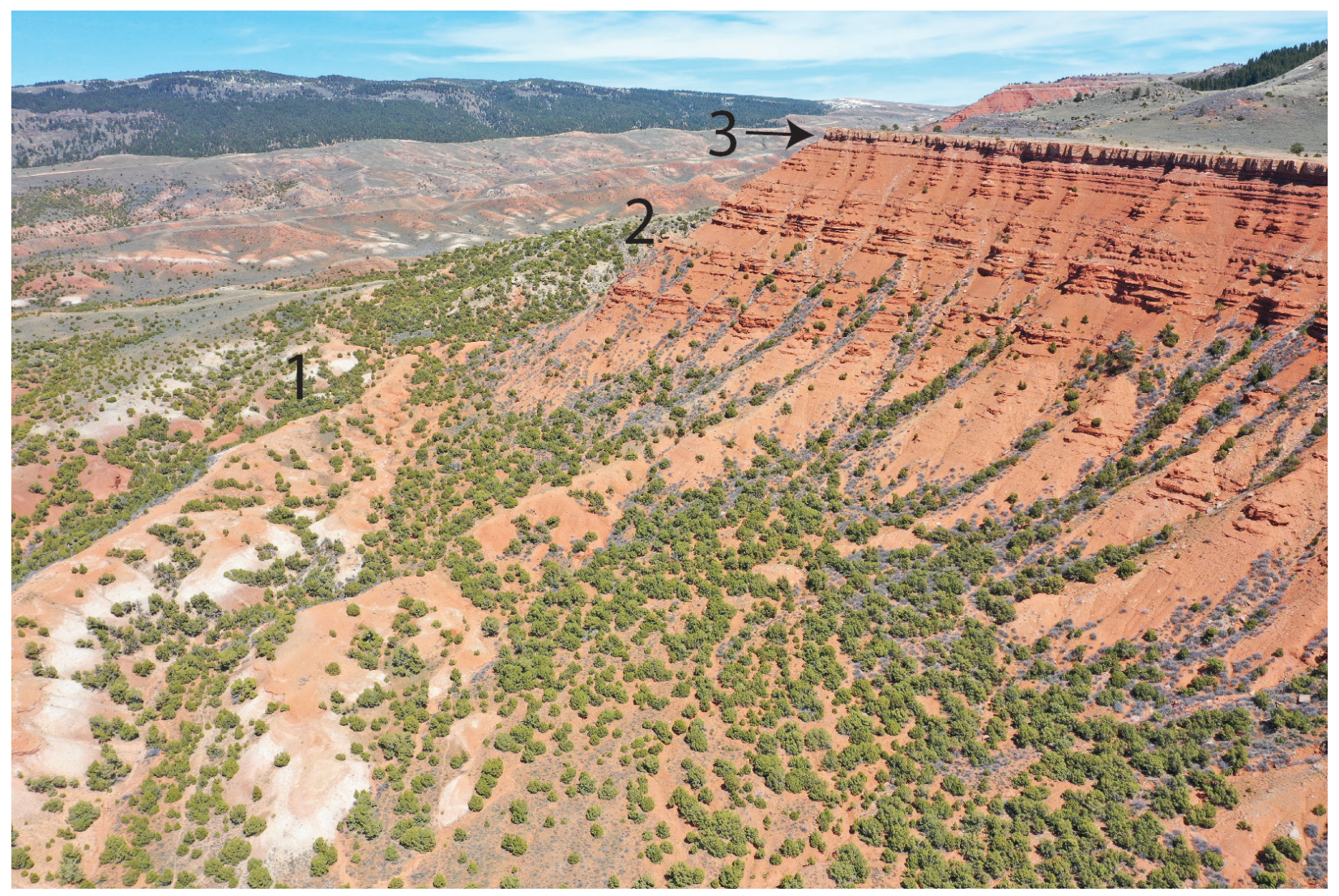

Fig. 2: Overview aerial photograph showing the Goose Egg Formation (1), the Red Peak Formation (2), and the Alcova Formation (3) at Casper Mountain near Casper, Wyoming, close to the type locality for the Goose Egg Formation. The height of this outcrop is approximately $95 \mathrm{~m}$ tall. 
and evaporites of Pangea. This study will resolve conflicts between previously proposed models for red bed formation and the previously proposed depositional environments of the red beds, carbonate, and gypsum of the Permo-Triassic of Wyoming. It will also contribute to an understanding of the Permian-Triassic environments, climate, and paleogeography.

\section{SCIENTIFIC AND SOCIAL IMPORTANCE}

Sedimentologists study the deep-time rock record to address important questions about the evolution of life, guide exploration for natural resources, and understand the range of environments on Earth and other rocky planets. This dissertation reconstructs depositional environments using details of sedimentary features, geochemistry, and fossils. The Permian and Triassic Periods have proven particularly important to study as an analog for a warming climate. However, the rocks of the Permo-Triassic has been difficult for geologists to understand because they vary widely from modern analogs. The Earth at the end of the Permian was widely different from modern experience, yet the uniformitarian-approach is still valid. Detailed sedimentological studies, like this one, are required to understand geological processes and their consequences during a global warming event, such as that at the end of the Permian.

The Permian-Triassic mass extinctions, extreme environments, and global warming is a Phanerozoic endmember for aridity, heat, and surface water chemistry. Red beds and evaporites are common Permian and Triassic rock types. However, outcrops of red beds and evaporites are difficult to study, and well-preserved cores are rare. This study will elucidate some of the physical, chemical, and biological processes during extremely arid environmental conditions. As modern global atmospheric $\mathrm{CO}_{2}$ increases, the rate of climate change is expected to increase (Solomon et al., 2007). The rapid and sustained increase in $\mathrm{CO}_{2}$ and its impact on earth systems is not a no-analog situation in human experience; however, the Permo-Triassic rocks record continental environments that have undergone this type of global climate change. The specific physical processes, geochemical products, and biological interactions with the environment may provide insight into the Earth's future.

This study also contextualizes the Goose Egg and Red Peak's highly arid environments within the context of the wider Permian-Triassic ecological system. These rocks are located adjacent to three extreme depositional systems identified as widespread at the time: (1) loess-dominated rocks, (2) acid saline systems, and (3) open marine systems with unusual chemistry. Wyoming's 
understudied rocks may hold the key to delineating the extent of extreme environments on the supercontinent and help constrain sediment transportation, habitability, and geochemical cycling within these systems.

Understanding the relationships between the marine rocks of western Wyoming and Utah with the continental rocks of South Dakota, North Dakota, and Kansas may greatly impact oil and gas exploration. The subsurface evaporites of the Goose Egg Formation are key elements in the local petroleum system, providing a seal for deeper units. A continental salt deposition model impacts the predictive framework for oil and gas exploration of Pennsylvanian rocks in the Powder River and Bighorn Basins. The succession's carbonate and gypsum units are often used as correlative strata and marker beds when drilling wells. This study provides a note of caution for attempts to correlate carbonate or evaporate units among red beds; continental depositional environments are unlikely to produce widely correlative units. However, non-correlative units may produce similar log signatures. The key insight is that the Permian-Triassic units may be inappropriate marker beds for landing horizontal wells and that the presence or absence of salt can greatly impact the thickness of the units.

\section{ORGANIZATION AND DISSEMINATION}

This dissertation is presented in six chapters: in this introductory chapter, four chapters focused on a formation or aspect of a formation and a conclusion. Chapters two through five are formatted as manuscripts for submission to peer-reviewed journals. The chapters are organized in chronological order of deposition, starting with the Permian Goose Egg Formation, then the Early Triassic Red Peak Formation, and finally, the Middle Triassic Alcova Limestone.

Chapter two of this dissertation is entitled "Saline Lakes and Loess in the Permian Midcontinent: Paleoenvironments of the Goose Egg Formation, Wyoming (USA)" and is focused on the depositional environments of the Goose Egg Formation. The GSA Bulletin has been chosen as the destination for this work. This work has implications for a global audience if interested in Permian and Triassic red beds. This manuscript uses detailed sedimentology and petrology to demonstrate that the Permian Goose Egg Formation was deposited in ephemeral lakes and associated continental environments on a wind-dominated, low-relief plain. This finding is significantly different

from the foundation work on the Goose Egg Formation from the 1930s and 1950s that postulated that the Goose Egg was primarily eastward tongues of the open marine rocks. 
Chapters three and four and will be submitted as paired manuscripts to the journal Sedimentology. Both manuscripts address aspects of the Red Peak Formation of the Chugwater Group. The Early Triassic Red Peak Formation is one of the most recognizable rock formations in the Rocky Mountains, yet remains poorly understood. It was recognized early as part of a continent-wide red beds system in the Permian and Triassic (Darton, 1906; Dorsey, 1926; Waugh, 1973). Most workers have interpreted this unit as deposited in a marine or restricted marine environment (Picard and High, 1963; Picard, 1967), with the red pigmentation being derived from deep burial diagenesis (Picard, 1965). However, this is inconsistent with modern thinking on red beds, recognized as formed in well-drained tropical (Walker, 1974) or desert (Walker, 1967b) soils. Together, these two manuscripts elucidate an aspect of the Permian and Triassic system relevant to the global audience of Sedimentology. Chapter three of this dissertation is entitled "The Permian-Triassic Red Beds of the Red Peak Formation, Wyoming (USA) Part I: Continental Ephemeral Lake Deposits, Loess, and Alluvium Modified by Pedogenesis," and addresses the sedimentology and environments of deposition of the Red Peak Formation of the Chugwater Group using detailed sedimentology, petrology, and scanning electron microscopy. This work demonstrates that the Red Peak Formation was deposited as part of a distal alluvial fan complex with contributions from lacustrine facies and a strong overprinting from pedogenesis. This work dispels a persistent myth that the Red Peak Formation was deposited in a shallow marine setting. These findings bring the Red Peak more closely into alignment with other red beds of the midcontinent.

Chapter four of this dissertation is entitled "The Permian-Triassic Red Beds of the Red Peak Formation, Wyoming (USA) Part II: The Origin of Red Pigment from Pre-Depositional and Pedogenic Processes," address in detail the origin of the red pigment in the Red Peak Formation. This dissertation identifies the sources of iron phases in the Red Peak using petrology and EDS elemental mapping in a scanning electron microscope and correlates iron oxide formation to the surface or near-surface processes that result in reddening. Among the finding are that thickly coated grains most likely originated in acid saline systems (Bowen et al., 2008) and were transported by the wind for deposition in the Red Peak Formation. This finding suggests that natural acid saline lacustrine systems (Benison et al., 2007) may be a newly recognized red bed forming environment, with long-range consequences due to sediments' wind distribution.

Chapter five focuses on the Alcova Limestone and is entitled "The Alcova Limestone: Saline Lacustrine Environments of the Triassic Chugwater Group, Wyoming (USA)." The Alcova Limestone is a distinctive Middle Triassic unit above the Red Peak Formation. The Alcova Lime- 
stone manuscript has been submitted to the Journal of Sedimentary Research and is currently in review. The Alcova Limestone is an example of a thin yet laterally persistent limestone within a thick succession of red beds. The Alcova Limestone is interpreted to have been deposited in a lacustrine environment, possibly originally as gypsum. The detailed analysis of the Alcova Limestone can provide insights for other thin carbonate units associated with red beds, particularly those of the Permian-Triassic.

This dissertation seeks perspective on the environments of deposition for Permian-Triassic rocks in Wyoming. These chapters define depositional environments for the Goose Egg Formation, the Red Peak Formation, and the Alcova Limestone. The evidence provided herein suggests that all three were deposited in inland continental depositional environments dominated by shallow saline lakes, windblown sediment, distal alluvial fans, and soil formation. 


\section{CHAPTER 2}

Title: Saline lakes and loess in the Permian: paleoenvironments of the Goose Egg Formation, Wyoming (USA)

Intended for Publication in: GSA Bulletin

Authors:

JONATHAN P. KNAPP ${ }^{1,2}$, KATHLEEN C. BENISON ${ }^{1}$

${ }^{1}$ Department of Geology and Geography, West Virginia University, Morgantown, West Virginia, U.S.A. 26506-6300

${ }^{2}$ Bruker Nano Analytics, Berlin, 12489, Germany;

Corresponding Author: Jonathan Knapp, Jonathan.Knapp@,bruker.com 


\section{INTRODUCTION}

From the mid-Permian through the mid-Triassic, red beds and evaporites dominated continental sedimentation in equatorial Pangea. These Permian-Triassic red beds are preserved today in the United Kingdom (Benton et al., 2002; Andeskie et al., 2018), Russia (Murchison, 1841), India (Chakraborty and Sarkar, 2005), France (Pfeifer et al., 2020), Brazil (Bell, 1989; Abrantes et al., 2016), and over much of the midcontinent of the United States and Canada (Mudge, 1872; Darton, 1908; Tomlinson, 1916; Branson, 1927; Baars, 1961). Extremely acid saline lakes and groundwaters have been interpreted from Permian-Triassic red beds and evaporites from Kansas, North Dakota, and Northern Ireland (Benison et al., 1998, 2014; Benison and Goldstein, 2000, 2002; Andeskie et al., 2018). Many late Paleozoic red beds of western Pangea have been attributed to significant accumulation of loess, or continental wind-blown silt-sized or smaller sediment and subsequent pedogenesis (Soreghan et al., 2008a; Sweet et al., 2013; Foster et al., 2014).

The Goose Egg Formation of central and eastern Wyoming lies between the marine Phosphoria Formation to the west and the continental ephemeral acid saline lakes and red mudflat deposits of the Opeche Shale and the Nippewalla Group to the east and southeast, respectively (Sheldon, 1955; Burk et al., 1956; Benison and Goldstein, 2000, 2001; Matheson and Frank, 2020). The Goose Egg Formation occupies a critical geographic position between continental deposits in the midcontinent and marine rocks in western Wyoming.

The Goose Egg Formation has previously been interpreted as a marginal marine or lagoon deposit. It has been considered transitional between the marine Phosphoria Formation and related Park City Formation and Dinwoody Formation and the continental rocks of the Opeche Shale (Thomas, 1934; Burk et al., 1956; Maughan, 1964, 1993; Lane, 1973). Thomas (1934) concluded that the red beds must have been deposited in a "special marine environment" to preserve the red color. Marine interpretations for the Goose Egg Formation red beds were based on their close association with gypsum and carbonate and their lateral continuity (Thomas, 1934; Burk et al., 1956; Maughan, 1964, 1993). Peterson (1984) linked Goose Egg Formation carbonates to transgressive-regressive eustatic cycles connected to the Phosphoria Formation and suggested that some of the red beds could have been deposited during a relative sea-level regression.

Considering recent scholarship, genetically linking carbonates, evaporites, and red beds of the Goose Egg Formation to eustatic sea-level change is a suspect interpretation. Lane (1973) demonstrated that the Goose Egg rocks do not correlate to the marine units of the Phosphoria. Studies of modern red beds have shown that they form from a diverse range of continental environments. Red beds form in tropical latitudes and by early diagenesis and pedogenesis in arid and hot and humid climates (Walker, 1967b, 1967a, 1974). Reddening of grains may occur from 
grain-to-grain impacts in the presence of red dust during eolian transportation (El-Baz, 1978, 1986). Red grain-coating iron oxide cement and concretions and other red authigenic chemical precipitates form in acid lake water and groundwater (Blowes et al., 2003; Benison et al., 2007; Bowen et al., 2008; Schindler and Hochella, 2015). Carbonates and evaporites commonly form in lacustrine environments (Hardie, 1984; Lowenstein and Hardie, 1985; Last, 1990; Hardie et al., 2009). The Goose Egg Formation's red beds, evaporites, and carbonates could be continental. This study uses detailed sedimentological observations to resolve the deposition of the Goose Egg Formation and ascertain if they are continental. Further, this may illuminate their relationship to the continental Opeche Shale to the east marine rocks, including the Phosphoria Formation, to the west.

\section{METHODS}

This study is based on fieldwork conducted in Wyoming (Fig. 1) in 2013, 2017, and the winter of 2019-2020. Before site visits, aerial reconnaissance (Fig. 2) and photography were conducted with a DGI Mavic 2 autonomous quadcopter equipped with a Hasselblad L1D-20c camera with a 1" CMOS detector capable of 20-megapixel resolution. Field photos were captured with
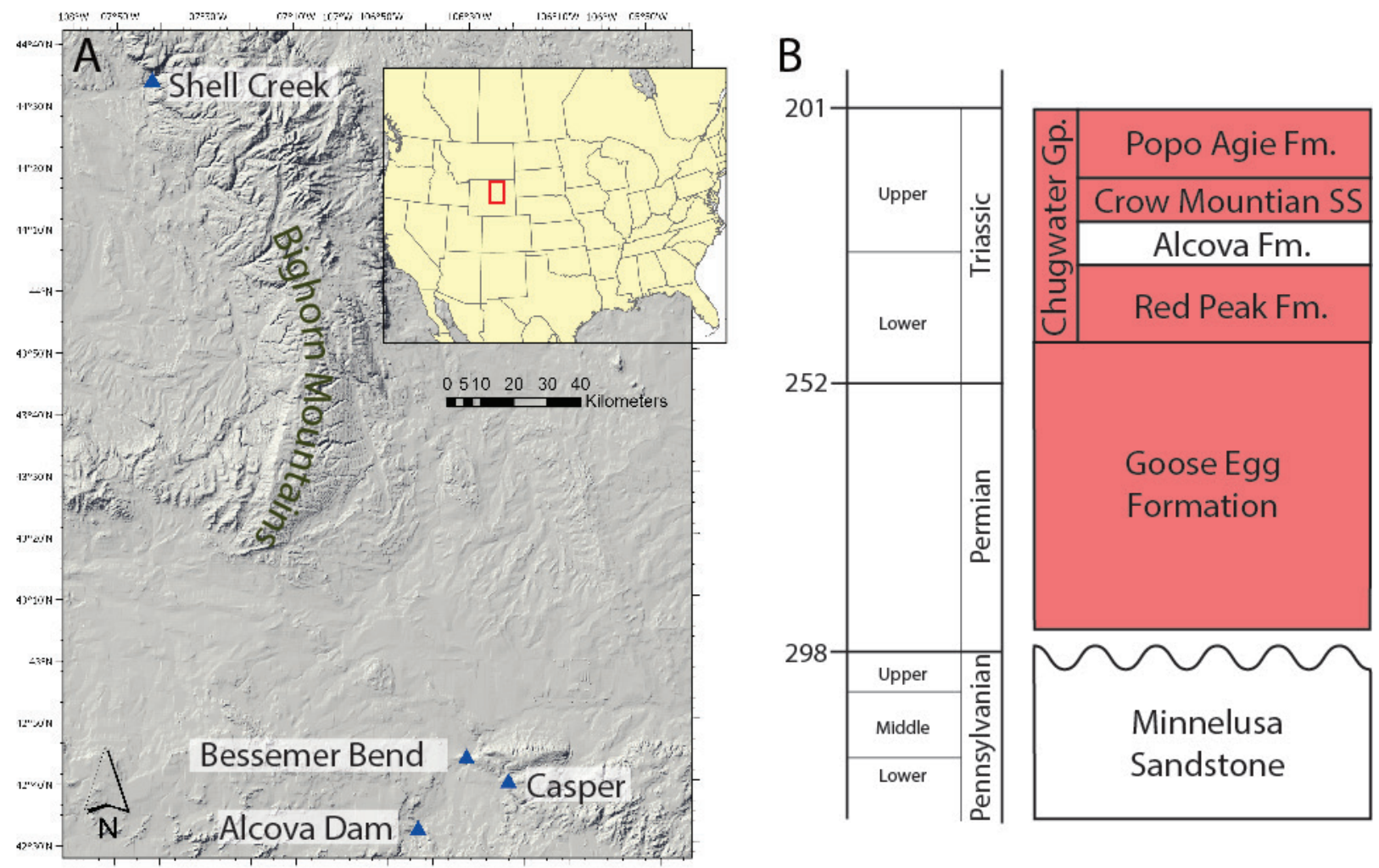

Fig. 1: Location and stratigraphic nomenclature. (A) Map of the study area with locations referenced in the text. (B) Generalized stratigraphic nomenclature. Red beds are highlighted in red. 
a Canon 80D with an EFS $18 \mathrm{~mm}$ to $135 \mathrm{~mm}$ lens for medium distance and an EFS $60 \mathrm{~mm}$ fixed macro lens. Centimeter-scale measured sections were measured at Bessemer Bend near Casper and at the Alcova Dam, based on sedimentary textures, sedimentary structures, lithological compositions and colors, and reaction $\mathrm{HCl}$, sedimentary body geometries, trace fossils, fossils, and other sedimentary features used to make stratigraphic columns. Representative rock samples were collected, and 12 large ( 2 x 3 in) thin sections were made for petrographic study. Observations and digital photomicrographs were made with transmitted, reflected, and polarized light sources on an Olympus SZX12 binocular microscope capable of 6.3 - 63 x magnification and an Olympus BX51 petrographic microscope capable of 20 - 2,000 x magnification. Mineralogy was confirmed on three samples with a PANalytical X'pert Pro $\mathrm{Cu}$ anode $\mathrm{X}$-ray diffractometer (XRD). Powder samples were measured for 60 seconds per degree between 10 and 90 degrees. Powder XRD analyses did not distinguish clay minerals quantitatively.

\section{RESULTS}

Based on field, petrographic, and mineralogical observations, the Goose Egg Formation has been divided into seven lithofacies: (1) massive to blocky red mudstone, (2) laminated mudstone, (3) lenses of fine sandstone and siltstone, (4) conglomerate lithofacies, (5) laminated carbonate mudstone, (6) bedded carbonate mudstone, and (7) bedded gypsum. This section is organized with descriptions, followed by an interpretation for each lithofacies. Lithofacies are ordered from older to younger.

The massive red mudstone lithofacies, laminated mudstone lithofacies, and fine sandstone and siltstone lenses lithofacies are rarely well exposed, forming grassy hillslopes or featureless red mounds (e.g., Fig. 2C). These three lithofacies can only be effectively identified in the rare places where a recent stream or road cuts have exposed them. Because they cannot be consistently differentiated at the surface, they are grouped as single units (Fig. 3).

The Goose Egg Formation's carbonate lithofacies is a minor constituent compared to the red sandy siltstone lithofacies or the bedded gypsum lithofacies. However, the carbonates are resistant and thus better exposed. Additionally, approximately $0.5 \mathrm{~m}$ to $2 \mathrm{~m}$ of red beds below carbonate beds are bleached. The bleaching makes the carbonate units stand out and appear to a casual observer thicker than they are. However, close inspection and acid tests show that the carbonate units are thin $(>4 \mathrm{~m})$, though they are laterally extensive. The lowermost carbonate lithofacies unit at the Alcova Dam (Fig. 2E) can be walked out for $9 \mathrm{~km}$ and may extend much farther. In 

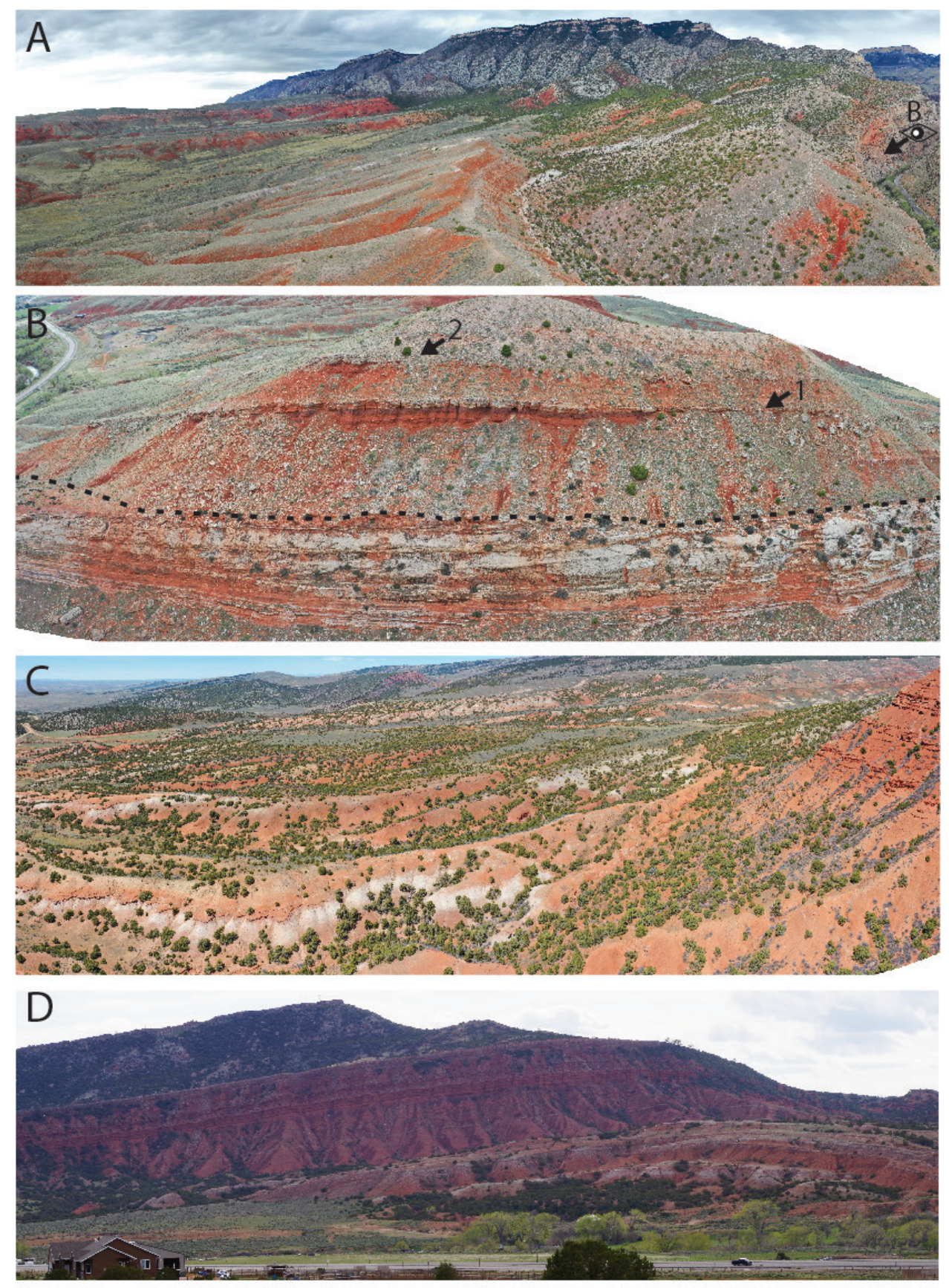

E

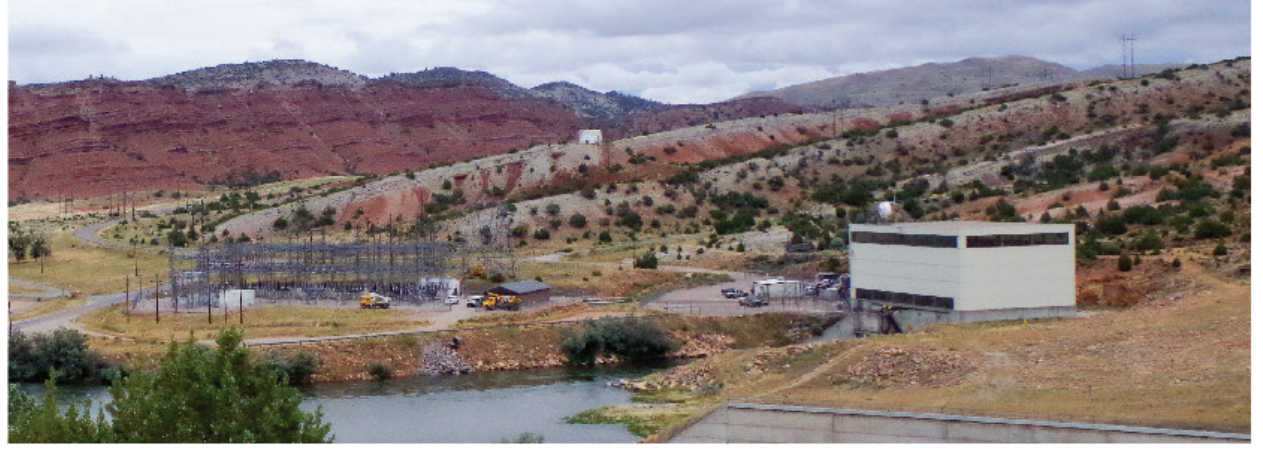


Fig. 2: Airborn imagery of the Goose Egg Formation. (A) The Goose Egg Formation at the entrance to Shell Canyon. The "stairstep" pattern of erosion is typical for the Goose Egg Formation. The Goose Egg Formation often forms grassy eroded slopes. Note arrow indicating the orientation of the next photomosaic. (B) Photomosaic showing the contact between the Minnalusa Sandstone and the Goose Egg at Shell Canyon. The contact (dashed line) is an unconformable contact with up to 3 meters of erosion into the Minnalusa. The slope-forming nature of the Goose Egg Formation can be seen. Thin carbonates (point 1) make up a small proportion of the overall unit. Some thin carbonates (point 2) pinch out. (C) The Goose Egg Formation at Casper Mountain showing the eroded badlands typography and stairstep pattern typical of the Goose Egg Formation. The contact between the overlying Red Peak Formation is a gradual change in the red pigment, with no distinct boundary. (D) The Goose Egg Formation and Red Peak Formation at Bessemer Bend outside of Casper, Wyoming. The drone that took this photo was launched from around the Goose Egg Inn, the type locality of the Goose Egg. (E) The Goose Egg Formation exposed at the Alcova Dam with the characteristic stairstep erosion pattern and covered topography. A measured section was enabled along the road leading from the generator house (white building) to the dam (photo origination point).

contrast, the uppermost carbonate lithofacies unit at Alcova Dam pitches out after $3 \mathrm{~km}$. At Shell, the lowermost carbonate lithofacies unit could be traced in an outcrop for only $1.5 \mathrm{~km}$ until it pinched out (Fig. 2A).

\section{Massive to Blocky Red Mudstone Lithofacies}

\section{Description}

The massive to blocky red mudstone lithofacies is the most common lithology in the Goose Egg Formation. It consists of dark red (10R 4/6) to reddish-orange (7.5 YR 5/8) bimodal fine sandy siltstones or well-sorted siltstone (Fig. 4). Grains are sub-angular to sub-rounded, highly spherical (0.9) fine to very-fine upper sand in a well-packed, angular to sub-angular, moderately spherical (0.7) siltstone (Fig. 4). In order of abundance, grains are quartz, gypsum, feldspars, and micas. Quartz and gypsum grains are as large as sub-angular medium sand. Feldspars and micas are smaller than quartz and gypsum. Sand is either evenly distributed as isolated grains in the silt or is concentrated in blobs or lamina with point grain contacts (Fig. 4A, no. 2). Amid the silt and quartz, sand grains are abundant detrital intraformational mud clasts, which likely originated as pedogenic mud aggregates (Fig. 4E, arrows). Pedogenic mud aggregates are elongated, 0.3 to 0.6

mm long (medium to coarse sand), and oriented parallel to bedding. Aggregates are more opaque in transmitted light than the rest of the matrix, with few discernable silt-sized grains. 


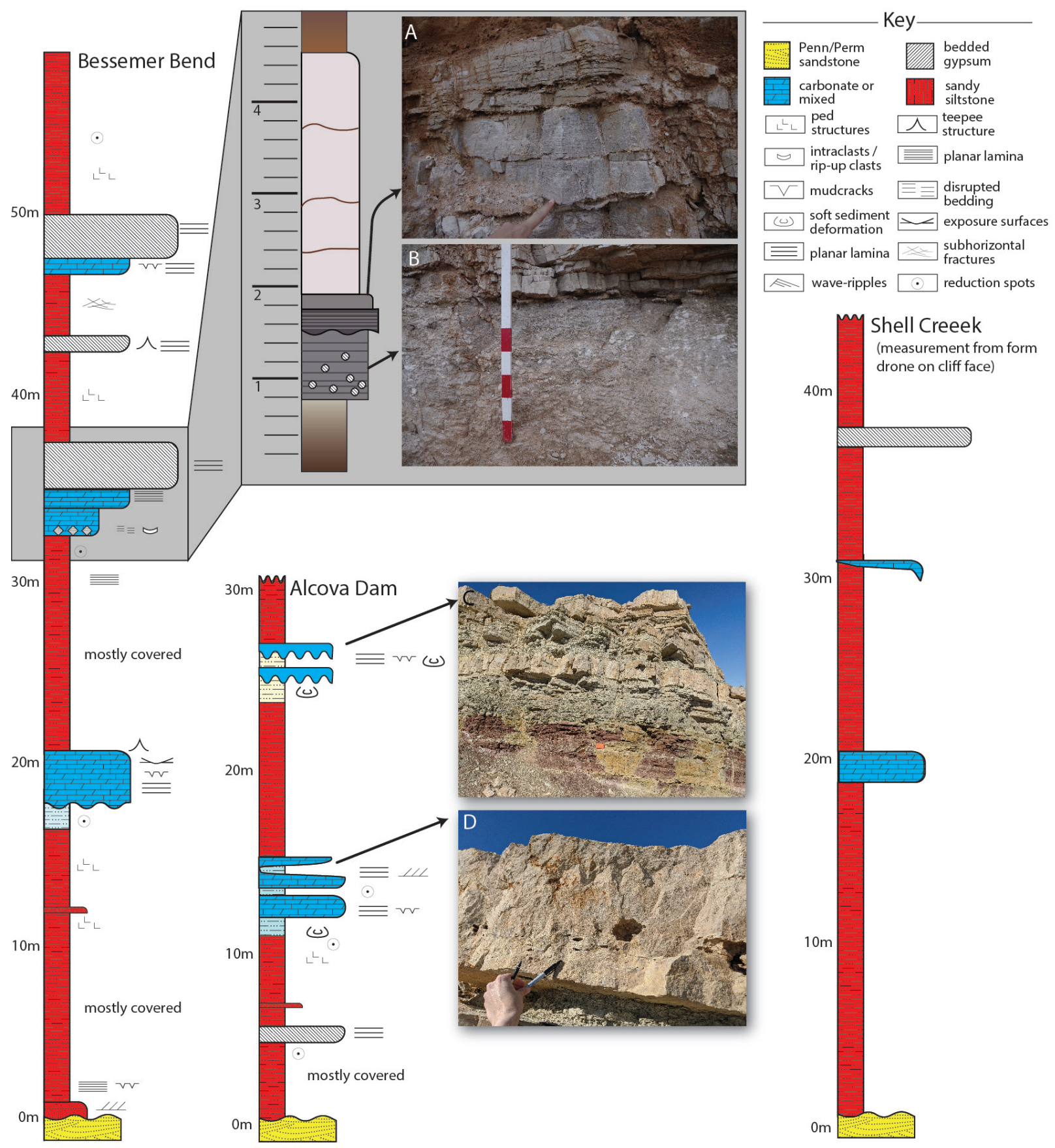

Fig. 3: Simplified stratigraphic sections from Bessemer Bend, Alcova Dam, and Shell Creek illustrating lithofacies, sedimentary structures, and select details from sections. 
Sedimentary structures include rare disturbed or chaotic laminations (Fig. 4A, no. 1; 4C), large blocky peds, small blocky peds (Fig. 7A, C), and possible bioturbation (Fig. 4C, no.1). There are rare indentations and raised sub-cubic shapes with $90^{\circ}$ angles in red mudstone float. Blocky peds are either small (Fig. 7C, no. 4) or large (Fig. 7C, no. 5) with rounded edges. Small peds are typically smaller than $2 \mathrm{~cm}$ across with distinct clay skins and form thin beds or horizons between $30 \mathrm{~cm}$ and $90 \mathrm{~cm}$ thick that are laterally continuous across the outcrop. Larger peds are typically more than $4 \mathrm{~cm}$ across and definitive in-filling between peds of either finer or coarser sediment. Commonly, larger peds are in patches up to $120 \mathrm{~cm}$ at the thickest point and pinch out within a few meters.

The massive to blocky red mudstone lithofacies is commonly cross-cut by sub-horizontal $1 \mathrm{~mm}$ to $2 \mathrm{~mm}$ thick gypsum-filled veins (Fig. 7A, no. 3). Diffuse light greenish-grey (GLAY 8/10Y) coloration defines reduction layers and reduction spots. Dark greenish grey (GLEY 7/10GY) reduction spots are common, often with dark centers. Units are often poorly cemented and friable. Many outcrops have an indistinct "rubble" appearance, with chunks of outcrop that can be easily crushed to dust between the fingers (Fig. 7E).

\section{Interpretation}

The massive to blocky red mudstone lithofacies are interpreted to have been deposited on an alluvial plain. It is difficult to have much more specificity, but the lack of channelization, sedimentary structures, fossils, and ubiquitous fine grain size support deposition in a low-relief, low-energy environment. The term alluvial plane refers to the mostly-flat constructional landscape comprised of units of different ages and deposited in different environments, typically associated with meandering rivers and the associated interfluvial. The Goose Egg Formation has no large fluvial system, so this term includes the low-relief basinward sediment sink of a large closed basin with possible sub-environments that could include lakes, loess plains, and sandflats, mudflats, and terminal splays of alluvial fans. In inter-lacustrine areas, the reworking of sediment by wind, the overland flow of water, or pedogenesis is likely.

Well sorted and chemically immature fine to medium silt with little clay-sized grains is consistent with long-distance transportation by wind and deposition as loess (Tsoar and Pye, 1987; Sun, 2002). The bimodal grain size of silt and fine sand can result from either strongly divergent seasonal directionality or as lags from deflation in strong wind (Rogers, 1958; Ahlbrandt and Fryberger, 1981; Fryberger, 1990). Transported pedogenic mud aggregates were likely mud and silt-mud pellets transported as bedload in unconfined overland flow (Rust and Nanson, 1989; Ekes, 1993; Muller et al., 2004; Gierlowski Kordesch and Gibling, 2012). Taken together, this 
could indicate deposition and reworking by both wind and overland water flow.

The sub-cubic shapes with $90^{\circ}$ angles are casts of dissolved halite. The indistinct rubble and poorly cemented featureless siltstone are consistent with salt-bearing units' subsurface halite that has been dissolved at the surface (Benison et al., 2015). Halite and halite dissolution has been documented on down-hole logs from the Goose Egg Formation (Faulkner, 1956; Maughan, 1966; Parker, 1967; Rasmussen and Bean, 1983). Bedded evaporites interbedded with red mudstone, displacive crystals of evaporites, and intergranular saline cement can for in and around saline pans or small saline lakes (Hardie, 1984; Lowenstein and Hardie, 1985).

The blocky peds, backfilled burrows, and bioturbation or disturbed bedding is the result of pedogenesis. Pedogenesis is patchy with few well-formed horizons. There is no evidence of accumulations of soil carbonates, gypsum, slickensides, or other indications of well-formed soils. That few well-developed soils form supports constant reworking by wind or unconfined flow or frequent flooding. However, landscapes must have been subaerially exposed and somewhat stable for any soil to form.

\section{Laminated Siliciclastic Mudstone Lithofacies}

\section{Description}

The laminated siliciclastic mudstone lithofacies consists of laminated to thinly bedded siltstones and claystone in units up to $2 \mathrm{~m}$ thick. Silt grains are fine silt to medium silt with rare coarse silt, and very rare vary fine lower sand (Fig. 5). Grains are rounded to sub-rounded quartz and gypsum, with sub-rounded to angular feldspar, muscovite, biotite, and lithic fragments. Sphericity of silt grains, excluding micas, ranges from highly spherical (0.9) to moderately spherical (0.7). The laminated siliciclastic mudstone lithofacies is often exposed directly below or interbedded with resistant carbonate beds where it has been bleached to a light greenish-grey (GLAY 8/10GY).

Laminae are commonly defined by (1) alternating bands of red (iron-oxide containing) and nonred intragranular cement in well-sorted siltstone (Fig. 5A); (2) graded siltstone beds in a claystone matrix (Fig. 5B); or (3) micro-laminated claystone interbedded with thicker siltstone units with red intergranular cement. Beds with alternating red and non-red intergranular cement also have more intergranular cement and slightly smaller grain size in red bands. Red laminations also commonly have muddy red clasts or mud aggregates less than $150 \mu \mathrm{m}$ across (Fig. 5F). 

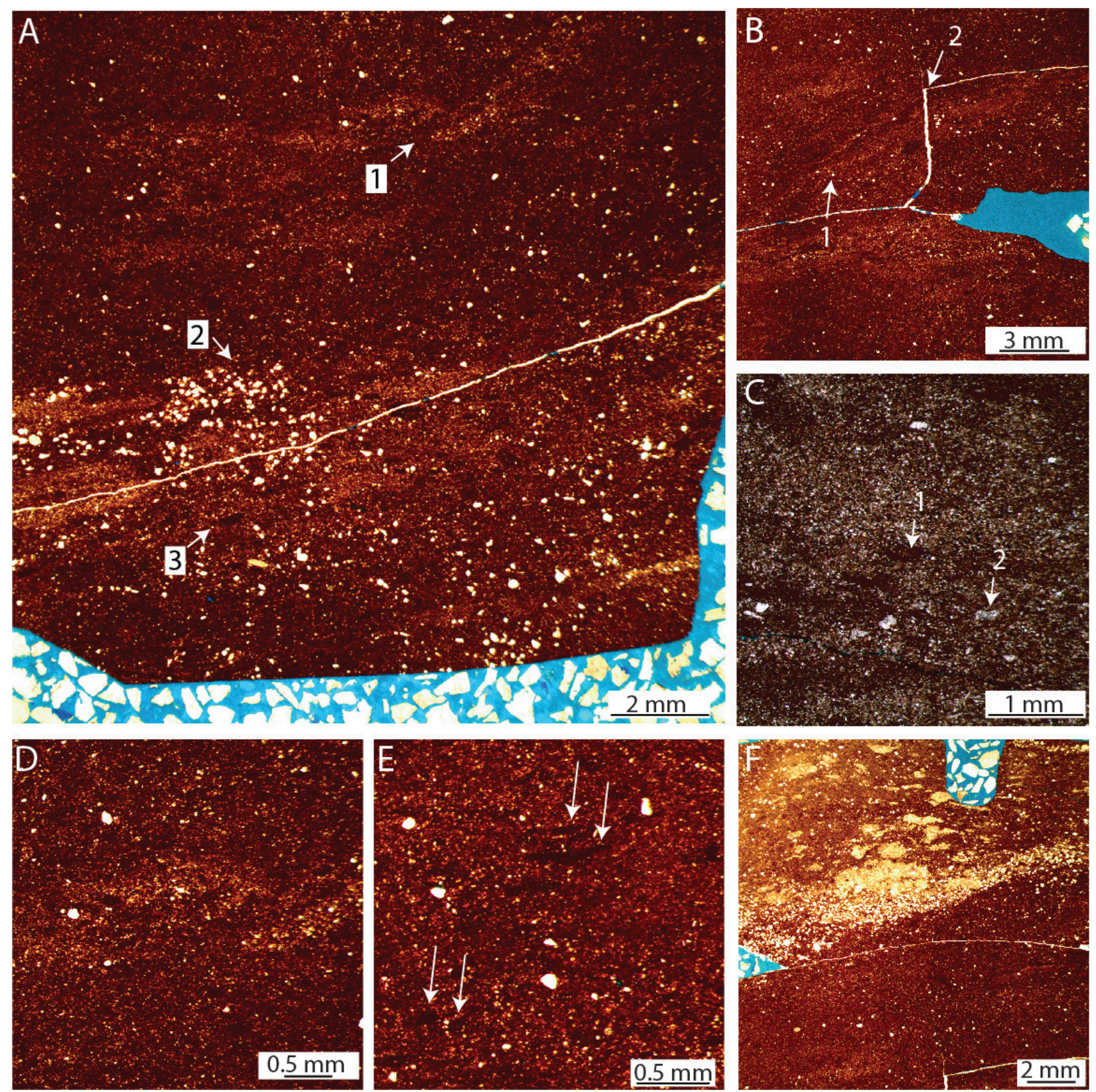

Fig. 4: Photomicrographs of massive beds of sandy siltstone. (A) Typical massive bed of sandy siltstone photomicrograph showing disrupted laminations (no. 1) and bimodal quartz zones (no. 2) in a fine silt groundmass. Pedogenic mud aggregates oriented with bedding are darker than the rest of the groundmass (no. 3). (B) Soft-sediment deformation (no. 1) and cracking (no. 2). (C) A silt-sized groundmass with lammana is defined by increased amounts of the iron-rich matrix (no.1) and recrystallized large gypsum grains (no.2). (D) Bimodal grain size with large gypsum grains. (E) Detail of pedogenic mud aggregates (arrows) in a fine siltstone groundmass suspending sub-rounded quartz grains. (F) Reduction spots and a san-sized lammana in siltstone. 

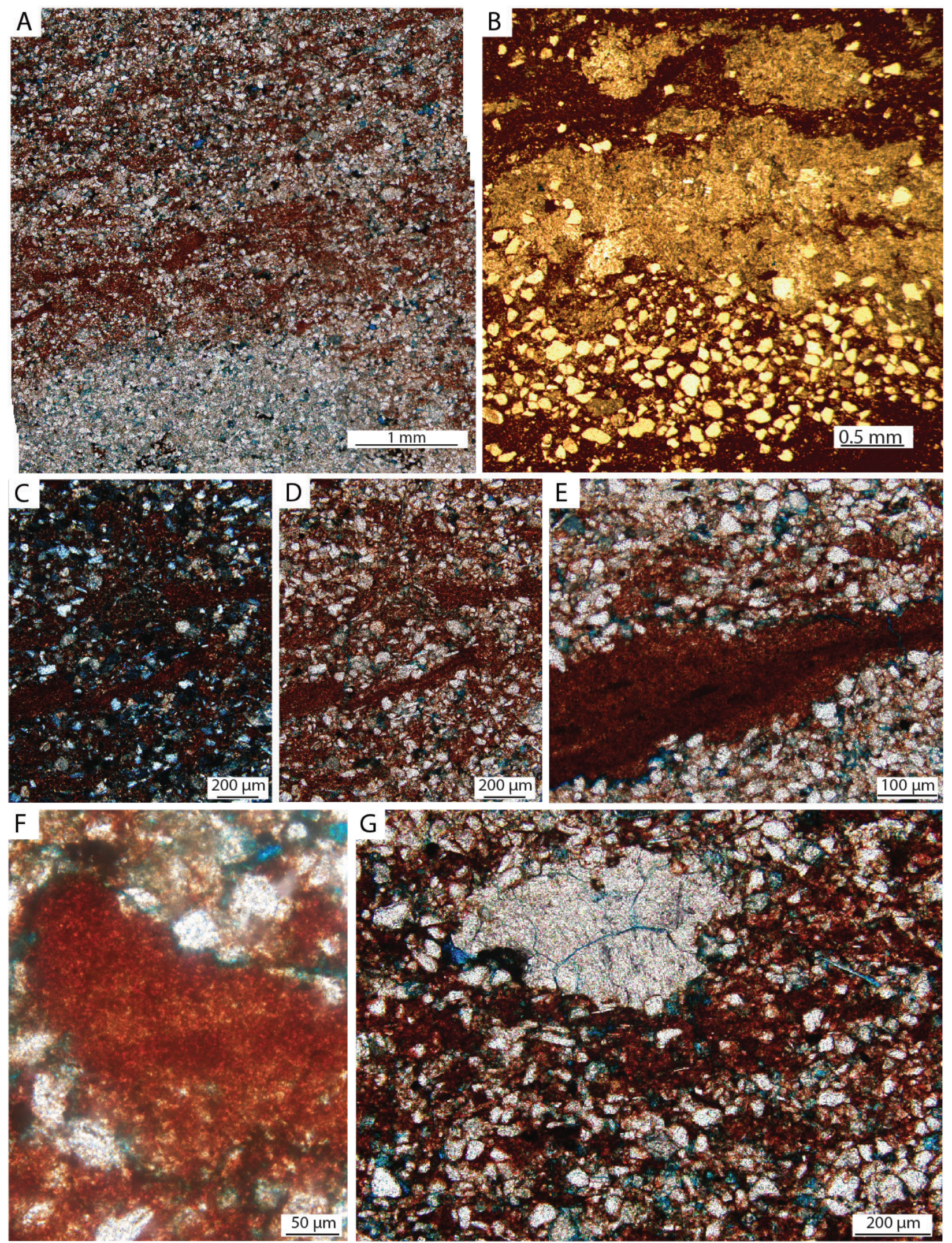
Fig. 5: Photomicrographs of Laminated Red Siltstone. (A) Mosaic image of laminated alternating red and drab siltstone. The red color is controlled by the amount of red cement between detrital grains. (B) Graded bedding with sub-rounded quartz in a siltstone groundmass. Groundmass has extensive bleaching. (C) Cross polarized and (D) plane-polarized light of a mud-rich lammana. Silt-sized sub-rounded to sub-angular grains is quartz, feldspars, and micas. (E) Detail of mud-rich lammana showing micro-lamination. Surrounding siltstone has linear grain contacts, likely from compaction. A thin red cement surrounds all grains. (F) Detail of mud aggregate in a red lamina. $(G)$ Blocky pore-filling calcite cement.

Units are of two types: (1) laminated siltstones and (2) alternating siltstones and claystones. Laminated siltstones are units up to $1 \mathrm{~m}$ thick consisting of alternating 1 to $2 \mathrm{~mm}$ thick laterally continuous red (10R 6/4) and greenish-grey (GLAY 7/5G) siltstone lamina. Alternating siltstones and claystones units up to $2 \mathrm{~m}$ thick of alternating bedsets of red (10R 6/4) or grey (GLAY $7 / 5 \mathrm{G}$ ) claystone lamina up to $2 \mathrm{~mm}$ thick with tannish orange (5YR 5/7 to 5/8) siltstone laminae and beds up to $15 \mathrm{~mm}$ thick. Most laminae are laterally extensive and parallel. Some claystone laminae pinch and swell or pinch out. Laminae have sharp bases and usually have sharp tops, but some siltstone lamina and thin beds have gradational tops (Fig. 5B). Rarely, the laminae are deformed by soft-sediment deformation (load casts or small-scale dish structures) below other lithofacies units. Blocky calcite cement is common (Fig. 5G).

\section{Interpretation}

The laminated siliciclastic mudstone lithofacies is interpreted to have been deposited in quiescent subaqueous environments. Millimeter scale fine-grained continuous laminations of siltstone and mudstone with sharp tops and bases are consistent with suspension settling. Millimeter to centimeter-scale siltstone units with sharp bases and gradational tops are consistent with deposition from sediment deposited from waning flow in turbid flow events. Turbid flow events in this content include high-velocity unidirectional flow capable of holding sediment in suspensions such as hyperpycnal flows and sediment gravity flows. Turbid flow events capable of carrying a suspended load can occur from overbank flow in fluvial systems and from "flash flooding" events in alluvial overland unconfined flow (North and Davidson, 2012). Hyperpycnal flow can occur where there is a density or temperature difference between inflow water and the lake or ocean. Turbidity currents or sediment gravity flows can occur from slope failure and carry sediment down slopes where it is deposited after slope breaks. Both hyperpycnal flows and sediment gravity deposits, although more widely known from marine settings, are common in lacustrine settings (Gierlowski-Kordesch, 2010; Zavala et al., 2011; Olariu et al., 2012). In all turbid flow events, high-velocity turbid flow can entrain sediment causing small-scale erosion. When velocities decrease, either from waning flow or decelerating flow, sediment comes out of suspensions and deposits as a gradational bed. The regular recurrence of events results in lamination. 

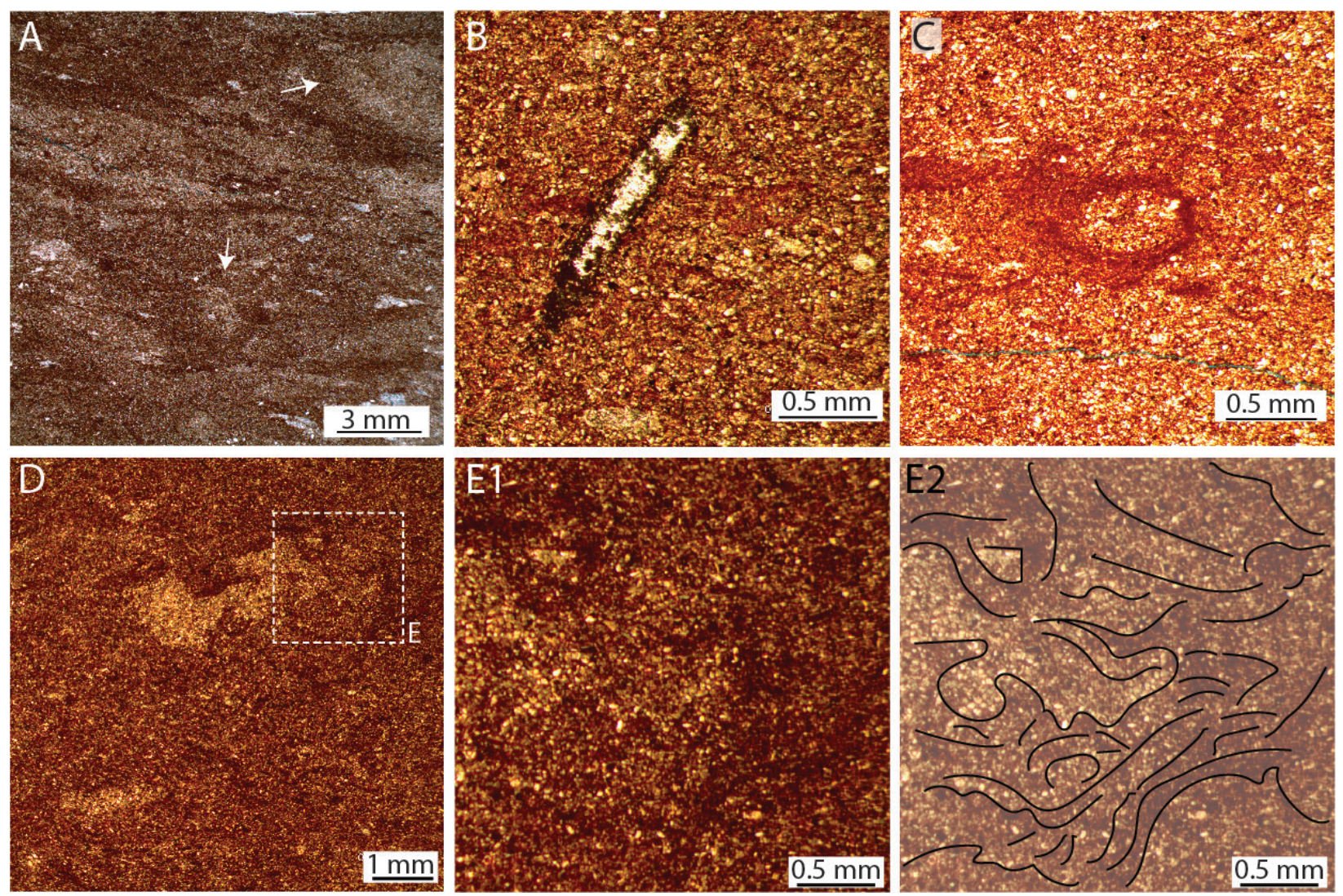

Fig. 6: Photomicrograph from thin siltstone and sandstone lenses: (A) chaotic bedding with courser siltstone pockets (arrows), and some recrystallization. (B) Root trace in red siltstone. (C) Laminated clay skin surrounding a root trace in red sandy siltstone. (D) Overview and (E1) detail of red sandy siltstone with chaotic bedding (E2). Grain size difference defines vague and convolute bedding. Patches of course silt and sand have angular boundaries adjacent to the clay-sized matrix. This feature could be shrink-swell features with siltstone infiltration or, more likely, the remnants of efflorescent crusts.

Preservation of laminated deposits requires an absence of bioturbation or other reworking mechanisms. Laminated sediment is often preserved where bioturbation is limited by water chemistry, temperature, or lack of light. For example, conditions favorable for preserving laminations are common in the profundal zone of large fresh and perennial saline lakes and across much of the subaqueous bottom of stratified lakes and saline lakes (Gierlowski-Kordesch, 2010). Laminated deposits from suspension settling and turbidity currents can occur and be preserved in unconfined flow events, overbank flooding of fluvial systems, during flooding stages of ephemeral saline lakes, or in perennial lakes. The preservation of lamination from unconfined flow events is possible when the frequency of flooding events and sediment accumulation exceeds bioturbation or wind reworking ability to obfuscate the gradational beddings. However, there is no evidence of exposure in pedogenic overprinting or mud cracks, or reworking by the wind. Deposits in fluvial overbank deposits are also unlikely, as there is no evidence of any other fluvial features such 
as levee deposits, channel sands, latter accretion, or channel abandonment mudstones. Preserved gradational bedding without evidence of exposure, claystone with preserved microlamination, and laterally continuous lamina are most consistent with deposition during the flooding stage of an ephemeral lake or in a perennial lake.

The alternations in grain size that distinguish the laminations are likely associated with periodic flooding that introduces more silt-sized sediment into the lake or dust-storm events that introduce abundant wind-blown sediment. A seasonal component is possible, but periodic storm events are also likely. The dominance of well-sorted silt-sized chemically immature sediment suggests wind-blown sediment transport (Tsoar and Pye, 1987). Lakes can trap atmospheric dust directly or have previously deposited sediment washed in by flooding, resulting in well-sorted siltstone lamina or verves of siltstone and mudstone (Breuning-Madsen and Awadzi, 2005; Washington et al., 2006; Chu et al., 2009).

The presence of sub-rounded detrital grains of gypsum is significant, suggesting contemporaneous wind-blown or water-eroded gypsum. Modern examples of wind-blown sand- or silt-sized gypsum are close to their source $(<50 \mathrm{~km})$, most commonly ephemeral lakes (Benison et al., 2007; Benison, 2019). Gypsum sand and silt may also have been eroded from adjacent older ephemeral lake deposits (Kocurek et al., 2007; Benison et al., 2007; Langford et al., 2009; Jerolmack et al., 2011).

\section{Fine Sandstone and Siltstone and Lenses Lithofacies}

\section{Description}

The fine sandstone and siltstone lenses lithofacies are single beds of dark red (10R 4/6) to reddish-orange (7.5 YR 5/8) resistant beds of siltstone or very fine sandstone (Fig. 7A, no. 1). Beds are isolated within either the massive to blocky red mudstone lithofacies or the laminated siliciclastic mudstone lithofacies. Beds form two distinct lithologies, (1) continuous massive siltstone beds with sharp upper and lower contacts, and (2) thin beds of siltstone and fine sandstone with sedimentary structures that pinch out.

Continuous massive siltstone beds with sharp upper and lower contacts only occur within the massive to blocky red mudstone lithofacies. The most commonly occur as resistant beds protruding from the red rubble and soil in well-eroded hillslopes. Beds are laterally continuous for meters or more and are 10 to $20 \mathrm{~cm}$ thick single beds (Fig. 7A, no. 1). Grains are well-sorted sub-angular to sub-rounded highly spherical coarse siltstone with patches of very fine lower 

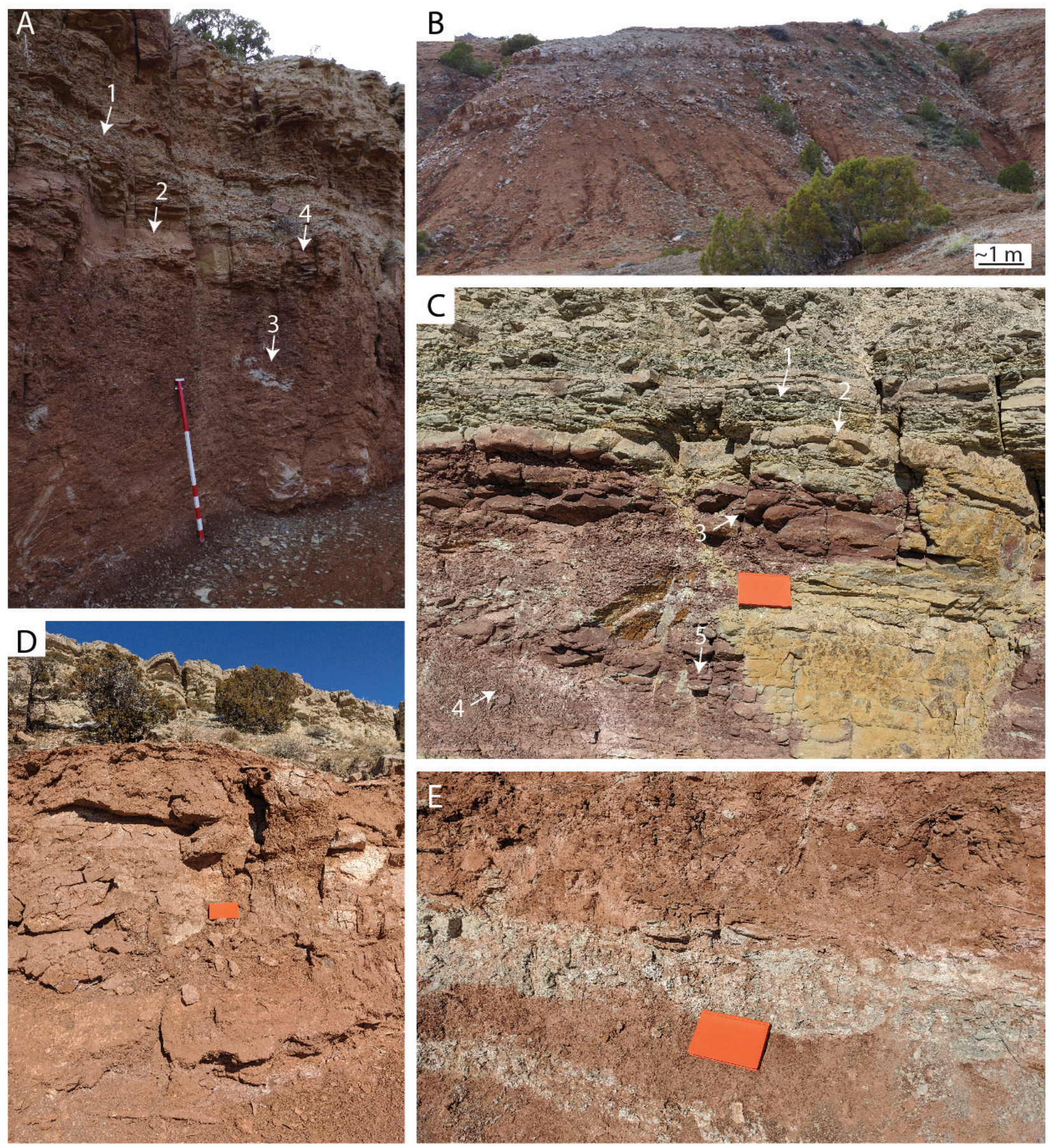

Fig. 7: Red silty sandstone in outcrop. (A) Stream cut exposure providing the most comprehensive view of sedimentary features in the field area. Laminated siltstone with alternating red and drab silt and mud lammana (no. 1) overlies and drape onto a courser sandy siltstone lense (no. 2) within featureless red sandy siltstone (no. 3). The sandy siltstone lenses pinch out (no. 4) and are overprinted with round blocky peds. (B) The sandy siltstone weathers to featureless red hillsides. A thick gypsum unit caps this photo from the Bessemer Bend locality. (C) Detail of bleached area directly below the first carbonate unit at the Bessemer Bend locality with laminated units (no. 1), siltstone lenses (no. 2), pillow structures and weak soft-sediment deformation 
(no. 3), and featureless sandy siltstone (no. 4) with blocky overprinting (no.5). (D) Gypsum units can be hard to recognize in the field. The field notebook is in the middle of a $1.5 \mathrm{~m}$ thick gypsum unit at the Alcova Dam locality. (E) Details of "jumbled" siltstone without recognizable sedimentary features in outcrop. This may result from the dissolution of salt at the surface that may be preserved in the subsurface.

sandstone (Fig. 6B-E). In thin sections, a pattern of angular patches of silt or sand (Fig. 6A, arrows) forms convolute layering (Fig. 6D-E). They have no discernable primary sedimentary structures in outcrop but have rare, weakly defined peds and root molds. In thin sections, root features have clay skins (Fig. 6B-C). Blocky calcite cement is common.

Beds of siltstone and fine sandstone with sedimentary structures pinch out in 6 meters or less (Fig. 7A, no. 2). Beds are between $20 \mathrm{~cm}$ and $80 \mathrm{~cm}$ thick and are weakly cemented. They have lower contacts defined by either slight erosion or soft-sediment deformation (Fig. 7C, no C). Sedimentary structures include cross-stratification, mud drapes, mud cracks, flame structures, and load casts. Cross-stratification includes tabular cross beds with tangential foresets and more rarely trough cross-beds. Bed tops commonly have current ripple marks and well-developed mud cracks.

\section{Interpretation}

The fine sandstone and siltstone lenses lithofacies are interpreted to have been deposited either by unconfined overland water flow or as wind-blown silt trapped by efflorescent crusts. Although similar sediment splays occur from levee breaches or sand overtopping river banks and onto flood plains, a fluvial interpretation is not favored because no other fluvial deposits occur in the Goose Egg Formation. Both unconfined flow and the trapping of course, wind-blow silt by efflorescent crusts is consistent with deposition on saline mudflats and sand flats surrounding salt-pans and ephemeral lakes.

Beds with sharp or slightly erosional bases, planer tabular or trough cross-bedding, and current ripples are consistent with deposition by unconfined flow to form sheets of sediment (North and Davidson, 2012). Beds do not have gradational tops, suggesting they are not formed from turbidity currents. Beds tops commonly have mud cracks, indicating exposure. In the alluvial system, unconfined flows can occur distal of distributive fluvial channelization to form terminal splays onto alluvial plains (Fisher et al., 2007). On the alluvial plain, unconfined flows moving into the shallow depression of saline pans and ephemeral lakes on the alluvial plan contributes to wet and dry mudflats and sand sheets (Hardie, 1984; Lowenstein and Hardie, 1985). The soft-sediment 
deformation below the fine sandstone and siltstone lenses is suggestive that they were emplaced on over-saturated sediment, likely in wet mudflats surrounding lakes or into the shallow lake water.

Continuous massive siltstone beds with sharp upper and lower contacts could either be formed from efflorescent crusts or be evidence of soil formation. Beds have discontinuous patches of silt and sand (Fig. 6A, D-E) similar to the chaotic bedding described by Smoot and Castens-Seidell (1994) that they interpreted as the remains of efflorescent crusts where the saline portion of the crust have been dissolved or blown away. Efflorescent crusts commonly form adjacent to ephemeral saline lakes during desiccation. Evaporative wicking in the vadose zone and subsequent evaporation of liquids at the sediment-air interface results in thick crusts of salts. Pockets within the efflorescent crusts act as traps for wind-blown fine-grained sediment, leaving behind angular patches of mud and silt after the salt crust dissolves or is blow away in turn (Smoot and Castens-Seidell, 1994; Hardie et al., 2009). Efflorescent crusts can cover large areas, particularly in the winter, when the water table is closer to the surface, resulting in the deposition of sand or silt units on mudflats otherwise dominated by clay-sized grains (J. Smoot, personal communication 2017). These angular patches of silt and chaotic bedding are associated with root casts and are weakly developed, suggesting they may also result from pedogenesis.

Weakly defined peds, clay skins, and root features are indicative of pedogenesis. Pedogenic overprinting is usually minor, with original sedimentary textures visible and without horizons or pedogenic accumulations of gypsum or carbonate. The sedimentary features are consistent with mudflats and sandflats that may be weakly colonized by flora and fauna. Inceptisols may develop in the distal areas of lake depressions, where flooding may only reach on a decadal scale or longer.

\section{Conglomerate Lithofacies}

\section{Description}

Rare conglomerates of gypsum or gypsum or carbonate mudstone clasts occur as either (1) 1.5 $\mathrm{m}$ to $2 \mathrm{~m}$ thick single beds at the base of carbonate successions or (2) $2 \mathrm{~cm}$ to $4 \mathrm{~cm}$ thick beds within $10 \mathrm{~cm}$ to $20 \mathrm{~cm}$ thick units of laminated carbonate. At Bessemer Bend, a thick bed of mostly well-rounded pebble- to cobble-sized gypsum clasts underlays the laminated carbonate lithofacies. This bed has an erosional base with up to $50 \mathrm{~cm}$ of relief into a unit of the massive to blocky red mudstone lithofacies. The bed also has an erosional top with up to $10 \mathrm{~cm}$ of relief and the laminated carbonate onlapping this surface (Fig. 3A-B, 12C). In other locations at Bessemer Bend and Casper, thinner beds of conglomerate are present with well-rounded to sub-rounded 
pebble- to cobble-sided gypsum and carbonate clasts. Clasts are in thin beds separated by laminated carbonate (Fig. 12A) or are embedded in a red mudstone matrix (Fig. 12B). Some of the carbonate clasts have gypsum clasts within them, and gypsum clasts form armor around the surface of larger carbonate grains, having the appearance of nuts stuck to the surface of a chocolate banana. All clasts are well rounded, highly spherical to moderately spherical, and have no evidence of cross-bedding or imbrication.

\section{Interpretation}

The thick beds of gypsum conglomerate are interpreted as lithified accumulations of pebbles from unconfined or weakly confined flooding events passing over and eroding gypsum beds. Gypsum can be rounded during transportation and deposited after flow velocities ebb, resulting in an erosive surface overlain with thick units of gypsum.

\section{Laminated Carbonate Lithofacies}

\section{Description}

Bedsets of the laminated carbonate mudstone lithofacies are between $5 \mathrm{~cm}$ and $20 \mathrm{~cm}$ thick, forming units up to $2.5 \mathrm{~m}$ thick. This lithofacies typically overlies either the laminated siliciclastic mudstone lithofacies or the conglomerate facies. The lithofacies is defined by alternating light grey or light pink (N6 to N8 or 10R 7/2) and dark grey (N2 to N5) lamina (Fig. 8A-B, 9) between 0.5 and $1.5 \mathrm{~mm}$ thick. Laminated carbonate lithofacies units are commonly interbedded with thin laminated siliciclastic mudstone lithofacies. Bedsets are commonly separated by thin $(>$ $3 \mathrm{~cm}$ ) laminated siltstone beds of gypsum beds (e.g., Fig. 9B). Units are laterally continuous and tabular with either sharp conformable bases or with laminae that onlap onto erosional surfaces (e.g., Fig. 3A).

Laminae are composed of carbonate and some clastic grains. Semi-quantitative XRD conducted on two samples detected between $91 \%$ and $95 \%$ calcite and $5 \%$ and $9 \%$ quartz with unquantifiable traces of other minerals. Clastic grains form a sharp base with a diffuse transition into a usually thicker carbonate upper part (Fig. 8A). Carbonate is dull carbonate mudstone with no distinct carbonate grains or crystals. Lighter colored lamina is composed of carbonate mudstone

and medium to coarse silt-sized clastic grains of quartz and gypsum, less common feldspars, and rare micas (Fig. 8C, D). Darker lamina is composed of carbonate mudstone with rare detrital grains (Fig. 8B). Detrital grains make up less than $30 \%$ of the unit, are angular to sub-rounded, and range from highly spherical (0.9) to moderately elongate (0.5). Some lamina sets have a 

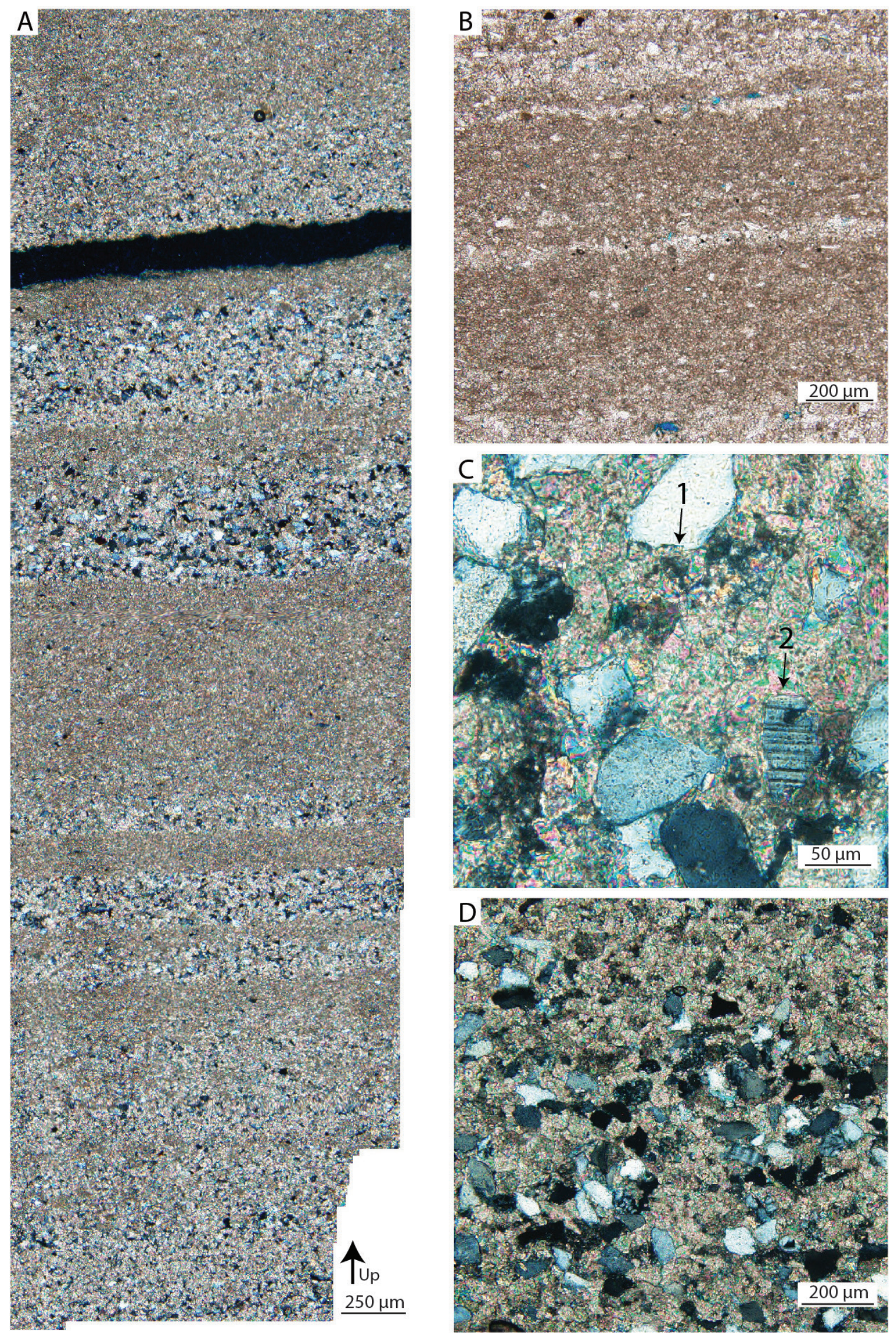
Fig. 8: Laminated carbonate photomicrographs. (A) The amount of clastics lamina in this cross-polarized light photomicrograph mosaic of a laminated carbonate lithofacies sample from Alcova Resivoure. Clastic-rich lamina have sharp bases and grade into the carbonate-rich lamina. (B) The laminated carbonate from the Bessemer Bend locality where thinner and lighter lammana is defined by increased clastic input, photomicrograph in plane-polarized light. (C) Detail of grains from a laminated carbonate in cross-polarized light. Grains show scalloped edges (no. 1) and gypsum grains with twinning (no. 2). (D) Quartz-rich lamana from wavy carbonate unit in cross-polarized light.

regular succession of the thin and thick laminae (Fig. 9C). Most laminae are parallel and laterally continuous.

Two rare and distinctive forms of laminations are present, crinkle lamina and small regular domes. Crinkle laminae form thin, crinkly partings (Fig. 9D). Crinkly laminations have an irregular angular surface with crinkles less than $0.5 \mathrm{~mm}$ in relief. These occur mostly as the top beds in units, particularly at Alcova Ranivore and Shell Creek. Crinkly laminations are commonly disrupted with isolated, oblong, white microcrystalline gypsum nodules up to $4 \mathrm{~cm}$ long and 2 cm high.

Other rare laminae compose small smooth laminated domes that are $8 \mathrm{~cm}$ to $12 \mathrm{~cm}$ across and are hosted by beds up to $30 \mathrm{~cm}$ thick. Laminae thicknesses are consistent through the domes, with each done separated by a narrow kink. Domes were observed in the float at Bessemer Bend, with domes in situ and oriented up at Alcova and in situ and oriented down at Shell.

\section{Interpretation}

Most of the laminated carbonate mudstone lithofacies are interpreted to have formed from the subaqueous suspension of sediment below wave base. Laminated carbonates are common in lacustrine settings (Eugster and Jones, 1979; Kelts and Talbot, 1990; Platt and Wright, 1991). Because the original grains are either too small or altered, it is possible that the original mineral was not calcium carbonate. For example, gypsum can readily alter to carbonate in the subsurface (Anadon et al. 1992). These laminations are interpreted to have formed in perennial lakes. Although laminated carbonates can form in marine settings, there are no marine fossils, trace fossils, or tidal bundles in the Goose Egg Formation's laminated carbonate mudstones to indicate a marine setting. There are no adjacent lithofacies indicative of transgressive or regressive facies. Stratigraphically, finely laminated rocks overlie conglomerates or paleosols here. Even when including other possible perennial lacustrine units, laminated carbonate mudstones only comprise thin units in otherwise thick successions of terrestrial and ephemeral saline lake deposits. 
This abrupt facies change suggests a low-relief landscape that can be quickly flooded and just as quickly return to an arid alluvial plain with ephemeral lakes.

In lakes, laminated carbonates or gypsum can form when the profundal zone receives variable sediment input (Gierlowski-Kordesch, 2010). Laminations can be attributed to: (1) variation in the grain size, mineralogy, or amount of clastic sediment that flows into the lake; (2) seasonal variations in carbonate-producing biota of the lake; (3) to variations in sediment distribution from turbidity currents, (4) regular alterations in the chemical environment resulting in variation in the precipitation of carbonate or gypsum. The laminations in the laminated carbonate lithofacies are defined by the number of detrital grains, suggesting variations in the clastic input control laminations. The presence of uniform, silt-sized clastic gypsum indicates the reworking of gypsum eroded from a local source. The variations of clastic inputs into perennial lakes are commonly seasonal, coinciding with increased water availability. However, non-seasonal rainstorms can drive clastic inputs, and dust storms could also cause regular variations in clastic input into lakes. Gradational transitions between clastic sediment and the thicker carbonate indicate that coarse grains could be turbidity flow events, perhaps triggered by flooding events or increased seasonal inflow that eventually wane and return to background sedimentation.

The preservation of laminations requires that the sediment is protected from disruption from bioturbation and physical reworking. Lamina preservation occurs in the profundal zone of lakes where anoxic or deep water creates stable conditions without benthic life, in saline lakes where high salinity precludes macroscopic burrowers, and in settings with rapid sedimentation (Gierlowski-Kordesch, 2010). The lack of any evidence of exposure suggests a perennial lake. Saline lakes can produce laminations at any depth or any lake size.

The small laminated domes are somewhat mysterious and non-diagnostic. Although stromatolites were considered for the small laminated domes, the consistent thickness of laminations in domes is not consistent with the thinning and pinching of lamina common in stromatolites. Also, the domes appear to be oriented down in at least one location, inconsistent with stromatolites. However, microbial mats can form undulating structures like those of the small domes. Alternatively, this could be soft-sediment deformation.

The crinkly laminations are similarly problematic. This crinkle lamination pattern resembles the irregular surface lamination pattern created by dendritic carbonate growth in spring deposits (Jones and Renaut, 2010). Microbial influence is common in springs, mudflats, and throughout the photic zone in a wide range of salinities from brackish to brine (Riding, 2000; Jones and Re- 
naut, 2010). The crinkle lamina and the small laminated domes both likely formed from springs, either subaqueous or subaerial, with significant microbial influence.

Gypsum nodules are present in the laminated carbonate facies, and this feature can form in tidal flat environments or saline lakes, or saline mudflats. The nodules in the Goose Egg Formation lacks the typical chicken-wire texture of tidal flat gypsum. In saline lakes, gypsum nodules form from groundwater adjacent to saline lakes, exposed wet mudflats, and lacustrine carbonates undergoing pedogenesis (Hussain and Warren, 1989; Rosen, 1991; Goldberg et al., 2011).
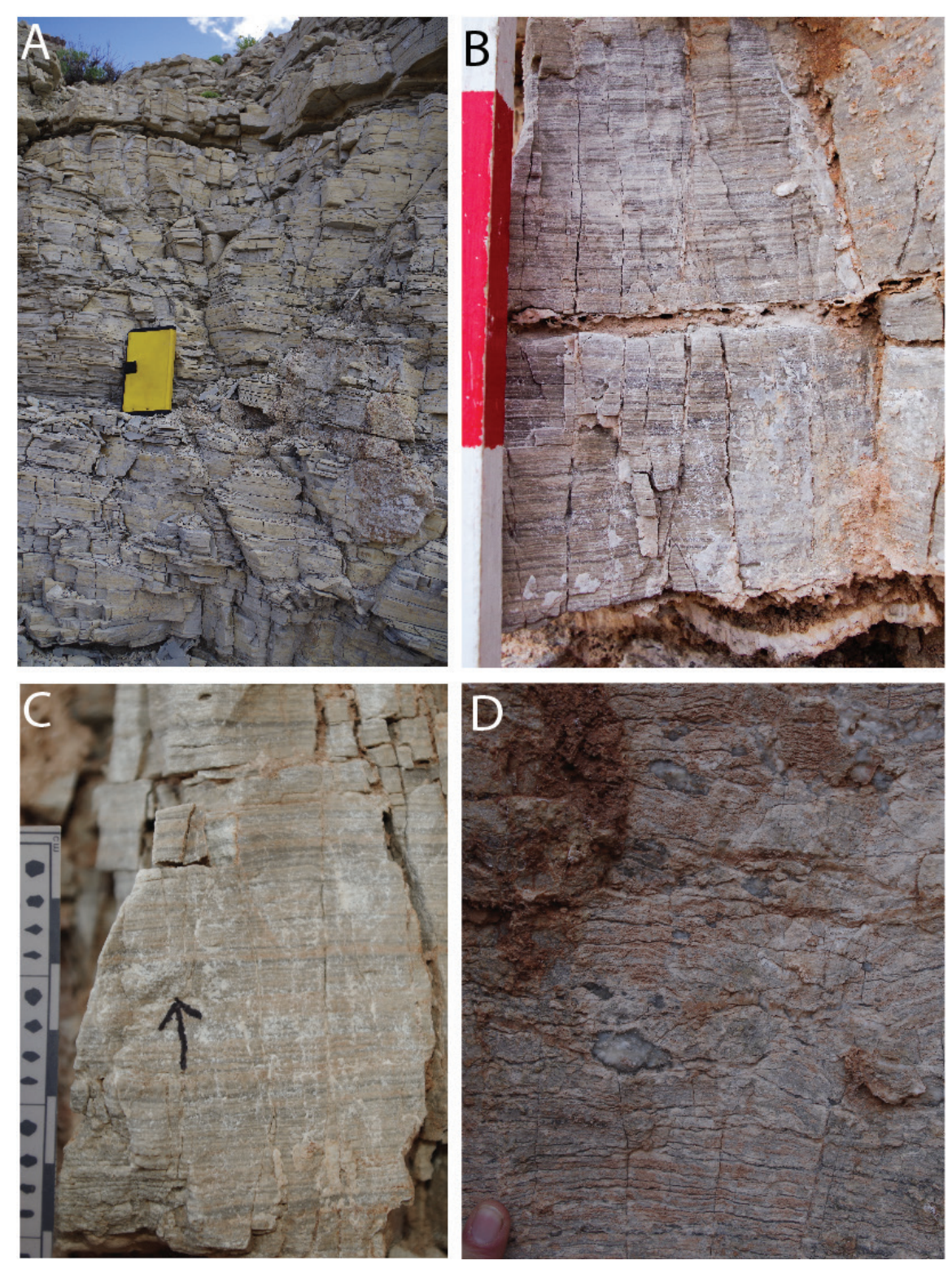

Fig. 9: Outcrop Details of Laminated Caroantes. (A) Laminated carbonates at the Alcova Dam locality. (B) Details of alternating dark and light laminations at the Bessemer Bend Locality. The red band on the scale bar is $10 \mathrm{~cm}$. (C) Alternating light and dark lammana with regular pinkish thick lammana. Scale bar alternations are $1 \mathrm{~cm}(D)$ Laminated carbonate with "crinkle" lammana and gypsum nodules. 


\section{Bedded Carbonate Lithofacies}

\section{Description}

The bedded carbonate lithofacies form units up to $2 \mathrm{~m}$ thick (Fig. 10), typically stratigraphically above laminated carbonate mudstone lithofacies (Fig. 3). Carbonate beds are $3 \mathrm{~cm}$ to $10 \mathrm{~cm}$ thick $\tan (5 \mathrm{Y} 9 / 3$ to $5 \mathrm{Y} 7 / 2)$ to light grey (N6 to N8) mudstones. No fossils or carbonate grains can be seen in the outcrop. Therefore, the bedded carbonate lithofacies is a mudstone after Dunham (1962). Beds commonly pinch and swell or pinch out and have weakly defined laminations (Fig. 10B). Most beds have low-angle, tangential wedge cross-bedding. Other sedimentary features include vertical cracks, mud cracks (Fig. 10C, F), and root traces (Fig. 11D, no. 1-3).

Carbonate grains are indistinct, closely packed peloids or roughly rounded grains of homogeneous carbonate. Peloidal grains have diffuse grain boundaries, often with a darker rim. Rarely, interlocking crystal mosaic can be seen. Peloids merge into dull carbonate mud or an indistinct interlocking crystal mosaic. Most peloids are surrounded by a dark grey or light red rim. Rare microfossils (Fig. 11B, point 1) are present. These fossils are 0.4 to $0.8 \mathrm{~mm}$ long asymmetric shells between $0.1 \mathrm{~mm}$ and $0.2 \mathrm{~mm}$ in height. The identification of these rare microfossils was not possible. Up to $20 \%$ of the lithofacies are clastic grains of gypsum, quartz, rare feldspar, and micas. Detrital grains are silt-sized sub-rounded to sub-angular grains with moderate sphericity (0.7). Some detrital gypsum grains are large (medium sand) and angular (Fig. 11C, no. 3). Semi-quantitative XRD conducted on one sample resulted in approximately $85 \%$ calcite, $13 \%$ quartz, and less than 5\% dolomite. Iron staining is common in detrital grains (Fig. 11C, no.1).

The tops of units often have a laterally extensive, massive, vuggy carbonate bed up to $35 \mathrm{~cm}$ thick (Fig. 10D, no. 2,4). Empty vugs or vugs filled with a druzy calcite cement are between 1 and $5 \mathrm{~cm}$ across and are typically aligned in horizontal layers. These massive beds are very fine-grained carbonate and contain root traces and suspect burrows (Fig. 11 A, E). Poorly sorted siliciclastic grins define the unit in thin sections (Fig. 11A, no.2). A red, irregular, terra rosa surface (Fig. 10D, no.2) was observed near the tops of units at Bessemer Bend and Shell Creek. This terra rosa was associated with well-developed mud cracks (Fig. 10F) and large vugs. In one locality, the unit's tops have unusual concave up bedding to form domes up to $7 \mathrm{~m}$ across (Fig. $10 \mathrm{E}$, arrows). The domes are comprised of upward doming laminated bedsets 2 to $6 \mathrm{~cm}$ thick with the sub-millimeter lamina. Bedsets form rough concentric circles that arc upward (Fig. 10E, dashed lines) and are collapsed in the center, filled with gypsum, or more rarely, domes are not present, and an appropriately sized circular depression is present. The dome covers the entire exposed bedding surface, an area $200 \mathrm{~m}$ by $90 \mathrm{~m}$ with domes spaced between 10 and $15 \mathrm{~m}$ apart, and the bedding surface between the domes covered in wave ripple marks and mud cracks. 


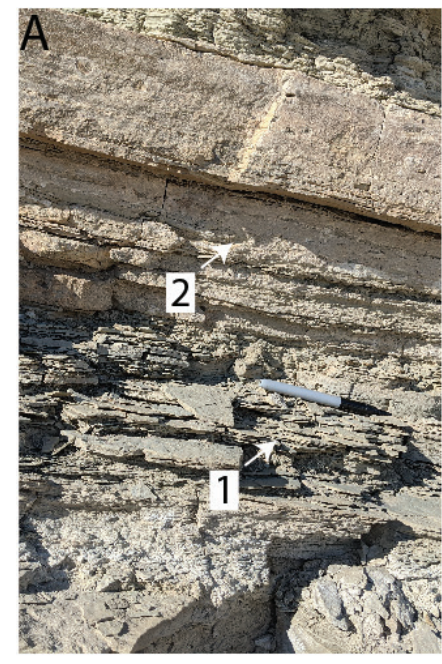

D

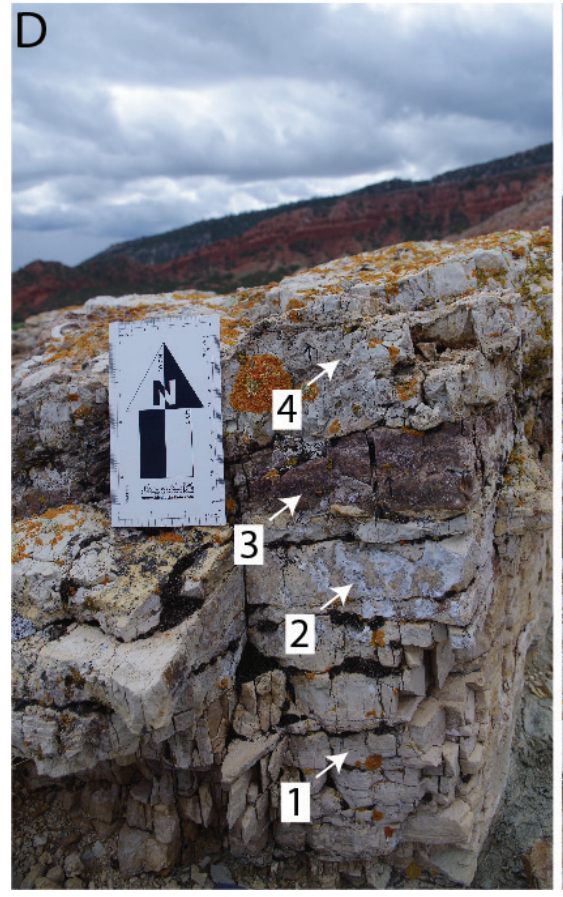

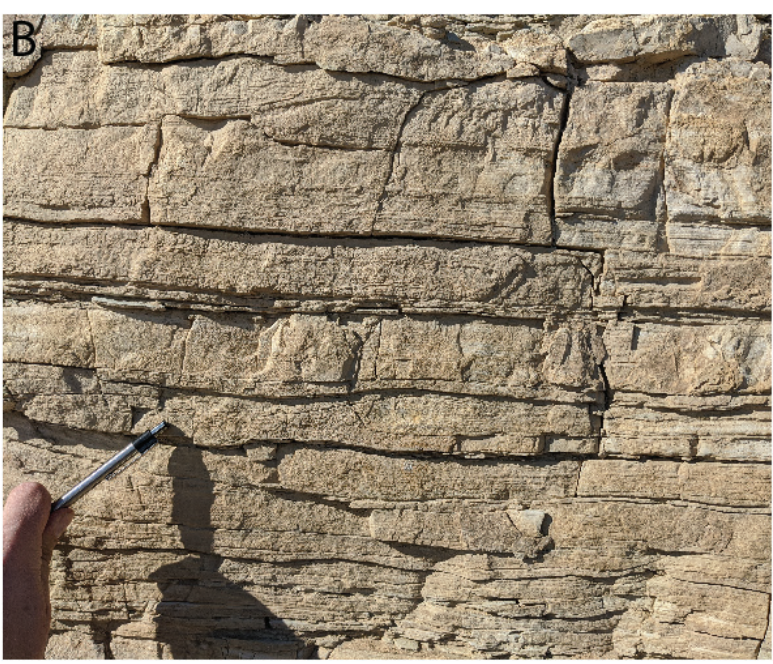

$\mathrm{E}$
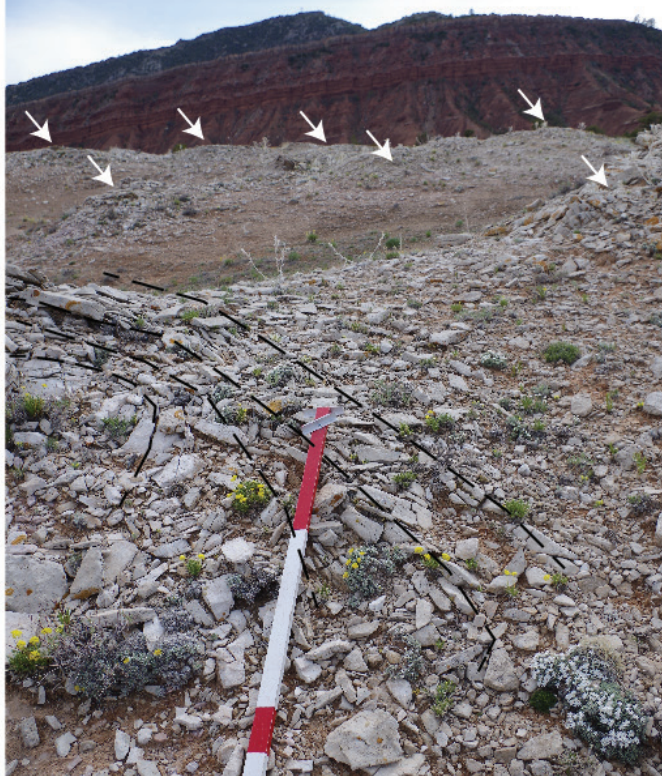

Fig. 10: Bedded carbonate in outcrop. (A) Bedded carbonate at Shell Canyon showing interbedded drab siliciclastics (no. 1) and carbonate beds (no. 2). (B) Bedded limestone at the Alcova Dam locality with pinch and swell beds and some low-angle wedge cross-bedding with nearly parallel tangential foresets. (C) Bedding plane view of mud cracks on the top of the unit showing in B. (D) Bedded carbonate unit at Bessemer Bend with bedded low-angle wedge cross-bedding (no. 1), massive vuggy carbonate beds (no. 2, 4), and a terra rosa bed (no. 3). (E) Bedding forms ambiguous domes structures (arrows) on the top of a carbonate bed at the Bessemer Bend locality. The concentric circles of upward doming beds (dashed lines) can be seen in the foreground. (F) Bedding plane mud cracks at the Bessemer Bend locality near large domes. The red and white scale is $1.5 \mathrm{~m}$ long with small alternations $10 \mathrm{~cm}$ and the large alternation $0.5 \mathrm{~m}$. 

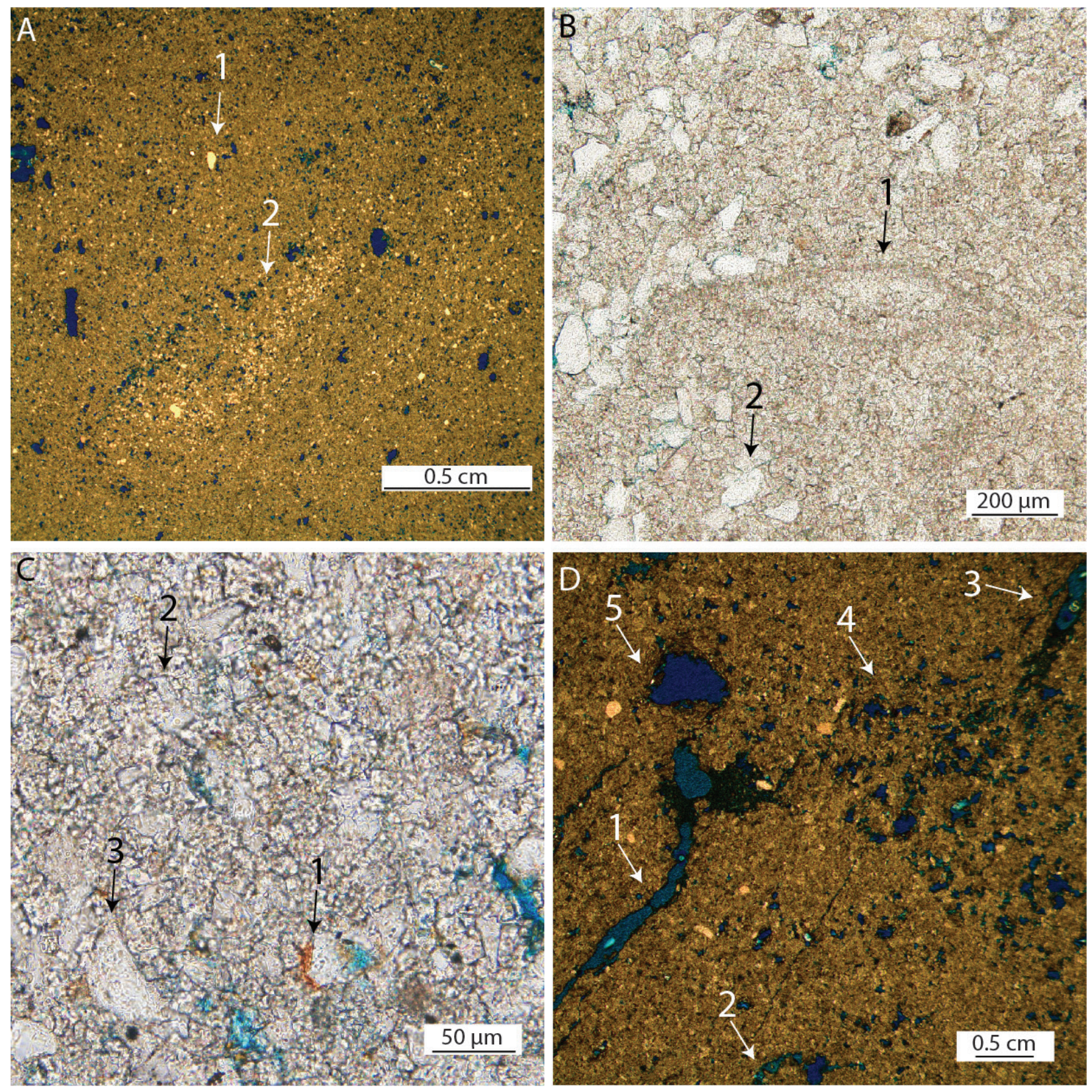

Fig. 11: Photomicrographs of the bedded carbonate lithofacies. (A) Massive vuggy carbonate from the Alcova Dam locality with large clastic grains (no. 1) and disrupted beds of silt (no. 2), photomicrograph in transmitted and reflected light. (B) Fossil from the bedded carbonate (no. 1) and sub-rounded silt-sized quartz grains (no. 2) with linear grain boundaries indicating some compaction in plane-polarized light. (C) Detail photomicrograph of clastic grains with iron staining (no. 1), carbonate grains that have undergone some neomorphism (no. 2), and large angular clastic grains (no. 3). (D) Photomicrograph of massive carbonate in both transmitted and reflected light. Root features are defined by tapering ends and branching (no. 1, 3). Clay skins (no. 2, 5) form around voids that could be burrow fills or transverse root features cuts. Porosity is suggestive of biological activity (no. 4). 


\section{Interpretation}

Bedded carbonate is interpreted to have been deposited above wave base in an ephemeral lake. Carbonate and associated siliciclastic grains are likely detrital or locally reworked. Parallel pinch and swell bedding and parallel lamina result from deposition in low-energy subaqueous environments. The weakly visible peloidal texture could have been pellets, micritized skeletal or coated grains, or reworked carbonate mud fragments. It is also possible that the original grains were not originally carbonate, but replacement of carbonate after gypsum. Peloids are non-diagnostic but highly suggestive of an original carbonate mineral. The low-angle wedge cross-bedding with sub-parallel tangential foresets results from this sediment's reworking with the migration of mostly straight crested or two-dimensional mega ripples or dunes. Reworking could have occurred from subaqueous currents, waves, unconfined overland flow, or wind.

Mud cracks, root traces, and terra rosa are indicative of exposure. Cracking is on most bedding surfaces, indicating frequent exposure. It is likely that these beds formed mudflats over a large area and were only occasionally inundated. The formation of terra ros $a$ and the presence of root traces and soil features suggest longer periods of exposure where plants can colonize surfaces and incipient soils form. Terra rosa has been attributed to dissolved carbonate's insoluble residue (Isphording et al., 1995). However, Wright (1994) noted that the amount of carbonate to be dissolved to result in even a thin insoluble layer is unrealistic. Instead, terra rosa in carbonates develops in the presence of significant atmospheric dust input.

Massive and vuggy beds near the tops of units are interrupted to be paleosol horizons. Massive pedogenic carbonate horizons form from mottles' coalescence or horizons' bioturbation (Achauer, 1987; Platt, 1989; Wright, 1994). Massive pedogenic carbonate horizons are often impediments to infiltration, causing localized ponding to trap dust or precipitate authigenic minerals. That terra rosa only occurred above massive carbonate beds supports a pedogenic origin for the massive units.

The large domes on the top of a bedded carbonate lithofacies in Bessemer Bend are an enigma. They could be the 3D expression of teepees, large microbial mounds, or spring deposits. Their occurrence as large, evenly spaced mounds or depressions and morphology of concentric rings most closely resemble spring deposits (Jones and Renaut, 2010). The crinkle laminations and small lamented domes of the laminated carbonate facies support that springs were prevalent. 

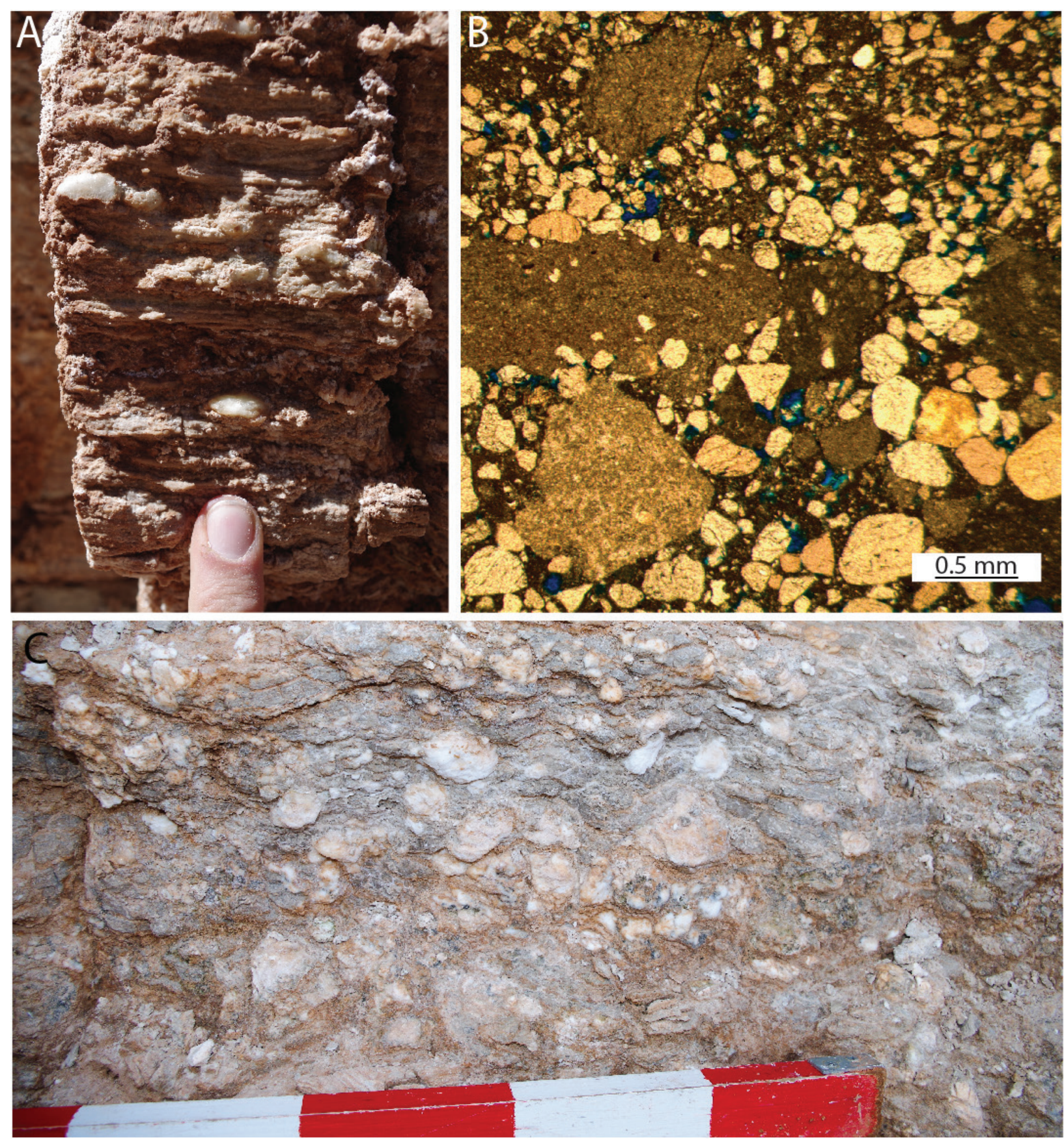

Fig. 12: Rubble bed from the Bessemer Bend locality in outcrop (A) and thin section (B) showing carbonate clasts that are "coated" in well-rounded gypsum particles. (C) The thick conglomerate bed below laminated carbonate. 


\section{Description}

The bedded gypsum lithofacies is comprised of thick units of gypsum (Fig. 13-14) that can be traced laterally in outcrop for up to $1.6 \mathrm{~km}$ on foot at the Alcova Dam locality, $1.4 \mathrm{~km}$ by drone at Casper Mountain, $0.8 \mathrm{~km}$ on foot at Bessemer Bend, and approximately $2 \mathrm{~km}$ by drone at Shell. Beds may extend farther, but they could not be physically traced from outcrop to outcrop. In a $9 \mathrm{~km}$ long outcrop at Alcova Dam, the outcrop's western end has four units of bedded gypsum lithofacies, and the eastern end has two.
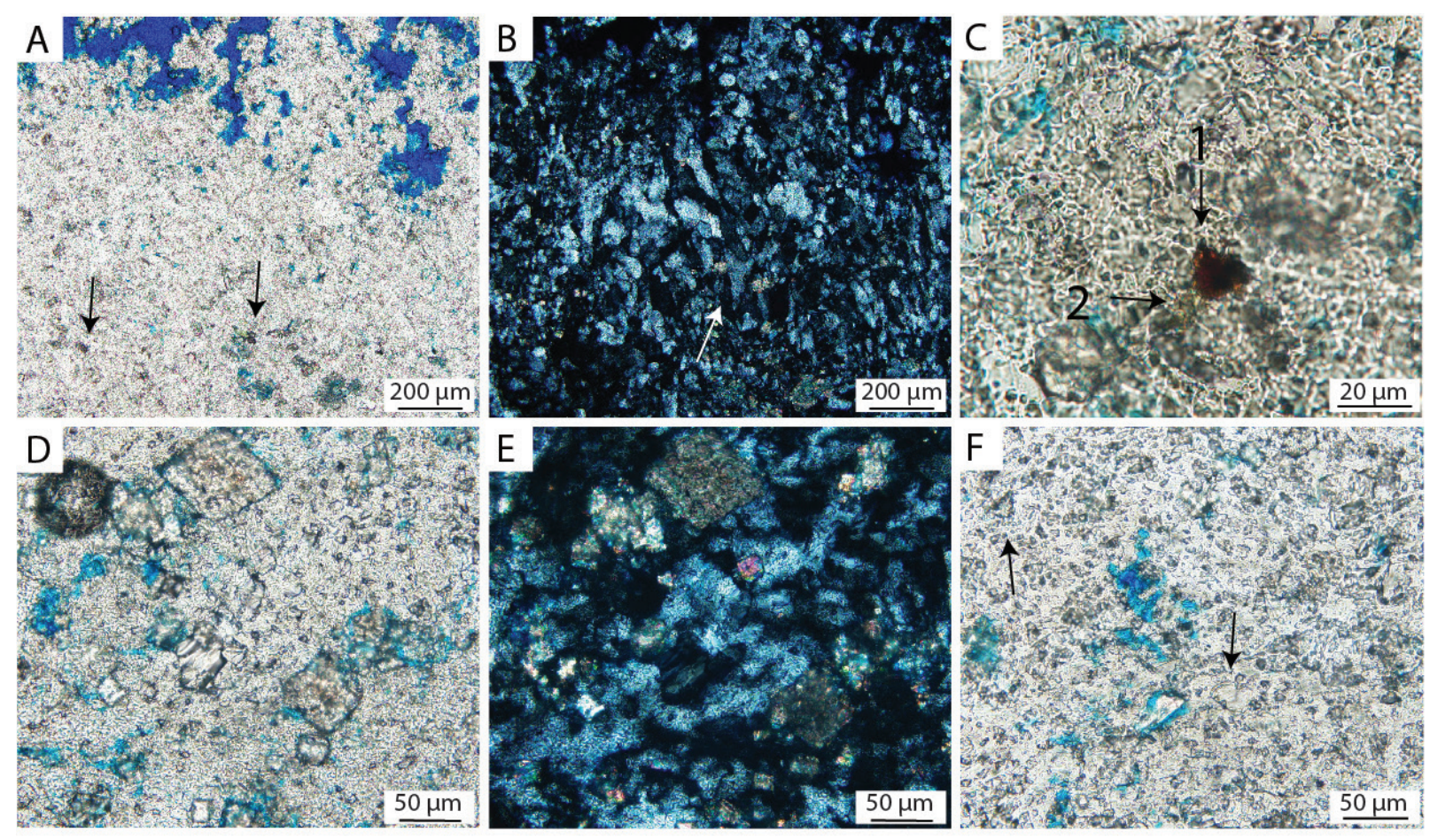

Fig. 13: Gypsum photomicrographs. Gypsum that has been weathering at the surface makes imperfect photomicrographs. (A) A combination of surface dissolution and many conversion cycles between gypsum and anhydrate has obscured deposition texture in favor of massive gypsum with traces of siliciclastics (arrows). However, in cross-polarized light (B), hints of an original bottom growth layer can be seen, including what looks to be a swallowtail crystal (arrow). (C) In addition to siliciclastic grains, iron oxides (no. 1) are present and stain the surrounding gypsum (no. 2). (D) Secondary dolomite crystals in plane-polarized light and cross-polarized light (E) could be the first stages of more comprehensive gypsum recrystallization. (F) Details of siliciclastic grains suspended in a gypsum matrix. 

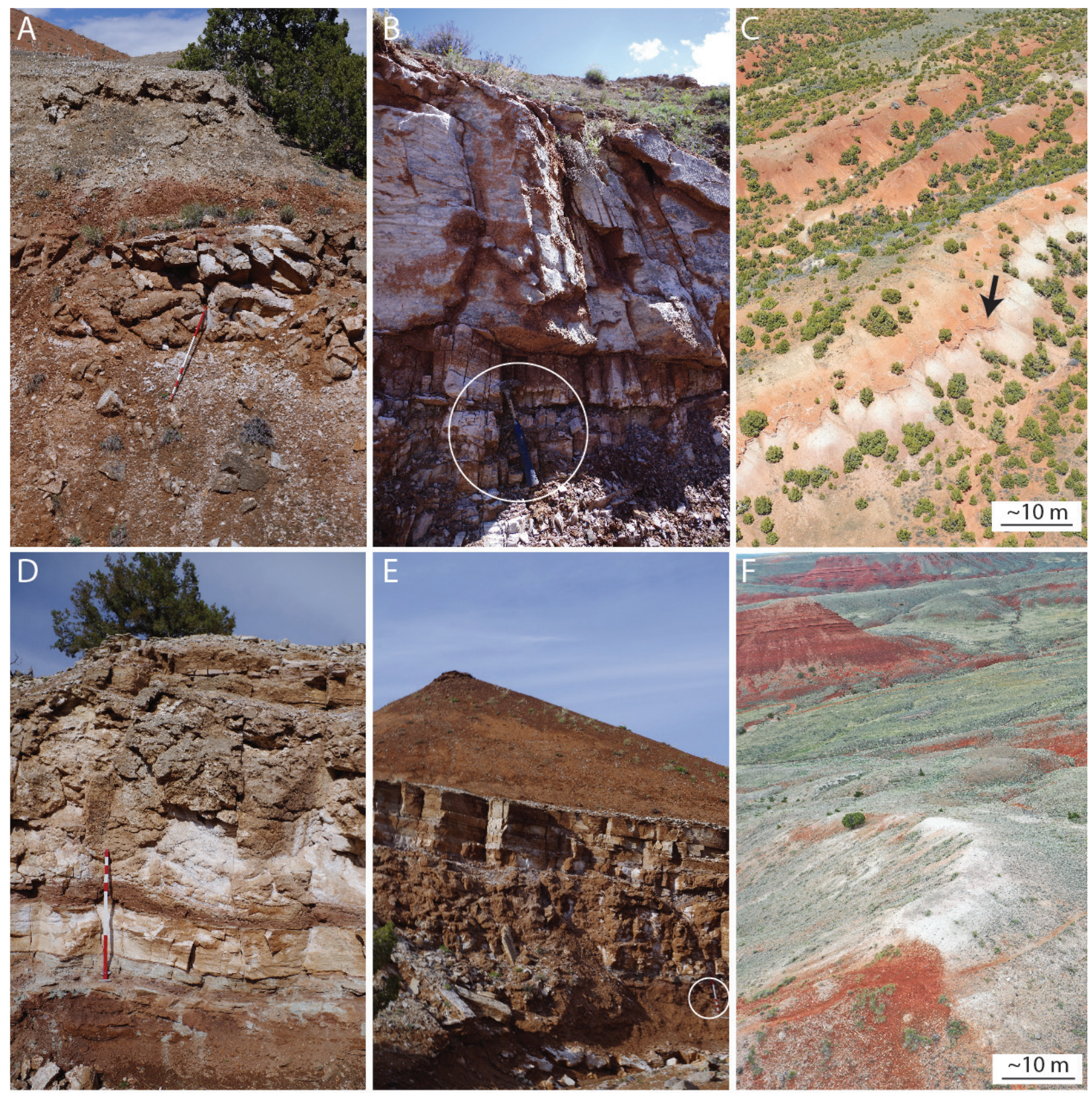

Fig. 14: Gypsum in outcrop. (A) Highly weathered gypsum in outcrop at Bessemer Beds. (B) Gypsum bed in hillslope at Casper Mountain locality. (C) Aerial photograph of gypsum beds at Casper Mountain locality. (D) Teepee structure in gypsum at the Bessemer Bend locality. (E) Thick gypsum bed with sharp contact with red sandy siltstone at Bessemer Bend locality. (F) Ariel photograph of gypsum beds at the crest of a grassy hillslope at the Shell Canyon locality. 
Bedded gypsum lithofacies units can be up to $5 \mathrm{~m}$ thick and comprised of multiple bedsets. Bedsets range from 20 to $150 \mathrm{~cm}$ and comprise thin beds between $2 \mathrm{~cm}$ and $4 \mathrm{~cm}$ thick of gypsum separated by red mud partings (Fig. 15B). The red mud often has "kinks" or follows an irregular or jagged pattern. Most beds are laterally extensive (Fig. 15C), but discontinuous mud drapes exist (Fig. 15D). At Bessemer Bend, a gypsum teepee structure over $1.5 \mathrm{~m}$ tall was observed (Fig. 14D).

Most of the gypsum is highly weathered, obscuring any features (Fig. 15A, F). The bedded gypsum units contain vertical textures when viewed in thin section under cross-polarized light. Some in situ swallowtail gypsum crystal shapes are as large as $2 \mathrm{~cm}$ tall and competitive crystal growth fabrics (Fig. 13). Associated with these bottom-growth gypsum crystals are quartz, iron oxide, and mica sand, and silt. Secondary dolomite crystals and unidentified crystals with high birefringence are also common.

\section{Interpretation}

The bedded gypsum lithofacies is interpreted to be composed of beds of bottom-growth gypsum. The vertical orientation of crystals, the presence of swallow-tail gypsum crystal shapes, and the competitive crystal growth textures are characteristic of bottom-growth gypsum. In modern environments, bottom-growth gypsum is only known to form as a chemical precipitate from saline surface waters (Eugster and Hardie, 1978). Gypsum is a common precipitate in saline lakes (Hardie, 1984; Lowenstein and Hardie, 1985; Smoot and Lowenstein, 1991) and evapoconcentrated seawater in lagoons. The mud drapes are either composed of clastic mud particles settling from suspension or clay minerals directly precipitated from the saline surface water. The jagged surface of the mud partings preserves some of the bottom growth crystal shape. Large teepee structures likely formed during desiccation stages when bedded gypsum was exposed and distorted at the surface. These characteristics strongly suggest that the bedded gypsum lithofacies formed an ephemeral saline lake enriched in $\mathrm{Ca}^{2+}$ and $\mathrm{SO}_{4}^{2-}$. 

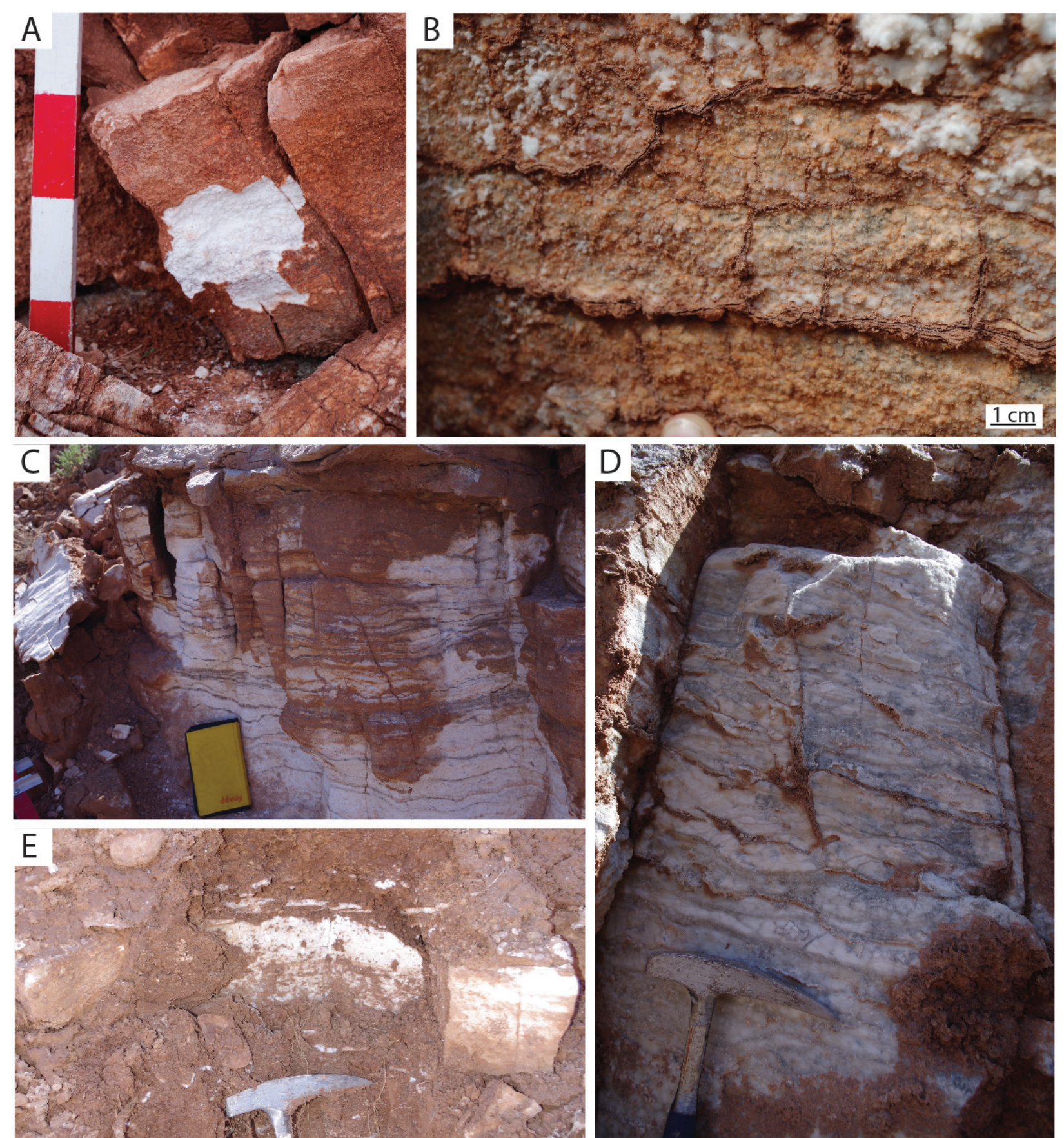

Fig. 15: Details of gypsum. (A) Bright white gypsum exposed in a gypsum bed at Alcova Dam locality. The red mud from surrounding units coats the gypsum, making it hard to recognize in the field. (B) Detail of gypsum bed at the Bessemer Bend locality showing uneven or "jagged" mud draped over 2 to $3 \mathrm{~cm}$ thick gypsum beds. (C) Jagged gypsum mud drapes in Shell Canyon locality gypsum. (D) Discontinuous mud drapes in gypsum at Bessemer Bend Gypsum. (E) Thin gypsum beds in Alcova Dam red beds, many such gypsum beds are likely missed on weathered hillslopes. 


\section{DISCUSSION}

\section{The Environment of Deposition of the Goose Egg Formation}

No evidence was found for a marine origin in any of the Goose Egg Formation beds within this study area. The red beds, carbonates, and gypsum of the Goose Egg Formation were deposited in continental environments on an alluvial plain (Fig. 16), with specific depositional environments including distal alluvial fans, perennial saline lakes, ephemeral saline lakes, and saline mudflats. The assemblage of sedimentary features supports depositional interpretations. Frequent flooding, evapoconcentration, and desiccation were important processes in the Goose Egg Formation's depositional environments.

The presence of carbonates and gypsum has been used as evidence of a marine origin for the Goose Egg Formation, and it is indisputable that there are thin carbonates and gypsum units. However, carbonates and gypsum are common saline lake constituents (Smoot and Lowenstein, 1991; Hardie et al., 2009; Matter and Tucker, 2009). The Goose Egg Formation is not associated with any unambiguously marine or marginal marine sedimentological features. Few of the carbonates had identifiable original carbonate grains and could have been originally deposited as gypsum or other minerals. Hardie (1984, p. 204) gives the following criteria for distinguishing marine and non-marine evaporites and associated rocks: (1) sedimentological criteria such as the fossils present, the nature of associated facies, and stratigraphic position; (2) mineralogical criteria such as the kinds of primary minerals present and the vertical association of those minerals; (3) chemical criteria such as the trace elements and fluid inclusion geochemistry. Each of these criteria will be examed in turn.

Within the Goose Egg Formation, no unambiguously marine body fossils, sedimentary structures, or trace fossils were observed. There are no tidal bundles observed in any units, nor tidal channels or other tidal features. The single occurrence of gypsum nodules is isolated and lacks the distinctive "chicken wire" texture of tidal flat gypsum. The presence of roots, abundant exposure surfaces, and efflorescent crusts' deposits support a continental deposition environment. Continental environments of deposition can adequately explain all features of the Goose Egg Formation. The presence of peloids is not-diagnostic, much of the original sediment texture has been obscured by recrystallization and neomorphism, and many of the carbonates could have been originally deposited as gypsum. The carbonates of the Goose Egg Formation have few fossils or bioturbation and abundant evidence of exposure, indicating frequent desiccation of a saline lake. 
Fig. 16: Diagrammatic facies models. The Goose Egg Formation is a mosaic of environments including wind-dominated planes (A), dry lake beds (B), and shallow saline lakes $(C)$ in underfilled lake basins, and larger perennial saline lakes (D) in balanced-filled lake basins. Those environments can be considered within the Carroll and Bohacs (E), where the evolution of basin type can be accounted for by either increasing aridity or changes in hydrological input.
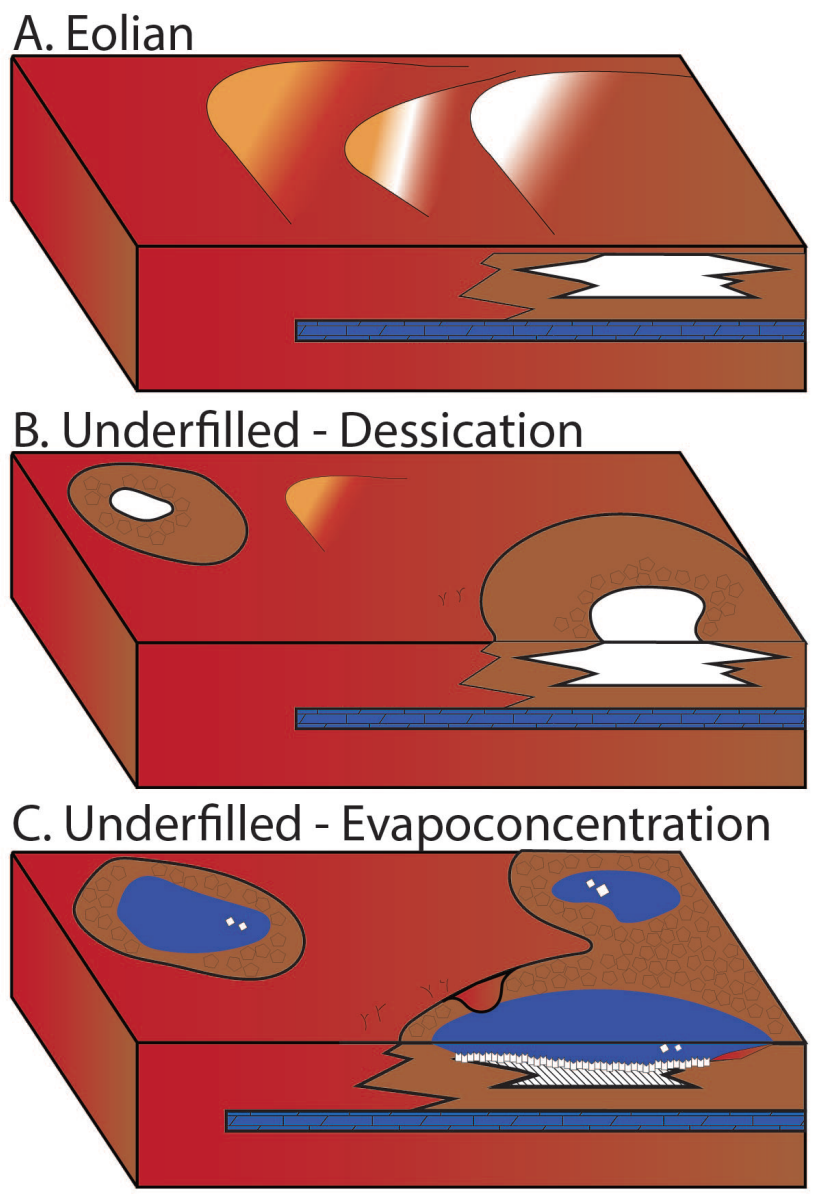

D. Balanced Filled - Saline Lake

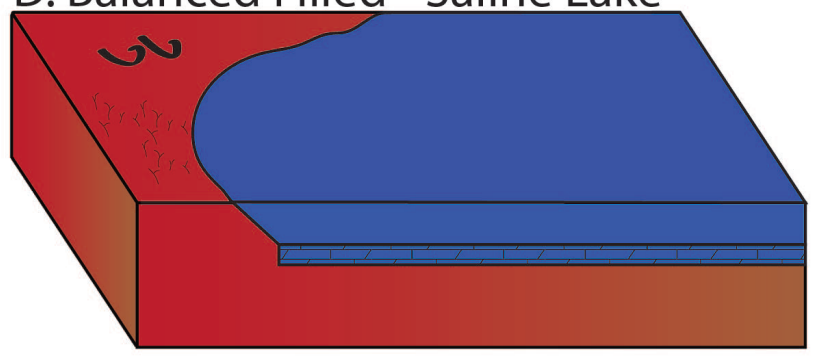

E. Lake-type Model

Modified from Carroll and Bohacs (1999)

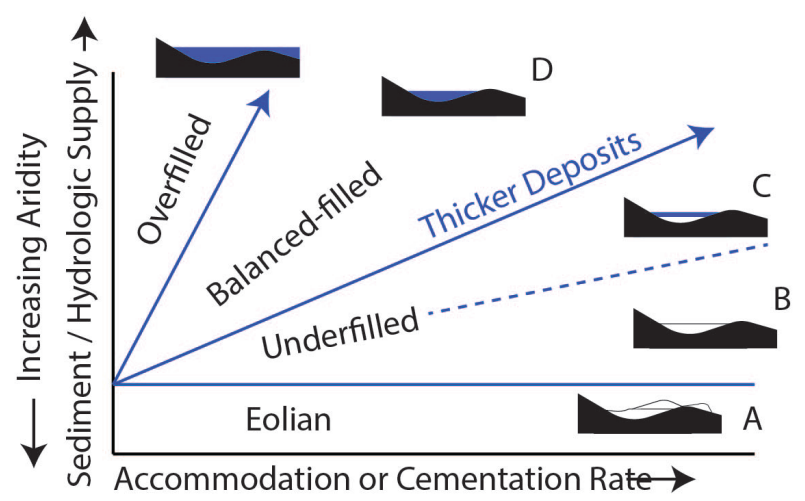


Stratigraphic considerations are important to consider when evaluating. The Pennsylvanian and early Permian rocks below the Goose Egg Formation are unambiguously continental eolian dunes and soils (Opdyke and Runcorn, 1960; Schenk et al., 1986, 1993; Pollastro et al., 1991; Cole et al., 1992). The overlying Red Peak Formation of the Chugwater Group predominantly comprises red beds deposited through alluvial and fluvial processes and altered by pedogenesis (Chapter 2 of this dissertation). Though carbonates and gypsum are laterally extensive, they are not correlative across the Goose Egg Formation's entire occurrence. Their area and stratigraphic extent are consistent with other saline lake deposits (Eugster and Hardie, 1978; Bell, 1989; Gierlowski-Kordesch, 2010). No evidence of lateral thicking of carbonate or gypsum facies was found. Gypsum and carbonate were laterally extensive, but units did pinch out eventually. There is no lateral transition to marine facies. It is 300 kilometers from the easternmost outcrop of the Phosphoria Formation to the last known outcrop of the Goose Egg. Marine transgressions capable of progressing 300 kilometers into the continent's interior would leave behind features like a transgressive lag, adjacent deepening or shallowing facies, regionally traceable sequence boundaries, or flooding surfaces. None of this is present; there are no transgressive or regressive facies stacking patterns typical of deposits driven by eustasy (Posamentier, 2009).

Other workers have also used correlation to the Phosphoria Formation as evidence of the Goose Egg Formation's marine origin. The Phosphoria is a unique marine environment characterized by carbonate and bioelemetal accumulations of phosphorites and cherts (Matheson and Frank, 2020). Correlations between the Phosphoria and the Goose Egg are questionable (see below). This study supports the conclusions of Paull and Paull (1990), that " [ $\mathrm{t}$ ]here is no positive documentation to support a marine origin for the [upper Goose Egg Formation]. However, the persistent nature of this member and the presence of gypsum and dolomitic limestone might indicate deposition in a marginal marine environment. Similar sediments could accumulate in an inland evaporitic sea between the craton and the exposed Permian surface to the west." Resolving the apparent contradiction between the red beds of the Goose Egg Formation and their correlative association with the Phosphoria Formation (Fig. 18) has occupied most of the study of the previous Goose Egg. Thomas (1934) resolved the apparent contradiction of gypsum and limestones of "undoubted marine origin" in close association with red beds by assigning the red beds to a marine origin. Thomas used the lack of mud cracks or raindrop imprints and the lateral continuity of the red beds as evidence of a marine origin, particularly compared to the unquestionably terrestrial Fountain Formation of Colorado (USA). Thomas suggested that upland red soils transported into a "specialized marine environment" that prevented the reduction of the ferric iron. However, this perception of continental sediments was made before a detailed sedimentological study of continental environments was undertaken In the latter half of the $20^{\text {th }}$ century. 
Mineralogical criteria are somewhat more ambiguous, particularly as all potential halite or other saline minerals have been dissolved from the Goose Egg Formation at the surface. However, the assemblages of minerals present and their proportions provide some inference to the parent waters' chemistry. Gypsum and carbonate alone are not sufficient to differentiate coastal from inland saline lakes. Coastal saline lakes, ephemeral lakes, and pans tend to accumulate more gypsum and carbonate, particularly high-magnesium carbonate and dolomite (Schreiber, 1988). The precipitation of carbonate and gypsum from continental sourced brines in closed basins has been well documented (Eugster, 1980; Hardie, 1984; Lowenstein and Hardie, 1985; Hammer and Dumont, 1986; Bell, 1989; Kelts and Talbot, 1990; Hardie et al., 2009). Most of the most helpful minerals in differentiating between brines with parent fluids derived from marine fluids and non-marine fluids are the late-stage saline minerals that may have been completely dissolved from the Goose Egg Formation (Hardie, 1984). Although inconclusive, some mineralogical evidence is suggestive in a continental environment. First, most deposition, particularly in the upper Goose Egg Formation, seems to be gypsum/anhydrite and halite only with disrupted beds preceding thin gypsum beds. The carbonate and gypsum precipitated are minor compared to the red beds and saline minerals. The mineralogical criteria suggest a non-marine parent brine but are not diagnostic.

Chemical criteria, particularly from fluid inclusions, are not possible from the Goose Egg Formation's outcrops. Ancient bedded halite can preserve primary fluid inclusions, which are remnants of the parent surface water; these preserved fluid inclusions can be analyzed for past surface water temperatures, salinity, major ions, $\mathrm{pH}$, pressure, and microorganisms (Goldstein, 2001). Halite intergranular cement and displacive crystals can provide similar data for past parent groundwaters. However, for primary fluid inclusions to be studied, the host halite must have been protected from alteration from burial and dissolution from both natural dilute waters and drilling fluids (Benison et al., 2015). In the lithologically-equivalent formations from elsewhere in the midcontinent, cores drilled with salt-saturated brine mud or hydrocarbon drilling muds (invert) attest to depositional and early diagenetic halite, even though no halite is preserved in outcrop (Benison et al., 2015). Although well logs suggest halite in the Goose Egg Formation, no cores have been drilled with appropriate methods to retrieve any subsurface halite. However, halite likely existed in the depositional environments of the Goose Egg Formation. The interpretations of the Goose Egg's environmental conditions include saline lake waters, a paucity of vegetation, wind, and aridity, all characteristics of lakes that precipitate halite. Though the halite is not present at the surface, halite casts are evidence that it was present in the past. The similarity between the Goose Egg and other Permian-Triassic red beds and evaporites, especially the Nippewalla 
Group and Opeche Shale, which both have no halite in outcrops, but have halite in the subsurface, supports this possibility that the Goose Egg Formation hosted depositional and early diagenetic halite. Late-stage dissolution of halite may have led to the friable and massive nature of some of the siliciclastics.

A continental deposition environment dominated by saline lakes could result in a thick succession of saline minerals (Hardie, 1984). Rasmussen and Bean (1983) use sonic logs to map subsurface salt in the Powder River basin between the Black Hills Uplift and the Bighorn Mountains. Thick beds of halite, separated by anhydrite, account for up to $70 \%$ of the upper Goose Egg Formation, occurring in pods that correspond with basement lineation. Rasmussen and Bean attribute the discontinuous nature of salt from salt dissolution and collapse during the Mesozoic. An alternative explanation is that basement involved faulting contributed to both the spatial occurrences of saline lakes by providing local shallow depressions during Goose Egg time and impacting sedimentation into the Mesozoic. The discontinuous nature of saline mineral accumulation is consistent with deposition in continental environments and explains the massive siltstone at the surface.

It is possible that much of the red mud and siltstone were interbedded with now-dissolved saline minerals like halite. Near-surface, late-stage dissolution of bedded halite, displacive halite, and halite cement could have resulted in the massive red beds and gypsum observed in the Goose Egg Formation, similar to these processes documented in the Permian Nippewalla Group red beds and gypsums in western Kansas (Benison et al., 2015). Like the Nippewalla Group, the Goose Egg has halite casts and poorly cemented massive red sediment. Additionally, thick halite beds have been reported in the Goose Egg Formation in the subsurface (Rasmussen and Bean, 1983). Halite cases further support that halite was present but has been dissolved close to the surface.

Soils can be preserved in the rock record. Some paleosols preserve laterally continuous interfluvial horizons (Retallack, 1998). Both tropical and dryland soils can form red beds (Walker, 1967b, 1967a, 1974). Loess deposits are also laterally continuous horizontal terrestrial deposits intimately related to soil development that have been recognized as forming ancient red beds with continuous beds (Smalley, 1966; Tsoar and Pye, 1987; Wright, 2001; Soreghan et al., 2008a). The channelization and abrupt lateral facies changes from the Fountain Formation, a fluvial and proximal alluvial fan system, is atypical of red bed deposition. Overprinting of soil features occurs across most lithofacies, further reinforcing a continental environment of deposition. Soils only form in sediments exposed at the earth's surface and subject to biological activity 
and weathering. Root traces, burrows, and bioturbation indicate surfaces were not only exposed but were colonized by life. Terra rosa exposure surfaces, soil peds, and massive carbonate soil horizons only form prolonged exposure at the surface (Platt, 1989; Krumbein and Giele, 1991; Wright, 1994).

Most of the red pigment in the Goose Egg Formation is in intergranular clay cement. The red pigment supports in clay supports that this pigmentation formed from the weathering of iron-rich minerals and incorporation of that iron, in an oxidized form, into clay minerals during weathering. The red pigment in sediments is primarily derived from the presence of iron oxides like hematite $\left(\mathrm{Fe}_{2} \mathrm{O}_{3}\right)$ and oxyhydroxides like goethite $(\mathrm{FeOOH})$ incorporated into and staining red clays. Those clays are layered aluminosilicates formed from iron-rich minerals' instertial alteration, like hornblende to iron-rich montmorillonite (Walker, 1967b). Small amounts of iron oxides or oxyhydroxides minerals with low total iron concentrations, between $2.5 \%$ and $3.5 \%$, may result in bright red pigmentation after surface weathering and burial (Dorsey, 1926; Walker, 1967b, 1974; Schwertmann and Taylor, 2018). The red pigment is predominantly in the muddy lamina, pedogenic mud aggregates, and clays between grains. This textural evidence suggests an in situ origin for the red pigmentation, not that pigmentation was transported. Before the 1970s, red beds were thought to be transported sediment from humid upland soils. Early models for red bed formation presupposed that red beds formed through the transportation and preservation of upland soils formed in hot and humid climates. However, later observation demonstrated that red beds form predominately from in-situ surface weathering or eolian grain-impacts and the pigmentation can only be preserved if the environment is near-surface and oxidizing well into the burial process (Walker, 1967b, 1967a, 1974; El-Baz, 1986; Bowen et al., 2013). It is also possible that red iron oxides formed as iron oxide cements directly precipitating from groundwater (Bowen et al., 2012). However, none of the intergranular cement is opaque massive iron oxide cement that would be diagnostic of this environment.

Gypsum exposed at the surface has evidence of recrystallization and is inappropriate for some chemical or isotopic studies that could be used to interpret depositional conditions. Some of the carbonate in the Goose Egg also has neomorphic textures. Any future geochemical studies of the carbonates should be made with caution, only after petrographic confirmation of unaltered textures of in situ carbonate precipitates. Particular caution must be used with $\mathrm{Sr}^{87} / \mathrm{Sr}^{86}$ whole-rock isotope studies in recrystallized rocks. The Goose Egg carbonates are not candidates for dating with $\mathrm{Sr}^{87} / \mathrm{Sr}^{86}$ as they are not unambiguously marine or unambiguously unaltered. 


\section{Was the Goose Egg Deposited in and Acid Environment}

Acid saline lake systems are an important constituent of central Pangea's Permian red beds, recording extreme geochemical conditions and warm, arid climate (Benison et al., 1998; Zambito and Benison, 2013; Sephton et al., 2015). This study cannot resolve if some of the saline lake deposits of the Goose Egg Formation are part of these acidic environments. The Goose Egg Formation was deposited in environments similar to the penecontemporaneous Opeche Shale and the Nippewalla Group (Benison and Goldstein, 2000, 2001). The Opeche Shale consists of red mudstones in outcrop in the Black Hills of South Dakota and red mudstones and bedded and displacive halite in the Williston Basin subsurface. The Nippewalla Group includes red bed mudstones, rare red sandstones, bedded gypsum in outcrops in Kansas and Oklahoma, bedded halite, and displacive halite gypsum in the subsurface of western Kansas. Fluid inclusion studies showed that the bedded halite and the displacive halite in the Opeche Shale and Nippewalla Group precipitated from extremely acid (less than $\mathrm{pH}$ 1) lakes and groundwaters, respectively (Benison et al., 1998). The Goose Egg Formation likely represents an extension of the continental environments of the Opeche Shale and Nippewalla Group into Wyoming. Unlike the Opeche Shale and Nippewalla Group, the Goose Egg Formation has no positive evidence of acidity. Though high acidic environments may encourage red beds' formation through iron oxides' direct precipitation, it is not required. Iron oxides and oxyhydroxides can form and be preserved in a wide variety of $\mathrm{pH}$ and Eh conditions, including those of common oxygenated desert groundwater (Walker, 1967b, p. 362). None of the Goose Egg Formation's intergranular cement is massive iron oxide cement that may indicate direct precipitation from acidic waters.

Unlike the Opeche Shale and Nippewalla Group, the Goose Egg Formation has carbonate units and carbonate cement. Although carbonate lithoclasts and transported carbonate can persist in acidic aqueous environments, new coated grains, skeletal grains, and abiotic precipitation are precluded. The peloids of the Goose Egg Formation are non-diagnostic and may originate as pellets, as lithoclasts, reworking of precipitated carbonate or lithoclasts, or as highly micritized skeletal or coated grains. As such, peloids are non-diagnostic. Microfossils are suggestive that organisms with carbonate hard parts could survive. However, this is not definitive as they could be silica hard parts replaced later. The presence of carbonate mud in the laminated carbonate lithofacies is highly suggestive of direct carbonate precipitation, either inorganically or from the remains of organisms settling out of the water column. Due to some recrystallization, a differentiative origin of the carbonate mud cannot be established. However, the preponderance of the evidence is suggestive that at least some of the Goose Egg environments were not acidic.

Post-depositional carbonate is also present in the Goose Egg Formation. Though the Goose Egg 
has no clear caliche horizons, carbonate cement is pervasive. The timing of this cementation cannot be established, but it may have formed as soon as early pedogenesis. Blocky pore-filling calcite cement (e.g., Fig. 5G) are common in early groundwater-formed calcretes (Alonso-Zarza and Wright, 2010, p. 232). Soils formed from carbonates in the Goose Egg Formation, indicating that they were carbonates exposed at the surface. For example, terra rosa forms from the dissolution of carbonate at the surface and insoluble residue accumulation (Isphording et al., 1995; Saltzman and Sedlacek, 2013). These carbonates' presence and preservation indicate that conditions were not acidic for at least part of Goose Egg time.

The Goose Egg Formation could have been deposited, partially or wholly, in an environment with acidic surface or groundwater. The similarity of the physical environments to the Opeche Shale and Nippewalla Group to the Goose Egg Formation suggests that all three units may have been deposited as part of the same contemptuous environment. Additionally, acidic environments should always be considered with red beds. Red beds are red because iron has been freed from iron-bearing minerals like biotite and amphiboles, and either (1) substituted for aluminum in layered phyllosilicate clay minerals or (2) directly precipitated as crystals of iron oxide crystals that grow in pores and directly connect particles (Lindsay, 1988; Schwertmann and Taylor, 2018). The $\mathrm{pH}$ is of prime importance in this system. Firstly, protolysis is the primary mechanism for the dissolution of iron-rich primary minerals, and lower $\mathrm{pH}$ will result in more chemical weathering and more iron released into the system (Murad and Fischer, 1988). If positive feedback is established in an oxidizing environment where the iron released is oxidized from the common mineral-form ferrous iron to ferric hydroxide and hydrogen ions promoting a decreasing $\mathrm{pH}$ (Brinkman, 1970; Breemen, 1988; Van and De, 2002). Rapid release of Fe(III) ions in low-organic environments can either rapidly form ferrihydrate, a metastable amorphous hydrated iron oxide, or goethite (Houten and Franklyn, 1968; Davey et al., 1975; Wang et al., 1993). At pH below 4, hematite can directly precipitate (Lindsay, 1988). Ferrihydrate can slowly organize into hematite or dissolve and reprecipitate as goethite. Once reaching hematite or goethite, the Fe(III) is stable to changes in environmental oxidation state and only reduced to $\mathrm{Fe}$ (II) by microbial reduction or complexation by the decay of organic material (Schwertmann, 1988). There is no definitive evidence precluding acid environments, particularly if carbonates were transported into the system. However, the precipitation and preservation of iron oxide cement are suggestive of acidic involvement. 


\section{Implications for Climate and Environments of Pangea}

Although the age of the Goose Egg Formation remains poorly defined, it fits into a larger system of central Pangean environments in the late Permian and Early Triassic, characterized by high temperatures (Tabor, 2013 and references therein), high fine-grained sediment flux (Kessler et al., 2001 and references therein; Soreghan et al., 2008a), and extreme acid saline ephemeral lakes (Benison et al., 1998; Andeskie et al., 2018). This study extends those environments from western to eastern Wyoming. The Goose Egg Formation was deposited in an arid and possibly hot climate.

Saline lake deposits with frequent exposure and significant gypsum accumulation indicate high evaporation rates in arid climates. Eolian deposition is common in arid climates. The accumulation of red beds is seemingly associated with high-temperature environments like tropical soils, dryland soils, and acid saline lakes and mudflats (Walker, 1967b, 1967a, 1974; Buol and Eswaran, 1999; Benison et al., 2007; Bowen et al., 2008) where the formation of hydrous ferric oxyhydroxide seems to requires temperatures at least above $25^{\circ} \mathrm{C}$, biological mediation, or both (Schwertmann and Taylor, 2018; Stoffregen et al., 2019). In modern soils, warm regions are dominated by hematite (or predecessor ferric oxyhydroxides), resulting in red soil color. Soils in colder regions are dominated by goethite precipitation, forming brown or yellowish soils (Schwertmann, 1988). However, this is non-diagnostic as low $\mathrm{pH}$, or high Eh can favor ferric oxyhydroxide or even direct hematite precipitation (Schwertmann, 1988; Ferris et al., 1989; Bowen et al., 2012).

The presence of large amounts of fine-grained yet chemically immature sediment is a conundrum. Loess deposits cover over 10\% of the Earth's surface, mostly derived from end-glaciation wind-blown sediment (Tsoar and Pye, 1987). The accumulation of the amounts of fine sediment in the Goose Egg Formation and other Pangean red beds requires (1) mechanisms for the generation of chemically immature silt; (2) physical weathering, transportation, and winnowing of that silt to a uniform or bimodal grain size; and (3) a mechanism for sequestering the silt on the landscape and subsequent burial. Many effective silt generating mechanisms have been proposed, including glacial grinding, salt or frost weathering, fluvial or eolian comminution (Wright, 2001, and references therein). Extensive low-latitude glaciation has been suggested as a mechanism for generating extensive chemically immature Permian silt (Soreghan et al., 2008b, 2008a; Giles et al., 2013). However, this mechanism must be reconciled with the timing of onset of catastrophic greenhouse conditions in the middle and late Permin and Early Triassic (Kutzbach and Gallimore, 1989; Dickins, 1993; Wignall, 2001; Kidder and Worsley, 2004; Tabor, 2013; Zambito 
and Benison, 2013; Benison et al., 2014). Detailed sub-micron electron microscopy of the Goose Egg siliciclastic rocks could help to resolve its pre-depositional sediment pathways. However, the twin mysteries of the origin of Permian-Triassic dust and the origin of widespread acid-saline systems require a global collaborative approach.

\section{Stratigraphic Implications}

Since Darton (1906), the relationships of the Permian and Triassic rocks of western and central Wyoming have been highly debated (see Thomas, 1934 for details of pre-1930s work). It is uncontroversial that the Goose Egg Formation lies unconformably above Minnelusa Sandstone (locally Tensleep, Casper, or Hartville) and conformably below the Red Peak Formation of the Chugwater Group (Thomas, 1948; Love, 1954; Burk et al., 1956; Maughan, 1964; Lane, 1973). The Goose Egg Formation was physically distinguished from the Chugwater Group's Red Peak Formation by a subtle color change to a "darker, richer red" (Burk et al., 1956) in the Goose Egg Formation. The intellectual foundation of this distinction, however, was twofold: (1) that the red beds of the Goose Egg Formation were being linked to the red beds of the Phosphoria Formation, and (2) that before 1956 it was unclear that a single formation rank unit could transgress epoch, periods, or eras. Rodgers (1954) of the American Stratigraphic Commission clarified that " $[\mathrm{r}]$ ock-stratigraphic units are lithogenetic units; that is, material rock units defined by genesis or origin, as expressed by lithology, and without reference to time." Thus, there is no logical reason to separate the Permian Goose Egg Formation from the Triassic Red Peak Formation.

The lateral stratigraphic correlations among the Goose Egg Formation and adjacent sedimentary rocks have not been well established and is heavily reliant on a model put forth by Thomas (1934, p. 1675). According to Thomas, limestones from what would later be consolidated into the Goose Egg Formation would be linked to the Phosphoria Formation by an assemblage of fossils, including bryozoans, gastropods, and brachiopods in "considerable abundance." According to Thomas, this fossiliferous unit, the Evary Tonge Member of the Phosphoria Formation, is "approximately 325 feet above the base of the Phosphoria Fm." in the Rattlesnake Hills. Thomas reports that this section of the Phospheria Formatiow comprises mostly red beds, just 40 kilometers from "normal" Phospheria rocks. This connection to the Phospheria Formation would lead to a model where all Goose Egg carbonate units were eastward projections of the Phosphoria (Fig. 18A). The correlation between the fossiliferous limestones at the Rattlesnake Hills must be considered tenuous to limestone units within the Goose Egg in this study area, where the only fossils observed were microfossils of indeterminate origin.

Paull and Paull (1990) disentangled the Dinwoody Formation from the Goose Egg Formation 
in the Owl Creek Mountains, breaking one of the tenuous ties between the Goose Egg and the marine rocks to the west. Lane (1973) also tried and failed to establish a correlation between the Goose Egg Formation and the Dinwoddy or Phosphoria Formation using electric logs. Lane concluded that the Goose Egg was a time- equivalent but distinct basin from the Phospheria Formation (Fig. 18B). The "distinct and persistent" members of the Goose Egg Formation were not eastward extensions of the Phosphoria and that " $[\mathrm{t}]$ his difference is more than just a matter of semantics; it is both physically incorrect and genetically misleading to imply that the Phosphoria sea once extended into eastern Wyoming. It did not." There is no recorded transition from thin limestones in a unit with mostly continental red beds to almost entirely marine limestone of the Phosphoria Formation. No westward thicking of units, no progression of facies that would indicate deeper water to the west, and no unambiguously marine rocks were observed. The Goose Egg Formation has no evidence of a marine transgression.

Stratigraphic correlations and assignments based on being in a similar stratigraphic position are questionable in continental settings. A continental deposition environment calls into question the long-distance correlations of red bed -hosted carbonate units of the Goose Egg Formation into North Dakota, South Dakota, Kansas, and Colorado. The similar stratigraphic position of carbonate units or similar progressions of lithofacies is insufficient evidence for correlation. Though lacustrine facies can cover a large area, it is unlikely that a thin depositional unit can be traced for more than $400 \mathrm{~km}$. It is much more likely that many unrelated thin carbonates and gypsum units were deposited in an overlapping mosaic of lacustrine and adjacent continental environments (Fig. 18C) and that few Goose Egg Formation units are truly correlative over long distances. The nature of brine evolution in saline lakes (Fig. 17) also makes it possible that the same succession of lithologies, resulting from increasing evapoconcentration, could result in the same succession of lithologies being repeated in unrelated units (Eugster and Hardie, 1978). An approach to correlations based on surrounding units is suggested and perhaps focuses on paleosols and other intra-lacustrine deposits, an approach that has proved fruitful in correlations of interfluvial deposits (Shanley and McCabe, 1994).

The future reorganization to include the Goose Egg Formation as part of the overlying Chugwater Group must be considered (Fig. 1). There are many similarities between the Goose Egg and the Red Peak Formation of the Chugwater Group. A subtle color change is the main difference, yet it seems insufficient to differentiate the two formations. If individual gypsum or limestone units are not correlative, as seems the case, then the stratigraphic nomenclature's proliferation of formation-rank is unhelpful. The Goose Egg Formation is a mappable unit and genetically related to the overlying Chugwater Group; it is questionable if individual carbonate and gypsum units 


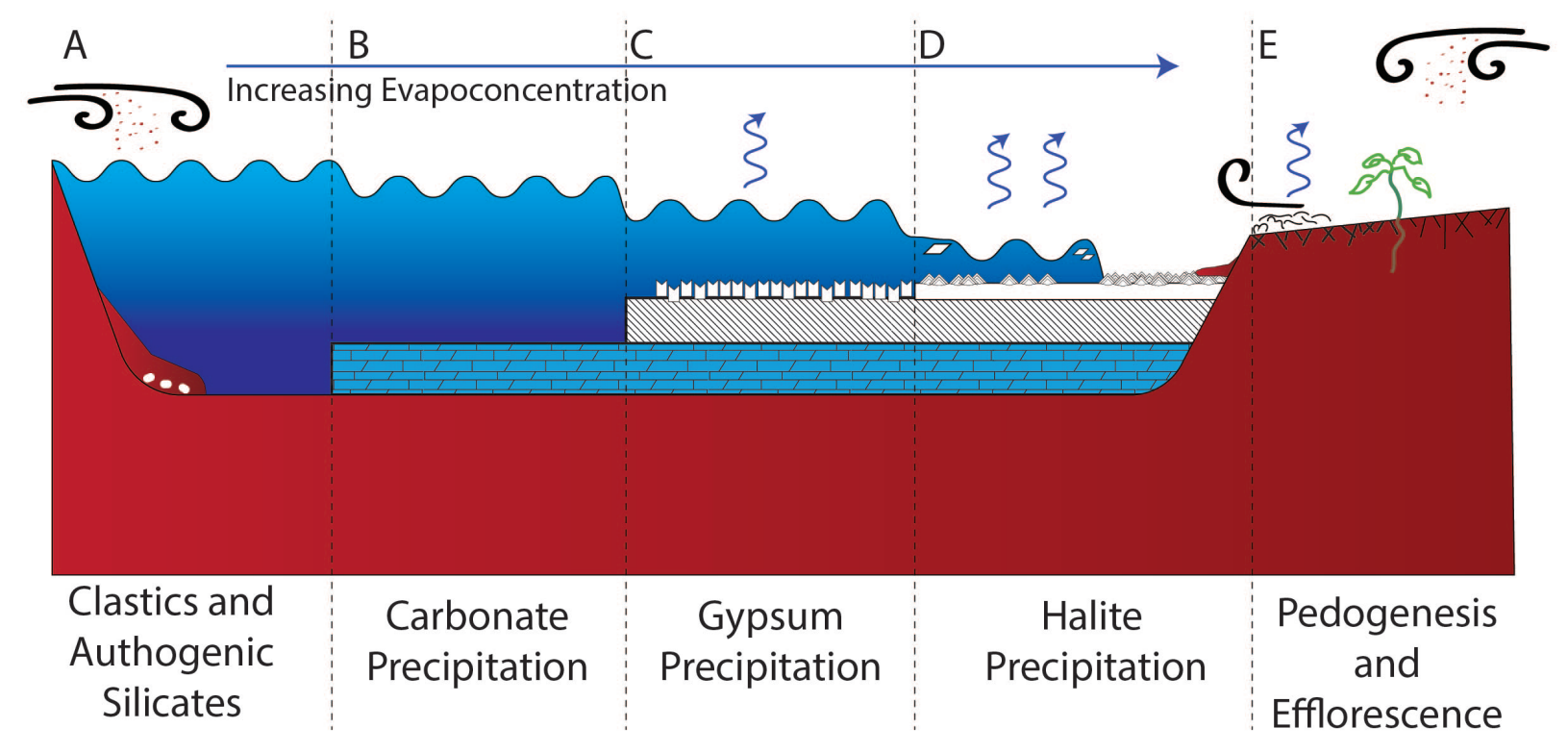

$\mathrm{Na}-\mathrm{Ca}-\mathrm{Mg}-\mathrm{Cl}-\mathrm{HCO}_{3}-$ $\mathrm{CO}_{3}-\mathrm{SO}_{4}$

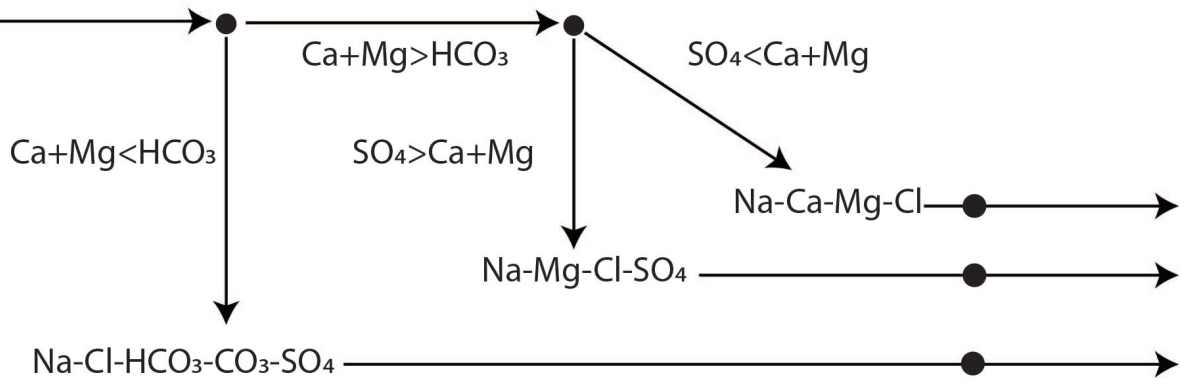

Brine evolution pathways (after Hardie and Eugster 1970)

Fig. 17: Diagrammatic model for brine evolution. Closed basin brine evolution models after Hardie (1970). (A) Marine, meteoric, or hydrothermal waters acquire solutes from interactions with soil and bedrock. Additional solutes may be acquired from aerosol or dry deposition and sediment input into the system. Here, consider two brines: a $\mathrm{Na}-\mathrm{Ca}-\mathrm{Mg}-\mathrm{Cl}-\mathrm{HCO}-\mathrm{SO} 4$ brine and a Na-Ca-Mg-Cl-SO4 brine. (B) When evaporation exceeds inputs in a closed basin, the water will increase in concentrations of solutes. The presence of bicarbonate will govern the precipitation of carbonates and influence the precipitation of iron phase minerals. Sepiolite, dolomite, and other clays may precipitate in addition to calcite. Clastic inputs remain an important accumulation source, particularly where large amounts of atmospheric dust are in circulation. (C) Gypsum can precipitate when $\mathrm{Ca}$ and $\mathrm{Mg}$ ions are in greater concentrations than alkalinity (bicarbonate) or when sufficient sulfate is present. Gypsum can accumulate as a precipitate from the water column or as bottom growth crystals. The chemical complexity of brines may increase, and clays, iron minerals, or magnesium silicates may precipitate. (D) Saline minerals precipitation will occur with continued evapoconcentration and a many-fold increase in solute concentration. Saline minerals can be diverse, but halite is the most common. Desiccation forms large polygons, teepee structures, and efflorescent crusts. Sediment may still be introduced into the lake basin 
as sheet flow deposits. (E) An efflorescent crust forms with groundwater evaporation or as the final evaporation of surface water, forming many complex saline minerals built up into a rough and often polyhedral topography. Crusts can form in desiccated lakes or adjacent to extant lakes on mudflats. Efflorescent and surrounding low vegetation crust can trap sediment, particularly wind-blown silt. Efflorescent crusts can also be blown by the wind and contribute to salute accumulations in nearby lakes. This "solute recycling" can also occur when desiccated saline pans are flooded or when subsurface salts are dissolved, creating a positive feedback loop encouraging the development of saline minerals.

of the Goose Egg Formation can be mapped beyond the purely local scale. Besides, the linkage between the Goose Egg Formation and the Phosphoria Formation must be revisited, particularly in the Rattlesnake Hills. Additionally, a detailed study of individual carbonate beds focusing on the environment of deposition and robust correlations are indicated.

\section{CONCLUSIONS}

Detailed sedimentological observation of the Goose Egg Formation of Wyoming indicates that it was deposited in a perennial carbonate- and gypsum-producing saline lakes, ephemeral gypsum, and saline mineral producing saline lakes and salt pans, and associated terrestrial environments of deposition. Other red bed facies formed in dry mudflats with sheet sand deposits, wet mudflats with efflorescent crusts capturing wind-blown silt, and laminated siltstones deposited in saline lakes. Other saline lake deposits include bottom growth and possibly cummulate or displacive gypsum, laminated carbonate, and wavy carbonate. Saline lake deposits have extensive evidence for frequent desiccation.

There is no evidence for marine or marginal marine environments of deposition or transgressive-regressive cycles. The depositional environments are closely related to those described for the Opeche Shale (Benison and Goldstein, 2000) and likely represent an extension of those environments into Wyoming. However, the Goose Egg Formation has inconclusive evidence to ascertain if it was deposited in an acid saline environment like the Opeche Shale and Nippwalla Group. A core, specially drilled to preserve evaporite minerals, would be required to fully resolve the depositional environment.

This study provides sedimentological caution when attempting to correlate any units of the Goose Egg Formation over long distances. Neither fluvial nor lacustrine facies produce units that are laterally extensive and correlatable over hundreds of kilometers. Additional fieldwork and petrographic observations, aided by remote sensing and a reexamination of more modern wireline logs, may be required to resolve the relationships between the Goose Egg Formation and western rock units. 


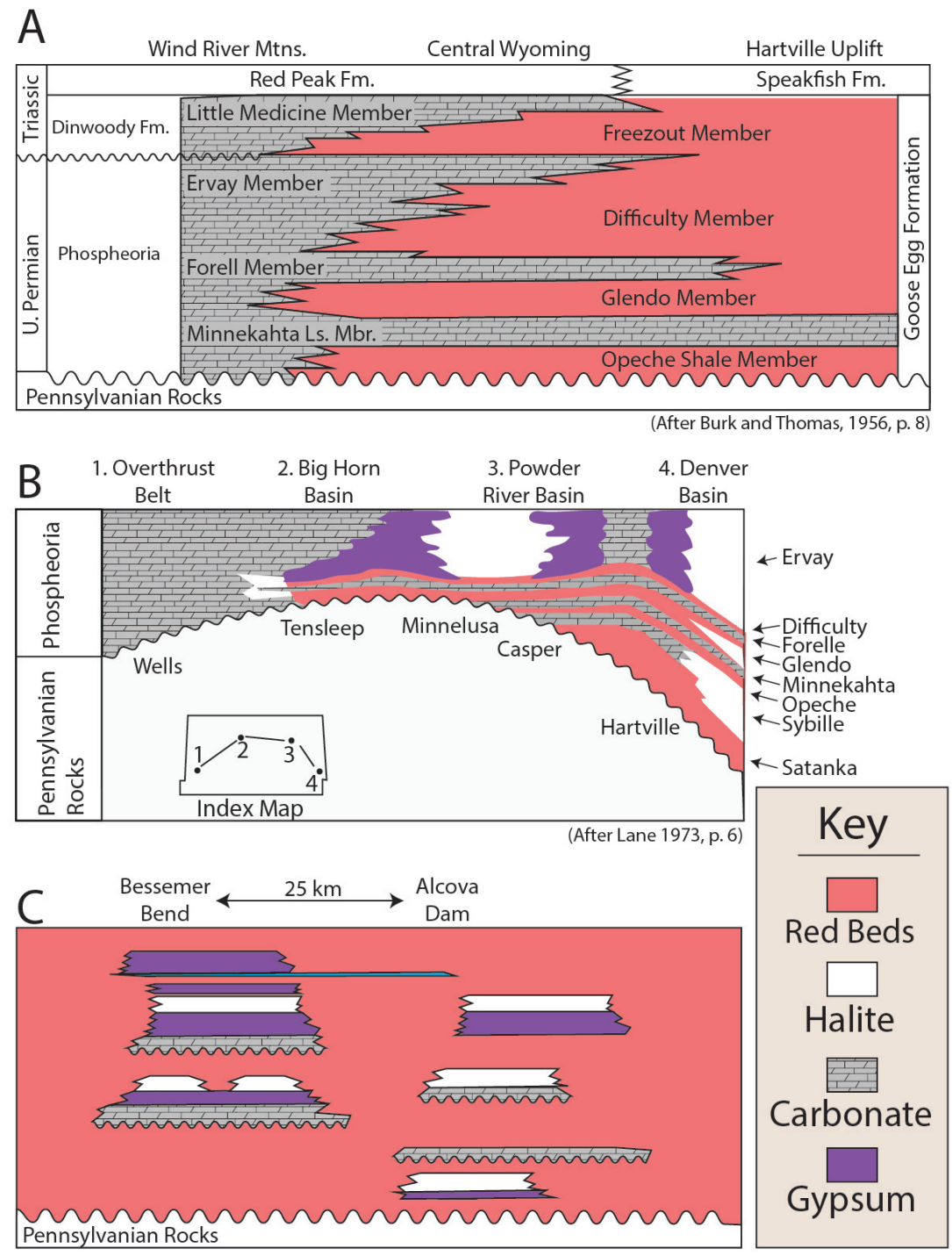

Fig. 18: Regional correlations cartoon. The Goose Egg has been an enigma since it was first mentioned by Darton (1906). Two models have been proposed for the relationship between the Goose Egg and the Phosphoria and Dinwoddy formations to the west. (A) Thomas (1934), and Burke and Thomas (1956) proposed a model for the Goose Egg where the carbonates and gypsum units of the Goose Egg were eastward extensions of tongues of the Phosporia Formation. (B) Lane (1973) used an extensive database of electric logs and concluded that the various members of the Goose Egg Formation could not be correlated to the Phosphoria Formation. Lane also recognized large accumulations of salt in the subsurface. Both diagrams have been simplified. (C) A diagrammatic sketch of possible stratigraphic relationships within the Goose Egg in a continental model. Terrestrial red beds and lacustrine environments are not easily correlated between outcrops, although they are extensive enough to cover tens of square miles. Some saline lakes in the modern maybe thousands of square kilometers; for example, the Great Sale Lake is over $4000 \mathrm{~km} 2$. Significant amounts of saline minerals are present and widely distributed in the subsurface, further complicating correlations. 
The Goose Egg Formation is an important formation for understanding the late Permian and Early Triassic paleogeography and climate. It is part of a larger Permian-Triassic red beds system that indicates a global weirding that produces extreme sedimentary environments over Pangea's wide swath. Of particular interest is the causes and consequences of large accumulations of fine-grained, wind-blown, silt-sized, and smaller clastic sediment. This study of the Goose Egg Formation extends the environments impacted by this phenomenon.

\section{REFERENCES}

Abrantes, F.R., Nogueira, A.C.R., and Soares, J.L., 2016, Permian paleogeography of west-central Pangea: Reconstruction using sabkha-type gypsum-bearing deposits of Parnaíba Basin, Northern Brazil: Sedimentary Geology, v. 341, p. 175-188, doi:10.1016/j.sedgeo.2016.06.004.

Achauer, C.W, 1987, Marine carbonate embayment system in an eolian dune terrain, Permian upper Minnelusa Formation, Rozet area, Powder River basin, Wyoming: AAPG Bulletin, v. 71, p. 524.

Ahlbrandt, T.S., and Fryberger, S., 1981, Sedimentary features and significance of interdune deposits: SEPM Special Publication, p. 293-314.

Alonso-Zarza, A.M., and Wright, V.P., 2010, Calcretes, in Developments in Sedimentology, Elsevier, v. 61, p. 225-267.

Andeskie, A.S., Benison, K.C., Eichenlaub, L.A., and Raine, R., 2018, Acid-saline-lake systems of the Triassic Mercia Mudstone Group, County Antrim, Northern Ireland: Journal of Sedimentary Research, v. 88, p. 385-398, doi:10.2110/jsr.2018.14.

Baars, D.L., 1961, Permian system of Colorado Plateau: AAPG Bulletin, v. 46, p. 149-218.

Bell, C.M., 1989, Saline lake carbonates within an Upper Jurassic-Lower Cretaceous continental red bed sequence in the Atacama region of northern Chile: Sedimentology, v. 36, p. 651663, doi:10.1111/j.1365-3091.1989.tb02091.x.

Benison, K.C., 2019. The physical and chemical sedimentology of two high-altitude acid salars in Chile: sedimentary processes in an extreme environment. Journal of Sedimentary Research, v. 89, no.2, p.147-167.

Benison, K.C., Bowen, B.B., Oboh-Ikuenobe, F.E., Jagniecki, E.A., LaClair, D.A., Story, S.L., Mormile, M.R., and Hong, B.-Y., 2007, Sedimentology of acid saline lakes in Southern 
Western Australia: newly described processes and products of an extreme environment: Journal of Sedimentary Research, v. 77, p. 366-388, doi:10.2110/jsr.2007.038.

Benison, K.C., and Goldstein, H.R., 2001, Evaporites and siliciclastics of the Permian Nippewalla Group of Kansas, USA: a case for non-marine deposition in saline lakes and saline pans: Sedimentology, v. 48, p. 165-188, doi:https://doi.org/10.1046/j.1365-3091.2001.00362.x.

Benison, K.C., and Goldstein, R.H., 2002, Recognizing acid lakes and groundwaters in the rock record: Sedimentary Geology, v. 151, p. 177-185, doi:10.1016/S0037-0738(02)00155-0.

Benison, K.C., and Goldstein, R.H., 2000, Sedimentology of ancient saline pans: an example from the Permian Opeche Shale, Williston Basin, North Dakota, U.S.A.: Journal of Sedimentary Research, v. 70, p. 159-169, doi:10.1306/2dc40907-0e47-11d7$8643000102 \mathrm{c} 1865 \mathrm{~d}$.

Benison, K.C., Goldstein, R.H., Wopenka, B., Burruss, R.C., and Pasteris, J.D., 1998, Extremely acid Permian lakes and ground waters in North America: Nature, v. 392, p. 911-914, doi:10.1038/31917.

Benison, K.C., Zambito, J.J., and Knapp, J., 2015, Contrasting siliciclastic-evaporite strata in subsurface and outcrop: an example from the Permian Nippewalla Group of Kansas, U.S.A: Journal of Sedimentary Research, v. 85, p. 626-645, doi:10.2110/jsr.2015.43.

Benison, K.C., Zambito, J.J., Soreghan, G.S., Soreghan, M.J., Foster, T.M., Kane, M.J., Dubois, M.K., Watney, W.L., and Tollefson, J., 2014, Permian red beds and evaporites of the Amoco Rebecca K. Bounds core, Greeley County, Kansas: implications for science and industry, in Kansas Geological Survey and Kansas Geological Society ed., Mid-continent core workshop: from source to reservoir to seal. Mid-Continent Section American Association of Petroleum Geologists, Kansas Geological Survey, Wichita, Kansas, p. 9-14.

Benton, M., Cook, E., and Turner, P., 2002, Permian and Triassic red beds and the Penarth Group of Great Britain: Geological Conservation Review Series, p. 337.

Blowes, D.W., Ptacek, C.J., Jambor, J.L., and Weisener, C.G., 2003, The geochemistry of acid mine drainage: Environmental geochemistry, v. 9, p. 149-204.

Bowen, B.B., Benison, K.C., Oboh-Ikuenobe, F.E., Story, S., and Mormile, M.R., 2008, Active hematite concretion formation in modern acid saline lake sediments, Lake Brown, Western Australia: Earth and Planetary Science Letters, v. 268, p. 52-63, doi:https://doi. org/10.1016/j.eps1.2007.12.023.

Bowen, B.B., Benison, K.C., Story, S., Grotzinger, J., and Milliken, R., 2012, Early diagenesis 
by modern acid brines in Western Australia and implications for the history of sedimentary modification on Mars: Mars Sedimentology, SEPM Special Publication, v. 102, p. 229-252.

Bowen, B.B., Story, S., Oboh-Ikuenobe, F., and Benison, K.C., 2013, Differences in regolith weathering history at an acid and neutral saline lake on the Archean Yilgarn Craton and implications for acid brine evolution: Chemical Geology, v. 356, p. 126-140, doi:10.1016/j. chemgeo.2013.08.005.

Branson, E.B., 1927, Triassic-Jurassic "red beds" of the Rocky Mountain region: The Journal of Geology, v. 35, p. 607-630, doi:10.2307/30063032.

Breemen, N., 1988, Redox processes of iron and sulfur involved in the formation of acid sulfate soils, in Stucki, J. W., Goodman, B. A., \& Schwertmann, U. eds., Iron in soils and clay minerals, Springer Netherlands, p. 825-841, doi:10.1007/978-94-009-4007-9_25.

Breuning-Madsen, H., and Awadzi, T.W., 2005, Harmattan dust deposition and particle size in Ghana: Catena, v. 63, p. 23-38, doi:10.1016/j.catena.2005.04.001.

Brinkman, R., 1970, Ferrolysis, a hydromorphic soil forming process: Geoderma, v. 3, p. 199 206, doi:10.1016/0016-7061(70)90019-4.

Buol, S.W., and Eswaran, H., 1999, Oxisols: Advances in Agronomy, v. 68, p. 151-195, doi:10.1016/S0065-2113(08)60845-7.

Burk, C.A., Thomas, H.D., 1956, The Goose Egg Formation (Permo-Triassic) of eastern Wyoming: Report of Investagations.

Chakraborty, T., and Sarkar, S., 2005, Evidence of lacustrine sedimentation in the Upper Permian Bijori Formation, Satpura Gondwana basin: Palaeogeographic and tectonic implications: Journal of Earth System Science, v. 114, p. 303-323, doi:10.1007/BF02702952.

Chu, G., Sun, Q., Zhaoyan, G., Rioual, P., Qiang, L., Kaijun, W., Han, J., and Liu, J., 2009, Dust records from varved lacustrine sediments of two neighboring lakes in northeastern China over the last 1400 years: Quaternary International, v. 194, p. 108-118, doi:10.1016/j. quaint.2008.08.005.

Cole, R.D., Mullen, C.E., 1992, Reservoir characterization of Tensleep Sandstone (Pennsylvanian-Permian), South Casper Creek Field, Natrona County, Wyoming: AAPG Bulletin, v. 76, p. 1257.

Darton, N.H., 1906, Geology of the Bighorn Mountains. No. 51, US Government Printing Office. Darton, N., 1908, Paleozoic and Mesozoic of central Wyoming: Bull. Geol. Soc. America, v. 19, 
p. $403-74$.

Davey, B.G., Russell, J.D., and Wilson, M.J., 1975, Iron oxide and clay minerals and their relation to colours of red and yellow podzolic soils near Sydney, Australia: Geoderma, v. 14, p. 125-138, doi:10.1016/0016-7061(75)90071-3.

Dickins, J.M., 1993, Climate of the Late Devonian to Triassic: Palaeogeography, Palaeoclimatology, Palaeoecology, v. 100, p. 89-94, doi:10.1016/0031-0182(93)90034-G.

Dorsey, G.E., 1926, The Origin of the color of red beds: The Journal of Geology, v. 34, p. 131143, doi:10.2307/30057891.

Dunham, R.J., 1962, Classification of carbonate rocks according to depositional textures: in Ham, William Eugene, ed. Classification of carbonate rocks: a symposium: American Association of Petroleum Geologists Memoir, v. 1, p. 108-121

Ekes, C., 1993, Bedload-transported pedogenic mud aggregates in the Lower Old Red Sandstone in southwest Wales: Journal - Geological Society (London), v. 150, p. 469-471, doi:10.1144/gsjgs.150.3.0469.

El-Baz, F., 1986, On the Reddening of Quartz Grains in Dune Sand, in Physics of desertification, Springer Netherlands, p. 191-209, doi:10.1007/978-94-009-4388-9_14.

El-Baz, F., 1978, The meaning of desert color in earth orbital photographs: Photogrammetric Engineering and Remote Sensing, v. 44, no.1, p. 69-75.

Eugster, H.P., 1980, Geochemistry of evaporitic lacustrine deposits: Annual Review of Earth and Planetary Sciences, v. 8, p. 35-63, doi:10.1146/annurev.ea.08.050180.000343.

Eugster, H.P., and Hardie, L.A., 1978, Saline lakes, in Lakes, Springer New York, p. 237-293, doi:10.1007/978-1-4757-1152-3_8.

Eugster, H.P., and Jones, B.F., 1979, Behavior of major solutes during closed basin- lakes brine evolution.: American Journal of Science, v. 279, p. 609-631, doi:10.2475/ajs.279.6.609.

Faulkner, G.L., 1956, Subsurface stratigraphy of the pre-Niobrara formations along the western margin of the Powder River Basin, Wyoming: , p. 35-42.

Ferris, F.G., Tazaki, K., and Fyfe, W.S., 1989, Iron oxides in acid mine drainage environments and their association with bacteria: Chemical Geology, v. 74, p. 321-330.

Fisher, J.A., Nichols, G.J., and Waltham, D.A., 2007, Unconfined flow deposits in distal sectors of fluvial distributary systems: Examples from the Miocene Luna and Huesca Systems, 
northern Spain: Sedimentary Geology, v. 195, p. 55-73, doi:10.1016/j.sedgeo.2006.07.005.

Foster, T.M., Soreghan, G.S., Soreghan, M.J., Benison, K.C., and Elmore, R.D., 2014, Climatic and paleogeographic significance of eolian sediment in the Middle Permian Dog Creek Shale (Midcontinent U.S.): Palaeogeography, Palaeoclimatology, Palaeoecology, v. 402, p. 12-29, doi:10.1016/j.palaeo.2014.02.031.

Fryberger, S.G., 1990, Chapter 4: Eolian stratification: in Fryberger, S.G., Krystinik, L.F. and Schenk, C.J., eds.. Modern and ancient eolian deposits: Petroleum exploration and production: Rocky Mountain section. SEPM, Denver, Colorado, p. 29-40.

Gierlowski-Kordesch, E.H., 2010, Lacustrine carbonates: Developments in Sedimentology, Elsevier, v. 61, p. 1-101, doi:10.1016/S0070-4571(09)06101-9.

Gierlowski Kordesch, E.H., and Gibling, M.R., 2012, Pedogenic mud aggregates in rift sedimentation: Special Publications of SEPM.

Giles, J.M., Soreghan, M.J., Benison, K.C., Soreghan, G.S., and Hasiotis, S.T., 2013, Lakes, loess, and paleosols in the Permian Wellington Formation of Oklahoma, U.S.A.: implications for paleoclimate and paleogeography of the midcontinent: Journal of Sedimentary Research, v. 83, p. 825-846, doi:10.2110/jsr.2013.59.

Goldberg, K., Morad, S., Al-Aasm, I.S., and De Ros, L.F., 2011, Diagenesis of Paleozoic playa-lake and ephemeral-stream deposits from the Pimenta Bueno Formation, Siluro-Devonian (?) of the Parecis Basin, central Brazil: Journal of South American Earth Sciences, v. 32, p. 58-74, doi:10.1016/j.jsames.2011.05.002.

Goldstein, R.H., 2001, Clues from fluid inclusions: Science, v. 294, p. 1009-1011, doi:10.1126/ science. 1066322.

Hammer, U.T., and Dumont, H.J., 1986, Saline lake ecosystems of the world: Springer, 640 p.

Hardie, L.A., 1984, Evaporites: marine or non-marine? American Journal of Science, v. 284, p. 193-240, doi:10.2475/ajs.284.3.193.

Hardie, L.A., Smoot, J.P., and Eugster, H.P., 2009, Saline lakes and their deposits: a sedimentological approach, in Matter, A. and Tucker, M.E. eds., Modern and Ancient Lake Sediments, Blackwell Publishing Ltd., v. 2, p. 7-41, doi:10.1002/9781444303698.ch2.

Houten, V., and Franklyn, B., 1968, Iron oxides in red beds: Geological Society of America Bulletin, v. 79, p. 399-416, doi:10.1130/0016-7606(1968)79[399:IOIRB]2.0.CO;2.

Hussain, M., and Warren, J.K., 1989, Nodular and enterolithic gypsum: the "sabkha-tization" 
of Salt Flat Playa, west Texas: Sedimentary Geology, v. 64, p. 13-24, doi:10.1016/00370738(89)90081-X.

Isphording, W.C., Bundy, M.E., George, S.M., and Jackson, R.B., 1995, Depositional interpretation of limestone insoluble residues from modern and ancient carbonate rocks, Caribbean and Southern United States: Gulf Coast Association of Geological Societies , v. 45, 285-291 p.

Jerolmack, D.J., Reitz, M.D., and Martin, R.L., 2011, Sorting out abrasion in a gypsum dune field: Journal of Geophysical Research: Earth Surface, v. 116, p. F02003, doi:10.1029/ 2010JF001821.

Jones, B., and Renaut, R.W., 2010, Calcareous spring deposits in continental settings, in Alonso-Zarza, A.M. and Tanner, L.H. eds., Developments in Sedimentology, Elsevier, v. 61, p. $177-224$.

Kelts, K., and Talbot, M., 1990, Lacustrine carbonates as geochemical archives of environmental change and biotic/abiotic interactions in M. M. Tilzer \& C. Serruya, Eds., Large lakes: ecological structure and function, p. 288-315, doi:10.1007/978-3-642-84077-7_15.

Kessler, J.L.P., Soreghan, G.S., and Wacker, H.J., 2001, Equatorial aridity in Western Pangea: Lower Permian loessite and dolomitic paleosols in northeastern New Mexico, U.S.A.: Journal of Sedimentary Research, v. 71, p. 817-832, doi:10.1306/2dc4096b-0e47-11d7$8643000102 \mathrm{c} 1865 \mathrm{~d}$.

Kidder, D.L., and Worsley, T.R., 2004, Causes and consequences of extreme Permo-Triassic warming to globally equable climate and relation to the Permo-Triassic extinction and recovery: Palaeogeography, Palaeoclimatology, Palaeoecology, v. 203, p. 207-237, doi:10.1016/S0031-0182(03)00667-9.

Kocurek, G., Carr, M., Ewing, R., Havholm, K.G., Nagar, Y.C.C., and Singhvi, A.K.K., 2007, White Sands Dune Field, New Mexico: Age, dune dynamics and recent accumulations: Sedimentary Geology, v. 197, p. 313-331, doi:10.1016/j.sedgeo.2006.10.006.

Krumbein, W.E., and Giele, C., 1991, Calcification in a coccoid cyanobacterium associated with the formation of desert stromatolites, in Wright, V.P. and Tucker, urice E. eds., Sedimentology, Blackwell Publishing Ltd., v. 26, p. 231-242, doi:10.1111/j.1365-3091.1979.tb00931.x.

Kutzbach, J.E., and Gallimore, R.G., 1989, Pangaean climates: megamonsoons of the megacontinent: Journal of Geophysical Research: Atmospheres, v. 94, p. 3341-3357, doi:10.1029/ JD094iD03p03341. 
Lane, D.W., 1973, The Phosphoria and Goose Egg Formations in Wyoming: Geological Survey of Wyoming, Preliminary Report No., p. 23.

Langford, R.P., Rose, J.M., and White, D.E., 2009, Groundwater salinity as a control on development of eolian landscape: An example from the White Sands of New Mexico: Geomorphology, v. 105, p. 39-49, doi:10.1016/j.geomorph.2008.01.020.

Last, W.M., 1990, Lacustrine dolomite - an overview of modern, Holocene, and Pleistocene occurrences: Earth-Science Reviews, v. 27, p. 221-263, doi:10.1016/0012-8252(90)90004-F.

Lindsay, W.L., 1988, Solubility and redox equilibria of iron compounds in soils, in Stucki, J. W., Goodman, B. A., \& Schwertmann, U. eds., iron in soils and clay minerals, Springer Netherlands, p. 37-62, doi:10.1007/978-94-009-4007-9_3.

Love, J.D., 1954, Tentative diagrammatic correlation of Tensleep, Amsden, Casper, and Hartville formations in Wyoming, in Wyoming Geol. Assoc. 9th Ann. Field Conf. Guidebook.

Lowenstein, T.K., and Hardie, L.A., 1985, Criteria for the recognition of salt-pan evaporites: Sedimentology, v. 32, p. 627-644, doi:10.1111/j.1365-3091.1985.tb00478.x.

Matheson, E.J., and Frank, T.D., 2020, Phosphorites, glass ramps and carbonate factories: the evolution of an epicontinental sea and a late Palaeozoic upwelling system (Phoiphoria Rock Complex): Sedimentology, p. sed.12731, doi:10.1111/sed.12731.

Matter, A., and Tucker, M.E., eds., 2009, Modern and ancient lake sediments (Alberttter \& urice E. Tucker, Eds.): Blackwell Publishing Ltd., 1-290 p., doi:10.1002/9781444303698.

Maughan, E.K., 1966, Environment of deposition of Permian salt in the Williston and Alliance basins: second symposium on salt, The Northern Ohio Geological Society Cleveland, v. 1, p. $35-47$.

Maughan, E.K., 1993, Phosphoria Formation (Permian) in the Western Interior, U.S.A: Canadian Society of Petroleum Geologists; Calgary; AB, 201 p.

Maughan, E., 1964, US Geological Survey Professional Paper 50: The Goose Egg Formation in the Laramie Range and adjacent parts of southeastern Wyoming: US Geological Survey Professional Paper, B53-B60

Mudge, B.F., 1872, Red sandstone of central Kansas: Transactions of the Kansas Academy of Science (1872-1880), v. 1, p. 37-39, doi:10.2307/3623513.

Muller, R., Nystuen, J.P., and Wright, V.P., 2004, Pedogenic mud aggregates and paleosol development in ancient dryland river systems: criteria for interpreting alluvial mudrock 
origin and floodplain dynamics: Journal of Sedimentary Research, v. 74, p. 537-551, doi:10.1306/010704740537.

Murad, E., and Fischer, W.R., 1988, The geobiochemical cycle of iron, in Stucki, J. W., Goodman, B. A., \& Schwertmann, U. eds., Iron in Soils and Clay Minerals, Springer Netherlands, p. 1-18, doi:10.1007/978-94-009-4007-9_1.

Murchison, R.I., 1841, First sketch of some of the principal results of a second geological survey of Russia: Philosophical Magazine Series 3, v. 19, p. 417-422, doi:10.1080/14786444108650460.

North, C.P., and Davidson, S.K., 2012, Unconfined alluvial flow processes: Recognition and interpretation of their deposits, and the significance for palaeogeographic reconstruction: Earth-Science Reviews, v. 111, p. 199-223, doi:10.1016/j.earscirev.2011.11.008.

Olariu, C., Bhattacharya, J.P., Leybourne, M.I., Boss, S.K., and Stern, R.K., 2012, Interplay between river discharge and topography of the basin floor in a hyperpycnal lacustrine delta: Sedimentology, v. 59, p. 704-728, doi:10.1111/j.1365-3091.2011.01272.x.

Opdyke, N.D., and Runcorn, S.K., 1960, Wind direction in the western United States in the late Paleozoic: Geological Society of America Bulletin, v. 71, p. 959-972, doi:10.1130/0016-76 06(1960)71[959:WDITWU]2.0.CO;2.

Parker, J.M., 1967, Salt solution and subsidence structures, Wyoming, North Dakota, and Montana: AAPG Bulletin, v. 51, p. 1929-1947, doi:10.1306/5d25c1eb-16c1-11d7$8645000102 \mathrm{c} 1865 \mathrm{~d}$.

Paull, R. a., and Paull, R.K., 1990, Persistent myth about the Lower Triassic Little Medicine Member of the Goose Egg Formation and the Lower Triassic Dinwoody Formation, Central Wyoming: , p. 57-68.

Peterson, J.A., 1984, Permian stratigraphy, sedimentary facies, and petroleum geology, Wyoming and adjacent area in Goolsby, J., Morton, eds., The Permian and Pennsylvanian geology of Wyoming: 35th Annual Field Conference Guidebook, p. 25-64.

Platt, N.H., 1989, Lacustrine carbonates and pedogenesis: sedimentology and origin of palustrine deposits from the Early Cretaceous Rupelo Formation, W Cameros Basin, N Spain, Sedimentology, v. 36, p. 323-342, doi:10.1111/j.1365-3091.1989.tb02092.x.

Platt, N.H., and Wright, V.P., 1991, Lacustrine carbonates: facies models, facies distributions and hydrocarbon aspects, in Anadón, P., Cabrera, L., and Kelts, K. eds., Lacustrine facies analysis, Blackwell Publishing Ltd., p. 57-74, doi:10.1002/9781444303919.ch3. 
Pollastro, R.M., Schenk, C.J., Coury, A.B., and Dyman, T.S., 1991, Origin and diagenesis of clay minerals in relation to sandstone paragenesis; an example in eolian dune reservoirs and associated rocks, Permian upper part of the Minnelusa Formation, Powder River basin, Wyoming: Open-File Report - U. S. Geological Survey, p. 23.

Posamentier, H.W., 2009, Sequence stratigraphy and facies associations: Special Publication 18 of the IAS: John Wiley \& Sons, 600 p.

Rasmussen, D.L., and Bean, D.W., 1983, Dissolution of Permian salt and Mesozoic depositional trends, Powder River basin, Wyoming: AAPG Bulletin, v. 67, p. 281-294, doi:http://dx.doi. org.www.libproxy.wvu.edu/10.1306/03B5B961-16D1-11D7-8645000102C1865D.

Retallack, G.J., 1998, Core concepts of paleopedology: Quaternary International, v. 51-52, p. 203-212, doi:10.1016/S1040-6182(97)00046-3.

Retallack, G.J., 2008, Soils of the past: an introduction to paleopedology: John Wiley \& Sons, 419 p.

Riding, R., 2000, Microbial carbonates: the geological record of calcified bacterial-algal mats and biofilms: Sedimentology, v. 47, p. 179-214, doi:10.1046/j.1365-3091.2000.00003.x.

Rogers, J., 1958, The significance of grain size distributions in clastic sedimentary rocks: Gulf Coast Association of Geological Societies Transactions, v. 8.

Rodgers, J., 1954, Nature, usage, and nomenclature of stratigraphic units: a minority report: Stratigraphic Commission: AAPG Bulletin, v. 38, p. 655-659, doi:10.1306/5ceadf02-16bb$11 \mathrm{~d} 7-8645000102 \mathrm{c} 1865 \mathrm{~d}$.

Rosen, M.R., 1991, Sedimentologic and geochemical constraints on the evolution of Bristol Dry Lake Basin, California, U.S.A: Palaeogeography, Palaeoclimatology, Palaeoecology, v. 84, p. 229-257, doi:10.1016/0031-0182(91)90046-T.

Rust, B.R., and Nanson, G.C., 1989, Bedload transport of mud as pedogenic aggregates in modern and ancient rivers: Sedimentology, v. 36, p. 291-306, doi:10.1111/j.1365-3091.1989. tb00608.x.

Saltzman, M.R., and Sedlacek, A.R.C., 2013, Chemostratigraphy indicates a relatively complete Late Permian to Early Triassic sequence in the western United States: Geology, v. 41, p. 399-402, doi:10.1130/G33906.1.

Schenk, C.J., Schmoker, J.W., and Fox, J.E., 1993, Sedimentology of Permian upper part of the Minnelusa Formation, eastern Powder River basin, Wyoming, and a comparison of the sub- 
surface: The Mountain Geologist, v. 30, p. 71-80.

Schenk, C.J., Schmoker, J.W., Scheffler, J.M., 1986, Characterizing Permian upper Minnelusa sandstone reservoirs, Powder River basin, Wyoming, for enhanced oil recovery: AAPG Bulletin, v. 70, p. 1054.

Schindler, M., and Hochella, M.F., 2015, Soil memory in mineral surface coatings: environmental processes recorded at the nanoscale: Geology, v. 43, p. 415-418, doi:10.1130/G36577.1.

Schreiber, B.C., 1988, Evaporites and hydrocarbons: Columbia Univ Pr.

Schwertmann, U., 1988, Occurrence and formation of iron oxides in various pedoenvironments: in Stucki, J. W., Goodman, B. A., \& Schwertmann, U. eds., iron in soils and clay minerals, Springer Netherlands, p. 37-62, doi:10.1007/978-94-009-4007-9_3.

Schwertmann, U., and Taylor, R.M., 2018, Iron oxides, in John Wiley \& Sons, Ltd, p. 379-438, doi:10.2136/sssabookser1.2ed.c8.

Sephton, M.A., Jiao, D., Engel, M.H., Looy, C. V., and Visscher, H., 2015, Terrestrial acidification during the end-Permian biosphere crisis? Geology, v. 43, p. 159-162, doi:10.1130/ G36227.1.

Shanley, K.W., and McCabe, P.J., 1994, Perspectives on the sequence stratigraphy of continental strata: American Association of Petroleum Geologists Bulletin, v. 78, p. 544-568, doi:10.1306/bdff9258-1718-11d7-8645000102c1865d.

Sheldon, R.P., 1955, Stratigraphy of the Phosphoria Formation in the Wyoming and Wind River Ranges: Wyoming Geological Association Guidebook, v. 10th Annua, p. 64.

Smalley, I. J. 1966, The properties of glacial loess and the formation of loess deposits: SEPM Journal of Sedimentary Research, v. Vol. 36, p. 669-676, doi:10.1306/74d7153c-2b2111d7-8648000102c1865d.

Smoot, J.P., and Castens-Seidell, B., 1994, Sedimentary features produced by efflorescent salt crusts, Saline Valley and Death Valley, California: Sedimentology and geochemistry of modern and ancient saline lakes, p. 73-90, doi:10.2110/pec.94.50.0073.

Smoot, J.P., and Lowenstein, T.K., 1991, Depositional environments of non-marine evaporites: Developments in Sedimentology, v. 50, p. 189-347, doi:10.1016/S0070-4571(08)70261-9.

Soreghan, G.S., Benison, K.C., Foster, T.M., Zambito, J., and Soreghan, M.J., 2015, The paleoclimatic and geochronologic utility of coring red beds and evaporites: a case study from the RKB core (Permian, Kansas, USA): International Journal of Earth Sciences, v. 104, p. 
1589-1603, doi:10.1007/s00531-014-1070-1.

Soreghan, G.S., Soreghan, M.J., and Hamilton, M.A., 2008a, Origin and significance of loess in late Paleozoic western Pangaea: A record of tropical cold? Palaeogeography, Palaeoclimatology, Palaeoecology, v. 268, p. 234-259, doi:10.1016/j.palaeo.2008.03.050.

Soreghan, G.S., Soreghan, M.J., Poulsen, C.J., Young, R.A., Eble, C.F., Sweet, D.E., and Davogustto, O.C., 2008b, Anomalous cold in the Pangaean tropics: Geology, v. 36, p. 659-662, doi:10.1130/G24822A.1.

Stoffregen, R.E., Alpers, C.N., and Jambor, J.L., 2019, Alunite-jarosite crystallography, thermodynamics, and geochronology, in Sulfate Minerals: Crystallography, Geochemistry, and Environmental Significance, Walter de Gruyter GmbH, v. 40, p. 453-479, doi:10.2138/ rmg.2000.40.9.

Sun, J., 2002, Provenance of loess material and formation of loess deposits on the Chinese Loess Plateau: Earth and Planetary Science Letters, v. 203, p. 845-859, doi:10.1016/S0012$821 \mathrm{X}(02) 00921-4$.

Sweet, A.C., Soreghan, G.S., Sweet, D.E., Soreghan, M.J., and Madden, A.S., 2013, Permian dust in Oklahoma: source and origin for Middle Permian (Flowerpot-Blaine) redbeds in Western Tropical Pangaea: Sedimentary Geology, v. 284-285, p. 181-196, doi:10.1016/j. sedgeo.2012.12.006.

Tabor, N.J., 2013, Wastelands of tropical Pangea: high heat in the Permian: Geology, v. 41, p. 623-624, doi:10.1130/focus052013.1.

Thomas, H.D., 1934, Phosphoria and Dinwoody Tongues in Lower Chugwater of Central and Southeastern Wyoming: AAPG Bulletin, v. 18, p. 1655-1697, doi:10.1306/3d932c9a-16b1$11 \mathrm{~d} 7-8645000102 \mathrm{c} 1865 \mathrm{~d}$.

Thomas, H.D., 1948, Summary of Paleozoic stratigraphy of the Wind River basin, Wyoming, in Wyoming Geological Association, Field Conference Guidebook, p. 79-95.

Tomlinson, C.W., 1916, The Origin of Red Beds: A study of the conditions of origin of the Permo-Carboniferous and Triassic red beds of the western United States: The Journal of Geology, v. 24, p. 238-253, doi:10.2307/30078150.

Tsoar, H., and Pye, K., 1987, Dust transport and the question of desert loess formation: Sedimentology, v. 34, p. 139-153, doi:10.1111/j.1365-3091.1987.tb00566.x.

Van, E., and De, F., 2002, Evaluation of ferrolysis in soil formation: European Journal of Soil 
Science, v. 53, p. 513-520, doi:10.1046/j.1365-2389.2002.00475.x.

Walker, T.R., 1967a, Color of recent sediments in tropical Mexico: a contribution to the origin of red beds: Geological Society of America Bulletin, v. 78, p. 917-920, doi:10.1130/0016-7606(1967)78[917:CORSIT]2.0.CO;2.

Walker, T.R., 1967b, Formation of red beds in modern and ancient deserts: Geological Society of America Bulletin, v. 78, p. 353-368, doi:10.1130/0016-7606(1967)78[353:FORBIM]2.0. $\mathrm{CO} ; 2$.

Walker, T.R., 1974, Formation of red beds in moist tropical climates: a hypothesis: Geological Society of America Bulletin, v. 85, p. 633-638, doi:10.1130/0016-7606(1974)85<633:FOR$\mathrm{BIM}>2.0 . \mathrm{CO} ; 2$.

Wang, H.D., White, G.N., Turner, F.T., and Dixon, J.B., 1993, Ferrihydrite, Lepidocrocite, and Goethite in coatings from East Texas vertic soils: Soil Science Society of America Journal, v. 57, p. 1381-1386, doi:10.2136/sssaj1993.03615995005700050036x.

Washington, R. et al., 2006, Links between topography, wind, deflation, lakes and dust: the case of the Bodélé Depression, Chad: Geophysical Research Letters, v. 33, p. L09401, doi:10.1029/2006GL025827.

Wignall, P.B., 2001, Large igneous provinces and mass extinctions: Earth-Science Reviews, v. 53, p. 1-33, doi:10.1016/S0012-8252(00)00037-4.

Wright, J.S., 2001, "Desert" loess versus "glacial" loess: quartz silt formation, source areas and sediment pathways in the formation of loess deposits: Geomorphology, v. 36, p. 231-256.

Wright, V.P., 1994, Paleosols in shallow marine carbonate sequences: Earth Science Reviews, v. 35, p. 367-395, doi:10.1016/0012-8252(94)90002-7.

Zambito, J.J., and Benison, K.C., 2013, Extremely high temperatures and paleoclimate trends recorded in Permian ephemeral lake halite: Geology, v. 41, p. 587-590, doi:10.1130/ G34078.1.

Zavala, C., Arcuri, M., Meglio, M. Di, Diaz, H.G., and Contreras, C., 2011, A genetic facies tract for the analysis of sustained hyperpycnal flow deposits: , p. 31-52, doi:10.1306/13271349St613438. 


\section{CHAPTER 3}

Title: The Permian-Triassic red beds of the Red Peak Formation, Wyoming (USA) Part I: Ephemeral lake deposits, loess, and alluvium modified by pedogenesis

Authors:

JONATHAN P. KNAPP ${ }^{1,2}$, KATHLEEN C. BENISON ${ }^{1}$

${ }^{1}$ Department of Geology and Geography, West Virginia University, Morgantown, West Virginia, U.S.A. 26506-6300

${ }^{2}$ Bruker Nano Analytics, Berlin, 12489, Germany;

Corresponding Author: Jonathan Knapp, Jonathan.Knapp@bruker.com

keywords: Red Peak, Chugwater, Triassic, lacustrine, red beds, automated mineralogy, paleosols 


\begin{abstract}
The Red Peak Formation of the Triassic Chugwater Group (Wyoming, USA) is a thick sequence of fine-grained red beds. This formation has been previously interpreted as a marine or marginal marine deposit, based on gypsum and laterally extensive beds. However, neither gypsum nor laterally extensive beds are diagnostic criteria for marine or marginal marine deposition. Could the Red Peak Formation have formed in continental environments? A detailed sedimentological study of the Red Peak Formation throughout Wyoming was undertaken to resolve this conflict. Detailed measured sections, petrographic observations, and geochemical analyses were conducted to determine if the Red Peak Formation was deposited in marine or non-marine environments of deposition.
\end{abstract}

The results of this study suggest that the Red Peak Formation was deposited in a fully continental environment. Sediment was deposited from the weakly confined distributive fluvial system, unconfined overland flow, and eolian processes. Ephemeral saline lakes and mudflats existed. Extensive pedogenic overprinting resulted in well developed soils. The Red Peak Formation environments are consistent with Pangea's recent geographic interpretations in the late Permian and Early Triassic. At this time, Pangea was likely dominated by internally drained basins with extreme environmental conditions on distal alluvial fans from the Equator to mid-latitudes. The Red Peak Formation may be representative of a Pangea-wide environmental perturbation during Permian-Triassic times that resulted in a "globally weird" environment and geochemistry. 


\section{INTRODUCTION}

The Permian and Triassic were times of great upheaval in Earth's history. The Late Paleozoic icehouse climate reached a zenith during the Early Permian and began a long trend towards warming and acidification (Isbell et al., 2003; Montañez and Poulsen, 2013; Limarino et al., 2014) with widespread aridity by the middle of the Permian (Parrish, 1993; Tabor and Poulsen, 2008). Consequences of this aridity in midcontinent Pangea have included: (1) periodic mass extinctions of vertebrates, such as the major reduction in the diversity of therapsids called "Olson's gap" at the end of the Early Permian (Lucas, 2017); (2) disappearance of paleosols with abundant roots and clear horizons such as alfisols and replacement with soils with weakly developed horizonation and pedogenic gypsum and carbonate (Tabor and Montañez, 2002; Retallack et al., 2003, 2011) by the middle Permian; (3) accumulation of thick, fine-grained, wind-derived red-bed sediments (Kessler et al., 2001; Soreghan et al., 2008a); and (4) development of a large system of acid saline lakes and groundwaters, starting in the middle Permian and extending into the Triassic (Andeskie et al., 2018; Benson et al., 1998; Benison and Goldstein, 2000, 2001). In addition to extreme aridity, there is evidence of extremely high air temperatures during the middle Permian and extreme increases in atmospheric $\mathrm{pCO}_{2}$ (Tabor, 2007; Payne and Kump, 2007; Zambito and Benison, 2013). The Permian-Triassic transition marks the largest mass extinction in Earth history. Reconstructions of deep-time climate, ecology, and geography through this time of global upheaval are dependent on interpretations of depositional environments.

Red beds are the most distinctive stratigraphic units in the Permian-Triassic rock record in western Pangea. Early studies considered the thick Permian and Triassic red sediment to be a single succession of rock stretching north to south from Montana to Texas and east to west from Kansas to Arizona (Tomlinson, 1916). However, correlation attempts have been complicated by a paucity of fossils and deformation by later tectonics. Furthermore, environmental reconstructions and correlations are challenging in outcrops, which may not be complete due to late-stage dissolution of evaporites, including halite cement, bedded halite, and displacive halite (Benison et al., 2015). For example, salt dissolution has resulted in up to $80 \%$ thickness loss of the upper Goose Egg Formation and lower Red Peak Formation (Rasmussen and Bean, 1984). Despite these difficulties, interpreting depositional environments from Permian-Triassic red beds is critical for understanding Earth ecosystems during and after $\mathrm{a} \mathrm{CO}_{2}$-driven ecological disruption, contextualized within a long-term trend of increasing aridity and global warming (Kutzbach and Gallimore, 1989; Parrish, 1993; Tabor and Montañez, 2002; Tabor, 2013 and references therein). 
The Red Peak Formation, the Triassic Chugwater Group's basal unit, is one of the most northern of the many Permian-Triassic red bed units in North America. The Red Peak Formation has traditionally been considered marine or marginal marine (Picard, 1965). A marine assignment was made mainly based on the laterally extensive nature of bedding, gypsum beds, and alternating silt and mud sized sediments (Picard and High, 1963). This marine/marginal marine interpretation contrasts with those of other thick red bed successions of Pangea, where recent work has described a landscape of acid saline lake systems and thick eolian dust accumulations (Benison and Goldstein, 2001; Soreghan et al., 2008a). Recently described ichnoassemblages from the Red Peak Formation have been interpreted as continental (Lovelace and Lovelace, 2012). A detailed sedimentological examination of the Red Peak Formation is needed to reconcile it in the context of other Permo-Triassic rocks in western Pangea. Additionally, this study seeks to document the laterally extensive bedding of fine-grained units within the Red Peak Formation. Resolving the Red Peak Formation enigma will enable a fuller understanding of environmental response to global climatic extremes.

\section{GEOLOGIC BACKGROUND}

\section{Stratigraphy and Sedimentology of the Red Peak Formation}

The thick successions of red beds have intrigued and baffled geologists since the first geologic expeditions to the American west (Hayden, 1872). The Chugwater Formation, consisting of conspicuous red rocks near Fort Laramie and Casper, Wyoming (Fig. 1), was originally named by Darton (1904) with the Red Peak Member named by Love (1939). Later, the Chugwater was reassigned as a group and the Red Peak as a formation (Branson, 1947). The first speculation on the Chugwater deposition environment was "a widespread lake of saline water" (Darton, 1906). Tomlinson (1916), the first to attribute red pigmentation in western rocks to soils, wrote: "all of the other common chemical constituents of rock, with the probable exception of alumina, are leached from the soil more rapidly than ferric iron." A contemporary of Darton and Tomlinson, Branson (1915) strongly disagreed with them, insisting that the presence of thin gypsum units over such a large area must be marine in origin. Later works largely agreed on a marine depositional environment, based on laterally extensive beds and gypsum (Branson, 1927; Thomas, 1934). Burke (1953) rather inextricably concluded from electric logs alone that the Red Peak was deposited from "widespread distribution of similar sediments through the effects of the sea in spreading these finer clastics over a broad littoral or sub-littoral plain after deposition on this plain by sluggish streams and rivers." Picard (1966) interpreted an arid climate during deposition of the Red Peak Formation and source areas to the north and northwest and increased salinity to the north and west based on mineralogy trends, particularly dolomite cement, the relative amount 
of feldspars, and the presence of gypsum. Later, Picard (1966) divided the Red Peak into five lithological units: (1) silty claystone interpreted to be transitional from marine to non-marine based on bed morphology; (2) a lower platy facies interpreted to be tidal deposits based on the presence of gypsum, abundant current ripple marks, and unusual channel geometries; (3) a laterally extensive facies consisting of beds of alternating grain sizes and interpreted as alternating shallow-water and deeper water marine deposits (also, Picard and Hugh,1963); (4) an upper platy unit with gypsum and unusual gypsum interpreted to be a tidal flat deposit.; and (5) a laterally extensive sandy unit interpreted to be a near-shore shallow marine deposit. Later, workers largely agreed on the overall framework of a marine or marginal marine environment with the sabkha terminology and some tentative deltaic or fluvial deposits (Cavaroc and Flores, 1991; Johnson, 1993).

Although Picard's marine/marginal marine interpretation (Picard, 1966) has persisted for the Red Peak Formation, suggestions of a terrestrial origin have slowly emerged. Boyde and Loope

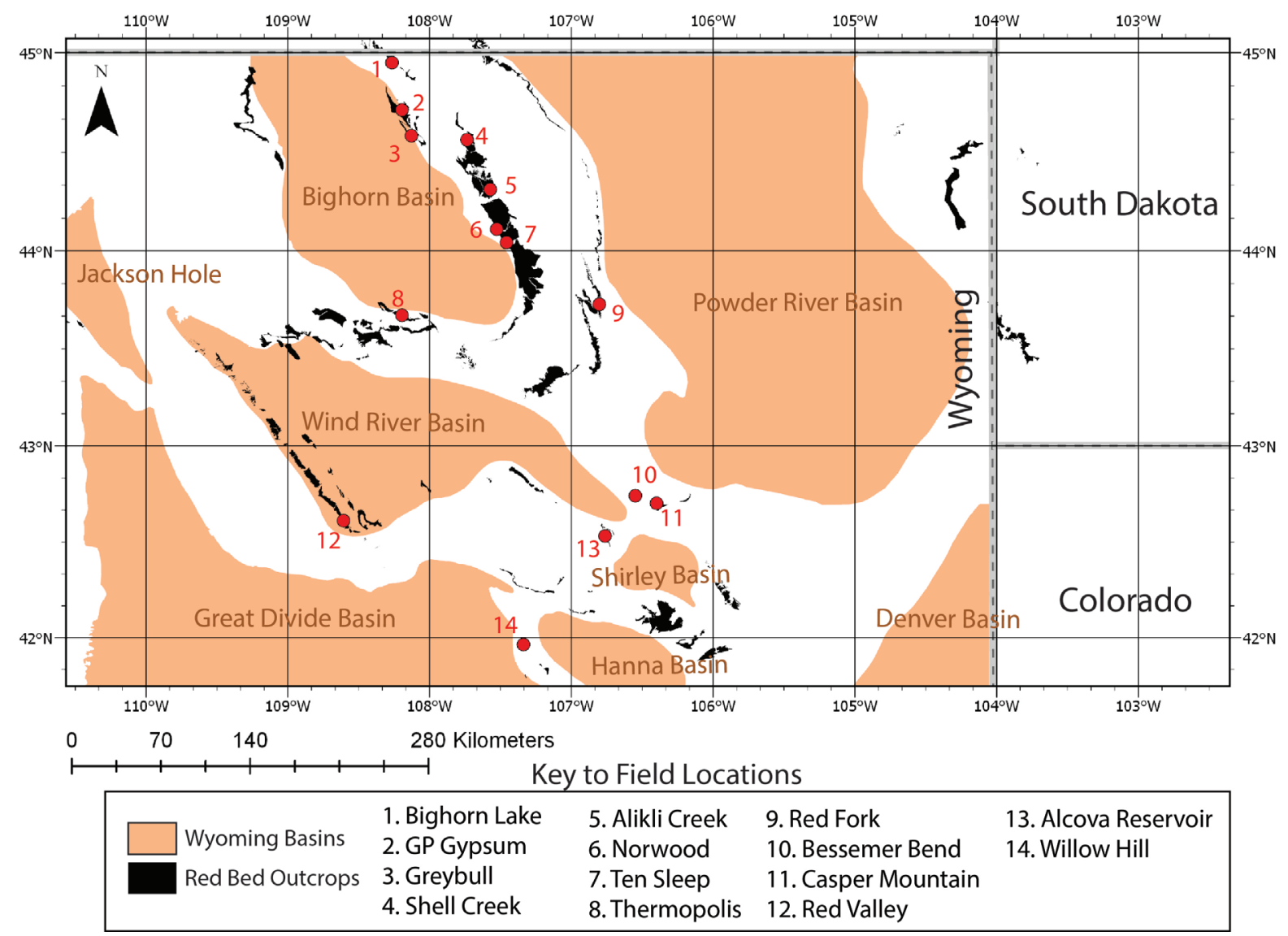

Fig. 1: Location of major field sites. The Red Peak Formation is exposed along the edges of Laramide uplifts through central Wyoming and into South Dakota and Montana. 
(1984) suggested that sole mark-like patterns were made by amphibious tetrapods moving against river currents. They considered the presence of the same trace fossils across geologic units "puzzling." Irmen and Vondra (2000) identified isolated eolian beds in the Red Peak Formation. Lovelace and Lovelace (2012) described a diverse ichnofauna made by vertebrates and invertebrates and indicative of floodplain deposits in the upper platy facies of Picard (1966). However, despite decades of geological interest in the Red Peak Formation, no comprehensive descriptions of its sedimentology have yet been made.

\section{Age of the Red Peak Formation}

The age of the Red Peak Formation is uncertain. It has no identifiable body fossils and no identified volcanic ash that can be dated, so age estimates rely on relative dating. The Red Peak Formation is underlain by the Dinwoody Formation in western Wyoming's Bighorn and Wind River Basins and by the Goose Egg Formation in eastern and central Wyoming in the Powder River Basin (Fig. 2). The Goose Egg at Casper Mountain (Fig. 3E, no. 1) resembles the rocks that underlie the Red Peak at Shell Creek on the edge of the Bighorn Basin (Fig. 3A). A clear instance of the contact between the Dinwoody and Red Peak Formations were not found; nevertheless, the Dinwoody has been considered the primary lower age constraint for the Red Peak Formation (Picard et al., 1969). Conodonts in the Dinwoody Formation, where it underlies the Thaynes Limestone in the Wind River Mountains of Wyoming and is traced into the Bighorn Basin, as well as southeastern Montana and Idaho, have been attributed to Griesbachian age (earliest Triassic; 251.9 -251.2 Ma), (Boyd and Maughan, 1972; Paull et al., 1991; Paull and Paull, 1992, 1993, 1994). The age of the Dinwoody Formation underlies the Red Peak Formation is more ambiguous, leading to the Red Peak Formation being assigned to either the Permian or the Triassic (Paull and Paull, 1993). The Goose Egg Formation, underlying the Red Peak Formation at Casper Mountain, Bessemer Bend, and Alcova, has been attributed to the late Permian by long-distance correlation (Maughan, 1964). The Red Peak Formation's upper age limit is constrained by the overlying Alcova Limestone, for which rare vertebrate body fossils and ichnoassablages were used to assign a Middle Triassic age (Storrs, 1991; Lovelace and Doebbert, 2015). Thus, the Red Peak Formation is most likely Early Triassic, perhaps spanning the Permian-Triassic boundary in its central geographic range. The interrelationships between the Dinwoody and various subdivisions of the Goose Egg and Red Peak Formations have been predicated on a presupposition of extensive correlation of strata, despite disagreements about correlations even when "walking out beds" in the same mountain range (Thomas, 1934). Stratigraphic relationships of many rocks in the Permian-Triassic deserve a detailed reexamination beyond the scope of this study. 


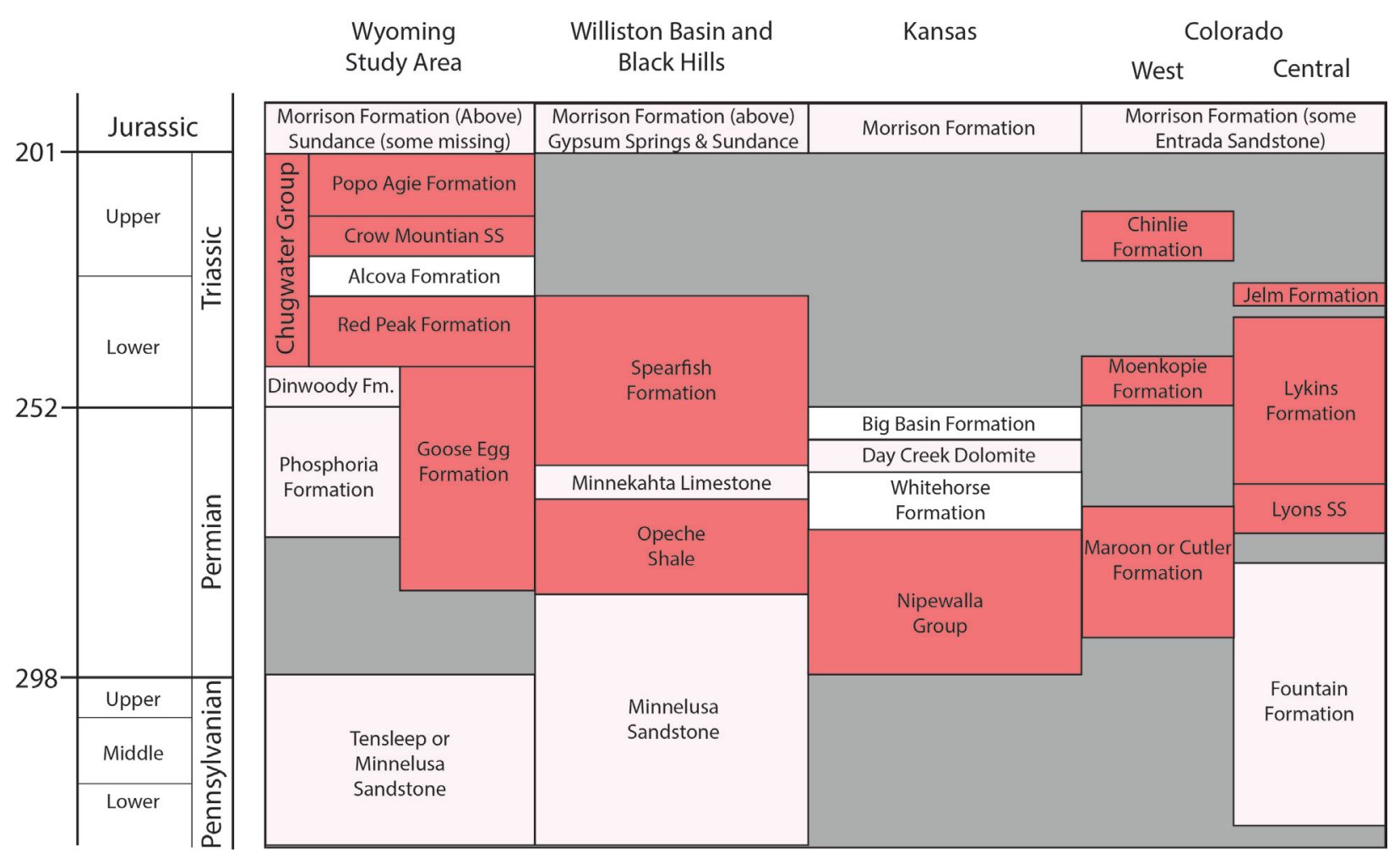

Fig. 2: Simplified stratigraphic nomenclature and correlations of major Permian and Triassic units in Wyoming and the midcontinent. Red units indicate a thick succession of fine-grained red beds like the Red Peak Formation. Correlations of the Red Peak Formation to other units and age constraints for the Red Peak Formation is tenuous.

\section{MATERIALS AND METHODS}

\section{Study Site}

This study consisted of fieldwork, petrography, and geochemical analyses of the Red Peak Formation of the Chugwater Group in Wyoming, USA. The Red Peak Formation is exposed o Larmide uplifts' flanks (Fig. 1), where the red bed is a cliff-forming unit below the Alcova Limestone caprock (Fig. 3). This study focused on thirteen localities, where the Red Peak Formation is both well exposed and accessible. Those locations in Wyoming are: (1) Bighorn Lake near the Montana border, (2) The Georgia Pacific Gypsum mine (GP Gypsum) south of Kane, (3) the cliffs above the Bighorn River in Greybull, (4) the entrance to Shell Canyon above Shell Creek, (5) the cliffs above Alkali Creek north of the Medicine Lodge State Archeological Site, (6) along Norwood Road between Ten Sleep and Hyattville, (7) the cliffs above the Norwood River in Ten Sleep, (8) partial exposures both south and north of Thermopolis, (9) along the Red Fork of the Powder River near Elk Mountian (Red Fork), (10) Bessemer Bend, southwest of Casper, (11) Casper Mountain southeast of Casper, (12) the Red Valley near Lander, (13) the Alcova Reservoir and Dam, and (13) Willow Hill, north of Rawlins (Fig. 1). 

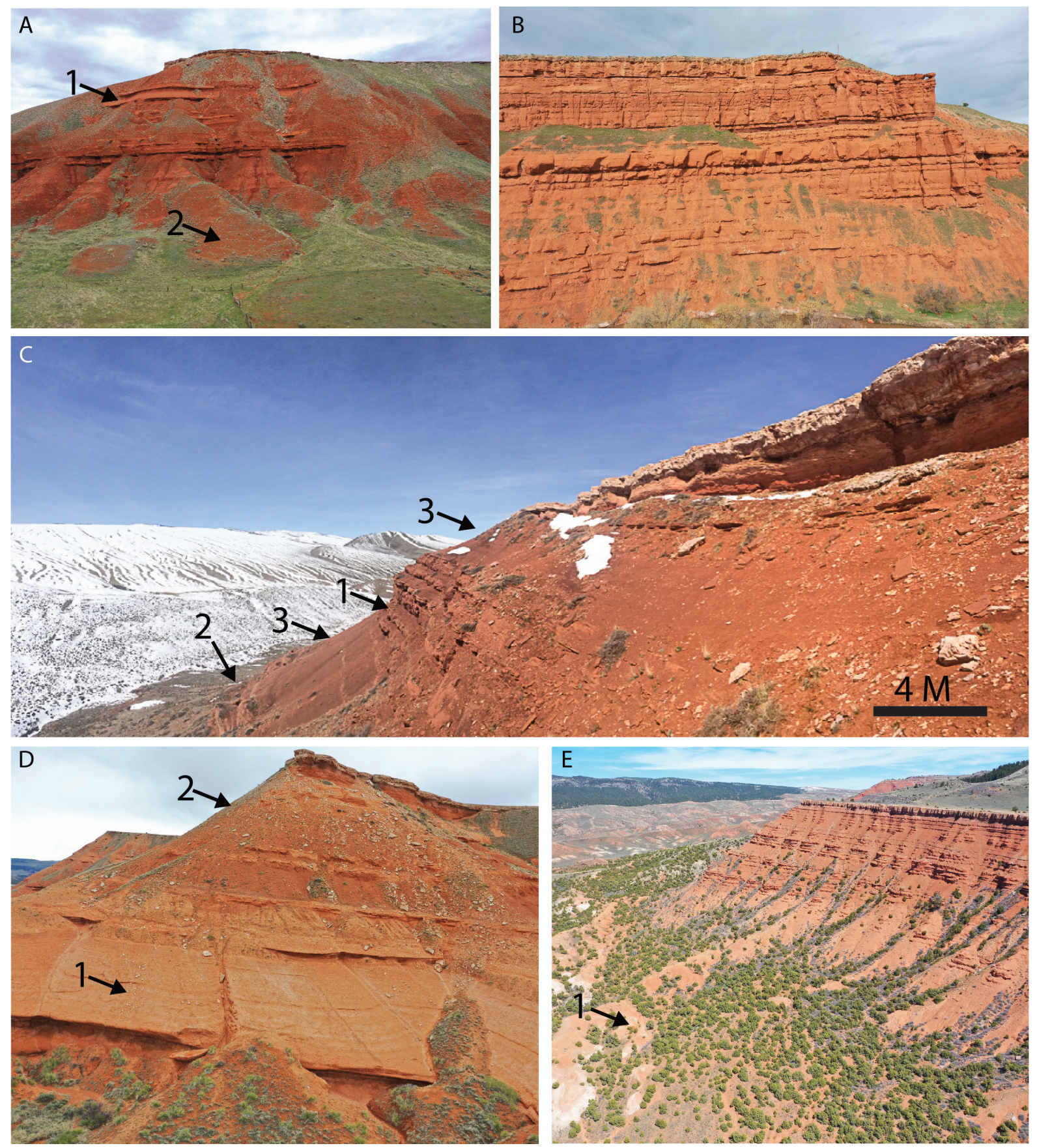

Fig. 3: Cliff-forming outcrops of the Red Peak Formation in Wyoming. Most outcrops of the Red Peak Formation are steep and hard to access. (A) At Shell Creek, The Red Peak Formation (Point 1) and Goose Egg Formation (point 2) is 89 vertical meters from the first exposure of the Goose Egg Formation to the exposure of the Alcova Limestone at the top. (B) At Ten Sleep, the Red Peak is 90 vertical meters from the Norwood river to the Alcova Limestone. $(C)$ A detail of the Red Valley demonstrates the typical weathering profile of alternating lithofacies associations (no. 1), agglomerated resistant lithofacies association (no. 2), and stacked recessive lithofacies association (no. 3). (D) At Alkali Creek, a thick unit (no. 1) and stacked recessive unit (point 2). (E) At Casper Mountain, from the Goose Egg (no. 1) to the Alcova Limestone, it is more than 100 $m$ vertical height. 
Fieldwork was conducted in the summers of 2015, 2016, 2017, and the winter of 2019. Detailed, centimeter-scale sections (Fig. 4) were measured at two locations, Willow Hill and the Alcova Reservoir, where topography and road cuts facilitated access to the entire section. Detailed observations of partial sections of the Red Peak Formation were conducted at three more localities; Red Valley near Lander, Casper Mountain, and Thermopolis. Meter-scale sections made with high-resolution photography and range-finding were constructed from those locations, as well as from Bessemer Bend, where close access was impossible. Outcrops were mapped with high-resolution aerial photography. Images were collected using a DGI Mavic 2 autonomous quadcopter drone equipped with a Hasselblad L1D-20c camera with a 1" CMOS detector capable of 20-megapixel resolution GPS+GLONASS geospatial positioning with $0.5 \mathrm{~m}$ accuracy. Flight paths were pre-designed using drone Deploy software in a double overlapping grid pattern to ensure over $60 \%$ overlap between images. Georeferenced 2D maps and 3D models were created in AgiSoft Metashape Professional Edition, and the drone Deploy online system. Measurements were made in the 3D modeling software Blender.

Measured sections described at the centimeter scale were made by describing color, composition, sedimentary textures, sedimentary structures, fossils, diagenetic features, and stratigraphic relationships, including bedding contacts and lateral transitions. Rocks were tested in the field with $\mathrm{HCl}$ to check for reactions that would indicate carbonate minerals. Hand samples representatives of lithotypes were collected at each detailed section. Photography was used to document field observations using a Canon D80 DSLR camera. Measured sections described at the meter scale (Fig. 5) were created using the high-resolution 2D and 3D photogrammetry with profile elevations for outcrop and detailed observations where possible. Profile elevations for outcrops were collected using a TruePulse 200L Rangefinder with a typical accuracy distance to the target of $0.5 \mathrm{~m}$ inclination accuracy of $0.5^{\circ}$ relative and a range of $1750 \mathrm{~m}$. True heights of outcrops were collected from several locations for each outcrop and measured to at least three points within three metes at each location. Where possible, ground control points were used to increase measurement accuracy and tie directly to areal maps. True stratigraphic thicknesses were calculated for measured sections after strike and dip collected with a Brunton measured at accessible locations. Data was collected in the ArcGIS Collector application on a Microsoft Surface Pro 2 tablet. Measured sections were drafted in Adobe Illustrator CS. 


\section{Thin Section Petrography}

Petrographic observations were made with eight large-format ( 2 × 3 in) and nine small-format (1 $\mathrm{x} 2$ in) thin sections. Observations were made on an Olympus SZX12 stereomicroscope and an Olympus BXS1 petrographic microscope with 4X, 10X, and 40X objectives. The Olympus SZX12 is capable of 6.3 - 63 x magnification and equipped with transmitted, reflected, and polarized light sources. A digital camera with Spot 5 imaging software was used to document petrographic observations on the SZX12, while an Olympus cellSense Dimensions was used on the BXS1.

\section{X-Ray Diffraction}

Semi-qualitative x-ray diffraction was conducted on three powdered samples to confirm the general mineralogy of the Red Peak Formation. A PANalytical X'pert Pro Cu anode X-ray diffractometer housed in the Shared Research Facilities at West Virginia University was used. Bulk powder samples were measured for 60 seconds per degree between 10 and 90 degrees. Bulk analyses did not distinguish clay minerals quantitatively. This qualitative mineralogy was used as a starting point to build automated mineralogy lists.

\section{Scanning Electron Microscopy and Automated Mineralogy}

Qualitative and quantitative scanning electron microscopy was conducted on eight samples at the Advanced Minerals Characterization Laboratory at the Colorado School of Mines in 2018. Samples were selected from couplets of resistant and recessive beds from the Willow Hill locality. Samples were made into small-format thick-section mounts at the Colorado School of Mines Sample Preparation Laboratory and specially polished and coated for SEM analysis. Resistant units were made into grain mounts in epoxy resin.

Automated mineralogy is a mineral identification method using a combination of BSE and EDS in an SEM (Gu et al., 2014). Automated mineralogy was conducted on the entire thin section for all samples at a resolution of 200x to enable comparison between resistant and recessive beds. Additional maps were collected at higher resolutions of select areas to elucidate textures further. Quantitative mineral mapping was conducted on a Hitachi FlexSEM 1000 compact SEM equipped with a Bruker Q80 EDS and Advanced Mineral Identification and Classification System (AMICS). AMICS is a $3^{\text {rd }}$ generation automated mineralogy system capable of automating data collection from the SEM and EDS systems and generating 2D mineral maps and quanti- 
tative modal mineralogy from thin sections. Backscatter electron images at a working distance of $10 \mathrm{~mm}$ were collected and automatically segmented based on greyscale differences. A small particle filter of $5 \mu \mathrm{m}$ and a minimum segment size of $1 \mu \mathrm{m}$ was used on all maps. Segment grey level factor and segment area factors were adjusted between 80 and 90 based on the resolution to capture grains while keeping the number of EDS points reasonable. EDS spectra are collected in each segment and assigned to a mineral by comparison to a mineral phase database. Initial mineral lists from XRD results were refined manually, using AMIC's spectrum tree feature. Spectra were filtered to single-phase bins using energy filtering and assigned to a mineral phase. This process identified minerals not detected in the XRD analysis and accounted for mineral mixes resulting from EDS of overlapping grains less than $1 \mu \mathrm{m}$ or from solid-state mixtures. The resulting mineral maps and BSE images were stitched together in AMICS to form a sample mosaic and modal mineralogy calculated. Images of representative microstructures were captured from 4 thick sections from couplets of resistant and recessive beds at the Willow Hill locality. Minerals were identified in high-resolution images from semi-quantitative elemental concentrations collected using the Bruker Esprit 2.0 software.

\section{RESULTS}

\section{Lithofacies and Lithofacies Associations}

The Red Peak Formation is divided into five lithofacies and three lithofacies associations (Fig. 6). The lithofacies are: (1) resistant lithofacies, (2) ped-overprinted mudstones, (3) bedded gypsum, (4) laminated mudstones, and (5) siltstone and sandstone lenses. The resistant lithofacies (Fig. 7) are cohesive and laterally extensive units that preserve original depositional or immediate post-depositional sedimentary structures. The ped-overprinted mudstone lithofacies (Fig. 8) are friable and preserve pedogenic features overprinting or completely obscuring depositional sedimentary structures. Bedded gypsum (Fig. 9), laminated silty mudstones (Fig. 10), and siltstone and sandstone lens (Fig. 11) are rarer than either the resistant sandy siltstone lithofacies or the ped-overprinted silty mudstone lithofacies. The resistant and ped-overprinted silty mudstone lithofacies grade into one another in the alternating lithofacies association in laterally extensive couplets (Fig. 6A, B). Bedsets of superimposed resistant lithofacies are the agglomerated resistant lithofacies association (Fig. 6C). Bedsets comprised of stacked and overlapping ped-overprinted silty mudstone lithofacies, bedded gypsum, and units of laminated mudstone are the recessive lithofacies (Fig. 6D). 


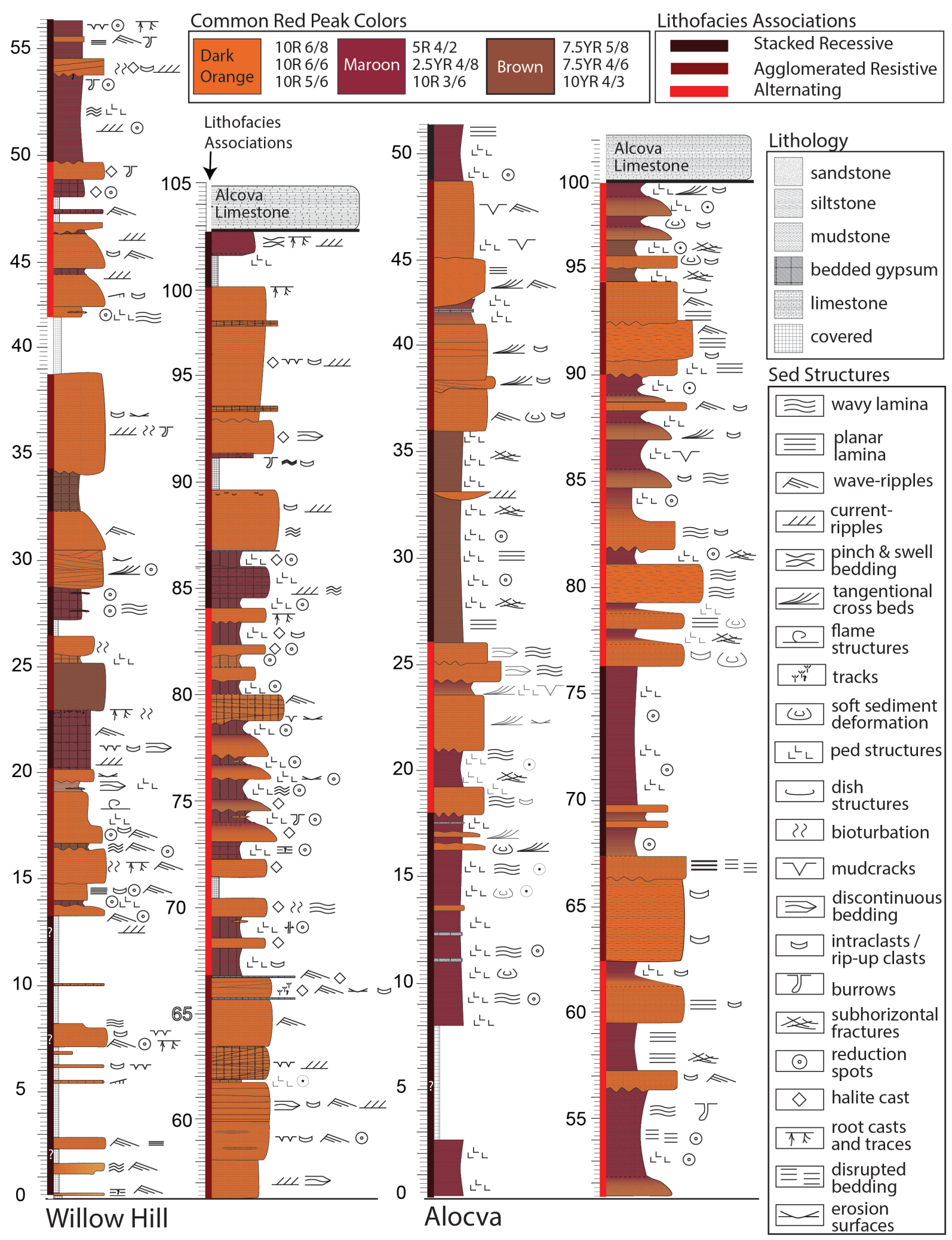

Fig. 4 - Detailed measured sections from Willow Hill and Alcova Reservoir with a centimeter-scale notation of sedimentary structures and features. 


\section{Resistant Lithofacies}

\section{Descriptions}

The resistant lithofacies is a light red (2.5YR 7/8) to light greyish red (5 YR 7/4) siltstone, sandy siltstone, or rare sandstone (Fig. 4-7). Sorting ranges from bimodal siltstone and fine sand (Fig. 16A) to rare sand-sized grains in siltstone (Fig. 16 C). Siltstone is well-sorted sub-rounded to sub-angular subspherical (0.7) grains of quartz, feldspar, orthoclase, and mica (Table 1). Sandsized grains are very-fine lower to fine sub-angular, moderately spherical $(0.5)$ to sub-spherical (0.7), and predominately quartz with minor amounts of feldspars and micas. Intraformational rip-up clasts of claystone and siltstone are common as sub-millimeter thick lags (Fig. 7G, no. 1). Intraformational rip-up range in size from very fine sand to pebbles ( 0.1 to $5 \mathrm{~mm}$ in diameter), with most being less than $0.5 \mathrm{~mm}$. Rip-ups have eroded edges, are often imbricated, and range from highly spherical to somewhat elongate (Fig. 18C). Rip-up clasts are common but are a minor constituent, never comprising more than $10 \%$ of the rock.

Beds of the resistant lithofacies range in thickness from $0.2 \mathrm{~m}$ to $2.5 \mathrm{~m}$ in bedsets up to $4 \mathrm{~m}$ thick. Individual beds can be traced for meters at single outcrops (Fig. 3) where they often indistinctly laterally merge with other beds within the bedset, are lost due to weathering of the outcrop face, tangentially onlap onto surfaces (Fig. 6C, No. 2), or are lost due to soft-sediment deformation (Fig. 6C, no. 1,3). Small-scale ( $>3 \mathrm{~m}$ tall) lateral or down-dip accretion of beds and internal erosional surfaces are common (Fig. 6C, no.5). Beds most commonly have erosional bases. Sedimentary structures (Fig. 7) include bioturbation, soft-sediment deformation, upper plane beds, ripple cross-laminae, small-scale cross-bedding, and ripple marks.

Bioturbation presents as highly mottled siltstone (Fig., 7A) with no taxonomically identifiable ichnofossils, circular to ovate filled burrows are 0.25 - $3 \mathrm{~mm}$ diameter clay-lined holes filled with coarser silt than the host rock. Filled burrows have an irregular surface and internal wavy circular structure and were present in all thin sections. Rare possible adhesive meniscus burrows were observed for thin section petrography (Fig. 16D, point 1). In a thin section (Fig. 9D, no. 1), burrows were exposed as tangential cuts but appear to be adhesive meniscus burrows that are 1 $2 \mathrm{~mm}$ in diameter, angled downward have clay lining and upward doming meniscus shapes.

Slightly disturbed bedding from minor soft-sediment deformation is common. Small-scale dish structures and slightly convolute laminations are common. More rarely, entire units have disturbed bedding (Fig. 6C, no. 1; Fig. 7A). Rare beds have been deformed to form fluid escape structures (Fig. 6C, no. 2) or have load structures up to $1 \mathrm{~m}$ across (Fig. 7B). 


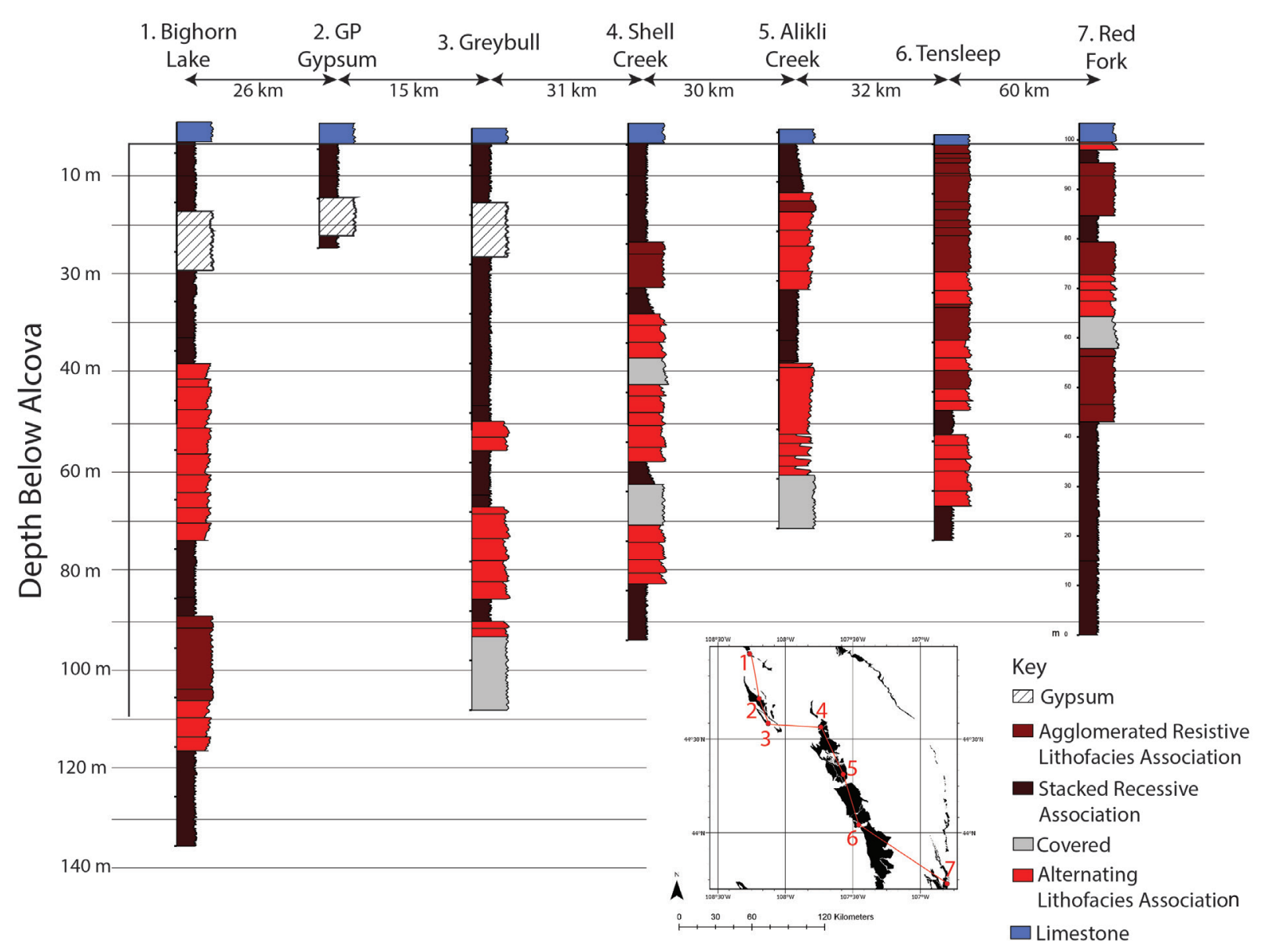

Fig. 5: Meter-scale measured sections in a transect from northwest to southeast along the Bighorn Mountains in Wyoming. Measurements were taken from 3D models generated from drones and laser rangefinders on outcrops too steep to access. The striatal stacking patterns of lithofacies assemblages are a complex mosaic of rarely traceable units from location to location, suggesting the scales of most facies elements are larger than a few kilometers but less than the outcrop to outcrop scale of the transect. However, the exception is the gypsum and mudstone unit exposed across $40 \mathrm{~km}$ from Bighorn Lake to GP Gypsum and Greybull.

Common upper plane beds (Fig. 7C, G) have erosive bases and are between $30 \mathrm{~cm}$ and 120 $\mathrm{cm}$ thick, forming above tabular or trough cross-bedding. Planer tabular cross-bedding occurs with sets from $1 \mathrm{~cm}$ thick to $20 \mathrm{~cm}$ thick with unidirectional tangential foresets that form trough co-sets up to $10 \mathrm{~cm}$ thick (Fig. 7G-I). Common cross-bedding sets also occur with tangential unidirectional foresets between $1 \mathrm{~cm}$ and $15 \mathrm{~cm}$ in both trough and wedge co-sets (Fig. $7 \mathrm{D}-\mathrm{F}$ ). Commonly, the erosional surfaces that shallowly cut into predecessor units $(>20 \mathrm{~cm})$ are overlain by one or two $3 \mathrm{~cm}$ to $5 \mathrm{~cm}$ thick bed of fine sand or silt with an undulatory top; bedforms that appear to be back-flow ripples. Single sets of tabular cross-bedding up to $30 \mathrm{~cm}$ thick with tangential foresets that onlap onto erosional surfaces at the base of units are common (Fig. 7I, 8G, no. 2). Bedding plane surfaces often have asymmetric ripple marks. 

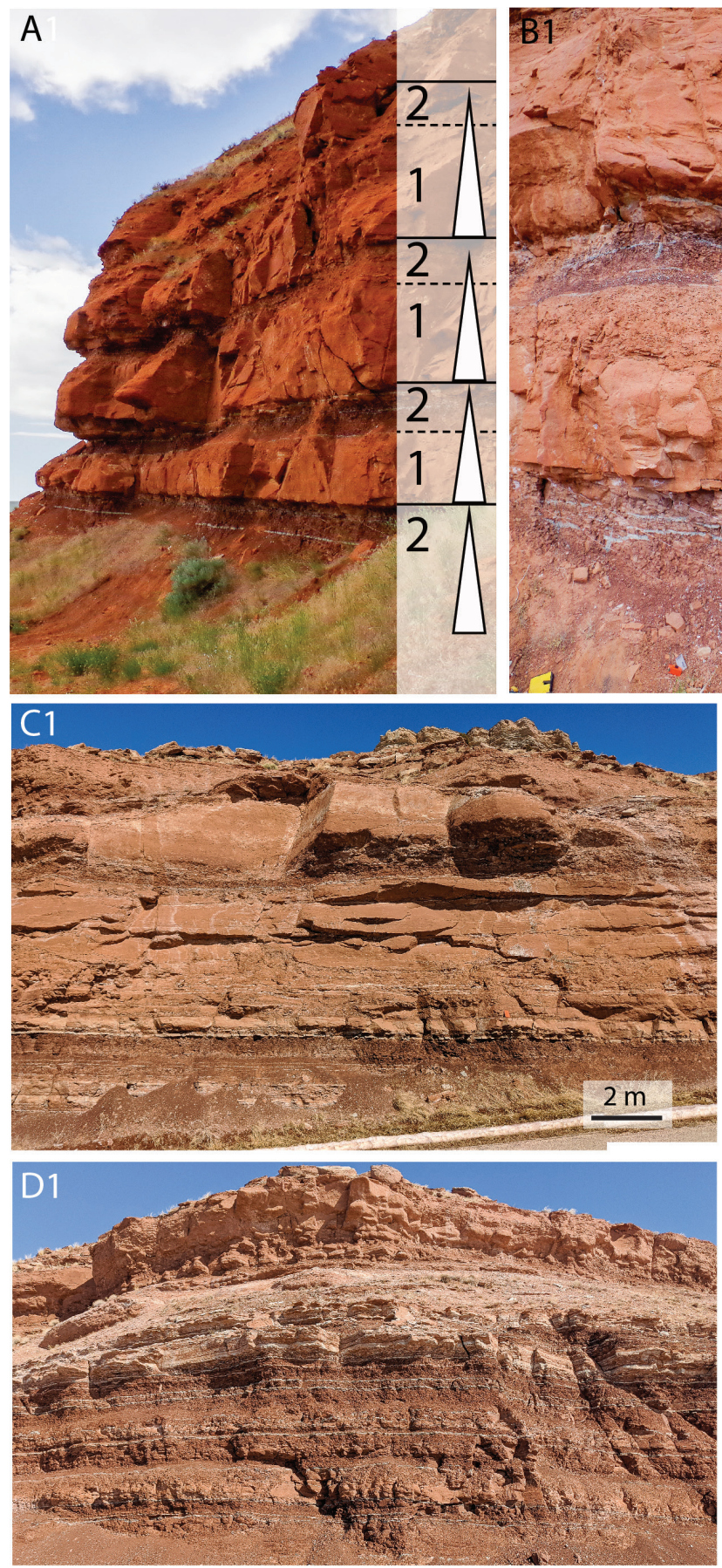
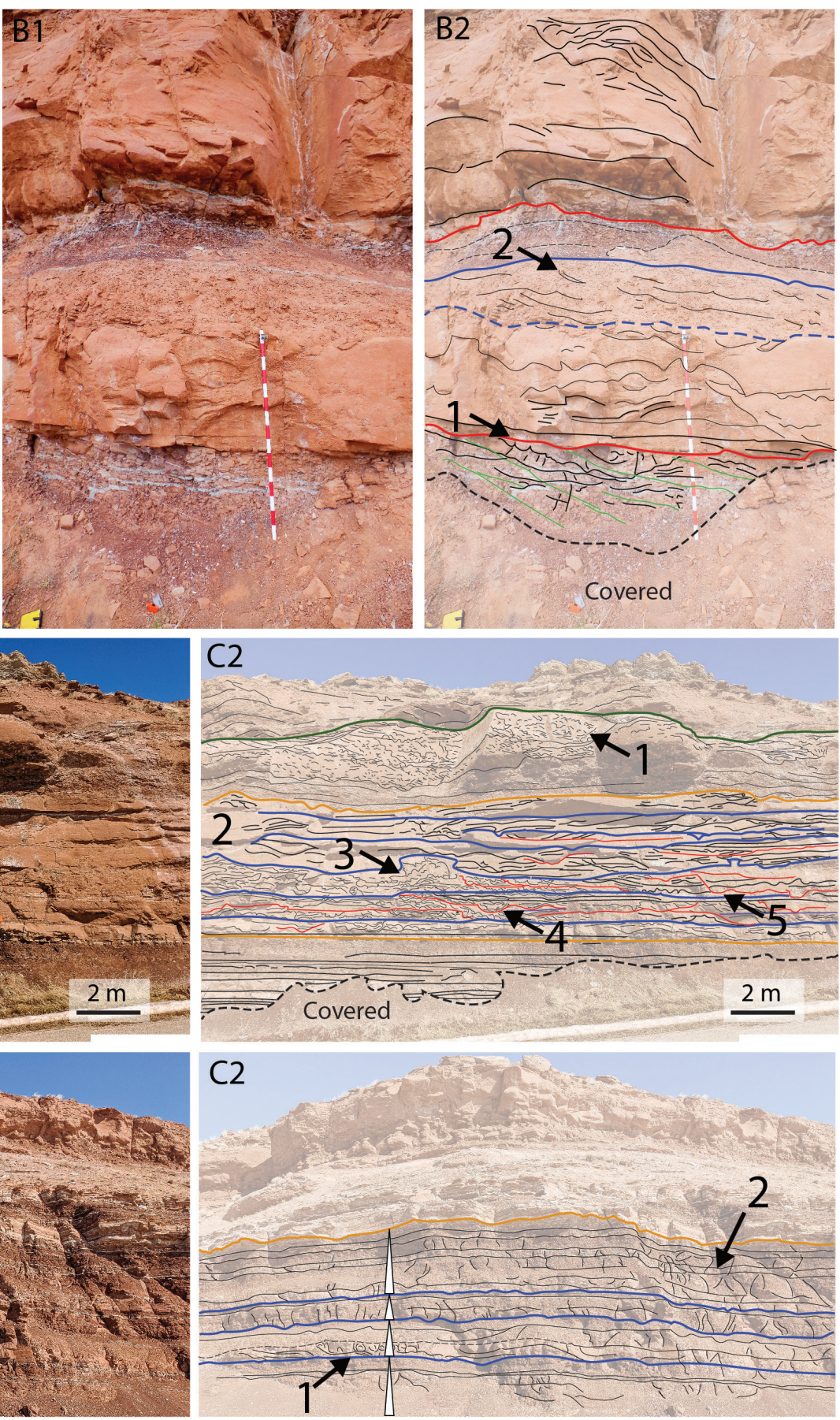
Fig. 6: Detailed stacking patterns and sediment arrangements. Sediment packages of genetically related bedsets (bounded by yellow lines) consist of erosional surfaces (red lines) and first-order (blue lines) or second-order (black lines) accretion surfaces. The alternating lithofacies association at Thermopolis (A) and Willow Hill (B) are couplets of resistant lithofacies (A, no. 1) grading into recessive lithofacies $(A$, no. 2$)$. The bases are erosive $(B 2$, no. 1$)$ with gradational or intermediate contact with the resistant lithofacies (B2, point2). The agglomerated resistant lithofacies association at the Alcova Reservoir (C) has a more complex internal surface arrangement. The upper unit (C2, no. 1), divided into two large bedsets (green line), has disrupted bedding and is possibly unrelated to the bedsets below (C2 no. 2; within yellow lines). Beds have minor soft-sediment deformation and large-scale $(2+m)$ fluid escape structures that deform bedding (C2, no. 3). Beds onlap onto erosional surfaces (C2, no. 4), and erosional surfaces crosscut each other (C2, no. 5). The stacked recessive lithofacies assemblage at the Alcova Reservoir (D) consists of stacks of fine-grained buy fining sets of resistant lithofacies bedsets (C2) upward. Accretion surfaces separate bedsets $(C 2$, no. 1) with no evidence of erosion that is laterally persistent over the outcrop's exposed area. Cracking is often sub-vertical arcing cracks that rarely promulgate across bedset boundaries.

Pedogenic features include cutans, reduction spots, and incipient pedogenic aggregates. Cutans appear like intraformational rip-ups but have angular and irregular boundaries that come to sharp points and often have dark laminations around all edges. Cutans morphology can be massive (Fig. 16B, no. 1) or laminated (Fig. 16C, no.4). Cutans often co-occur with root traces (Fig. 16C, no. 1) and vertical or sub-vertical clay-filled cracking (Fig. 16C, no. 2). Incipient pedogenic aggregates have clay accumulations and circumgranular cracking (Fig. 16D, no. 2).

Reduction spots, blobs, and layers are common (Fig. 7F) diagenetic features. Reduction spots are 1-5 mm in diameter, circular, light greenish-grey (10GY 9/2), and greenish-grey (2BG 8/2) spots, many with a black central point. Reduction blobs and beds are mostly light greenish-white (7GY $8 / 2$ ) to light greenish-grey (10GY 9/2), running roughly horizontal to bedset boundaries but crosscutting sedimentary structures.

Bedsets have sharp upper and lower boundaries (Fig. 6) with a few clear internal structures. The lower boundaries of bedsets are often erosional (Fig. 7I, 12). Bedsets of the resistant lithofacies are extensively laterally continuous. The longest a bedset was traced in outcrop for $6 \mathrm{~km}$ (Fig. 3C, point 1) at Red Valley and likely extended much further after it was last into the subsurface. A distinctive bedset at Shell Creek (Fig. 3A, point 1) is likely the same unit at Alkali Creek (Fig. 3D, point 1), observed in cliff wall outcrops between the two locations $30 \mathrm{~km}$ apart. 


\section{Interpretations}

The resistant lithofacies are interpreted to have been deposited predominantly by unconfined overland flow and weakly confined straight fluvial systems in a low-relief distributive fluvial system. Extensively laterally extensive bed geometries with erosive bases are consistent with deposition in unconfined flow (Fisher et al., 2007; North and Davidson, 2012). More rarely, the channelized flow resulted in lateral accretion and more weakly erosive surfaces (Miall, 1977, 1985; Fielding, 2006). However, the fluvial systems of resistant lithofacies are unusual. The grain size is remarkable for being uniformly fine-grained, more typical of a large meandering system. There is no evidence of mud-drapes, channel abandonment mud caps, tapering levees or overbank deposits, gravel lags, or channel thalweg sands. However, thin and laterally extensive sandstone and siltstone units with only localized channelization are consistent with unconfined overland flow (North and Davidson, 2012) and distal distributary fluvial systems (Nichols and Fisher, 2007).

The extensive nature of the Red Peak Formation bedsets and the similar grain size of bedding are misleading. Although bedsets are continuous, the beds within them are not. Sediment supply was fine-grained (very fine sand and lower), chemically immature sediment. The resistant lithofacies has a paucity of fossils, trace fossils, or microfossils. Reduction spots with a dark center are interpreted to have been caused by local redox conditions formed during the decay of root materials. Adhesive meniscus burrows are diagnostic of modern soil beetle burrows (Hasiotis et al., 2007). Many units have evidence of weak or incipient soil formation, particularly near the tops of beds.

The erosional base of units was likely caused by either high-velocity unconfined flow events or sustained wind erosion of otherwise stable soil surfaces. Erosional surfaces are mostly overlain by possible back-flow ripples, with size and shape indicative of formation in the large unit bar's lee and high velocity and likely rising flow (Herbert et al., 2015). Migration of unit bars results in planer cross-stratified co-sets with tangential foresets onlapping back-flow ripples (Herbert and Alexander, 2018; Herbert et al., 2020). Upper plane regime planer beds over planer tabular cross-bedding and "humpback" cross-bedding further supports events with high flow velocities increasing in depth and velocity as the flow event progresses (Fielding, 2006). Upper plane beds are common in ephemeral rivers and braided streams with infrequent high flow events and large sediment fluxes (Deluca and Eriksson, 1989). Soft sediment deformation, including dish structures and the deformation of beds, indicated subsequent flows could deposit sediment in rapid succession. The resulting laterally extensive unit geometries where erosion and lateral accretion is not present is diagnostic of unconfined flow (North and Davidson, 2012). 
Small-scale lateral accretion, wedge cross-stratification, and trough cross-stratification are consistent with channel bar migration and downstream accretion of channel cross-bars in straight braided fluvial systems, perhaps including reworking by wind (Blakey and Gubitosa, 1984; Miall, 1988). The small-scale lateral accretion, limited erosion, and lack of clay are more typical of straight and braided river systems than meandering systems (Miall, 1977) or distal distributary fluvial systems (Nichols and Fisher, 2007). Cant and Walker (1978) describe the formation and downstream accretion of sand flats during the falling stage of straight fluvial rivers resulting in low-angle down-dip accretionary surfaces, similar to those of the resistant facies. The eroded area would likely be larger than the accretions area, resulting in subsequent flows occurring adjacent to the newly deposited sandflats. Over time the sediment would accumulate across the landscape, filling the accommodation space and resulting in laterally extensive bedsets. Strong winds could further redistribute sediment, contributing to thin and laterally extensive finegrained sediment beds with abundant ripple marks and cross laminations.

\section{Ped-overprinted Mudstones Lithofacies}

\section{Descriptions}

Ped-overprinted mudstones are the most common lithofacies comprising approximately 50\% of the Red Peak Formation. The ped-rich mudstones are a pale, light grayish red (5YR 7/4) to a dark scarlet grey (2.5 YR 4/2) or dark grayish red (5YR 2/2) silty claystones and claystones. Ubiquitous peds define these units (Fig. 8), although remnant erosion surfaces (Fig. 8A, no.1), laminations (Fig. 8G, no. 1), and cross-bedding can rarely be identified through an overprinting of peds. Cross-bedding visible through peds is planer tabular with planer foresets and asymptotic or tangential bases (Fig. 8G, no. 2) or rarer wedge-planer (Fig. 13A, no. 5). There is also rare soft-sediment deformation (Fig. 13A, no. 3, 6).

Patchy areas of reduction are common (Fig. 8A, C, F-G). Reduction spots and reduction layers are common in the recessive lithofacies beds. Reduction layers are discontinuous layers of light greenish-grey (10GY 9/2) and greenish-grey (2BG 8/2) to dark grey (7.5G 4.2). Reduction layers align along horizons roughly parallel to the bed and bedset boundaries but cross-cut peds, sediment structures, and bed boundaries. Reduction spots comprise tabular layers, lines or spots, and blobby areas, roughly forming layers. Reduction spots are circular, 1 - $5 \mathrm{~mm}$ diameter, light greenish-grey (10GY 9/2), and greenish-grey (2BG 8/2) spots. Some reduction blobs extend down from a surface (Fig. 8A) following subtle root traces, creating bifurcating blobby patterns up to $20 \mathrm{~cm}$ long. 

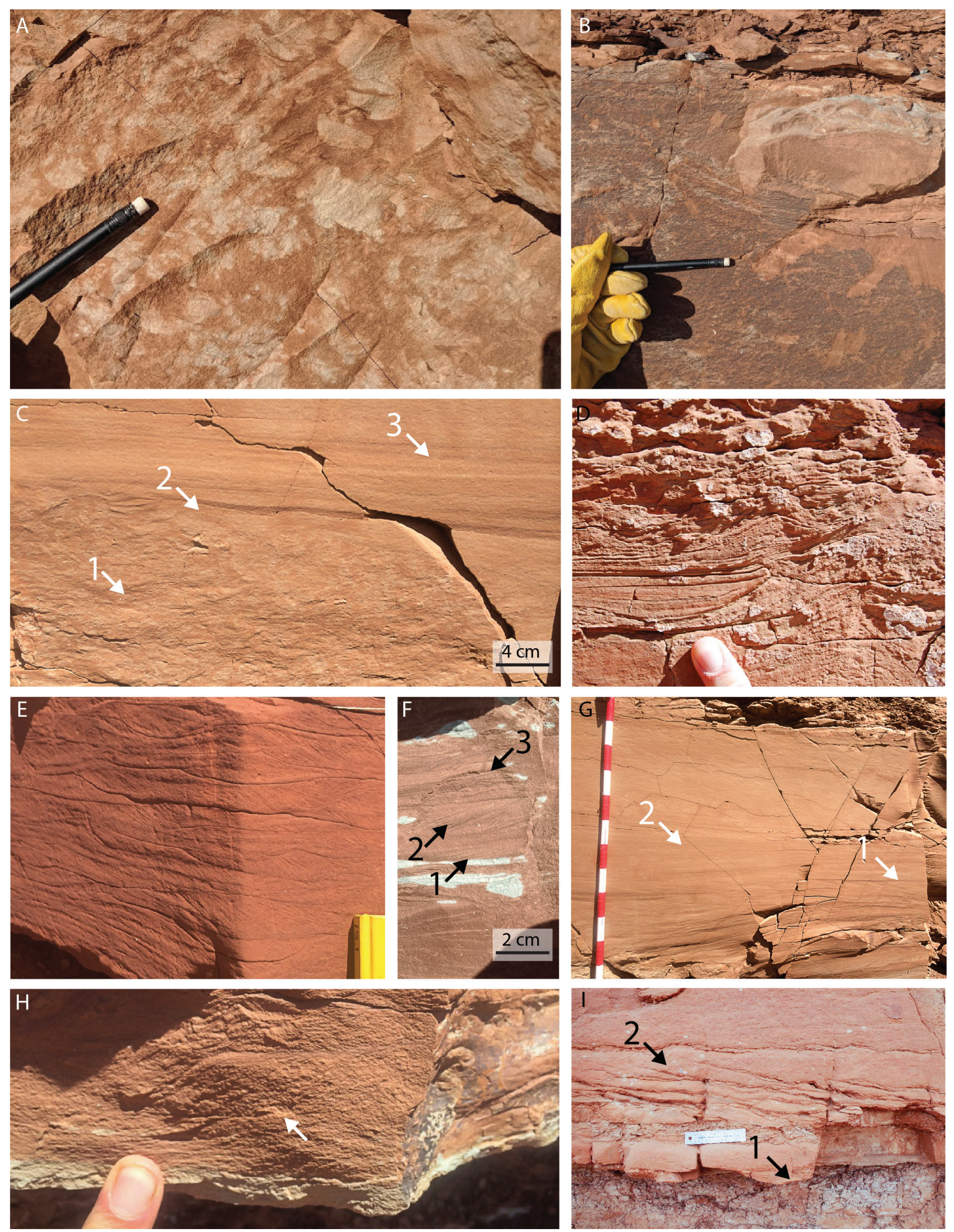
Fig. 7: Details of sedimentary structures and features from resistant lithofacies. (A) Disrupted bedding, likely from bioturbation. (B) Minor soft-sediment deformation and isolated load ball (fine sand ball in siltstone) near the top of a resistant unit. (C) Minor dish structures and disrupted bedding (no. 1), internal erosional surface (no. 2), and upper plane bedding (no. 3). (D) Trough cross-bedding with unidirectional tangential foresets. (E) Three-dimensional view of cross-bedded siltstone showing trough cross-bedding co-sets with tangential unidirectional foresets. (F) Tabular wedge cross-bedding with tangential unidirectional foresets. (G) Rip-up clast lag (no. 1, dark bed) between a planer tabular cross bed co-sets with tangential foresets and cosets of trough cross-bedding with "humpback" morphology preserving the entire dune bedform. The "humpback" cross-beds grade into upper plane beds (no. 2). (H) Detail of planer tabular cross-bedding with tangential foresets. (I) Detail of common unit-boundary geometry with erosional surface overlain by a thin silt unit with backflow ripple bedforms (no. 1) and tangential foresets in a tabular co-set (no. 2).

Peds are 0.25 - $8 \mathrm{~cm}$ long, ovate structures separated by thin matrix membranes (Fig. 8). Peds form by propagating bifurcating arcuate cracks around ovate zones of clay-rich or silt rick circular areas and are characteristic of circumgranular cracks. Peds are either blocky, columnar, platy, or poorly formed. Blocky peds $(<2 \mathrm{~cm})$ are peds of roughly equal size with no clear orientation (Fig. 8A) or wider than tall (Fig. 8B). Platy peds range in size from very small $(<<1 \mathrm{~cm}$; Fig. $8 \mathrm{C}$ ) to small (2 to $3 \mathrm{~cm}$; Fig. $8 \mathrm{G}$, no. 1), are angular, and have a width to height ratio exceeding 2:1. Columnar peds are rare and form vertical stacks (Fig. 8D) of equal-sized or slightly wider than tall peds. Columnar peds have been observed to have soil slickensides and clay skins along cracks at peds boundaries (Fig. 8E). Poorly formed peds (Fig. 13A) do not completely overprint the sedimentary structures below. Some larger beds and bedsets have large arcuate cracks that originate from bedset surfaces and curve towards horizontal at the lower bedset boundary (Fig. 8F, no. 3).

Modal mineralogy calculated from automated mineralogy (Fig. 12, 17) on thick-sections of centimeter-sized rock samples extracted from crumbling outcrops of peds confirmed a mixture of detrital grains in a clay matrix. Detrital grains are comprised of quartz, feldspars, and micas. Clay minerals and detrital grains form a granular texture of small ( $>1 \mathrm{~mm}$ ) soil aggregates with two domains or discrete regions of ped and matrix: (1) detrital minerals are most abundant (Fig. 17B, C, no. 1) and (2) areas where clay minerals are most abundant (Fig. 17B, C, no. 2). In the outcrop, circumgranular cracking defines larger peds that follow the boundaries of the smaller aggregates. The ped domain can be either clay-dominated (Fig. 19A) or silt-dominated (Fig. 19B). Elongate grains, particularly micas and chlorites, orientate parallel to ped surfaces in the matrix and are either randomly oriented or orientated off-axis to the boundary within the ped (Fig. 19C). Ped boundary surfaces are defined by a change in the matrix's composition, a change 
in texture, and sinuous bifurcating circumgranular cracks (Fig. 19A). Some cracks arc around planes of weakness formed at the ped boundary (Fig. 20), while others follow the general orientation of ped boundaries but cross-cut the actual domain boundary. Cracks have a curvature and join in liberating peds from the outcrop; this cracking pattern, controlled by the microscopic in-situ pedogenic aggregates, defines the characteristic surface pattern in the outcrop (Fig. 8).

\section{Interpretations}

The ped-overprinted mudstone lithofacies are interpreted to be paleosols imprinted over previously deposited sediment. Pedogenic features such as peds, soil slickensides, and root traces overprint original depositional features. Paleosol horizons form laterally extensive units parallel to a low-relief paleotopography. These paleosols have a pervasive granular texture comprised of well-developed in-situ pedogenic aggregates. The pervasive lattice-like surface texture (peds) in outcrop is likely a combination of original slickensides and later pressure-release cracks, both macro-scale features having propagated along boundaries defined by the micro-scale aggregates. Soil classification in paleosols is problematic. The outcrop expression of paleosols seems to conflict with the micromorphology. For example, in oxisols, well-developed granular microstructures are typical (Marcelino et al., 2018), and the texture is consistent with well-developed soils

of the class. However, in outcrop, there are few examples of clear horizonation, and the sediment is more chemically immature than would be expected. A reluctance to assign a soil order should not distract from the fact that soil features are entirely terrestrial, and the Red Peak Formation has well-developed soil features. See the discussion section for further analysis of this apparent conflict between the soil's observed structure at the outcrop versus micro scales.

It is impossible to disentangle the original environment of deposition from the later development of the unit's pedogenic features characteristic. It is possible that soil developed on pre-existing fine-grained sediment or that the sediment became more fine-grained through pedogenesis. Overbank deposits, lacustrine setting, the fine-grained caps on waning turbidity flows, and windblown sediment can also deposit fine sediment. The ped-overprinted mudstone lithofacies likely developed on some combination of these.

\section{Bedded Gypsum Lithofacies}

\section{Descriptions}

Bedded gypsum and anhydrate (hereafter referred to as gypsum) occurs in two forms: (1) successions of planer parallel units of bedded gypsum with thin red mudstone interbed (Fig. 9A, B); and (2) as thin isolated units within ped-overprinted mudstone (Fig. 9C, D). A $6 \mathrm{~m}$ to $12 \mathrm{~m}$ thick unit of alternating beds of red claystone and gypsum bedsets is approximately $15 \mathrm{~m}$ below 
the Alcova Limestone in the Bighorn Mountains at Bighorn Lake, GP Gypsum, and Greybull locations. This gypsum and red claystone unit were absent at the Shell Creek locality and all localities south and east of Shell Creek (Fig. 5). In this thick red mud and gypsum unit, bedded gypsum bedsets are between $10 \mathrm{~cm}$ and $20 \mathrm{~cm}$ thick with beds between $1 \mathrm{~cm}$ and $3 \mathrm{~cm}$ thick. Red mud beds are between $2 \mathrm{~cm}$ and $10 \mathrm{~cm}$ thick and are often cross-cut by gypsum stringers. Thin isolated gypsum units are less than $20 \mathrm{~cm}$ thick, rarely bedded or laminated, and only occur within units of ped-overprinted mudstone. Thin isolated units pinch out or cannot be followed due to weathering. All gypsum bedding or laminations are diffuse planer parallel or diffuse wavy parallel bedding, and the gypsum has a course crystalline or sugary texture.

\section{Interpretations}

The successions of bedded gypsum and red mud are interpreted to have originated in a saline lake. Like most ancient gypsum, this gypsum may have undergone several dehydrated and hydration events, resulting in the coarse crystalline texture and the obscuration of original textures. However, the gypsum units are bedded, suggesting deposition in a saline lake either as accumulations of cumulate crystals into beds or bottom growth crystals. It is also possible that beds of gypsum were eolian. However, the bedding and laminations in nearly all units are planer or wavy parallel, not the cross-bedded eolian gypsum. Additionally, thick beds of red clay-sized mud accumulating between gypsum units are common in saline lakes and could be deposited on mudflats from unconfined overland flow, from suspension settling in lakes, or from authigenic silicate precipitation in lakes (Lowenstein and Hardie, 1985; Benison and Goldstein, 2000; Benison et al., 2007; Calvo et al., 2009).

Thin beds of laterally discontinuous gypsum could be eolian, gypsum soil horizons, or deposited in saline lakes. Because these units are associated with the ped-overprinted mudstones, a soil origin is supported, and red laminations and bedding support a lacustrine origin. All three environments are associated with arid climates, and it is possible that all three environments were present. All possible origins indicate a climate where evaporation exceeds precipitation, but further specificity on the formation environment is not possible.

\section{Laminated Mudstones Lithofacies}

\section{Descriptions}

Red or variegated laminated mudstones are rare but exist more commonly near the base of the Red Peak Formation (Fig. 10). Units are laminated or rarely bedded variegated siltstone and claystone that range in color from light orange (7.5 YR 7/4) and brick red (10R 6/14) to dark red (5YR 3/4) and reddish black (10 YR 2/2). Units range in thickness from $20 \mathrm{~cm}$ to $200 \mathrm{~cm}$. Lam- 

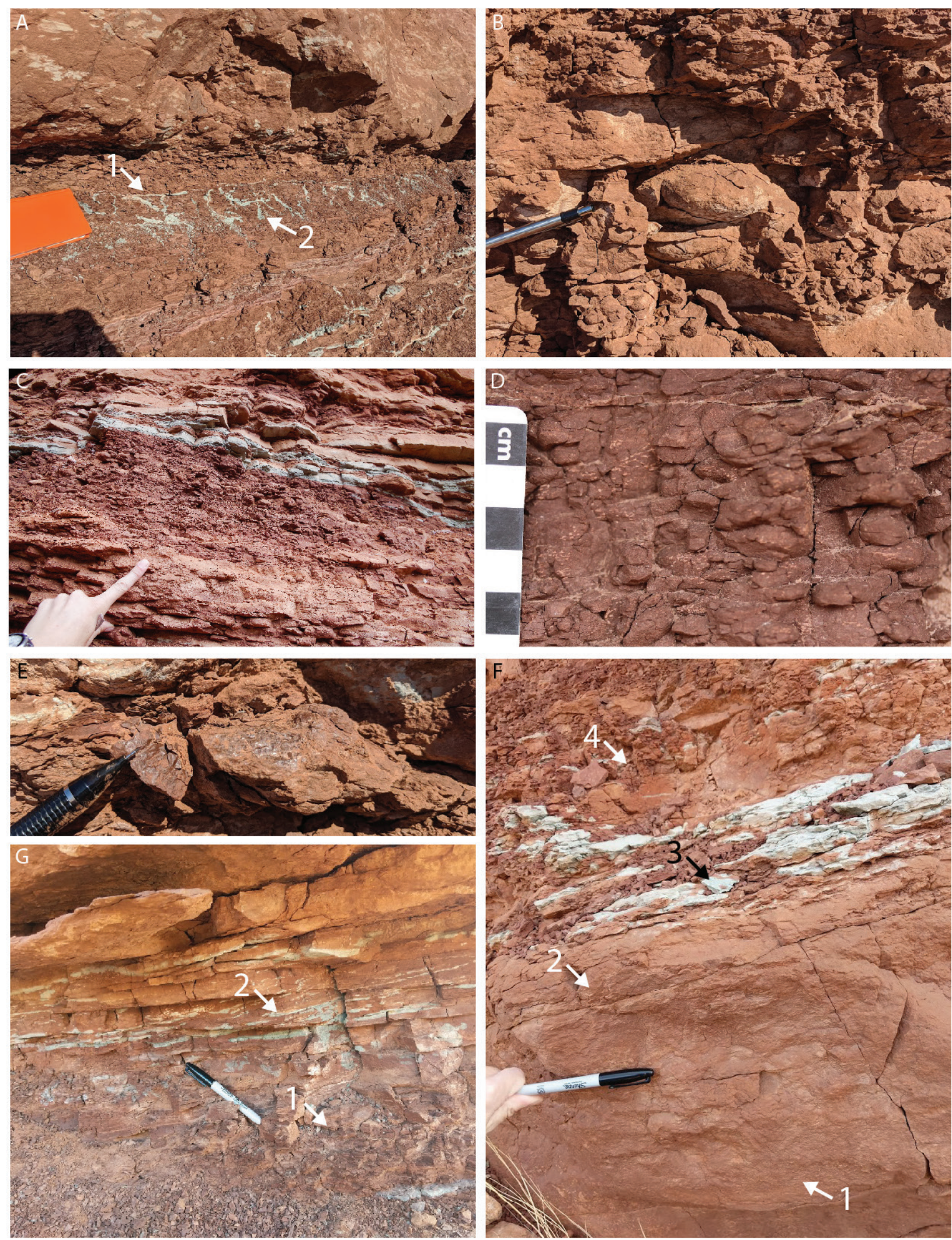
Fig. 8: Details of sedimentary structures and features from ped-overprinted mudstone lithofacies. Structures and features include internal erosional surfaces (A, no. 1), root features $(A, n o .2)$, blocky peds (B, F, no. 4), platy peds (E; $G$, no. 1), columnar peds (D), clay skins (E), reduction spats and blobs $(F$, no. 3). The lower boundary of ped-overprinted blocky peds is often gradational (C; F, no. 2). White upper boundaries are often erosional with planer tabular cross-bedding with tangential foresets onlapping onto the surface $(G$, no. 2$)$.

inae are from $5 \mathrm{~mm}$ to sub-millimeter thick with rare beds of siltstone to $1.5 \mathrm{~cm}$ thick. Continuous, planer parallel laminae with indistinct boundaries are common (Fig. 10C) and wavy, pinch and swell, or discontinuous lamina are rare (Fig. 10A-B). Most laminae are found as couplets of thicker siltstone and thinner claystone.

\section{Interpretation}

Millimeter scale laminae of alternating siltstone and mudstone indicate deposition in either a low-energy subaqueous environment from suspension settling or episodic high-energy sub-aqueous events between background low-energy sedimentation. This deposition style is possible in both fluvial systems as overbank or flood plain deposits or in lacustrine settings as suspension settling or turbidity currents. The laminated mudstone facies are interpreted to be deposited in a lacustrine setting.

Couplets of silt- and clay-sized particles are typical of perennial lakes where seasonal variations in climate control water and sediment influx (Yechieli and Wood, 2002; Hardie et al., 2009; Matter and Tucker, 2009). Siltstone lamina is typically thicker than claystone lamina, have no internal structures or bedforms, and are not gradational, indicating they are not formed in turbidity current or event beds. Most beds are red or orange, suggesting that bottom waters were not reducing or in an otherwise low-oxygen environment. The lack of bioturbation, soil overprinting, mud cracks, or other exposure indicators further supports an interpretation of a saline lake environment hostile to benthic life.

Laminated couplets can also form in flood plain deposits in fluvial systems. Couplets in fluvial systems form from periodic flooding outside of the confines of the channel. It is typical of flood plain and overbank deposits to originate from a channel-levee complex and thin laterally, tapering and becoming finer with distance. (Posamentier and Walker, 2006; Fisher and Nichols, 2013; Shen et al., 2015). The laminated mudstone lithofacies are laterally extensive and do not taper with distance, and have not been observed to have any relationship to possible channels. It is common for sand or coarse silt to originate from turbidity currents or sheet flows and have sharp non-erosive bases, gradational tops, and features such as load casts, plant fossils, cross-lamina- 

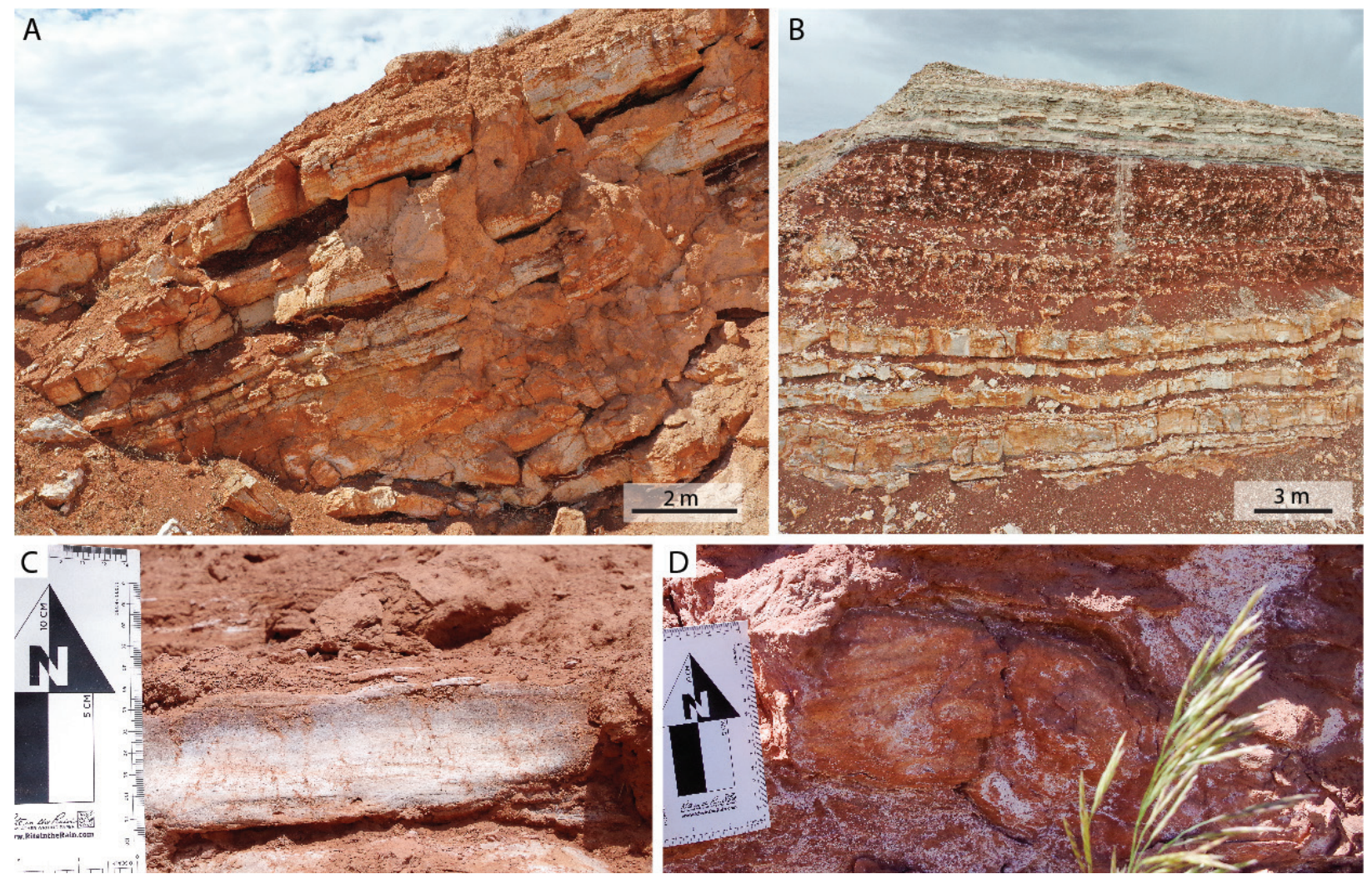

Fig. 9: Details of gypsum in outcrop. (A) Bedded gypsum at Greybull and (B) GP Gypsum localities. Gypsum is interbedded with red claystone. (C) Thin (>20 cm) gypsum beds within the ped-overprinted mudstone lithofacies pinch at Bessemer Bend and (D) Alcova Reservoir. All gypsum typically has 1 to $3 \mathrm{~cm}$ thick gypsum beds separated by indistinct red laminae. Thin gypsum layers within the ped-overprinted mudstone lithofacies typically pinch out within a few meters. tions, and small-scale trough cross-bedding (Fielding, 1986; Colombera et al., 2013). None of those features are present in the laminated mudstone facies, and although overbank or flood plain deposits are possible, this is unlikely.

\section{Siltstone and Sandstone Lenses Lithofacies}

\section{Descriptions}

Lenses of resistant siltstone and rare very fine sandstone are commonly associated with ped-overprinted mudstones and laminated mudstones. The resistant beds within siltstone units are thin (less than $10 \mathrm{~cm})$, light red (2.5YR 7/8) to dusky orange (10R 5/8) siltstones, sandy siltstones, and rare very fine sandstones. Beds most commonly have sharp erosional bases and irregularly grade into surrounding units (Fig. 11A). Rare beds have sharp upper and lower bounding surfaces. Most units consist of a single bed between $2 \mathrm{~cm}$ and $5 \mathrm{~cm}$ thick that pinches out laterally within a few meters. Commonly, units are trough cross-bedded (Fig. 11B, C) or have evidence of soft-sediment deformation. Asymmetric ripple marks and mudcracks are common on bedding plane surfaces (Fig. 11D). 


\section{Interpretations}

The siltstone and sandstone lenses are interpreted to be deposited in either unconfined flow events in subaerial environments or turbidity currents in a sub-aqueous environment. The erosional bases, soft-sediment deformation, gradational tops, current ripples, and trough cross-stratification indicate deposition in an initially strong, subsequently waning current. Mudcracks indicate exposure after deposition, favoring unconfined flow in sub-areal environments. However, turbidity currents down slopes in ephemeral lakes or as crevasse splays on flood plains could be followed by post-depositional exposure. Three environments of deposition are possible: (1) sand flats or mudflats adjacent to ephemeral lakes, (2) sub-aqueous lacustrine environments, and (3) fluvial overbank or crevasse splay environments.

Hardie et al. described sandflats surrounding saline lakes as the distal toes of alluvial fans where the unconfined flow from flooding events has moved sediment from the fans and into the lake basins. This sediment is then often re-worker by wind, creating "cut-and-fill structures, low-angle inclined bedding, and heavy mineral lag laminae. Small wind-blown dunes, with avalanche cross-bedding, slump structures, may march across the sandflat and up the fan toe where they may coalesce into a large dune field." Floods rarely bring silt and sand-sized particles into the central part of saline pan environments (Lowenstein and Hardie, 1985), but it is possible for slope failure or confined flow to introduce turbidity currents into saline lakes (Eugster and Hardie, 1975) or for sediment to reach the center of small ephemeral lakes (Benison et al., 2007). The thin lenses of sand are not consistent with a thick apron of sand at the toe of a large alluvial fan, but some sand lenses could be related to turbidity flows into subaqueous saline lakes.

Thin sands can be deposited on overbanks of flood plains as tabular or lenticular sandstone or siltstone bodies with sharp or slightly erosional bases, gradational tops, cross laminations, cross-bedding, mudcracks, and pedogenic features. These features form from unconfined flow over levee deposits or crevasse splays through levees' failure (Wolman and Leopold, 1957; Fielding, 1986; Posamentier and Walker, 2006). That most thin units are associated with ped-overprinted mudstones and have evidence of exposure, most siltstone and sandstone lens units are likely the results of unconfined flow events. However, turbidity currents are also possible, and both environments may have contributed. 


\section{Alternating Lithofacies Association}

\section{Description}

The alternating lithofacies association (Fig. 6A, B) is comprised of recurring couplets of resistant lithofacies (Fig. 6A, no. 1) that grade into recessive ped-overprinted mudstone lithofacies (Fig. 6A, no. 2). The alternating lithofacies are a distinctive feature of every outcrop (Fig. 4, 5, 12). Couplets of bedsets can be traced across the outcrops for kilometers (Fig. 3). One bedset couplet approximately $10 \mathrm{~m}$ below the Alcova Limestone was traced for $9 \mathrm{~km}$ between the Red Valley and Lander, Wyoming.

Couplets of the alternating lithofacies association have an erosional base (Fig. 6B, red line). Beds of resistant lithofacies either onlap into this surface in low-angle down-dip accretionary surfaces or are bounded at the base by a tabular cross bed co-set with tangential onlapping forsets onto a massive thin bed. It is common for this thin massive unit to have back-flow ripples. Resistant lithofacies beds form bedsets between $20 \mathrm{~cm}$ and $3 \mathrm{~m}$ thick that grade into recessive beds. The transition between the resistant and recessive can be characterized by either a transitional zone (Fig. 6B, no. 2) with pervasive pedogenic features and a sharp conformable contact with the (Fig. 6B, blue line), or a relatively sharp conformable non-erosive boundary (Fig. 12). Resistant beds do not have internal erosional surfaces with high-angle lateral accretion. Ped-overprinted mudstone lithofacies bedsets are thinner than the resistant lithofacies beds in the same couplet. Most recessive units comprise one to three horizontal conformable "beds" defined by ped size and shape.

Three bedset couplets were selected from the alternating lithofacies association at the Willow Hill locality and subjected to detailed microanalysis to understand the compositional and textural differences between the lithofacies (Fig. 12). The amount of quartz decreased from the resistant unit to the ped-overprinted unit in each pair. For example, there was approximately $25 \%$ quartz in the resistant bed of bedset one and approximately 5\% in the recessive bed of bedset two. The resistant beds in bedsets two and three had $25 \%$ and $30 \%$ of quartz, respectively, and the recessive beds have $11 \%$ and $15 \%$. Total clay mineral content accounted for between $29 \%$ and $31 \%$ of the thin section's area in the resistant lithofacies. Clay occurs as clay or iron-rich groundmass areas between other grains (Fig. 16, Fig. 18C, point 1) and intraformational rip-ups (Fig. 18C, point 2). Clay in the ped-overprinted mudstone facies ranged from $41.28 \%$ to $54.91 \%$ and occurred mostly as an intergranular matrix in situ pedogenic mud aggregates. Cement is much more common in resistant beds. For example, in bedset two, the tin section's cement area decreases from approximately $6.7 \%$ in the resistant bed to $0.2 \%$ in the recessive bed. 


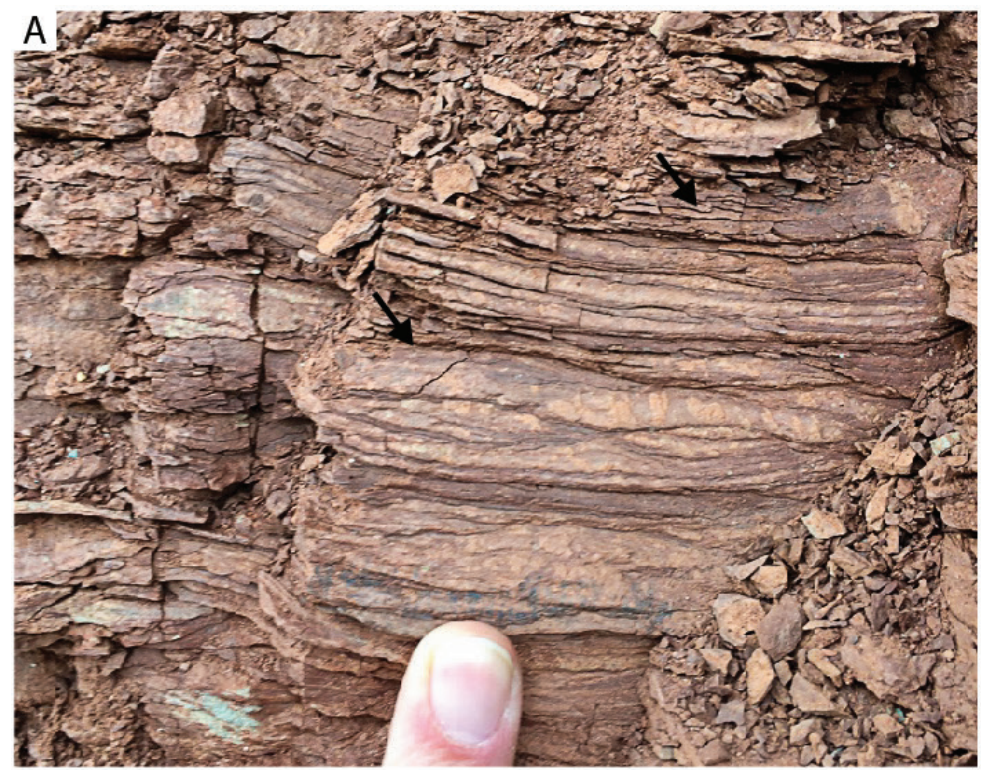

Fig. 10: Select examples of the laminated mudstone lithofacies. (A) Wavy bedding at the Willow Hill locality. (B) Convolute bedding at Thermopolis. (C) Hetrolitic laminae with couplets of siltstone and claystone at the Alcova Reservoir. This laminated mudstone is common, with siltstone laminae and rare siltstone beds thicker than claystone laminae.
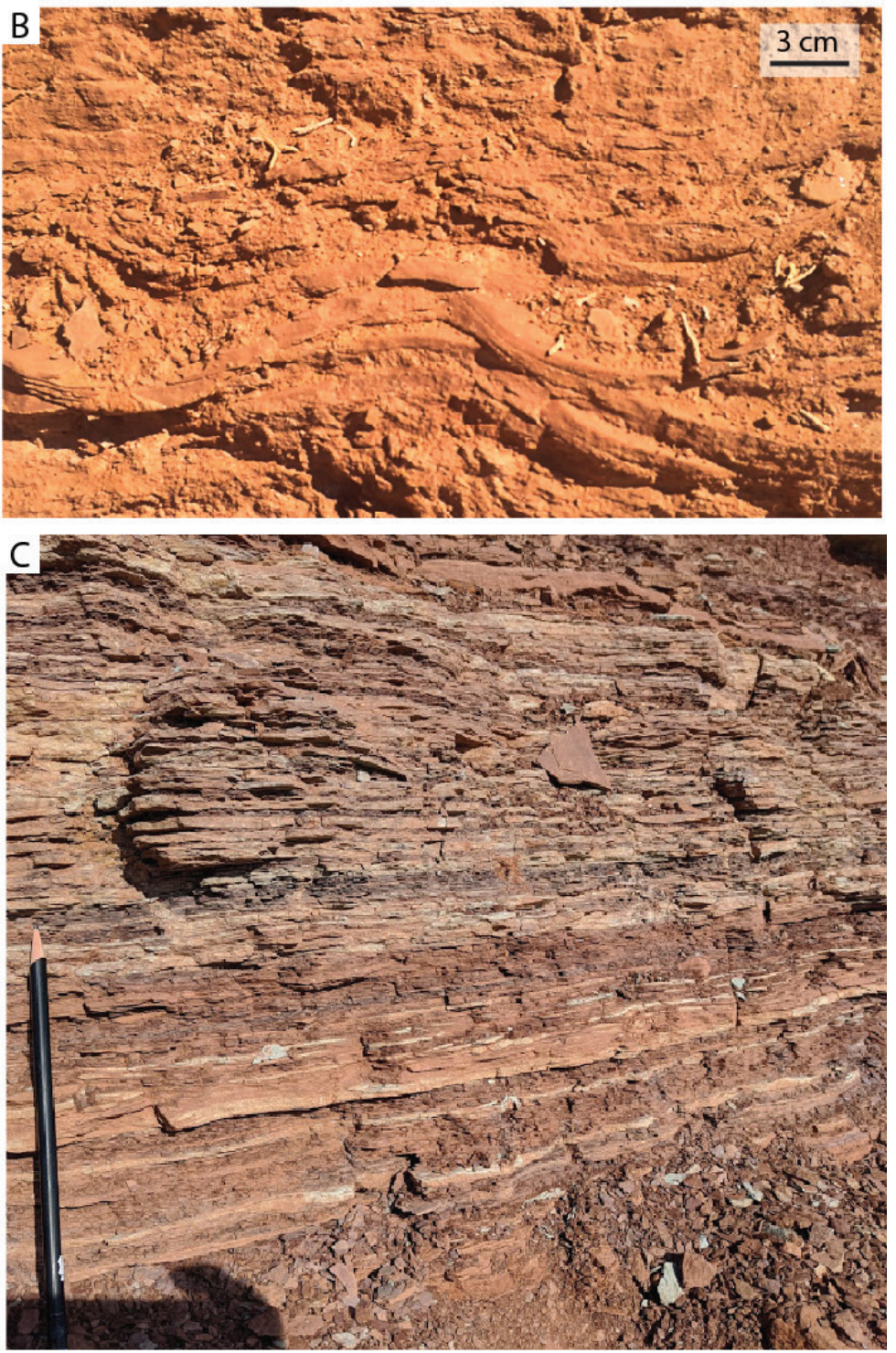

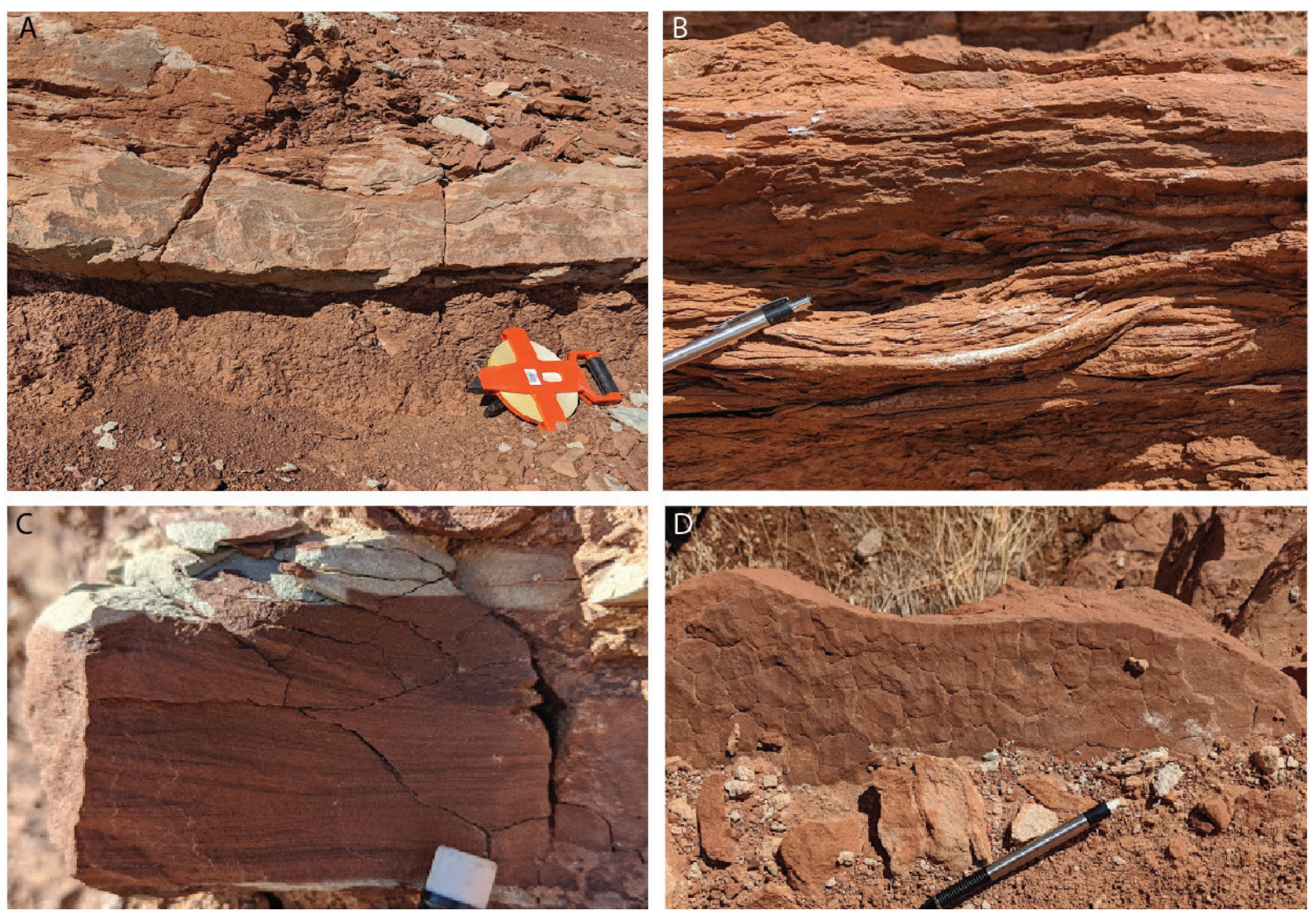

Fig. 11: Details of siltstone and sandstone lenses lithofacies. (A) Laterally continuous thin bed at the Alcova Reservoir with an erosional base and a gradational upper boundary. (B) At Willow Hill, sets of wave-ripple trough cross-laminae over an undulatory base, opposing unidirectional sets of ripples are up to $2 \mathrm{~cm}$ high with common draping of laminae over the ripple crest. (C) At Thermopolis, small-scale (>1cm) sets of trough cross-laminae and (D) polygonal mudcracks on bedding plane view of the same unit. 
The three bedsets chosen for detailed analyses were also subjected to grain size observations. Feldspars and quartz's relative size distribution was used to understand trends in grain size based on mineralogy. Feldspars' relative grain size did not change in bedset one, trended towards larger in bedset two, and significantly tended towards smaller in bedset three (Fig. 14). Recessive beds have a higher percentage of very fine silt-sized quartz (Fig. 15). For example, in bedset two, the fine silt increase from approximately $14 \%$ to approximately $42 \%$ coincided with reducing the sand and clay-sized particles. Although the percentage of course grains decreased, larger grains were still present in all samples. The highest percentage of fine sand was the second recessive unit of bedset, three at approximately $2 \%$.

\section{Interpretations}

The alternating lithofacies association is interpreted to have been deposited as a distal distributary fluvial system. Thin, laterally extensive siltstone and sandy siltstone units with weakly erosional bases are deposited by unconfined flow (Fisher et al., 2007). When sporadic sediment supply and aggregation exceeded soil formation rates, resistant lithofacies are deposited (Fig. 21). When the sediment supply rate is less than the soil formation rate, the sediment is altered into well-developed soil. Insufficient evidence exists to disentangle climatic from tectonic controls on sediment supply variations. It is also possible that the locus of sediment supply migrated across the environment filling accommodation space.

Each couplet was deposited in one or more flow events subsequent alteration by the pedogenic process. The deposition of sediment from an erosion surface to the subsequent erosional surface was a single genetically related flooding event where sediment delivery occurred faster than pedogenic processes can alter the entire profile (Kraus and Aslan, 2009). The reduction in grain size is most likely related to pedogenesis or fine-grained deposition that was subsequently altered by pedogenesis. Fine-grained deposits can occur from deposition during waning flow conditions or lower-energy to slack fluid movement during overbank flooding events. It is also possible that damp soil surfaces act as traps for wind-blown sediment.

Major sediment delivery events were sporadic, separated by long periods during which soil formation was the dominant process. However, during soil formation periods, sediment could be delivered into the system, by unconfined flooding or eolian mechanisms, at rates at which aggradation is less than the rate of soil formation. The landscape would continue to aggrade, and soil horizonation may result. The development of granular soil is inductive of either wet-dry cycling or hot-cold cycling in an oxygenating environment (Buol and Eswaran, 1999), but are not diagnostic of other climatic or environmental conditions. 


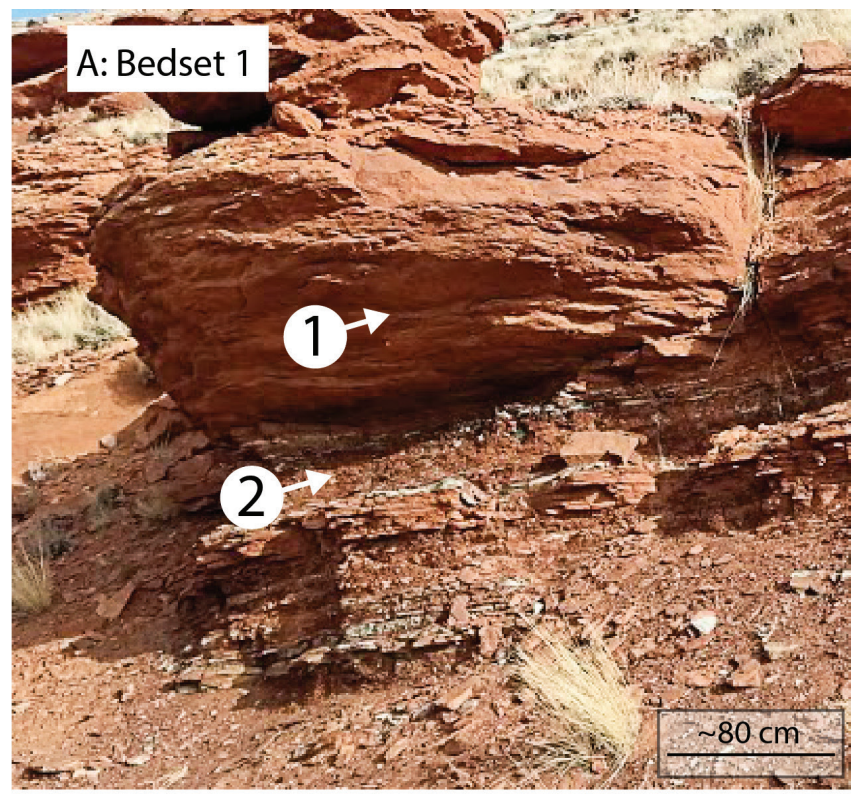

C: Modal Mineralogy

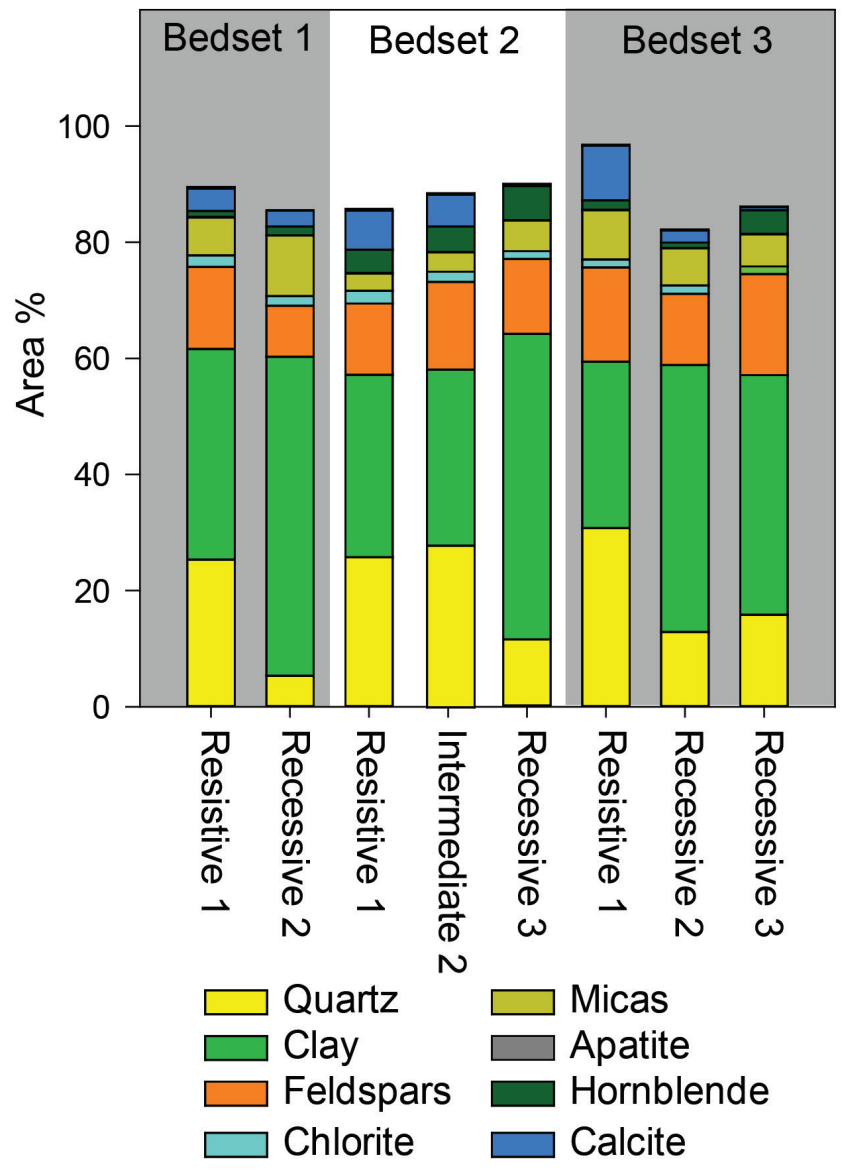

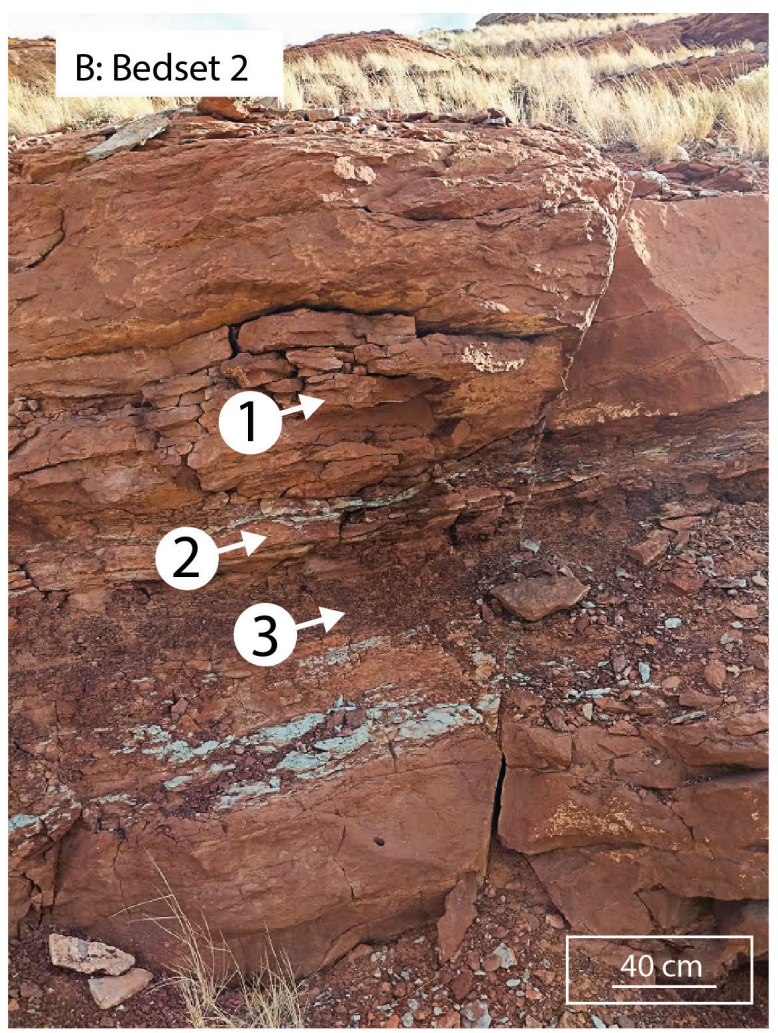

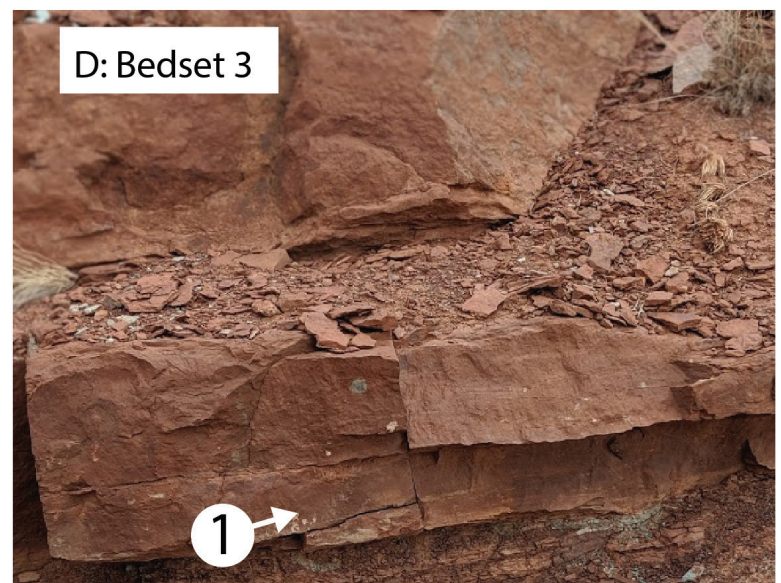

(2)

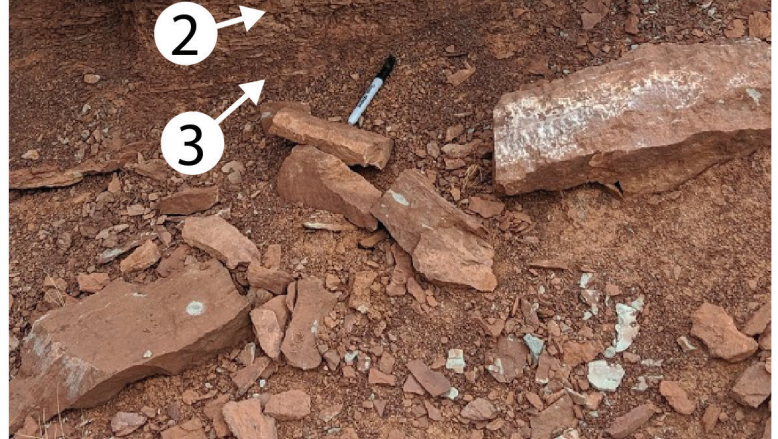

Fig. 12: Three example bedset couplets from the alternating lithofacies association and modal mineralogy. Numbers indicate the exact location of samples. 
The reduction in quartz grain size most likely represents significantly more dilution (through the growth of clays that take up more volume) and translocation of quartz through pedogenic processes and in-situ clay formation than a reduction in the transported grain size from surface processes. As grains of feldspars, appetites, micas, and other detrital grains were chemically weathered to clay minerals, the clays' surface area and volume increased, resulting in the dilution and relative reduction in grain size of the pedon (Doerr et al., 2011). The translocation of grains can reduce the relative grain size through larger grains' physical dilution with smaller ones. The alteration of small grains to clays can also occur. The alterations of the smallest particles of quartz require an explanation that is not clear.

Unconfined flow is possible in many environments. Unconfined flow in the presence of abundant fine-grained sediment could have resulted in a four-step process: (1) small-scale erosion over a wide swath with initial flows; (2) forward migration of mega ripples or dunes creating backflow ripples and planer cross-beds, (3) waning flow deposits the bulk of the sediment, and (4) pedogenesis results in the reduction of grain size and overprinting of pedogenic features. Flows likely originate from a point where channelization is overcome by topographic changes on the slope of a large alluvial fan (Davidson et al., 2013). Unconfined flows will switch across the local topography, filling accommodation space and forming an aggregational pattern. Eventually, sediment deposition's active area will "lobe switch" due to evulsions up-stream, and the active channel area will be abandoned.

\section{Agglomerated Resistant Lithofacies Association}

\section{Description}

Stacked bedsets of resistant beds form the agglomerated resistant lithofacies association. The agglomerated resistant lithofacies association was observed at all locations (Fig. 4, 5) but are thicker and more common to the south. The agglomerated resistant lithofacies are bounded by conformable surfaces (Fig. 6C, orange lines) to delineate laterally extensive units within the outcrop scale. Bedsets are separated by conformable surfaces (Fig. 6C, blue lines) bounding "stories" of genetically related beds. Sediment stories are mostly laterally extensive but can be distorted by soft-sediment deformation. Within each bedset story are erosional channels, lateral accretion, soft-sediment deformation, and bedding (Fig. 6C, no.5).

Channel deposits are defined by cross-cutting erosional surfaces filled with onlapping or laterally accreting beds. Many beds onlap onto erosional surfaces in low-angle down-dip co-sets (Fig. 6C, 
no.4). Beds have preserved cross-bedding, including wedge cross-bedding and cross-bedding, and trough cross-bedding. Soft sediment deformation is common, including meter-scale fluid escape structures into surrounding stories (Fig. 6C, no. 3) and entire beds with disrupted bedding (Fig. 6C, no. 1).

\section{Interpretations}

The agglomerated resistant lithofacies association is interpreted to be deposited in a weakly channelized alluvial system. Stacked stories of amalgamated channel complexes with little or no associated fine-grained overbank deposits are characteristic of proximal facies in fluvial distributary systems (Nichols and Fisher, 2007). That the channel and lateral accretion sediment architecture forms from siltstone are likely indicative that only very-fine sand-sized particles and smaller were available, or that pedogenic mud aggregates of siltstone and claystone acted as sand-sized particles but resulted in lithofacies of fine-grained rock (Gierlowski Kordesch and Gibling, 2012).

The channels were likely straight and braided fluvial channels or a distributive weakly erosive distributive fluvial system on an alluvial fan. Straight braided rivers are suggested because the channels show preservation of bar structures, downstream accretion, miner erosional surfaces, and cross-bedding but do not have the large erosional surfaces and large-scale lateral accretion of meandering rivers. The rapid downstream accretion of siltstone bodies during the drawdown of flows resulted in lateral accretion, trough, and wedge cross-beds (Cant and Walker, 1978; Mitten et al., 2020). The rapid emplacement of sediment resulted in load structures and soft-sediment deformation. The lack of overbank deposits is likely the result of the continual migration of the channels across the landscape or the continual migration of channels across the landscape.

\section{Recessive Lithofacies Association}

\section{Description}

The recessive association is (Fig. 6C) consists of stacked stories of bedsets of ped-overprinted mudstone lithofacies, bedded gypsum lithofacies, and laminated mudstone lithofacies separated by conformable continuous surfaces (Fig. 6C, blue lines). Beds of siltstone and sandstone lenses lithofacies are also common. This lithofacies association is present at most large outcrops. This lithofacies association is a slope-former and is most prevalent at the Red Peak Formation's base (Fig. 5), where it may be indistinguishable from the Goose Egg Formation. 

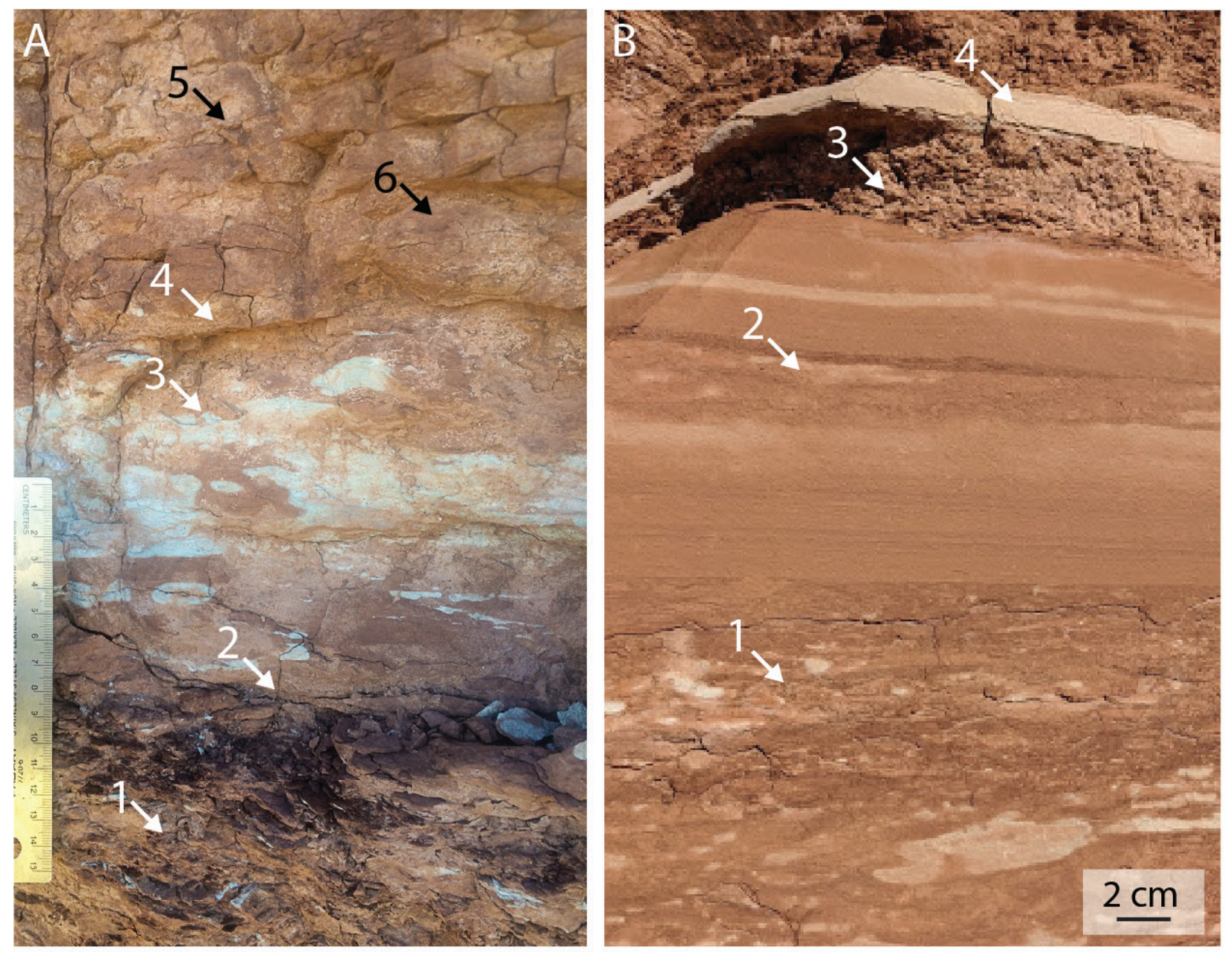

Fig. 13: Recent exposures providing examples of complex relationships of sedimentary features normally hidden by erosion. (A) Profile of complex bedset at Red Valley exposed by rockfall. Platy peds (no. 1) truncated by an erosional surface (no. 2) overlain by a massive unit with reduction blobs (no. 3) minor soft-sediment deformation (no. 4), trough cross-bedding overprinted by pedogenesis (no. 5), and a load cast (no. 6). (B) A profile through a thick succession of recessive lithofacies at Alcova Reservoir newly exposed from a rockfall. Disrupted beds at the base (no. 1) could have been disrupted by sediment loading, bioturbation, or even seismic activity. Upper plane beds (no. 2) are separated from massive muddy units by an erosional surface (no. 3). A thin sand lens (no. 4) within the thicker muddy unit with sharp upper and lower boundaries. 
Fig. 14: Feldspar bestfit circle grain size distribution in Wentworth (1) and weight percent retained (2) for samples from alternating lithofacies association couplets. Bedset one (A) has nearly identical grain size distributions for quartz. Resistant beds in bedset two (B) and bedset three (C) both have a decrease in clay-sized feldspars, likely from the conversion of smaller feldspars with more surface area to clays.
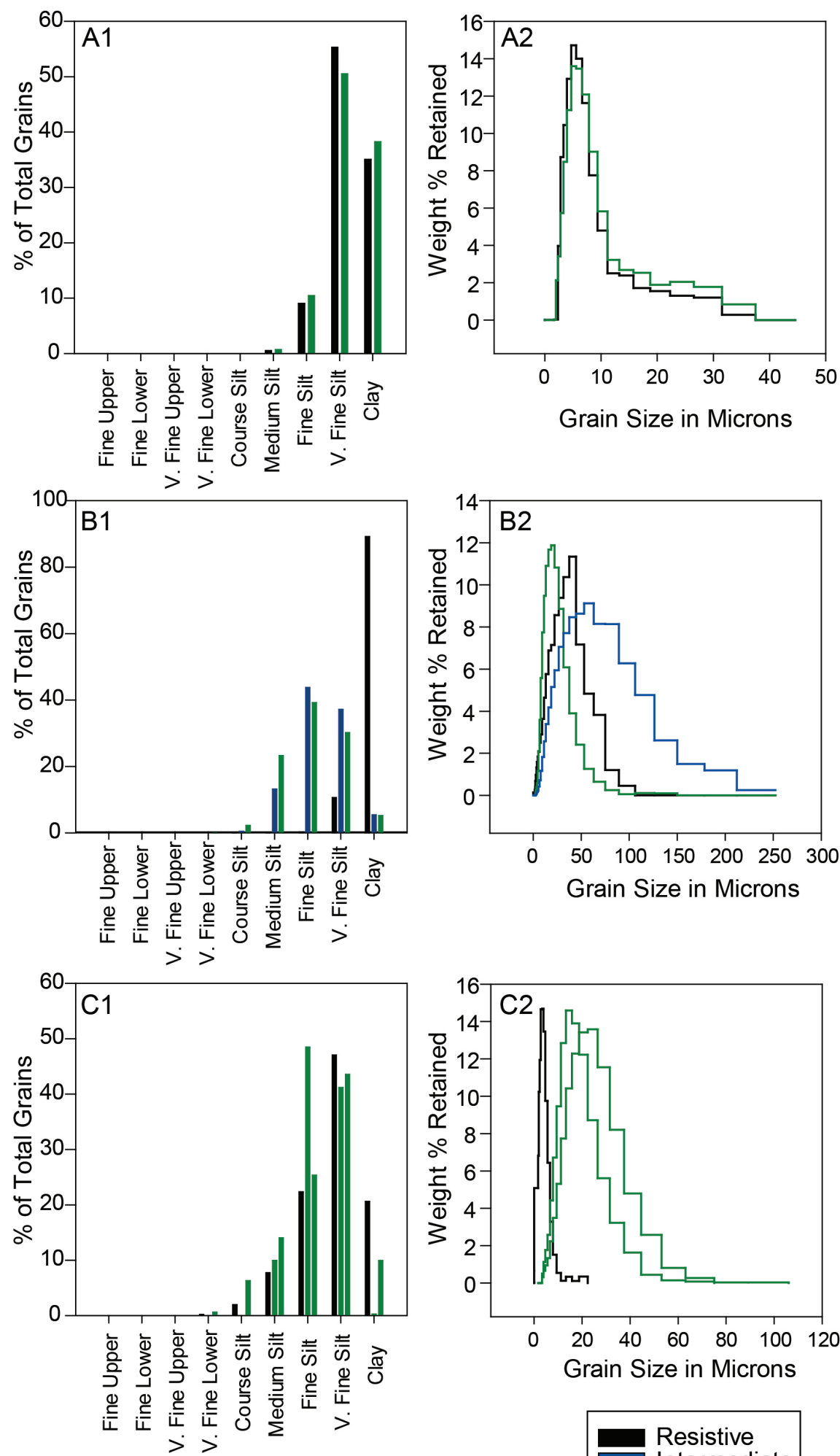
Fig. 15: Quartz best-fit circle grain size distribution in Wentworth (1922) (1) and weight percent retained (2) for samples from alternating lithofacies association couplets bedset one (A), bedset two $(B)$, and bedset three (C). All three show a marked reduction in the amount of courser grain sizes and an increase in the relative proportion of fine sizes from the resistant beds to the recessive beds. This redistribution of grain sizes is likely attributable to dilution effects as clays form and infiltrate smaller dust into the soil. Although dilution has occurred, larger grain sizes, up to $200 \mu \mathrm{m}$, are still present
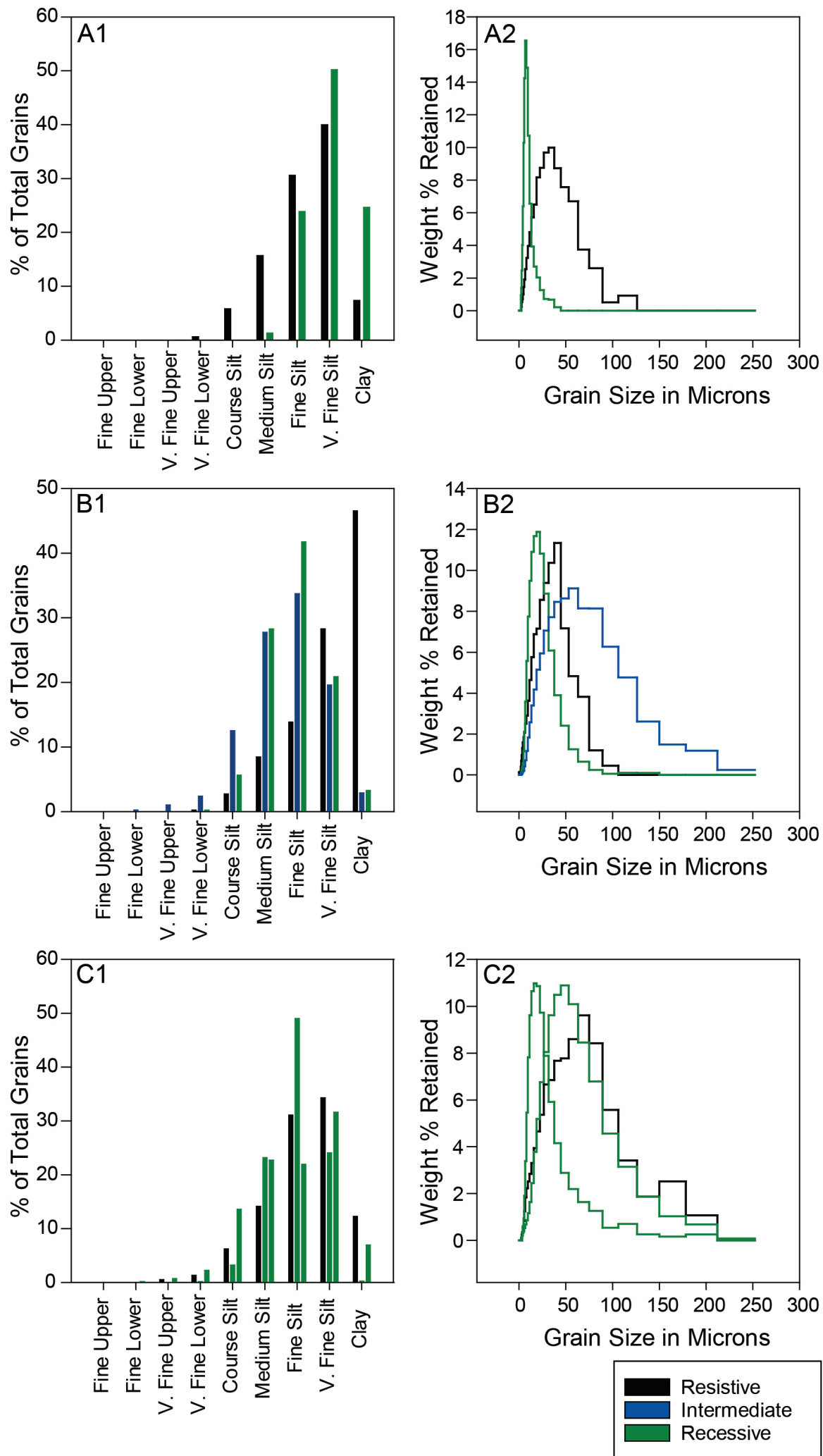
Bedsets of the stacked recessive lithofacies association are fining-upward successions with the prevalence of pedogenic features increasing upward. Some beds at the base of each story have original deposition structures, mostly soft-sediment deformation, preserved (Fig. 6C, no. 1). Beds are defined by differing sizes and shapes of peds, curving cracking patterns (Fig. 6C, no.2), and surfaces defined by the transition from coarser silty beds to muddy beds.

\section{Interpretations}

The stacked recessive association comprises composite paleosols developed on either lacustrine or fluvial overbank deposits in which the sedimentation rate was significantly less than the rate of pedogenesis (Fig. 21C). Sediment continued to be delivered to the system by either unconfined overland flow or wind, resulting in aggregation. However, pedogenic processes overprinted the original sedimentary structures. Horizontal beds were soil horizons, perhaps many generations of soils overprinted over one another. These lithofacies also formed where lacustrine deposits of mudstone and gypsum accumulated (Fig. 21D), often overprinted with paleosol features. The recessive lithofacies association is volumetrically significant but poorly exposed.

\section{DISCUSSION}

\section{A Continental Alluvial Plain Environment of Deposition for the Red Peak Formation}

The Red Peak Formation is a fine-grained aggregational depositional system resulting in the deposition of laterally continuous units. Most of the Red Peak Formation sediment was transported and deposited by a combination of wind and unconfined overland water flow. Unconfined overland flow resulted in large sand sheets or down-stream accreting braided channel systems propagating across a low-relief distal alluvial fan. Some saline lakes, likely short-lived and shallow, precipitated gypsum and perhaps authigenic silicates. Sediment was subsequently altered through pedogenic processes and early diagenesis. Later burial, compaction, and exhumation obscured some original sedimentary features while enhancing pedogenic textures.

The Red Peak Formation's silt deposits formed tabular siltstone bodies of indeterminate spatial extent, extending more than tens of kilometers laterally. Most of these tabular siltstones lack clear channel forms but have extensive internal surfaces and abundant current cross-stratification. This unusual "silt sheet" sediment body morphology requires an explanation; it has internal structures indicative of fluvial system but an overall system architecture that lacks the defined channel morphologies diagnostic of either branded and anastomosing or meandering fluvial 
systems. Thin sand or siltstone sheets with a great aerial extent are well known from modern and ancient eolian, ephemeral lacustrine, and loess systems, but rarely constitute large volumetric proportions of the sediment depositional framework (Kocurek and Nielson, 1986; Langford, 2000; Hall et al., 2010).

The morphological features of tabular siltstones in the Red Peak Formation are consistent with rapid deposition by unconfined overland water flow or wind reworking of sediment over a large geographic area. All deposition elements are consistent with deposition in a distributive fluvial system forming a "megafan" in a low-relief internally drained basin (Weissmann et al., 2010; Hartley et al., 2010). Sediment filled the available accommodation space, as it laterally accreted across the landscape without major incision (Fig. 21). Where sediment supply was high, or floods were frequent, channelized flow occurred. In such areas of high-frequency flooding with high net sediment load, the deposition would have made large, shallow braided river systems with migrating channels welded together to form tabular sheets (Fig. 21A). Where sedimentation was low or infrequent, the soil had time to form (Fig. 21B). The wind caused further migration of the silt sheets, with fine-grained eolian sediments with entrapment by soil moisture or sparse vegetation. The deposition of more fine sediment made available more grains for translocation within the soil profile. Provided enough time and stability, soil profiles merged to form thick successions of recessive beds with ubiquitous soil features. Sediment morphology and micro-morphology are consistent with well-developed soils, including well-formed iron-rich granular microstructures. Soils developed on all surfaces exposed subaerially, with the extent of soil formation dependent on landscape stability. Well-developed soils were more likely to form quickly on fine-grained parent materials where the large total mineral surface area was available for reactions than on relatively coarser sediment (Dixon and Weed, 1989).

Fine-grained sediment also accumulated in lacustrine and lacustrine adjacent environments (Fig. 21D). Lakes of saline or hypersaline water rich in $\mathrm{Ca}$ and $\mathrm{SO}_{4}$ deposited fine-grained mud and bedded gypsum. Laminated mudstone can accumulate from the settling of particles washed into the system by floods and winds or by the precipitation of authigenic minerals from saline waters. Bedded gypsum can precipitate from $\mathrm{Ca}-\mathrm{SO}_{4}$-rich surface waters, mainly by evapoconcentration. Large mudflats and sandflats are commonly adjacent to saline lakes. Most lacustrine deposits in the Red Peak Formation are obscured by pedogenic overprinting or outcrop weathering. The gypsum-rich recessive unit exposed from Bighorn Lake to Greybull suggests a lake or a series of lakes covered an area at least $40 \mathrm{~km}$ in diameter (Fig. 5). A more detailed investigation of the well-exposed Red Peak Formation outcrops along the flank of the Bighorn Basin (Fig. 1) is needed to constrain lacustrine environments of deposition further. 
Fig. 16: Example photomicrographs from angular to sub-angular siltstones at Alcova Reservoir (A and $B)$ and Willow Hill (C and $D)$ showing early soil features, all in plane-polarized transmitted light. (A) Weakly-formed (no. 1) and well-formed (no. 2) granular micro-aggregates in muddy siltstone. (B) Blobby iron-rich cement (no. 1) in laminated siltstone. Micro-deformation of lamination surface (no. 2-3). (C) Root features (point 1) disrupting sediment, sub-vertical cracking with a muddy matrix (no. 2), burrows filled with slightly coarser sediment (no. 3), and intraformational ripups (no. 4). (D) Adhesive meniscus burrow (no. 1), root-bioturbation (no. 2), sediment-filled burrow (no. 3), and iron cement (no. 4).
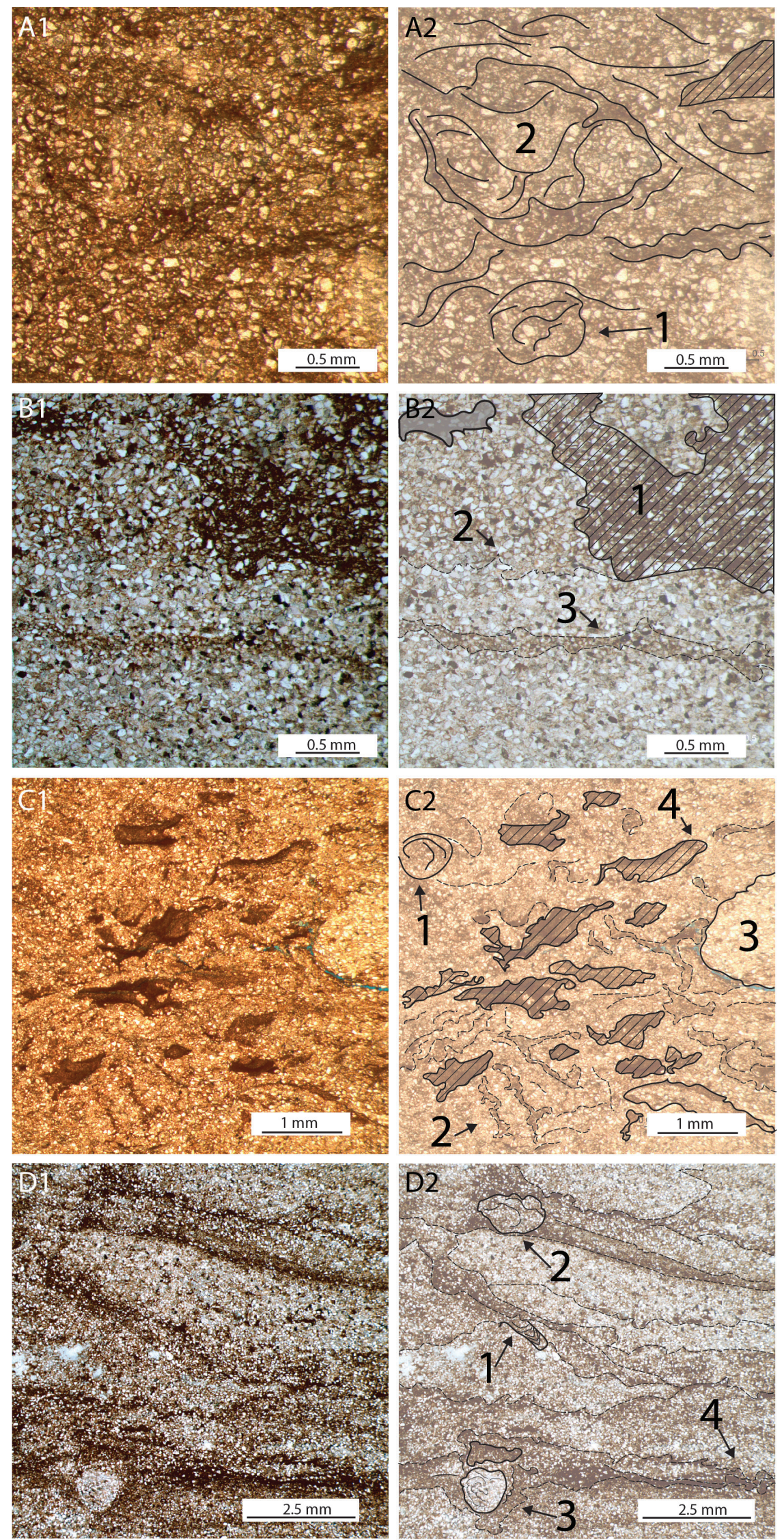

105 


\section{The Red Peak Formation is not a Marine Red Bed}

The Red Peak Formation has no evidence of marine deposition; it has no marine body fossils or trace fossils and no unambiguous marine, lagoon, or sabkha sedimentary structures. Furthermore, the presence of gypsum and siliciclastics without notable carbonates strongly suggests that neither seawater nor evaporated seawater was present in the depositional environment.

Red beds are known to form at the Earth's surface and have been considered diagnostic of continental environments (Tomlinson, 1916; Walker, 1967, 1968; Van Houten, 1973; Walker, 1974). The only notable example of red beds forming from an in-situ marine setting is the Upper Cretaceous oceanic red beds (CORBs) deposited during the Late Cretaceous and early Tertiary across a broad swath of the Tethys Sea (Hu et al., 2005). Red and reddish-pink shales and marls were deposited in oxygenated bottom water conditions across various depositional environments. CORBs are deep water pelagic to hemipelagic deposits consisting of abundant deep-water marine sedimentary structures. Red pelagic sediment is composed of up to $70 \%$ carbonate with open marine sedimentary structures, including complete Bouma sequences, slumps, and bioturbation, particularly from the Zoophycos ichnofacies (Wagreich and Krenmayr, 2005). Dating of the CORBs can be easily accomplished due to abundant well-preserved microfossil assemblages of both benthic and pelagic foraminifera (Hu et al., 2005; Wagreich and Krenmayr, 2005), with no in-situ oceanic red beds known to have been deposited between the cessation of BIF formation and the Late Cretaceous. The Red Peak Formation has none of those easily identified marine features.

The Red Peak Formation has abundant evidence for continental deposition. Paleosols, mud cracks, and rip-up clasts comprised of pedogenic mud aggregates are diagnostic of subaerially exposed environments. Fine-grained sediment, ripple cross-lamination, and wedge cross-bedding are consistent with eolian and unconfined overland flow deposition. All sedimentary structures, bedset geometries, lithofacies, lithofacies associations, and stacking patterns are consistent with deposition in continental alluvial and lacustrine environments. 


\section{A Distributive Alluvial System in a Large Closed Basin}

The Red Peak Formation is a fine-grained aggregational continental deposit with conspicuous yet unusual fluvial elements. Basin-filling aggregational fluvial and alluvial systems are a radial network of channels and associated deposits that radiate from when a river enters a basin (Weissmann et al., 2010). Unlike fluvial systems in degradational settings, distributive fluvial systems, and associated alluvial facies elements decrease flow depth and incision down-system, do not produce much erosion, and result in an upward convex lobate geometry of the overall system (Friend, 1977; Nichols and Fisher, 2007). As represented as lithofacies associations, the Red Peak Formation's sediment stacking patterns conform to medial and distal facies of distributed fluvial systems.

The agglomerated lithofacies association are stories of channel deposits without fine-grained overbank deposits. The lack of mud results as channels either laterally migrate across the landscape, re-working adjacent flood plain deposits (Davidson et al., 2013). It is also possible these low-erosion channels provide a bypass mechanism for fine-grain sediment with frequent high-velocity flows that only deposit fines when they are converted to overland unconfined flow down-system. These proximal channels will accumulate sufficient sediment to prevent pedogenesis, perhaps accumulating $7 \mathrm{~m}$ to $10 \mathrm{~m}$ of sediment in several stories before avulsing and causing a lobe switching to another part of the system. Because the system is aggregational and migrating across as landscape, the traditional fluvial channel deposits will be missing, resulting in a more laterally continuous deposit. However, diagnostic sedimentary features will be internal erosion and lateral or down-dip accretion from the migration of bar forms in the stream.

The alternating facies association is deposited in the alluvial distributive system's distal zones where channelization is rare, and overland flow produces sheets of relatively coarse-grained sediment. Sheets of sediment have sharp or locally erosive bases and are found in packages of units many meters thick (Fisher et al., 2007). Thickly bedded finer-grained units between sheets have some paleosol development. This environment is a terminal splay deposit at the edge of the alluvial-fan and into the alluvial plain. For this distinctive morphology to develop, sediment delivery must exceed the rate of basin floor subsidence. If the basin flor subsidence rate exceeds sediment delivery, the system will become degradational, and an incised valley or traditional alluvial fan would form. The higher the sediment supply, the quicker the accommodation space would be filled, and the more likely channel evulsion and lobe switching would occur. 

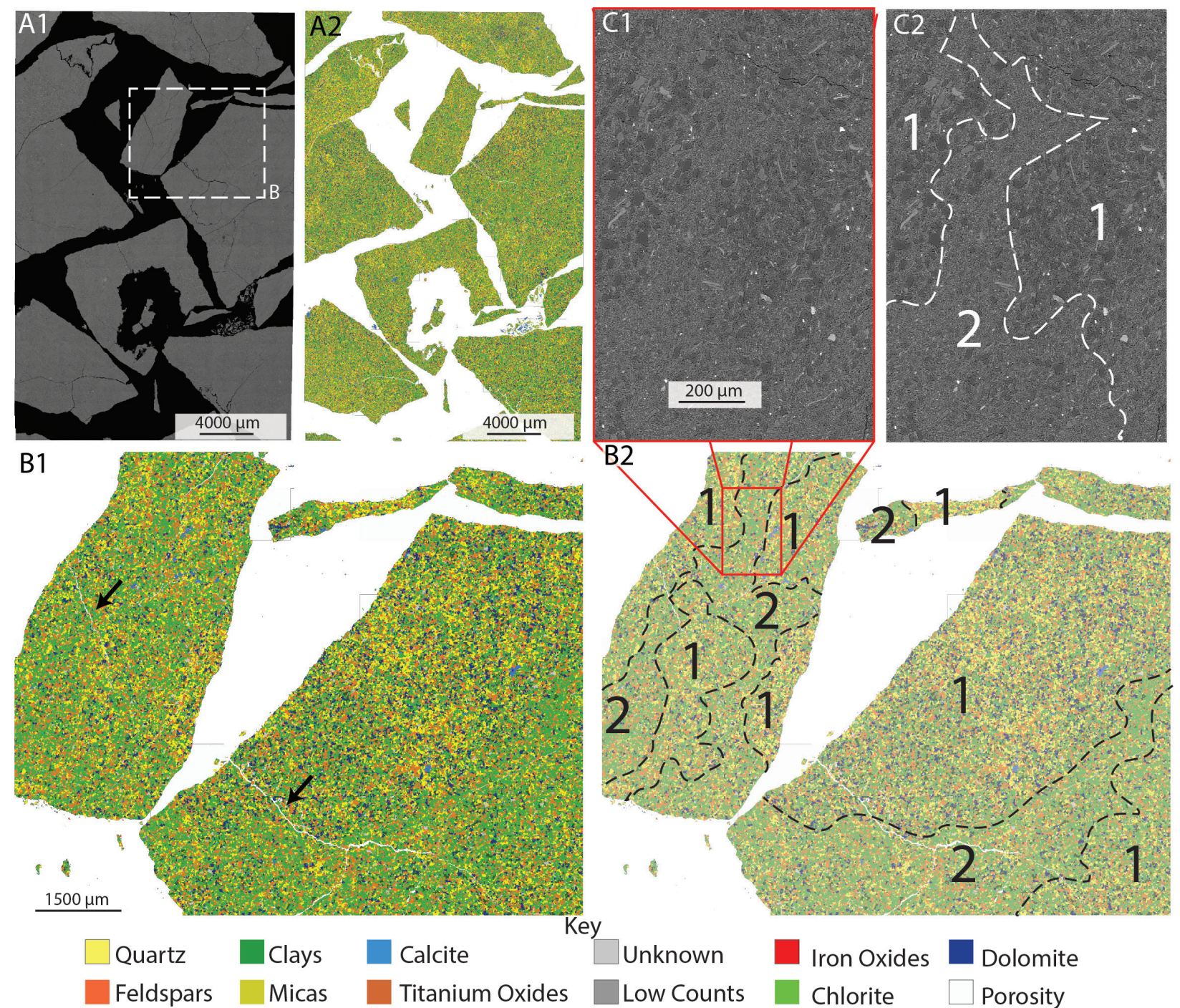

ey
Feldspars
Low Counts
Chlorite
$\square$ Porosity

Unknown

Iron Oxides

Dolomite

Fig. 17: Example SEM automated mineralogy map from resistant lithofacies. Intraformational rip-ups (C, no. 1), likely liberated pedogenic aggregates, contribute a significant amount of clay. The rock is compacted siltstone (no. 2), an iron-rich clay matrix with pore-filling calcite and dolomite cement. 
Fig. 18: Example of SEM automated mineralogy map of recessive lithofacies. Particles are randomly oriented peds collected in grab samples directly from the outcrop and made into polished thick-section grain mounts. All particles have pedogenic micro-granular aggregates (B2; C2) with zones of course (no. 1) and fine (no. 2) granules where circumgranular cracks bound roughly circular areas of either coarse or fine sediment. When circumgranular cracks join, it defines the particle boundaries and thus the texture of the outcrop.
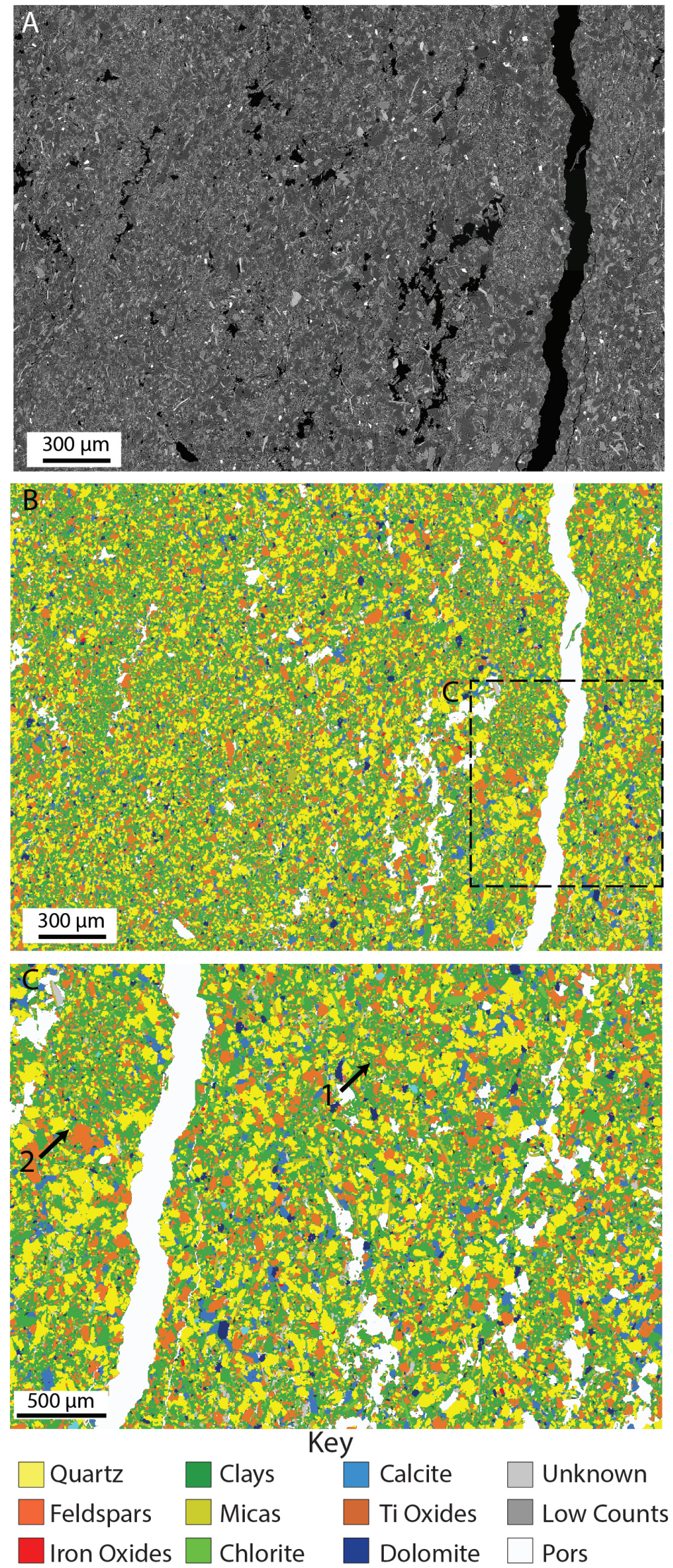
The recessive lithofacies association occurs in abandoned river tracks where paleosols can develop thick horizons, where the deposition is far enough away from the end of channelization that course silt and sand cannot reach it, and where lakes develop. Shallow lakes are common in distributive fluvial systems. Distributive fluvial systems only occur in underfilled basins in arid climates (Weissmann et al., 2010; Hartley et al., 2010; Davidson et al., 2013). The distributive fluvial system delivers water to the alluvial plane in a closed or underfilled basin, often the location of ephemeral lakes and saline playas where the overland flow from distal fans can result sandflats, mudflats, and periodic flooding (Eugster and Hardie, 1978). Changes in climate that increase the water supply or decrease evaporation can result in basin-center prerenal lakes (Nichols and Fisher, 2007; Fisher and Nichols, 2013).

Loess deposition must be considered a possibility for the tabular siltstone beds. Similar to the alternating lithofacies assemblages, loess beds can be traced laterally for hundreds of square kilometers and are separated by paleosols (Smalley, 1966). Loess is wind-blown fine-grained sediment trapped by vegetation and accumulates in horizontal beds with a characteristic lack of sedimentary structures (Smalley, 1966; Tsoar and Pye, 1987; Sun, 2002). Unlike loess, the Red Peak Formation has erosional bases, soft-sediment deformation, widespread current ripple cross laminations, and cross-bedding, all inconsistent with loess deposition. However, the grain size and mineralogy are consistent with modern and ancient loess (Soreghan et al., 2008b; Licht et al., 2016; Yang et al., 2016). It is possible that widespread wind-driven deposition of silt and smaller sized sediment contributed large volumes of fine sediment. Subsequent reworking by wind and unconfined flow would result in similar sedimentary features to the alternating lithofacies assemblage and explain silt-sized sediment's predominance.

The preservation potential for distributive fluvial and associated alluvial systems is high. Fluvial/ alluvial lobe switching will occur and fill all available accommodation space, meaning a single point source may provide sediment across a large landscape. Underfilled basins will fill to the spill-point, accumulating sediment more than the original accommodation space due to viscoelastic relaxation or continued tectonic substance (Beaumont, 1978; Bohacs et al., 2000; Weissmann et al., 2010; Fisher and Nichols, 2013). The extensiveness of the laterally continuous units of the Red Peak Formation and the uniformly fine-grained sediment may result in being a distal part of a large alluvial fan with nearly unlimited space for lobe switching. 

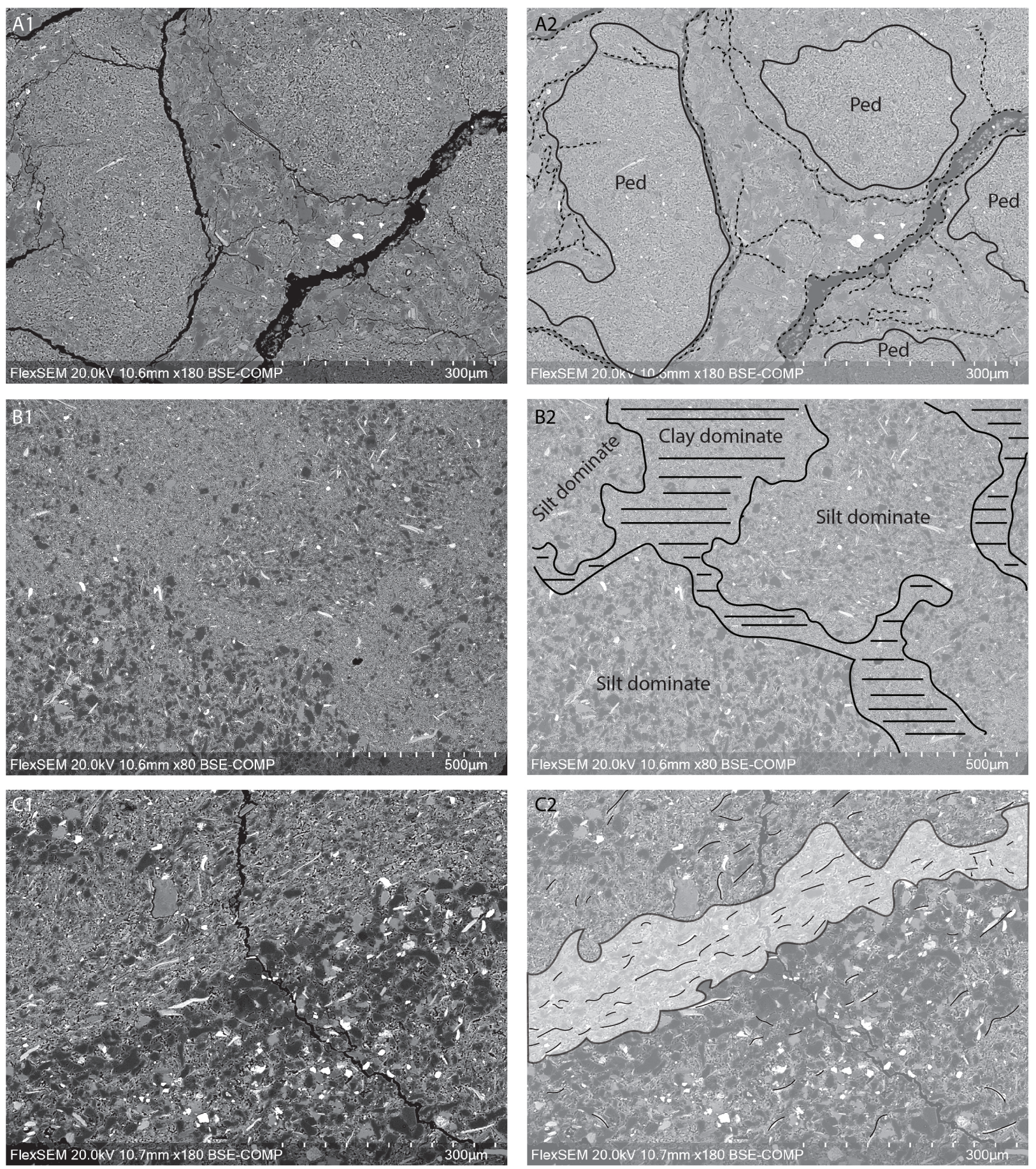

Fig. 19: Details of in-situ pedogenic micro-aggerates from recessive lithofacies. Pedogenic aggerates can form as either mud-cored aggerates (A) or silt-cored aggerates (B). Aggerate boundaries $(C)$ are defined by abrupt grain size changes, aligned micas and clays, and circumgranular cracks. 

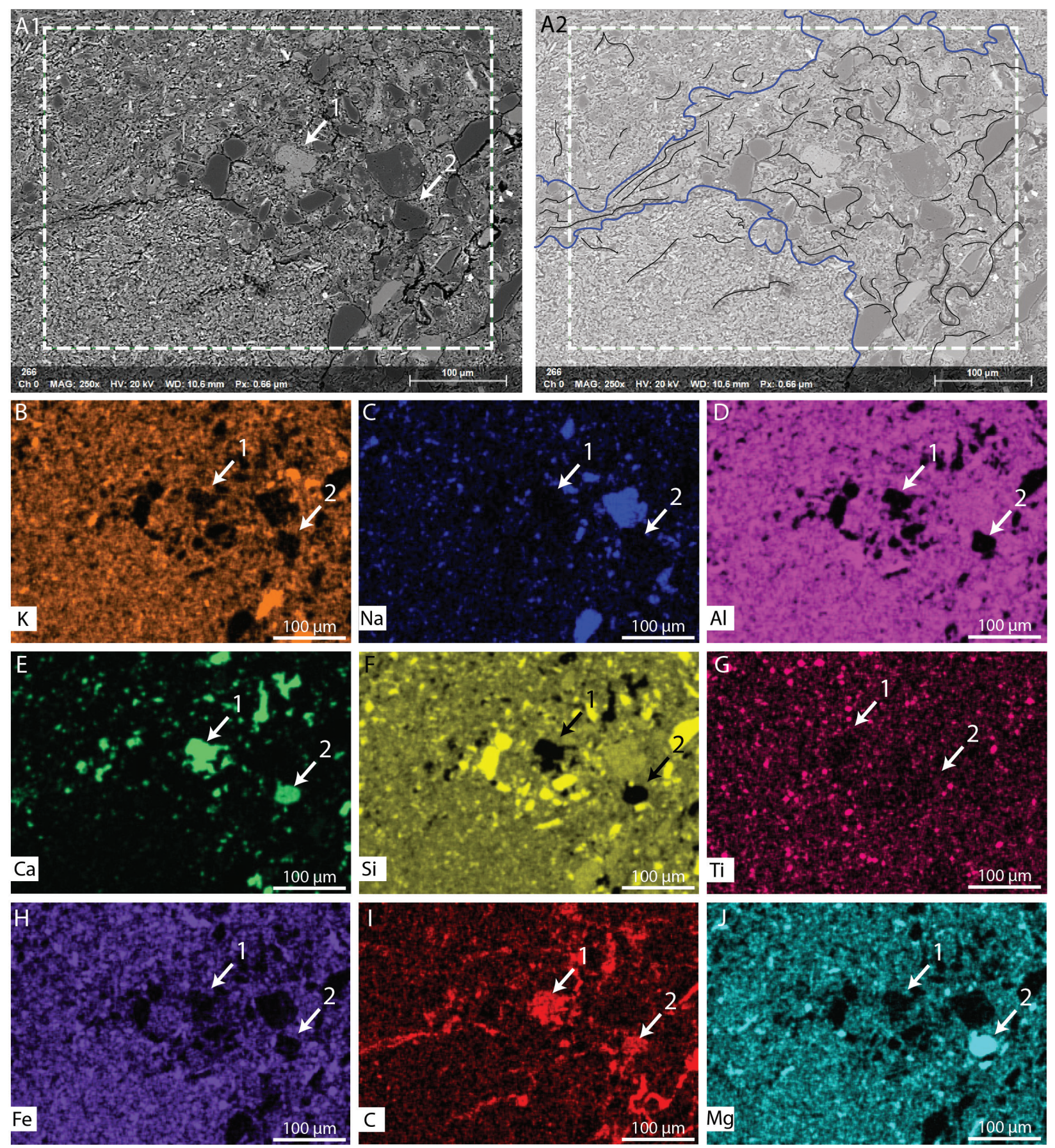

Fig. 20: Details (A) and elemental maps (B to J) across the mud-rich pedogenic aggerate boundary (A2, blue line). Pedogenic mud aggerates, like all visible matrix, is comprised of aluminum $(D)$, potassium $(B)$, and iron-rich $(H)$ clay with some titanium-rich clay particles $(G)$ and small stranded quartz grains $(F)$. The area between the pedogenic aggregates has larger grains of quartz and feldspar, poor-filling calcite (no. 1), and dolomite cement (no. 2, note Mg in map $J)$. Circumgranular cracks are highlighted in the carbon map (I), where thicker carbon coating filled cracks. 


\section{Pedogenic Aggregates and Paleosols}

Pedogenic mud aggregates are sand-size to gravel-sized particles formed from wetting and drying or heating and cooling in soils rich in swelling clays (Muller et al., 2004). In both modern and ancient dryland systems, pedogenic aggregates are an important feature where clay-rich alluvium aggregates join in a pervasive texture in the remnant paleosol horizon and can be transported, deposited, and preserved as bedload in fluvial systems (Rust and Nanson, 1989; Gierlowski Kordesch and Gibling, 2012). In the Red Peak Formation, pedogenic aggregates are present as in-situ granules and as transported grains in siltstones. Roughly spherical or elliptical aggregates in the recessive facies are similar in composition, with rough surfaces often coated in micro-laminated clays, indicating in-situ formation (Muller et al., 2004).

Pedogenic aggregates in the outcrop, commonly called peds, are a foundational unit for the classification of modern and ancient soils (Retallack, 1998b). Peds are soil particles separated by pores or voids. Peds form through a series of linked processes in soils with more than $15 \%$ clay content (Kühn et al., 2018; Marcelino et al., 2018). These processes include (1) in-situ weathering of rock-forming minerals to form clay minerals; (2) the shrinking and swelling of soil B horizon through wetting and drying; and (3) illuviation and translocation of silt into the resulting pore space, coating aggregates (Kühn et al., 2018). Peds can range from $\sim 1 \mathrm{~mm}$ to $\sim 10 \mathrm{~cm}$ in diameter and be classified as blocky, columnar, prismatic, or wedge-shaped. The term "granular" can be used to describe peds and aggregates less than $10 \mathrm{~mm}$ in diameter (Marcelino et al., 2018), and the aggregates and peds can be used interchangeably for granular textures. Pedogenic mud aggregates, formed in vertisols and transported as bedload in dryland river systems, has upended the perception that mud can only be transported as suspended load and deposited through suspension (Gierlowski-Kordesch and Rust, 1994). Mud drapes and muddy lamina are not deposited only by high-velocity flow, and mud aggregates may form sedimentary structures previously thought only possible for coarse silt or sand (Rust and Nanson, 1989; Muller et al., 2004; Gierlowski Kordesch and Gibling, 2012).

In-situ pedogenic aggregates are diagnostic of soils, but they are difficult to recognize in thin sections and often easily destroyed by compaction. However, this study has demonstrated that pedogenic mud aggregates can be readily identified using SEM images and automated mineralogy, even in sediments for which thin sections are difficult to make. In-situ pedogenic aggregates can be easily separated from transported aggregates by examining the boundaries between aggregates (Rust and Nanson, 1989; Muller et al., 2004). 
Attempts were made to classify the soils using Retallack's terminology, but the Red Peak Formation's paleosols were resistant to this classification. The Red Peak Formation's paleosols have a well-developed granular texture with less than $10 \%$ weatherable materials, consistent with oxisols (Soil Survey Staff, 1994). Blocky peds (Fig. 8) in outcrop and granular microstructure (Fig. $17,19,20)$ that are consistent with oxisol soil morphology (Buol and Eswaran, 1999; Marcelino et al., 2018). They have no clear salic, natric, cambic, calcic, petrocalcic, gypsic, or argillic horizons, ruling out aridsols (Soil Survey Staff, 1994). The paleosols of the Red Peak Formation could have some vertisols but are mostly inconsistent with vertosol features. Columnar peds (Fig. 8D) and cutains (Fig. 8E, 16A) are rarely well developed. The well-developed granular texture suggests that oxisols may have formed with a well-developed microstructure but were not stable long enough to form other features such as accumulations of carbonate. However, the soils still had many unaltered micas and feldspars, inconsistent with the traditional oxisols model. They also did not have a well-developed horizonation in the outcrop. This "oxisol problem" requires further investigation, including resolving the climatic and environmental conditions that could result in red beds.

The practice of assigning a modern soil name to an ancient paleosol brings significant confusion concerning climate and the environment. In modern environments, oxisols are highly weathered soils that form in tropical latitudes where abundant moisture and heat promote the breakdown of rock-forming minerals on highly stable (e.g., unglaciated) landscapes. During the late Permian and Early Triassic, aridity was widespread (Dickins, 1993; Loope et al., 2004; Huey and Ward, 2005). The Red Peak Formation's sedimentary features are consistent with this, indicating an arid environment with little vegetation, ephemeral unconfined overland flow, and high evaporation. However, abundant soft-sediment deformation and scour surfaces indicate the surface or near-surface water may have been abundant at times. Saline groundwater may have been close to the sediment-air interface, where it was wicked to the surface by evapoconcentration to form ephemeral saline crusts that also trapped wind-blown sediment (Smoot and Castens-Seidell, 1994). The well-developed granular textures in the soils could reflect extremes of wet-dry or hot-cold cyclicity rather than long landscape stability time or a high degree of weather. It is also possible that the continuous contribution of unweathered fine-grained immature sediment and subsequent alluviation confuses the issue. Further consideration must be made for surface recycling of sediment that is often redistributed by overland flow. 


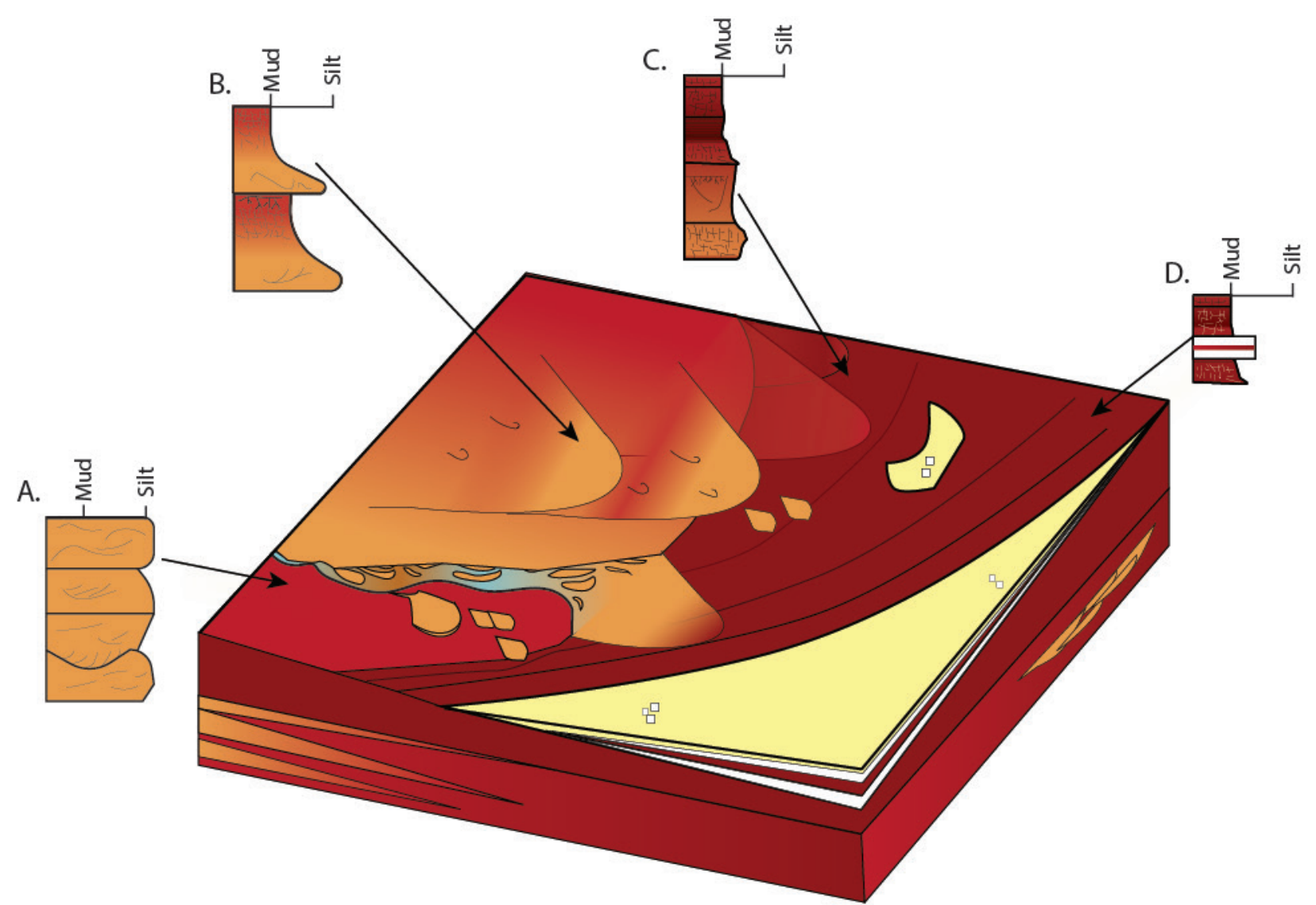

Fig. 21: Generalized model of Red Peak sedimentation. Detail showing part of the alluvial system with active sedimentation. (A) Large nearly-unconfined distributive fluvial systems migrating across a low-relief landscape or high-frequency unconfined flooding event result in stacked bedsets of resistant siltstone. (B) Periodic unconfined flooding and consistent wind move tabular sheets of silt over large areas. Periods of quiescence are long enough for pedogenic processes to develop thin soils. (C) Small ephemeral lakes and mudflats with unconfined flooding and wind moving silt sheets across the landscape. Periods of environmental stability between silt sheet migration are long enough for thick soils to form. (D) Large (30+ kilometers) saline lakes and mudflats with rare tabular silt sheets introduced by flooding events and wind. Evapoconcentration and desiccation of lakes are common. The aspect ratios and sediment body geometries of silt or sand bodies are unconstrained by vegetation, and the wind is a major driver of sediment movement. 
The classification of paleosols using modern soil orders may cause more confusion than is necessary. Red beds may be particularly difficult to classify, representing formation in a combination of environmental and climatic conditions that are not easily studied on Earth today. Red beds may be a new order of soils if studied by a time-traveling soil scientist. Assigning a soil order seems particularly problematic, as all modern soil order impart specific implications for water availability and climate.

We suggest an approach beyond this dissertation's scope that attempts to tie specific soil features to physical and chemical origin informed by modern soils. For example, consider the weak blocky ped texture profile and a well-developed granular microstructure of the Red Peak Formation. This granular structure is comprised of clusters of cohesive aggregates with iron-oxide rich clays and silt. Clusters of silt and clay are either fully separated, "welded" together or separated by fine silt sediment filling spaces. The texture is consistent with oxisols' (formally classified as laterites, latosols, and various lateritic soils) (Buol and Eswaran, 1999; Marcelino et al., 2018). Oxisols may have up to $80 \%$ clay minerals by volume and consist of over $95 \%$ or clay grain sizes particle (Buol and Eswaran, 1999). The defying mineral assemblages are disordered kaolinite with sesquioxides, leading to a similar persistent, granular microstructure (Buol and Eswaran, 1999). The Red Peak Formation has more weatherable silt than modern oxisols. However, it is reasable to conclude the formation of aggregates likely developed through in-situ weathering and transformation of primary rock-formatting minerals to disordered kaolinite with sesquioxides. The granular texture can be attributed to minor swelling associated with wet-dry cycles, the formation of poorly-developed but cohesive cutans, clay coatings that around peds or voids (Brewer, 1960), and friable minerals (Retallack, 1998b; Buol and Eswaran, 1999; Marcelino et al., 2018). The pedogenic mud aggregates may have been protected by the stable and cohesive nature of kaolinite with sesquioxides that may preserve aggregates during bedload transport. Thus, the granular texture and the pedogenic mud aggregates suggest an arid climate with intensive surface weathering without evoking the oxisol classification. Moving beyond classification and into the world of process may free paleopedology for greater impacts on paleoclimate and environment.

The end-Permian and Triassic environmental crisis created ecosystems across Pangea's wideswaths more extreme than exists on Earth today, with high-heat, saline, and acidic near-surface brine and a biotic world reduced to a few hardy animals, plants, and extremophiles. Regional examples of the extreme lake and mudflat environments characterized by acid ( $\mathrm{pH}$ as low as -1) 
brine with complex chemistries under hot, arid, windy conditions have been reported from the Permian Nippewalla Group of Kansas, the Permian Opeche Shale of North and South Dakota and the Triassic Mercia Mudstone Group of Northern Ireland (Benison et al., 1998; Benison and Goldstein, 2000, 2001; Benison, 2006; Hopkins, 2011; Zambito and Benison, 2013; Andeskie et al., 2018). The best known modern analogs for such extreme environments are the acid saline lacustrine and Western Australia groundwater systems (Benison et al., 2007). These modern acid brine environments precipitate halite and gypsum in siliciclastic host sediments. Direct precipitation of iron oxides and aluminosilicates by lakes and groundwaters and enhanced weathering of regolith occurs in these Western Australian environments (Bowen et al., 2008, 2013; Story et al., 2010). If such extreme environments were present at the Red Peak Formation deposition, this could explain the development of iron-rich granular textures and the lack of soil carbonates. Halite may have precipitated in the Red Peak environments but been dissolved later, as documented for the Permian Nippewalla Group of Kansas (Benison et al., 2015). However, the Red Peak has no preserved halite, and thus direct evidence of acid saline brines is not possible. Regardless, the association of gypsum/anhydrite and Fe-bearing silicates, with paucity or absence of carbonates, have been used as criteria for acid saline depositional environments (Benison and Goldstein, 2002).

\section{Implications for Triassic Climate and Paleography}

Southcentral Wyoming was positioned in the northern tropics on the supercontinent Pangea during the late Paleozoic and early Mesozoic (Blakey and Ranney, 2008), a time of drastic environmental change. Around the time of the coalescing of Pangea in the late-Paleozoic Era, glaciation dominated climatic variation (Isbell et al., 2003; Fielding et al., 2008), perhaps reaching low-latitudes (Soreghan et al., 2014). It has been hypothesized that large accumulations of loess and eolian silt in the Permian can be attributed to the convergence of increasing aridity with tectonic uplift mobilization of physically mature, yet chemically immature, sediment (Soreghan et al., 2008a). Throughout the Permian and into the Early Triassic Period, there was increasing aridity, air temperatures, and extremes in surface water and groundwater geochemistry (Tabor, 2013, and references there).

A growing body of evidence suggests that equatorial and mid-latitudes of Pangea, including North Dakota, Kansas, Oklahoma, and Northern Ireland, were dominated by a mosaic of an internally drained acid and neutral saline lakes, surrounded by red bed mudflats, paleosols, and uncommon dunes and sand sheets (Benison and Goldstein, 2001; DiFrisco et al., 2013; Zambito 
and Benison, 2013; Giles et al., 2013; Benison et al., 2014). Refining the timing of deposition of the Red Peak Formation further than middle Permian - Middle Triassic is not feasible, and thus it cannot be determined how much Red Peak deposition overlaps temporally with the extreme environments to the east. However, lithofacies assemblages are consistent with the up-gradient expression of a continent-wide system of low-relief, interrelated extreme environments. The Red Peak Formation's large silt sheets introduce a new component to this system not described before and indicate high sediment supply, unconfined overland fluid flow, and high winds.

\section{CONCLUSIONS}

The sedimentology, micromorphology, and mineralogy data presented in this study suggest the Red Peak Formation of Wyoming was deposited in a continental environment (distributive fluvial and associated alluvial and lacustrine), not an open or marginal marine environment. Lithofacies show no evidence of marine fossils or trace fossils, or sabkha features, or micromorphology consistent with a deposition's marine environment.

Deposition of the Red Peak Formation occurred in a series of interrelated environments on an extensive low-relief distal alluvial fan and alluvial plain, predominately from unconfined overland flow. Sediment transport occurred as both subaqueous and eolian transport. Saline ephemeral lakes and mudflats were important constituents on the landscape. Soil morphology or micromorphology overprints most units. Soil features further support deposition in an arid continental environment. Paleosols of the Red Peak Formation predominately have features consistent with deposition in arid environments and may indicate exceptionally long landscape stability, frequent recycling of weathered sediment, continuous input of chemically immature silt, increased weathering, or some combination. The well-developed granular texture of soils results in the formation of pedogenic mud aggregates found in-situ in recessive lithofacies and transported in the Red Peak Formation's resistant lithofacies.

The Red Peak Formation environments are consistent with the interpretation of Pangea's interior's geography in the late Permian and Early Triassic dominated by extreme environments and internally drained basins. Low relief continental environments dominated by acidic lakes have been reported from Kansas, North Dakota (Benison and Goldstein, 2001), and Oklahoma (Giles et al., 2013). A global environmental perturbation is indicated with evidence of extensive continental acid saline lakes from Ireland (Andeskie et al., 2018). A global reexamination of the Permian-Triassic red beds is indicated to understand the causes and consequences of this "global weirding" of environments and geochemistry. 


\section{REFERENCES}

Andeskie, A.S., Benison, K.C., Eichenlaub, L.A., and Raine, R., 2018, Acid-saline-lake sys tems of the Triassic Mercia Mudstone Group, County Antrim, Northern Ireland: Jour nal of Sedimentary Research, v. 88, p. 385-398, doi:10.2110/jsr.2018.14.

Beaumont, C., 1978, The evolution of sedimentary basins on a viscoelastic lithosphere: theory and examples: Geophysical Journal International, v. 55, p. 471-497, doi:10.1111/j.1365246X.1978.tb04283.x.

Benison, K.C., 2006, A Martian analog in Kansas: comparing Martian strata with Permian acid saline lake deposits: Geology, v. 34, p. 385-388, doi:10.1130/G22176.1.

Benison, K.C., Bowen, B.B., Oboh-Ikuenobe, F.E., Jagniecki, E.A., LaClair, D.A., Story, S.L., Mormile, M.R., and Hong, B.-Y., 2007, Sedimentology of acid saline lakes in southern Western Australia: newly described processes and products of an extreme environment: Journal of Sedimentary Research, v. 77, p. 366-388, doi:10.2110/jsr.2007.038.

Benison, K.C., and Goldstein, H.R., 2001, Evaporites and siliciclastics of the Permian Nippewalla Group of Kansas, USA: a case for non-marine deposition in saline lakes and saline pans: Sedimentology, v. 48, p. 165-188, doi:https://doi.org/10.1046/j.13653091.2001.00362.x.

Benison, K.C., and Goldstein, R.H., 2000, Sedimentology of ancient saline pans: an example from the Permian Opeche Shale, Williston Basin, North Dakota, U.S.A.: Journal of Sedimentary Research, v. 70, p. 159-169, doi:10.1306/2dc40907-0e47-11d7$8643000102 \mathrm{c} 1865 \mathrm{~d}$.

Benison, K.C., Goldstein, R.H., Wopenka, B., Burruss, R.C., and Pasteris, J.D., 1998, Extremely acid Permian lakes and ground waters in North America: Nature, v. 392, p. 911-914, doi:10.1038/31917.

Benison, K.C., Zambito, J.J., and Knapp, J., 2015, contrasting siliciclastic-evaporite strata in subsurface and outcrop: an example from the Permian Nippewalla Group of Kansas, U.S.A: Journal of Sedimentary Research, v. 85, p. 626-645, doi:10.2110/jsr.2015.43.

Benison, K.C., Zambito, J.J., Soreghan, G.S., Soreghan, M.J., Foster, T.M., Kane, M.J., Dubois, M.K., Watney, W.L., and Tollefson, J., 2014, Permian red beds and evaporites of the Amoco Rebecca K. Bounds core, Greeley County, Kansas: implications for science and industry, in Kansas Geological Survey and Kansas Geological Society ed., Mid-continent core workshop: from source to reservoir to seal. Mid-Continent Section American Associ- 
ation of Petroleum Geologists, Kansas Geological Survey, Wichita, Kansas, p. 9-14.

Blakey, R.C., and Gubitosa, R., 1984, Controls of sandstone body geometry and architecture in the Chinle Formation (Upper Triassic), Colorado Plateau: Sedimentary Geology, v. 38, p. 51-86, doi:10.1016/0037-0738(84)90074-5.

Blakey, R.C., and Ranney, W., 2008, Ancient Landscapes of the Colorado Plateau: Grand Canyon Assn, 176 p.

Bohacs, K.M., Carroll, A.R., Neal, J.E., and Mankiewicz, P.J., 2000, Lake-basin type, source potential, and hydrocarbon character: an integrated sequence-stratigraphic-geochemical framework: Lake basins through space and time: AAPG Studies in Geology, v. 46, p. 3-34.

Bowen, B.B., Benison, K.C., Oboh-Ikuenobe, F.E., Story, S., and Mormile, M.R., 2008, Active hematite concretion formation in modern acid saline lake sediments, Lake Brown, Western Australia: Earth and Planetary Science Letters, v. 268, p. 52-63, doi:https://doi. org/10.1016/j.epsl.2007.12.023.

Bowen, B.B., Story, S., Oboh-Ikuenobe, F., and Benison, K.C., 2013, Differences in regolith weathering history at an acid and neutral saline lake on the Archean Yilgarn Craton and implications for acid brine evolution: Chemical Geology, v. 356, p. 126-140, doi:10.1016/j.chemgeo.2013.08.005.

Boyd, D.W., and Loope, D.B., 1984, Probable vertebrate origin for certain sole marks in Triassic red beds of Wyoming: Journal of Paleontology, v. 58, p. 467-476, doi:10.2307/1304795.

Boyd, D.W., and Maughan, E.K., 1972, Permian-Triassic Boundary in the Middle Rocky Mountains: Bulletin of Canadian Petroleum Geology, v. 20, p. 676-699.

Branson, E.B., 1927, Triassic-Jurassic "red beds" of the Rocky Mountain region: The Journal of Geology, v. 35, p. 607-630, doi:10.2307/30063032.

Branson, E.B., 1947, Triassic (Chugwater) footprints from Wyoming: Journal of Paleontology, v. 21, p. 588-590, doi:10.2307/1299240.

Branson, E.B., 1915, Origin of the red beds of western Wyoming: Geological Society of America Bulletin, v. 26, p. 217-230, doi:10.1130/gsab-26-217.

Brewer, R., 1960, Cutans: their definition, recognition, and interpretation: Journal of Soil Science, v. 11, p. 280-292, doi:10.1111/j.1365-2389.1960.tb01085.x. 
Buol, S.W., and Eswaran, H., 1999, Oxisols: Advances in Agronomy, v. 68, p. 151-195, doi:10.1016/S0065-2113(08)60845-7.

Burk, C.A., 1953, Electric Log Correlation of the Triassic Rocks of Southeastern Wyoming: in Laramie Basin, Wyoming, and North Park, Colorado: 8th Annual Field Conference Guidebook, Wyoming Geological Association, p. 29-33.

Calvo, J.P., Blanc-Valleron, M.M., Rodríguez-Arandía, J.P., Rouchy, J.M., and Sanz, M.E., 2009, Authigenic clay minerals in continental evaporitic environments: in Thiry, M., Simon-Coinçon, R., eds., Palaeoweathering, Palaeosurfaces and Related Continental Deposits, Special Publications of the International Association of Sedimentologists, v. 27, p. 129-151, doi:10.1002/9781444304190.ch5.

Cant, D.J., and Walker, R.G., 1978, Fluvial processes and facies sequences in the sandy braided South Saskatchewan River, Canada: Sedimentology, v. 25, p. 625-648, doi:10.1111/j.1365-3091.1978.tb00323.x.

Cavaroc, V. V., and Flores, R.M., 1991, Red beds of the Triassic Chugwater Group, southwestern Powder River Basin, Wyoming: US Geological Survey Bulletin, v. 1917 E.

Colombera, L., Mountney, N.P., and McCaffrey, W.D., 2013, A quantitative approach to fluvial facies models: methods and example results: Sedimentology, v. 60, p. n/a-n/a, doi:10.1111/sed.12050.

DARTON, N.H., 1904, Comparison of the stratigraphy of the Black Hills, Bighorn Mountains, and Rocky Mountain Front Range: Geological Society of America Bulletin, v. 15, p. 379-448, doi:10.1130/GSAB-15-379.

Davidson, S.K., Hartley, A.J., Weissmann, G.S., Nichols, G.J., and Scuderi, L.A., 2013, Geomorphic elements on modern distributive fluvial systems: Geomorphology, v. 180-181, p. 82-95, doi:10.1016/j.geomorph.2012.09.008.

Deluca, J.L., and Eriksson, K.A., 1989, Controls on synchronous ephemeral- and perennial-river sedimentation in the middle sandstone member of the Triassic Chinle Formation, northeastern New Mexico, U.S.A.: Sedimentary Geology, v. 61, p. 155-175, doi:10.1016/0037-0738(89)90056-0.

Dickins, J.M., 1993, Climate of the Late Devonian to Triassic: Palaeogeography, Palaeoclimatology, Palaeoecology, v. 100, p. 89-94, doi:10.1016/0031-0182(93)90034-G.

DiFrisco, A.J., Knapp, J.P., and Benison, K.C., 2013, When is a limestone not a limestone?: calcite replacement of gypsum of the Permian Minnekahta limestone: Abstracts with 
Programs - Geological Society of America, v. 45, p. 818.

Dixon, J.B., and Weed, S.B. eds., 1989, Minerals in soil environments: Madison, WI, USA, Soil Science Society of America, SSSA Book Series, doi:10.2136/sssabookser1.2ed.

Doerr, S.H., Shakesby, R.A., Huang, P.M., Li, Y., and Sumner, M.E., 2011, Handbook of soil sciences: properties and processes, second edition: CRC Press, Cleveland, OH, 1447 p., doi:10.1016/B978-0-444-51269-7.50023-0.

Eugster, H.P., and Hardie, L.A., 1978, Saline Lakes, in Lakes, Springer New York, p. 237293, doi:10.1007/978-1-4757-1152-3_8.

Eugster, H.P., and Hardie, L.A., 1975, Sedimentation in an ancient playa-lake complex: the Wilkins Peak Member of the Green River Formation of Wyoming: Bulletin of the Geological Society of America, v. 86, p. 319-334, doi:10.1130/0016-7606(1975)86<319:SIAAPC $>2.0 . \mathrm{CO} ; 2$.

Fielding, C.R., 1986, Fluvial channel and overbank deposits from the Westphalian of the Durham coalfield, NE England: Sedimentology, v. 33, p. 119-140, doi:10.1111/j.1365-3091.1986.tb00748.x.

Fielding, C.R., 2006, Upper flow regime sheets, lenses and scour fills: Extending the range of architectural elements for fluvial sediment bodies: Sedimentary Geology, v. 190, p. 227-240, doi:10.1016/j.sedgeo.2006.05.009.

Fielding, C.R., Frank, T.D., and Isbell, J.L., 2008, Resolving the late Paleozoic ice age in time and space: Geological Society of America Special Papers, v. 441, 366 p.

Fisher, J.A., and Nichols, G.J., 2013, Interpreting the stratigraphic architecture of fluvial systems in internally drained basins: Journal of the Geological Society, v. 170, p. 57-65, doi:10.1144/jgs2011-134.

Fisher, J.A., Nichols, G.J., and Waltham, D.A., 2007, Unconfined flow deposits in distal sectors of fluvial distributary systems: Examples from the Miocene Luna and Huesca Systems, northern Spain: Sedimentary Geology, v. 195, p. 55-73, doi:10.1016/j.sedgeo.2006.07.005.

Friend, P.F., 1977, Distinctive features of some ancient river systems: in Miall, A.D., eds., Fluvial Sedimentology: Memoir 5, Dallas Geological Society, p. 531-542

Gierlowski-Kordesch, E.H., and Rust, R.H., 1994, The Jurassic East Berlin Formation, Hartford Basin, Newark Supergroup (Connecticut and Massachusetts): a saline lake-playa-al- 
luvial plain system, in Renaut, R. W., \& Last, W. M. eds., Sedimentology and geochemistry of modern and ancient saline lakes: SEPM (Society for Sedimentary Geology), Tulsa, OK, p. 249-265, doi:10.2110/pec.94.50.0249.

Gierlowski Kordesch, E.H., and Gibling, M.R., 2012, Pedogenic Mud Aggregates In Rift Sedimentation: Special Publications of SEPM, vol. 71, SEPM (Society for Sedimentary Geology), Tulsa, OK

Giles, J.M., Soreghan, M.J., Benison, K.C., Soreghan, G.S., and Hasiotis, S.T., 2013, Lakes, loess, and paleosols in the Permian Wellington Formation of Oklahoma, U.S.A.: implications for paleoclimate and paleogeography of the midcontinent: Journal of Sedimentary Research, v. 83, p. 825-846, doi:10.2110/jsr.2013.59.

Grant, C.D., and Blackmore, A. V., 1991, Self-mulching behavior in clay soils: its definition and measurement: Australian Journal of Soil Research, v. 29, p. 155-173, doi:10.1071/ SR9910155.

Gu, Y., Schouwstra, R.P., and Rule, C., 2014, The value of automated mineralogy: Minerals Engineering, v. 58, p. 100-103, doi:10.1016/J.MINENG.2014.01.020.

Hall, S.A., Miller, M.R., and Goble, R.J., 2010, Geochronology of the bolson sand sheet, New Mexico and Texas, and its archaeological significance: Bulletin of the Geological Society of America, v. 122, p. 1950-1967, doi:10.1130/B30173.1.

Hardie, L.A., Smoot, J.P., and Eugster, H.P., 2009, Saline lakes and their deposits: a sedimentological approach, in Matter, A. and Tucker, M.E. eds., Modern and Ancient Lake Sediments, Blackwell Publishing Ltd., v. 2, p. 7-41, doi:10.1002/9781444303698.ch2.

Hartley, A.J., Weissmann, G.S., Nichols, G.J., and Warwick, G.L., 2010, Large distributive fluvial systems: characteristics, distribution, and controls on development: Journal of Sedimentary Research, v. 80, p. 167-183, doi:10.2110/jsr.2010.016.

Hasiotis, S.T., Kraus, M.J., and Demko, T.M., 2007, Climatic controls on continental trace fossils, in William Miller, I. ed., Trace fossils: concepts, problems, prospects, Elsevier, p. 172-195, doi:10.1016/B978-044452949-7/50137-6.

Hayden, F. V, 1872, Preliminary report of the US Geological Survey of Montana portions of adjacent Territories, being a fifth annual report of progress: Government Printing Office, Washington, DC

Herbert, C.M., and Alexander, J., 2018, bottomset architecture formed in the troughs of dunes and unit bars: Journal of Sedimentary Research, v. 88, p. 522-553, doi:10.2110/ 123 
jsr.2018.28.

Herbert, C.M., Alexander, J., Amos, K.J., and Fielding, C.R., 2020, Unit bar architecture in a highly-variable fluvial discharge regime: Examples from the Burdekin River, Australia: Sedimentology, v. 67, p. 576-605, doi:10.1111/sed.12655.

Herbert, C.M., Alexander, J., and Martínez de Álvaro, M.J., 2015, Back-flow ripples in troughs downstream of unit bars: formation, preservation and value for interpreting flow conditions: Sedimentology, v. 62, p. 1814-1836, doi:10.1111/sed.12203.

Hopkins, A.D., 2011, The Black Hills beetle,: Iowa, Kendall/Hunt, R/H Geology Field Guide Series, 190 p., doi:10.5962/bhl.title.37314.

Van Houten, F.B., 1973, Origin of Red Beds A Review-1961-1972: Annual Review of Earth and Planetary Sciences, v. 1, p. 39-61, doi:10.1146/annurev.ea.01.050173.000351.

Hu, X., Jansa, L., Wang, C., Sarti, M., Bak, K., Wagreich, M., Michalik, J., and Soták, J., 2005, Upper Cretaceous oceanic red beds (CORBs) in the Tethys: occurrences, lithofacies, age, and environments: Cretaceous Research, v. 26, p. 3-20, doi:10.1016/j.cretres.2004.11.011.

Huey, R.B., and Ward, P.D., 2005, Hypoxia, global warming, and terrestrial Late Permian extinction: Science, v. 308, p. 398-401, doi:10.1126/science.1108019.

Irmen, A.P., and Vondra, C.F., 2000, Aeolian sediments in lower to middle (?) Triassic rocks of central Wyoming: Sedimentary Geology, v. 132, p. 69-88, doi:10.1016/S00370738(99)00129-3.

Isbell, J.L., Lenaker, P.A., Askin, R.A., Miller, M.F., and Babcock, L.E., 2003, Reevaluation of the timing and extent of late Paleozoic glaciation in Gondwana: role of the Transantarctic Mountains: Geology, v. 31, p. 977-980, doi:10.1130/G19810.1.

Johnson, E.A., 1993, Depositional history of Triassic rocks in the area of the Powder River Basin, northeastern Wyoming, and southeastern Montana: Denver, U.S. G.P.O., U.S. Geological Survey Bulletin, 30 p.

Kessler, J.L.P., Soreghan, G.S., and Wacker, H.J., 2001, Equatorial aridity in Western Pangea: Lower Permian loessite and dolomitic paleosols in northeastern New Mexico, U.S.A.: Journal of Sedimentary Research, v. 71, p. 817-832, doi:10.1306/2dc4096b-0e47-11d7$8643000102 \mathrm{c} 1865 \mathrm{~d}$.

Kocurek, G.A., and Nielson, J., 1986, Conditions favorable for the formation of warm-climate 
aeolian sand sheets: Sedimentology, v. 33, p. 795-816, doi:10.1111/j.1365-3091.1986. tb00983.x.

Kraus, M.J., and Aslan, A., 2009, Palaeosol sequences in floodplain environments: a hierarchical approach, in Thiry, M. and Simon-Coinçon, R. eds., palaeoweathering, palaeosurfaces and related continental deposits, Blackwell Publishing Ltd., p. 303-321, doi:10.1002/9781444304190.ch12.

Kühn, P., Aguilar, J., Miedema, R., and Bronnikova, M., 2018, textural pedofeatures and related horizons, in Interpretation of micromorphological features of soils and regoliths, doi:10.1016/b978-0-444-63522-8.00014-0.

Kutzbach, J.E., and Gallimore, R.G., 1989, Pangaean climates: megamonsoons of the megacontinent: Journal of Geophysical Research: Atmospheres, v. 94, p. 3341-3357, doi:10.1029/JD094iD03p03341.

Langford, R.P., 2000, Nabkha (coppice dune) fields of south-central New Mexico, USA: Journal of Arid Environments, v. 46, p. 25-41, doi:10.1006/jare.2000.0650.

Licht, A., Pullen, A., Kapp, P., Abell, J., and Giesler, N., 2016, Eolian cannibalism: reworked loess and fluvial sediment as the main sources of the Chinese Loess Plateau: GSA Bulletin, v. 128, p. 944-956, doi:10.1130/B31375.1.

Limarino, C.O., Césari, S.N., Spalletti, L.A., Taboada, A.C., Isbell, J.L., Geuna, S., and Gulbranson, E.L., 2014, A paleoclimatic review of southern South America during the late Paleozoic: a record from icehouse to extreme greenhouse conditions: Gondwana Research, v. 25, p. 1396-1421, doi:10.1016/j.gr.2012.12.022.

Loope, D.B., Steiner, M.B., Rowe, C.M., and Lancaster, N., 2004, Tropical westerlies over Pangaean sand seas: Sedimentology, v. 51, p. 315-322, doi:10.1046/j.13653091.2003.00623.x.

Love, J.D., 1939, Geology along the southern margin of the Absaroka Range, Wyoming: Geological Society of America Special Papers, v. 20, p. 1-125, doi:10.1130/SPE20-p1.

Lovelace, D.M., and Doebbert, A.C., 2015, A new age constraint for the Early Triassic Alcova Limestone (Chugwater Group), Wyoming: Palaeogeography, Palaeoclimatology, Palaeoecology, v. 424, p. 1-5, doi:10.1016/j.palaeo.2015.02.009.

Lovelace, D.M., and Lovelace, S.D., 2012, Paleoenvironments and paleoecology of a lower Triassic invertebrate and vertebrate ichnoassemblage from the Red Peak Formation (Chugwater Group), Central Wyoming: PALAIOS, v. 27, p. 636-657, doi:10.2110/ 125 
palo.2012.p12-011r.

Lowenstein, T.K., and Hardie, L.A., 1985, Criteria for the recognition of salt-pan evaporites: Sedimentology, v. 32, p. 627-644, doi:10.1111/j.1365-3091.1985.tb00478.x.

Lucas, S.G., 2017, Permian tetrapod extinction events: Earth-Science Reviews, v. 170, p. 31-60, doi:10.1016/j.earscirev.2017.04.008.

Marcelino, V., Schaefer, C.E.G.R., and Stoops, G., 2018, Oxic and related materials, in Interpretation of micromorphological features of soils and regoliths, Elsevier, p. 663-689, doi:10.1016/b978-0-444-63522-8.00023-1.

Matter, A., and Tucker, M.E., 2009, Modern and ancient lake sediments: Blackwell Publishing Ltd., 1-290 p., doi:10.1002/9781444303698.

Maughan, E., 1964, US Geological Survey Professional Paper 50: The Goose Egg Formation in the Laramie Range and adjacent parts of southeastern Wyoming: US Government Printing Office, Washington DC

McGarry, D., 1996, The structure and grain size distribution of vertisols: Developments in Soil Science, v. 24, p. 231-259, doi:10.1016/S0166-2481(96)80009-2.

Miall, A.D., 1977, A review of the braided-river depositional environment: Earth Science Reviews, v. 13, p. 1-62, doi:10.1016/0012-8252(77)90055-1.

Miall, A.D., 1985, Architectural-element analysis: a new method of facies analysis applied to fluvial deposits: Earth Science Reviews, v. 22, p. 261-308, doi:10.1016/00128252(85)90001-7.

Miall, A.D., 1988, Architectural elements and bounding surfaces in fluvial deposits: anatomy of the Kayenta formation (lower Jurassic), Southwest Colorado: Sedimentary Geology, v. 55, p. 233-262, doi:10.1016/0037-0738(88)90133-9.

Mitten, A.J., Howell, L.P., Clarke, S.M., and Pringle, J.K., 2020, Controls on the deposition and preservation of architectural elements within a fluvial multi-storey sandbody: Sedimentary Geology, v. 401, doi:10.1016/j.sedgeo.2020.105629.

Montañez, I.P., and Poulsen, C.J., 2013, The Late Paleozoic ice age: an evolving paradigm: Annual Review of Earth and Planetary Sciences, v. 41, p. 629-656, doi:10.1146/annurev. earth.031208.100118.

Muller, R., Nystuen, J.P., and Wright, V.P., 2004, Pedogenic mud aggregates and paleosol development in ancient dryland river systems: criteria for interpreting alluvial mudrock 
origin and floodplain dynamics: Journal of Sedimentary Research, v. 74, p. 537-551, doi:10.1306/010704740537.

Nichols, G.J., and Fisher, J.A., 2007, Processes, facies and architecture of fluvial distributary system deposits: Sedimentary Geology, v. 195, p. 75-90, doi:10.1016/j.sedgeo.2006.07.004.

North, C.P., and Davidson, S.K., 2012, Unconfined alluvial flow processes: recognition and interpretation of their deposits, and the significance for palaeogeographic reconstruction: Earth-Science Reviews, v. 111, p. 199-223, doi:10.1016/j.earscirev.2011.11.008.

Parrish, J.T., 1993, Climate of the Supercontinent Pangea: The Journal of Geology, v. 101, p. 215-233, doi:10.1086/648217.

Paull, R.A., and Paull, R.K., 1992, Regional significance of Lower Triassic Dinwoody Formation at Conant Creek Anticline, Fremont County, Wyoming: p. 31-35.

Paull, R.K., and Paull, R.A., 1994, Shallow marine sedimentary facies in the earliest Triassic (Griesbachian) Cordilleran miogeocline, U.S.A. (Y. Makino, Ed.): Sedimentary Geology, v. 93, p. 181-191, doi:10.1016/0037-0738(94)90004-3.

Paull, R.A., and Paull, R.K., 1993, Stratigraphy of the Lower Triassic Dinwoody Formation in the Wind River basin area, Wyoming: in Keefer-William, R., Wyoming Geological Association special symposium on oil and gas and other resources of the Wind River basin, Wyoming: Wyoming Geological Association, Laramie, WY, p. 47.

Paull, R.A., Paull, R.K., 1991, Enigmatic uppermost Permian-lowermost Triassic stratigraphic relations in the northern Bighorn Basin of Wyoming and Montana: AAPG Bulletin, v. 75, p. 1136

Payne, J.L., and Kump, L.R., 2007, Evidence for recurrent Early Triassic massive volcanism from quantitative interpretation of carbon isotope fluctuations: Earth and Planetary Science Letters, v. 256, p. 264-277, doi:10.1016/j.eps1.2007.01.034.

Picard, M.D., 1965, Iron oxides and fine-grained rocks of Red Peak and Crow Mountain Members, Chugwater (Triassic) Formation, Wyoming: Journal of Sedimentary Research, v. 35, p. 464-479, doi:10.1306/74D712AD-2B21-11D7-8648000102C1865D.

Picard, M.D., 1966, Stratigraphy and depositional environments of the Red Peak Member of the Chugwater Formation (Triassic), west-central Wyoming: Rocky Mountain Geology, v. 6, p. 904-926, doi:10.1306/74D715BE-2B21-11D7-8648000102C1865D. 
Picard, M.D., Aadland, R., High, L.R., and Jr, 1969, Correlation and stratigraphy of Triassic Red Peak and Thaynes formations, Western Wyoming and adjacent Idaho: AAPG Bulletin, v. 53, p. 2274-2289.

Picard, M.D., and High, L.R., 1963, Rhythmic alternation in the Triassic Chugwater and Brunswick formations, Wyoming and New Jersey: Rocky Mountain Geology, v. 2, p. 87-99.

Posamentier, H.W., and Walker, R.G., 2006, Facies models revisited: SEPM Special Publication 84 , Society for sedimentary geology, Tulsa, OK.

Rasmussen, D.L., and Bean, D.W., 1984, Dissolution of Permian Salt and Mesozoic Syndepositional Trends, Central Powder River Basin, Wyoming: in Goolsby, J., and Morton, D., eds., The Permian and Pennsylvanian Geology of Wyoming; 35th Annual Field Conference Guidebook, Wyoming Geological Association, Laramie, WY p. 281-294.

Retallack, G.J., 1998a, Adapting soil taxonomy for use with paleosols: Quaternary International, v. 51-52, p. 55-57, doi:10.1016/S1040-6182(98)00039-1.

Retallack, G.J., 1998b, Core concepts of paleopedology: Quaternary International, v. 51-52, p. 203-212, doi:10.1016/S1040-6182(97)00046-3.

Retallack, G.J., Sheldon, N.D., Carr, P.F., Fanning, M., Thompson, C.A., Williams, M.L., Jones, B.G., and Hutton, A., 2011, Multiple Early Triassic greenhouse crises impeded recovery from Late Permian mass extinction: Palaeogeography, Palaeoclimatology, Palaeoecology, v. 308, p. 233-251, doi:10.1016/j.palaeo.2010.09.022.

Retallack, G.J., Smith, R.M.H., and Ward, P.D., 2003, Vertebrate extinction across Permian-Triassic boundary in Karoo Basin, South Africa: Bulletin of the Geological Society of America, v. 115, p. 1133-1152, doi:10.1130/B25215.1.

Rust, B.R., and Nanson, G.C., 1989, Bedload transport of mud as pedogenic aggregates in modern and ancient rivers: Sedimentology, v. 36, p. 291-306, doi:10.1111/j.1365-3091.1989.tb00608.x.

Shen, Z., Törnqvist, T.E., Mauz, B., Chamberlain, E.L., Nijhuis, A.G., and Sandoval, L., 2015, Episodic overbank deposition as a dominant mechanism of floodplain and delta-plain aggradation: Geology, v. 43, p. 875-878, doi:10.1130/G36847.1.

Smalley, I. J. 1966, The properties of glacial loess and the formation of loess deposits: Journal of Sedimentary Research, v. Vol. 36, p. 669-676, doi:10.1306/74d7153c-2b21-11d7$8648000102 \mathrm{c} 1865 \mathrm{~d}$. 
Smoot, J.P., and Castens-Seidell, B., 1994, Sedimentary features produced by efflorescent salt crusts, Saline Valley and Death Valley, California: Sedimentology and geochemistry of modern and ancient saline lakes, p. 73-90, doi:10.2110/pec.94.50.0073.

Soil Survey Staff, 1994, Keys to Soil Taxonomy, 2010: Soil Conservation Service, US Government Printing Office, Washington DC

Soreghan, G.S., Soreghan, M.J., and Hamilton, M.A., 2008a, Origin and significance of loess in late Paleozoic western Pangaea: A record of tropical cold? Palaeogeography, Palaeoclimatology, Palaeoecology, v. 268, p. 234-259, doi:10.1016/j.palaeo.2008.03.050.

Soreghan, G.S., Soreghan, M.J., Poulsen, C.J., Young, R.A., Eble, C.F., Sweet, D.E., and Davogustto, O.C., 2008b, Anomalous cold in the Pangaean tropics: Geology, v. 36, p. 659-662, doi:10.1130/G24822A.1.

Soreghan, G.S., Sweet, D.E., and Heavens, N.G., 2014, Upland glaciation in tropical Pangaea: geologic evidence and implications for Late Paleozoic climate modeling: The Journal of Geology, v. 122, p. 137-163, doi:10.1086/675255.

Storrs, G.W., 1991, Anatomy and relationships of Corosaurus alcovensis (Diapsida: Sauropterygia) and the Triassic Alcova Limestone of Wyoming: Bulletin of the Peabody Museum of Natural History, Yale University, v. 44, p. 1-151.

Story, S., Bowen, B.B., Benison, K.C., and Schulze, D.G., 2010, Authigenic phyllosilicates in modern acid saline lake sediments and implications for Mars: Journal of Geophysical Research, v. 115, doi:10.1029/2010JE003687.

Sun, J., 2002, Provenance of loess material and formation of loess deposits on the Chinese Loess Plateau: Earth and Planetary Science Letters, v. 203, p. 845-859, doi:10.1016/ S0012-821X(02)00921-4.

Tabor, N.J., 2007, Permo-Pennsylvanian palaeotemperatures from Fe-Oxide and phyllosilicate $\delta 180$ values: Earth and Planetary Science Letters, v. 253, p. 159-171, doi:10.1016/j. eps1.2006.10.024.

Tabor, N.J., 2013, Wastelands of tropical Pangea: high heat in the Permian: Geology, v. 41, p. 623-624, doi:10.1130/focus052013.1.

Tabor, N.J., and Montañez, I.P., 2002, Shifts in late Paleozoic atmospheric circulation over western equatorial Pangea: Insights from pedogenic mineral $\delta 180$ compositions: Geology, v. 30, p. 1127-1130, doi:10.1130/0091-7613(2002)030<1127:SILPAC>2.0.CO;2. 
Tabor, N.J., and Poulsen, C.J., 2008, Palaeoclimate across the Late Pennsylvanian-Early Permian tropical palaeolatitudes: a review of climate indicators, their distribution, and relation to palaeophysiographic climate factors: Palaeogeography, Palaeoclimatology, Palaeoecology, v. 268, p. 293-310, doi:10.1016/j.palaeo.2008.03.052.

Thomas, H.D., 1934, Phosphoria and Dinwoody Tongues in Lower Chugwater of Central and Southeastern Wyoming: AAPG Bulletin, v. 18, p. 1655-1697, doi:10.1306/3d932c9a16b1-11d7-8645000102c1865d.

Tomlinson, C.W., 1916, The origin of red beds: a study of the conditions of origin of the Permo-Carboniferous and Triassic Red Beds of the Western United States: The Journal of Geology, v. 24, p. 238-253, doi:10.2307/30078150.

Tsoar, H., and Pye, K., 1987, Dust transport and the question of desert loess formation: Sedimentology, v. 34, p. 139-153, doi:10.1111/j.1365-3091.1987.tb00566.x.

Wagreich, M., and Krenmayr, H.G., 2005, Upper Cretaceous oceanic red beds (CORB) in the Northern Calcareous Alps (Nierental Formation, Austria): slope topography and clastic input as primary controlling factors: Cretaceous Research, v. 26, p. 57-64, doi:10.1016/j. cretres.2004.11.012.

Walker, T.R., 1967, Color of recent sediments in tropical Mexico: a contribution to the origin of red beds: Geological Society of America Bulletin, v. 78, p. 917-920, doi:10.1130/0016-7606(1967)78[917:CORSIT]2.0.CO;2.

Walker, T.R., 1968, Formation of red beds in modern and ancient deserts: reply: Geological Society of America Bulletin, v. 79, p. 281-282, doi:10.1130/0016-7606(1968)79[281:FORBIM]2.0.CO;2.

Walker, T.R., 1974, Formation of red beds in moist tropical climates: a hypothesis: Geological Society of America Bulletin, v. 85, p. 633-638, doi:10.1130/0016-7606(1974)85<633:FORBIM>2.0.CO;2.

Weissmann, G.S., Hartley, A.J., Nichols, G.J., Scuderi, L.A., Olson, M., Buehler, H., and Banteah, R., 2010, Fluvial form in modern continental sedimentary basins: distributive fluvial systems: Geology, v. 38, p. 39-42, doi:10.1130/G30242.1.

Wentworth, C.K., 1922, A scale of grade and class terms for clastic sediments: The journal of Geology, v. 30, p. 377-392.

Wolman, M.G., and Leopold, L.B., 1957, River flood plains: some observations on their formation: Geological Survey Professional Paper 282-C, US Government Printing Office, 
Washington, DC.

Yang, J., Cawood, P.A., Du, Y., Li, W., and Yan, J., 2016, Reconstructing Early Permian tropical climates from chemical weathering indices: GSA Bulletin, v. 128, p. 739-751, doi:10.1130/B31371.1.

Yechieli, Y., and Wood, W.W., 2002, Hydrogeologic processes in saline systems: playas, sabkhas, and saline lakes: Earth-Science Reviews, v. 58, p. 343-365, doi:10.1016/S00128252(02)00067-3.

Zambito, J.J., and Benison, K.C., 2013, Extremely high temperatures and paleoclimate trends recorded in Permian ephemeral lake halite: Geology, v. 41, p. 587-590, doi:10.1130/ G34078.1. 


\section{CHAPTER 4}

Title: The Permian-Triassic red beds of the Red Peak Formation, Wyoming (USA) Part II: The origin of red pigment from pre-depositional and pedogenic processes

Intended for Publication in: Sedimentology

Authors:

JONATHAN P. KNAPP ${ }^{1,2}$, KATHLEEN C. BENISON ${ }^{1}$

${ }^{1}$ Department of Geology and Geography, West Virginia University, Morgantown, West Virginia, U.S.A. 26506-6300

${ }^{2}$ Bruker Nano Analytics, Berlin, 12489, Germany;

Corresponding Author: Jonathan Knapp, Jonathan.Knapp@,bruker.com

Keywords: Red Peak, Chugwater, Triassic, iron oxides, red beds, paleosols, red beds 


\begin{abstract}
The Red Peak Formation of the Chugwater Group (Wyoming, USA), pedogenically-altered distal alluvial fan, ephemeral saline lake, and mudflat deposits, is an example of red beds characteristic of many Permian-Triassic continental deposits. Previous studies have suggested five general origins of red pigments in red beds: (1) reworking of red soils formed as tropical laterites; (2) in-situ formation of intergranular iron oxide cement by pedogenesis and early diagenesis in saline mudflats in the presence of Fe-bearing groundwaters; (3) reddening during transportation and mixing; (4) direct precipitation of tiny iron oxide crystals in acid saline lake waters; and (5) post-compaction diagenesis. Here, a detailed petrographic study of the Red Peak Formation is presented to ascertain the processes resulting in its red color, to determine if the red color can inform models of deposition for other red beds in the midcontinent, and to evaluate the potential roles of water chemistry and climate on red bed formation.
\end{abstract}

Iron oxides were observed in three general types: (1) coatings on grains, (2) detrital iron oxide grains, and (3) red clays. Grain coatings are rims of iron oxide on grains of quartz or other minerals. Some grain coatings, particularly those on quartz grains, are thin $(<1 \mu \mathrm{m})$, discontinuous layers that show signs of abrasion; others are thick (up to $4 \mu \mathrm{m}$ ) coatings. Detrital iron oxide grains are porous, angular, coarse silt grains. Red clays occur as mud-sized red clay mineral coatings around grains and as pedogenic aggregates, as pore-filling clays, and as a red

The red pigment in the Red Peak Formation formed either before deposition or during a pedogenic process shortly after deposition. Thick iron oxide coatings and detrital iron oxide grains most likely originated from the near-surface precipitation of iron oxide in acid saline lakes and by acid saline groundwaters. Thin coatings likely formed during impact with other grains during saltation, imparting red pigment from associated clays. Soil reddening transpired when oxidizing, Fe-rich groundwater in warm conditions underwent ferrolysis.

The long-term soil stability required to generate the red color resulted in flat, laterally extensive units. Widespread hypersaline groundwater, acid saline lakes, high temperatures, arid climate, and availability of fine-grained sediment with abundant reactive iron all likely contributed to the near-global continental formation of red beds during Permian-Triassic time. 


\section{INTRODUCTION AND SIGNIFICANCE}

During Permian-Triassic time, thick packages of distinctive red bed sediments and associated evaporites formed throughout much of Pangea (Fig. 1). The Lower Triassic Red Peak Formation of Wyoming (USA) is an example of these distinctive rocks. Thick successions of red beds exist in western Europe, the western interior of the United States and Canada, the eastern United States, Russia, China, South America, southern Africa, India, and eastern Australia (Tomlinson, 1916; Waugh, 1973; Van Houten, 1973; Blakey et al., 1988; Parrish, 1993; Scholle et al., 1995; Limarino et al., 2014). In North America, red beds and evaporites of the Permian-Triassic age are widespread (Fig. 2). Permian-Triassic red beds formations include the Red Peak, Goose Egg, Chinle, Dewey Lake, Moenkopi, Supai, Spearfish, Opeche, and Cutler Formations, as well as the Sumner, Nippewalla, and Quartermaster Groups, covering a significant portion of the supercontinent Pangea (Darton, 1899, 1906; Burk et al., 1956; Baars, 1961; Brill, 1963; Picard, 1965; Blakey, 1990; Dubiel et al., 1991; Steiner et al., 1996; Benison and Goldstein, 2001; Banham and Mountney, 2013). The transition from coals and fluvial sandstones of the Pennsylvanian and early Permian to red beds and evaporites of the late Permian and Triassic records a long-term trend of warming, drying, and atmospheric $\mathrm{CO}_{2}$ increase (Tabor and Montañez, 2002; Royer et al., 2004; Tabor and Poulsen, 2008; Tabor, 2013 and references therein).

The Red Peak Formation belongs to a class of Permian-Triassic red beds proven particularly problematic to fit into preexisting facies models. Defining characteristics of these fine-grained, chemically immature sandstones and siltstones are a red-orange color, spatially-extensive layer-cake bedding, an association with gypsum and halite, a paucity of body and trace fossils, and a distinctive alternating resistant-recessive bedding pattern. Examples of similar red beds include the Spearfish Formation of the Black Hills and Williston Basin (USA; (Dow, 1964), the Lower Watrous red beds of south-central Canada (Cumming, 1956; Butcher et al., 2012), and the Cumbrian Coastal and Sherwood Sandstone Groups in northwestern England and southwestern Scotland (Brookfield, 2004). The red pigmentation in the Red Peak Formation has been interpreted as originating during post-compaction diagenesis (Picard, 1965). A post-burial origin contrasts with the proposed genesis of other Permian-Triassic red beds where the red pigment is interpreted to have formed from the early surface or near-surface processes intimately related to climate and environment (Braddock, 1963; Walker, 1967b, 1974; Van Houten, 1973; Dubiel and Smoot, 1994; Sheldon, 2005).

Three environmental models have been previously proposed for the reddening of sediments at the surface: (1) eolian sediment impact, (2) soil weathering, (3) and lacustrine iron oxide precipitation. Eolian sediment impact reddening occurs by the physical, subaerial impact of sediment 
grains with one another in the presence of red clay (El-Baz, 1986). Soils become red through the liberation of iron from mineral soil constituents and the incorporation into a clay matrix (Walker, 1967b, 1974; Buol and Eswaran, 1999). Some lakes and adjacent shallow groundwaters, such as those of the Permian and Triassic of North America and Northern Ireland and modern Western Australia, precipitate iron oxides (Benison et al., 1998, 2007; Andeskie et al., 2018). Transportation of soil-reddened material and post compaction expulsion of reddening fluids have been proposed in addition to in-situ environmental reddening (Tomlinson, 1916; Picard, 1965; Van Houten, 1973).
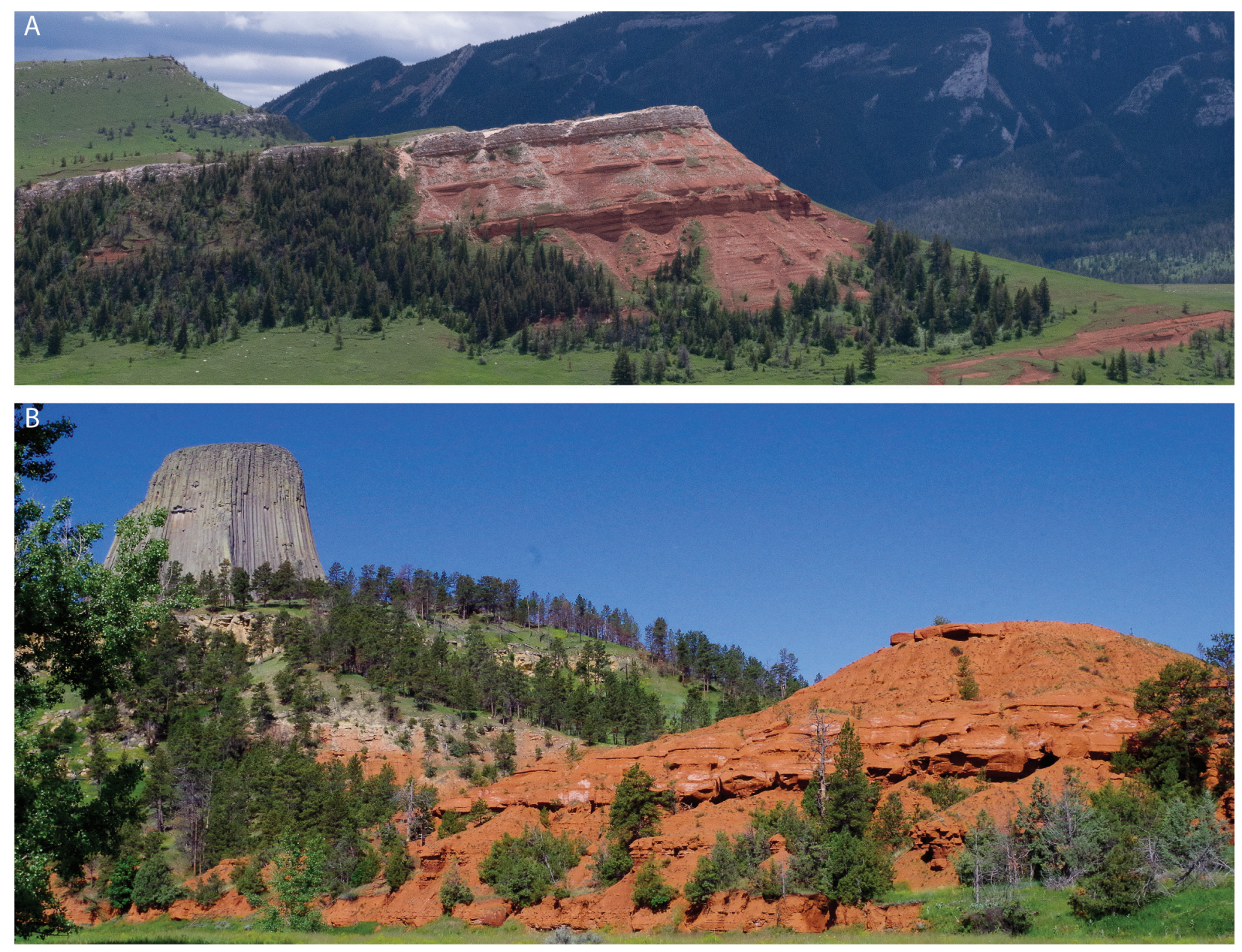

Fig. 1: Landscapes of the Red Peak Formation in Wyoming. (A) The Red Peak Formation along the Chief Joseph Highway (Wyoming 296) between Cody Wyoming and Yellowstone National Park. A thick gypsum unit overlies the Red Peak. (B) The Red Peak Formation with Devils Tower National Monument in the background. The Red Peak Formation, known locally and in South Dakota as the Spearfish Formation, is the "red racetrack" of Native American legend. According to this legend, man and buffalo race to determine who will order the universe, and it was the race that raised the Black Hills and the blood from the runner's feet that stained the rocks red. 


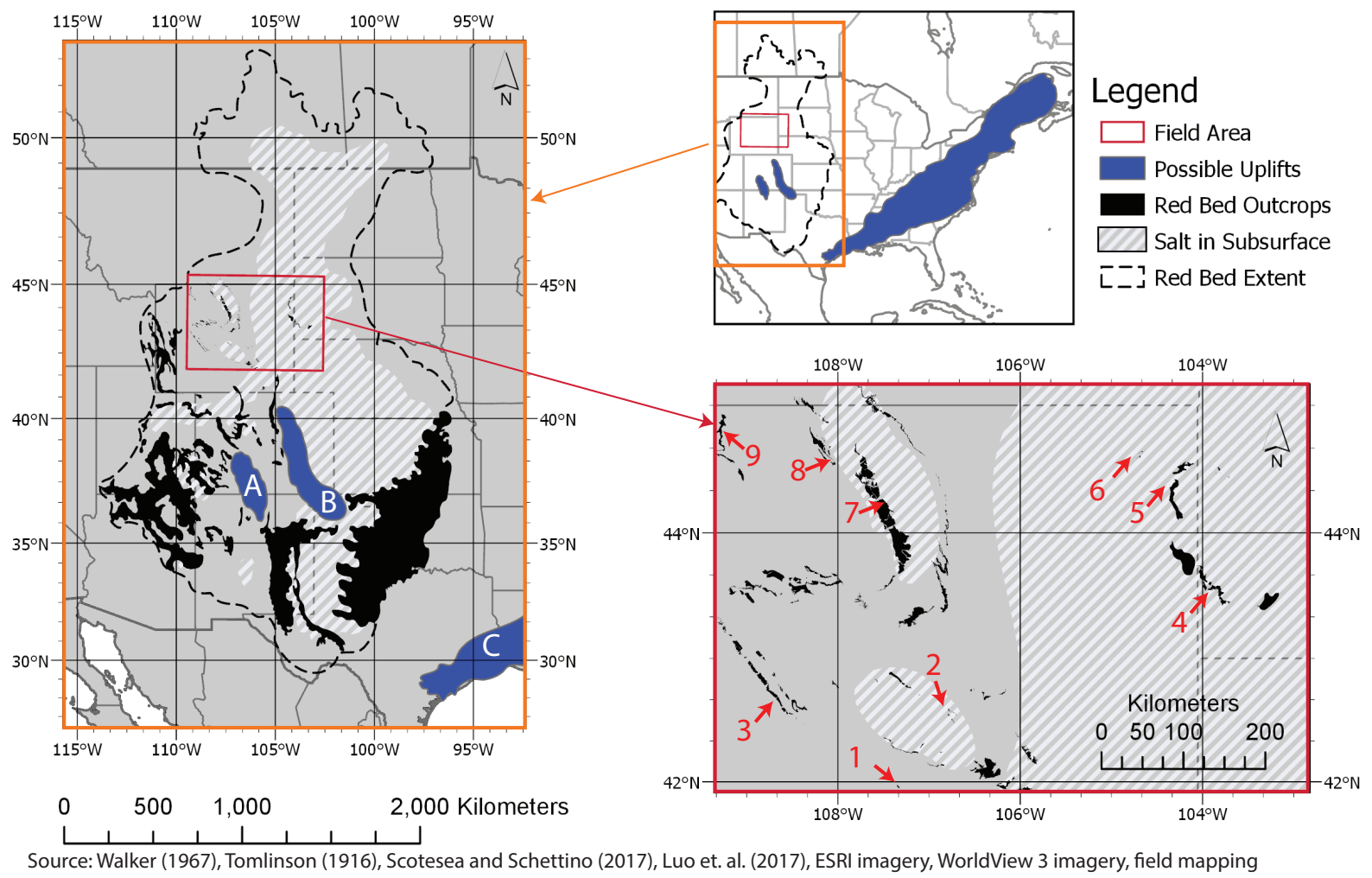

Fig. 2: Regional location map (orange box) of the Permian-Triassic red bed system in mid-continent North America (within the dashed line) and detail of the Wyoming study area (red box). Red beds outcrop (black area) from Kansas in the east to Nevada's eastern border in the west and from Canada to at-least Texas's southern border. Evaporites are in the subsurface (white hash) in all possible units. Possible uplifts (blue), and thus sources for sediment, include the Uncompahgre Highlands (A), Ancestral Front Range (B), and Central Pangea Mountains (C). Field locations mentioned in the text are Willow Hill (1), Alcova Reservoir (2), Red Valley (3), southern Black Hills (4), northern Black Hills (5), Devils Tower (6), Shell Canyon (7), and Chief Joseph Highway (8). 
Fig. 3: Stratigraphic nomenclature and relationships in the Red Peak Formation. Agedbased correlations are problematic in units without datable fossils, ash layers, marine sediments, or sediments that can be correlated over long distances.

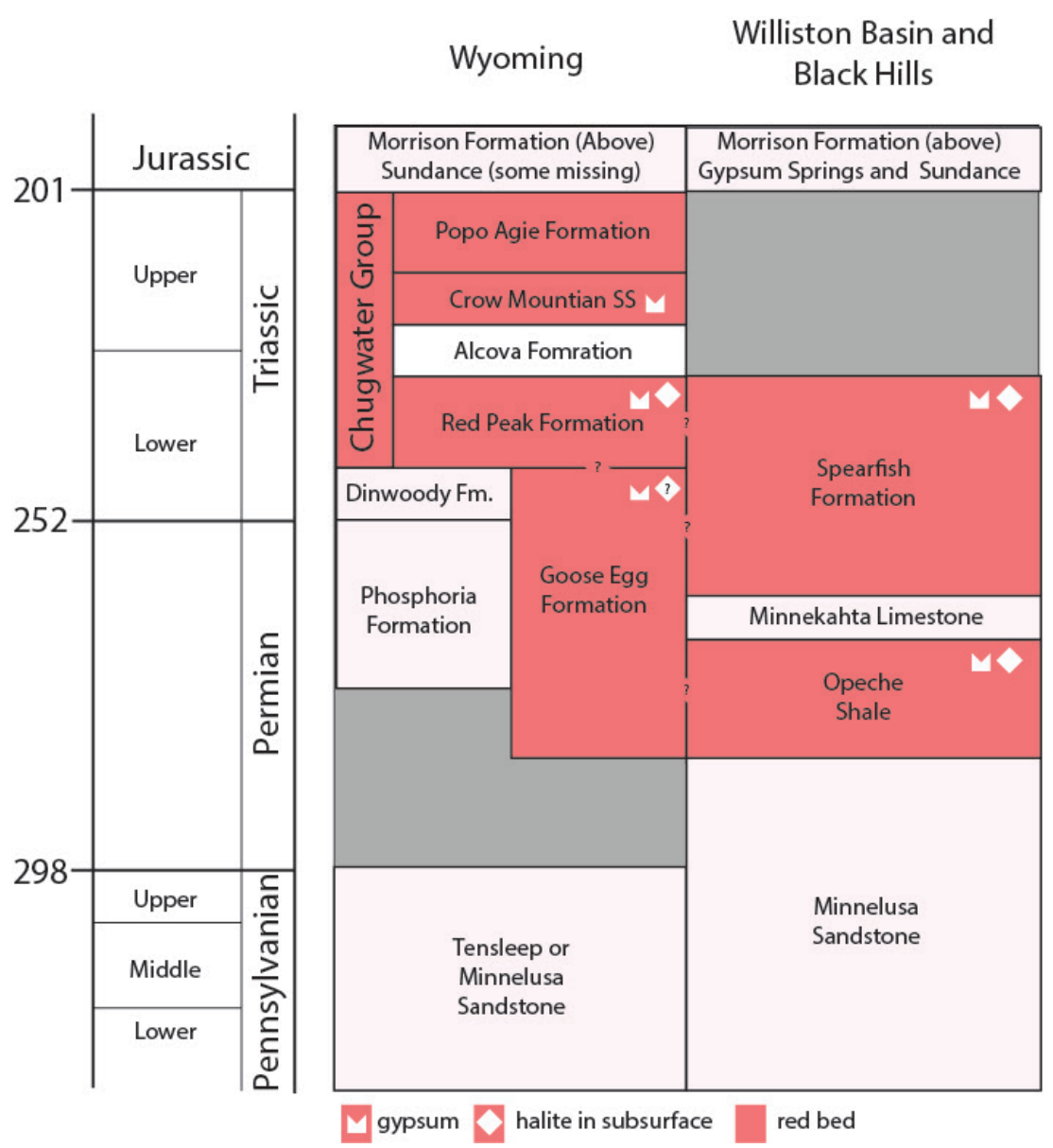

This study aimed to use detailed petrography to test different reddening types in the Triassic Red Peak Formation in Wyoming. Implications may include diagnostic features for reddening processes common to Permian-Triassic red beds of Pangea. This study follows a recent paper that documents the depositional environments of the Red Peak Formation (Chapter 2) and, thus, allows the reddening problem to be placed within the context of detailed lithological descriptions.

\section{THE RED BED QUESTION}

The origin and significance of red pigment in red beds, along with the climatic significance of that pigment, have been debated since the first exploration of the Permian in Europe (Murchison and Strickland, 1840; Murchison, 1841; Murchison and Harkness, 1864) and the United States (Hayden et al., 1862; Tomlinson, 1916). For much of the $20^{\text {th }}$ century, the prevailing wisdom was that red beds were transported ferruginous sediment. Tomlinson (1916), in his early work on western red beds, summarized, "it seems a safe conclusion that the coloring matter of the Red Beds was transported and deposited almost if not quite wholly as mechanical sediment; and. therefore, without danger of serious error, we may limit investigations of possible conditions of 
origin of this coloring matter to those which would produce it as mechanical sediment purely." Observations of red soils eroding on alluvial plains in Mexico further reinforced the perception that all red beds were recycled from upland oxisols that were thin with a low preservation potential (Dorsey, 1926; Krynine, 1935).

Oxisols of modern soil taxonomy were formally known as Laterites, Latosols, various Lateritic soils, Ferrisols, Kaolisols, and Ferralsols. Oxisols are soils with an oxic horizon within $150 \mathrm{~cm}$ of the mineral soil surface, low cation-exchange, low content of primary minerals, and no accumulations through additions such as calcite horizons (Soil Survey Staff, 1994). Oxisols form from the protracted process of desilication and the formation of clays in the presence of iron-bearing silicates in well-oxygenated conditions (Buol and Eswaran, 1999). The red color is derived by incorporating sub-micron iron oxide nanoparticles between clay crystal layers during in-situ weathering (Widdowson and Gunnell, 1995; Schwertmann and Taylor, 2018). Oxisols are most common in tropical regions, where high rainfall and long-term soil stability have largely replaced original grains with iron-rich clays (Buol and Eswaran, 1999). It was a commonly accepted trope that red beds were either formed as tropical oxisols or had been weathered from the same, a view reinforced by early $20^{\text {th }}$ century observations in the tropics, like that of Krynine (1935) in Mexico.

Walker (1967a) revisited the Tabasco savanna, where Krynine (1935) had reported the transportation of red sediment from the mountains. As a result of detailed sampling and observation, Walker demonstrated that the mountains' fluvial systems transported brown to dark greyish brown sediment (10YR 3/2, 10YR 5/2, $10 \mathrm{YR} 4 / 2$ ), not red. Red sediment formed in situ from the breakdown of iron-rich detrital grains in the presence of oxygenated interstitial water (above or below groundwater table) in warm $\left(>18^{\circ} \mathrm{C}\right)$ climates (Walker, 1967b). The formation of hydrated ferric minerals (e.g., limonite) progressed more quickly in hot and humid climates but was possible in an arid environment. In subsequent work, in tropical regions, Walker (1974) demonstrated that insufficient iron oxides could be transported to account for red sediment, but the same process of in-situ near-surface diagenesis could result in the reddening of tropical sediments over time.

The simple presence of red beds alone does not indicate specific climate conditions. Other climate proxies must be used to differentiate the depositional settings of any red bed; for example, red beds associated with coal may indicate warm and humid conditions, and red beds associated with evaporites may suggest an arid climate. Walker (1967b) gives the following conditions for in-situ red bed formation: (1) occurrence of iron-bearing detrital grains; (2) post-depositional 
condition favorable to alteration of iron-bearing grains; (3) and interstitial Eh-pH that favors the formation of ferric oxyhydroxides; (4) absence of subsequent reduction of the ferric iron; (5) long enough time for initial ferric oxyhydroxides to be converted to hematite; and (6) possibly warm temperatures above $\sim 18^{\circ} \mathrm{C}$. In this study, iron oxides will be used to refer to hematite, magnetite, goethite, and all ferric oxyhydroxides.

Iron oxide-coated quartz grains were reported in the 1880s from petrographic studies in the Rub' al Khali by Phillips (1882), who noted that sand's rounding and frosting were ongoing processes and the red pigment was deposited after rounding. McKee (1964) traveled to Africa in 1961 and recognized that red pigmentation increases away from source areas. This observation was confirmed with a specially made Munsell color wheel provided as part of the Apollo-Soyuz Earth Observations and Photography Experiment (NASA Catalog Number 8030 and 8032) with observations made across Australia and North Africa (El-Baz, 1978). Red coatings occur in areas of active sand migration when the saltating population of sand (typically quartz) impact in the presence of red clays. In this scenario, the hematite (or other iron oxides) is transferred to the quartz grain by the percussive force at the impact site (Folk, 1976 and references therein; McKee, 1980; El-Baz, 1986). However, the red clays' origin, predecessor soils in reddening, and interdunal residence's role all deserve further investigation.

Studies of acid ephemeral saline lakes in Australia (Benison et al., 2007) and acid saline lake facies from the Permian and Triassic rocks from North America and Northern Ireland (Benison et al., 1998; Benison and Goldstein, 2002; Andeskie et al., 2018) suggest a previously unrecognized environment for red bed formation. Also, human-made acid mine drainage precipitates iron oxides (Ferris et al., 1989; Blowes et al., 2003). Low pH waters quickly liberate iron, alumina, magnesium, silica, and other ions from minerals by dissolution. Ferrolysis, hydrolysis by waters already enriched in $\mathrm{Fe}^{2+}$, results in iron oxide precipitation and decreases $\mathrm{pH}$ further (Brinkman, 1970; Mann, 1983; Long et al., 2009). Authigenic phyllosilicates also may precipitate from these acid brines. As chemical precipitates from acid saline lake water, iron oxides and phyllosilicates form tiny crystals in the water column deposited on lake bottoms as mud (Benison et al., 2007). Acid saline groundwater below the lakes and the shallow subsurface of adjacent saline mudflats precipitate these minerals as thick grain-coating intergranular cement (Bowen et al., 2012). Iron-oxide concretions and significant soil reddening can occur in less than $3 \mathrm{ka}$ at depths of only centimeters below the surface (Bowen et al., 2008; Story et al., 2010). These observations of iron oxide formation by acid saline lake and ground waters in modern sediments have yet to be considered fully for ancient red beds. 
The redistribution of sediment previously reddened in tropical highlands was the dominant hypothesis for forming red beds (Van Houten, 1973) before Walker's hypothesis. Walker proposed that redbeds can form in situ from various environments and that reddened material is quickly diluted during transport (1967b, 1967a, 1974). The invocation of transport was an attempt to reconcile the reddening of fluvial and other facies that did not fit the concept of "laterites." Picard (1965) evoked post-compaction diagenesis to explain the reddening of lithofacies not associated with tropical soils. Picard used iron analysis and petrology of the Red Peak Formation and recognized iron oxide in the form of grains of iron oxide, grain coatings, and hematite pigment in the matrix material. This red pigment was attributed to a post-depositional event because color differences transgressed across sedimentary structures, no red matrix could be seen between compacted grains, and magnetization of hematite was consistent even in disturbed beds. Picard wrote, "The uniform coloration of the beds requires a mechanism that mobilized and distributed red pigment throughout the rocks. This mobilization is consistent with the redistribution of red pigment during diagenesis, as compaction expelled the contained fluids." The maximum depth of the Chugwater Group has not been studied. However, studies of later Mesozoic rocks and the uplift history suggest a minimum burial depth of $2 \mathrm{~km}$ at the initiation of low-angle subduction of the Farallon oceanic plate during the Late Cretaceous-early Eocene (Crowley et al., 2002; Fan and Carrapa, 2014).

\section{DEPOSITIONAL SETTING}

The Red Peak Formation is a 90 to $110 \mathrm{~m}$ thick stratigraphic unit of chemically immature finegrained red bedded mudstones and rare bedded sandstones and gypsum (Fig. 4, 5; Chapter 3). In outcrop, the most distinctive feature is its color, ranging from bright red (10R 6/4) and light red (2.5YR 7/8) to light greyish red (5YR 7/4) in resistant beds to dark scarlet grey (2.5 YR 4/2) or dark grayish red (5YR 2/2) in recessive beds. The five lithofacies identified are; (1) resistant siltstone and sandy siltstone, (2) ped-overprinted mudstone, (3) bedded gypsum, (4) laminated mudstones, and (5) thin siltstone and sandstone lenses.

The Red Peak Formation's siliciclastics were deposited mostly by unconfined overland flow, weakly channelized overland flow, winds, and lakes. Bedded gypsum likely formed from ephemeral saline lakes. Soils formed after deposition, resulting in laterally continuous horizons defined by peds and some root features. Petrographic evidence for soil formation in resistive beds includes root features, burrow fills clay coatings, and circumgranular cracks filled with red clay 

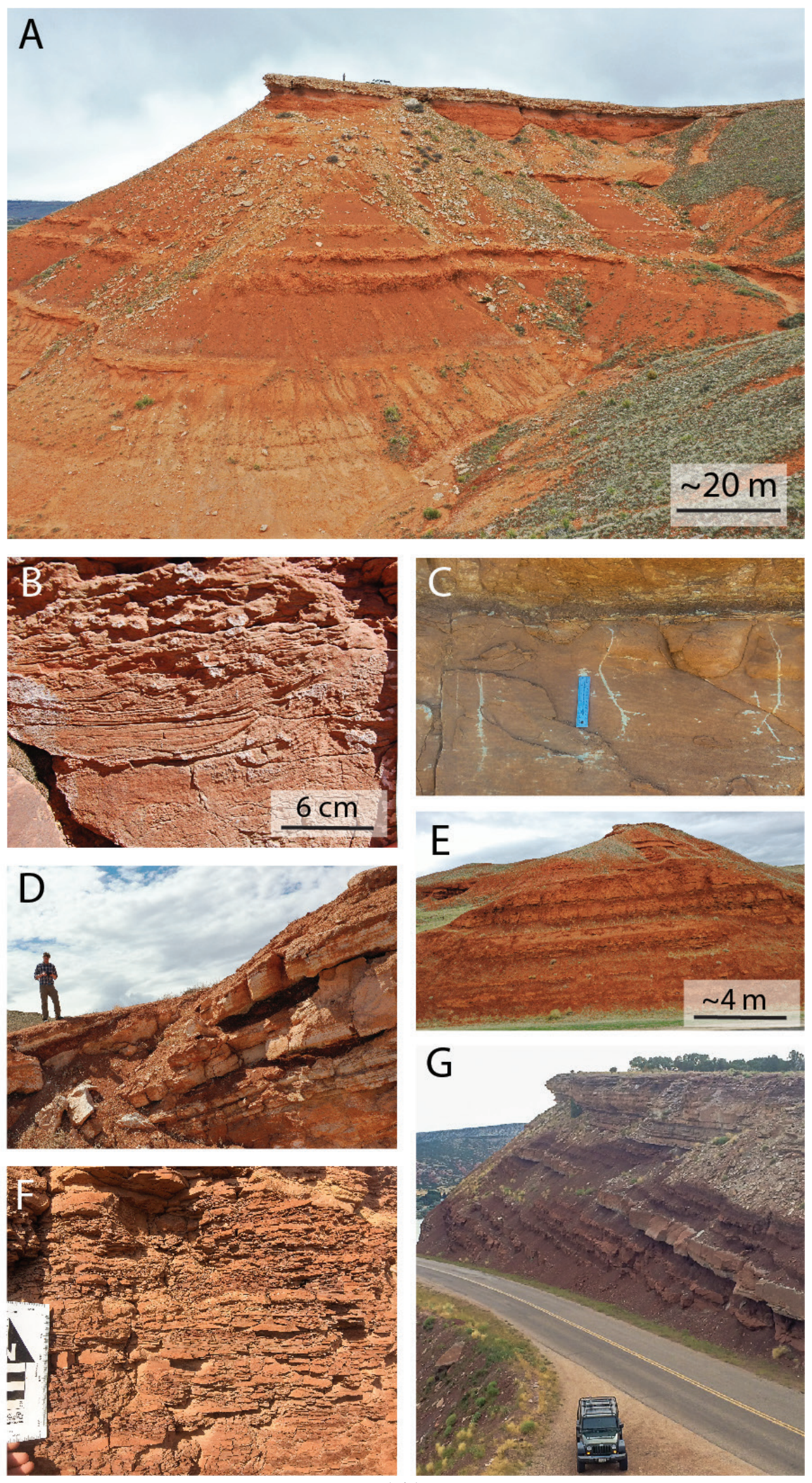
Fig. 4: Examples of Red Peak Formation features in outcrop. (A) Alkali Creek locality with 98 $m$ of Red Peak Formation from the Alcova Limestone at the top to the approximate contact with the Goose Egg Formation at the base. (B) Cross bedding in heterolytic red siltstone and gypsum at the Alcova Reservoir locality. (C) Paleosol features at the Thermopolis locality. The rule is $10 \mathrm{~cm}$ in length. Root features are made visible as reduction features extend down from a darker paleosol. (D) Alternating beds of gypsum and red mud exposed by a landslide at the Wyo-Ben Products mine $31 \mathrm{~km}$ east of the entrance to Shell Canyon. A person for scale is $198 \mathrm{~cm}$ tall. (E) Road-cut exposure of the transition between the Goose Egg Formation and the Red Peak Formation near the entrance to Shell Canyon. (F) Detail of blocky peds from Willow Creek locality. $(G)$ Alternating bedding in the Red Peak Formation below the Alcova Formation at the Alcova Reservoir locality.

(Fig. 6). In recessive beds, pedogenic aggregates form (Fig. 6B, 12). Variations in red coloration in the Red Peak Formation most commonly correspond to soil formation horizons, and the better developed pedogenic features are darker red (Fig, 4C). The localized reduction occurred shortly after the death and decay of roots, resulting in gray (GLEY 1 7N and GLEY 1 6/1) reduction spots and haloes. Thus, some reduced areas likely mark the paleo-groundwater table.

\section{METHODS}

\section{Field Work}

Fieldwork was conducted at the Red Peak Formation outcrops first identified on USGS geologic maps of Wyoming. Fourteen field locations, listed from northcentral Wyoming to southcentral Wyoming, include Bighorn Lake, Georgia-Pacific Gypsum mine, Greybull, Shell Creek, Alkali Creek, Norwood, Ten Sleep, Thermopolis, Red Fork, Bessemer Bend, Casper Mountain, Red Valley, Alcova Reservoir, and Willow Hill (Fig. 1). Also, Landsat satellite and drone imagery were used for regional contextualization of field observations. Fieldwork was conducted from 2014 to 2019. First, reconnaissance fieldwork was performed to survey and confirm outcrop locations. Detailed measured sections (at cm-scale) were described. Representative samples were collected from both recessive and resistant lithofacies at the Willow Hill and Alcova Reservoir localities in 2018 and 2019 for detailed petrology and SEM analysis focused on the red origin pigment.

\section{Petrology}

Three standard-format thin sections and nine standard-format thick sections were prepared at the thin section laboratory at Colorado School of Mines for this study. Three of the thick sections were grain mounts. All sections were mounted in epoxy and polished with $1 \mu \mathrm{m}$ polishing pads 
using minimum pressure, resulting in the first high-quality petrographic slides of fine-grained material from the Red Peak Formation. An Olympus SZX12 microscope with 6.3 - 63 x magnification and an SZX10 microscope with 20 - 2000X magnification was used for petrographic observations. Both microscopes were equipped with transmitted, reflected, and polarized light sources.

Scanning electron microscopy work was conducted on a Hitachi FlexSEM 1000 compact SEM equipped with a Bruker Q80 EDS BSE and SE detectors at Advanced Minerals Characterization Laboratory at the Colorado School of Mines in 2018 and 2019. Images were collected with a 20 $\mathrm{kV}$ acceleration voltage and $10 \mathrm{~mm}$ working distance to optimize EDS measurements. All sam-

ples were mapped with the Advanced Mineral Identification and Classification System (AMICS) software from Bruker at $200 \mathrm{x}$ magnification. Iron minerals were identified from the resulting mineral maps and targeted for detailed imaging and EDS maps. EDS maps were collected using mapping mode in the Bruker Esprit software set at 20 iterations. All SEM imagery was completed on carbon-coated thick sections.

\section{X-Ray Fluorescence}

Fifty-two samples were prepared for elemental analysis by x-ray fluorescence by crushing with a ceramic mortar and pestle and then grinding to a fine powder with a quartz mortar and pestle. Fifty-five samples from Willow Hill and six samples from Alcova Reservoir samples were measured in packed powder sample cups with proline covers on a Bruker Tracer $5 \mathrm{~g}$ portable XRF. The Mudrock Dual calibration (Rowe et al., 2012) modified with Oreas standards 25A, 47, and 403 to increase iron stability was used for quantified results. A silica blank and an Oreas standard 404 were measured after every $10^{\text {th }}$ sample to check for contaminations and instrument stability.

\section{RESULTS}

\section{General Iron Oxide Descriptions}

There is petrographic evidence for at least three forms of iron oxides in the Red Peak Formation: (1) detrital grains of crystalline iron oxide or fully or partially hematitized grains that have been transported; (2) thick and thin iron-oxide coatings or cement on transported grains; and (3) ultrafine pigment within a clay matrix or as clay minerals coating grains. Except for thin iron coatings that were only recognized later, all three types found in all samples examined with 
SEM Total $\mathrm{Fe}_{2} \mathrm{O}_{3}$ (reported as oxide by convention) ranges from $0.23 \%$ to $5.89 \%$ and averages $2.98 \%$ in the 54 samples of the Red Peak Formation samples analyzed by XRF (Fig. 5).

\section{Detrital Iron Oxide Grains}

\section{Descriptions}

Detrital monocrystalline or polycrystalline grains of iron oxide (Fig. 8 are present as slightly oblong, angular to sub-angular fragments between $10 \mu \mathrm{m}$ and $40 \mu \mathrm{m}$ in diameter. Under SEM, iron oxides, titanium oxides, and phosphate minerals are easily distinguished as bright phases. Phosphate minerals, most with significant amounts of iron in EDS spectra (Fig. 8A), are easily discriminated by a distinctive tabular shape. Iron oxides were identified and differentiated from titanium oxides with EDS and could not be more specifically identified.

The surface texture of iron oxide grains can be either smooth (Fig. 8E) or rough (Fig. 8F). Some grains have an incomplete replacement of a preexisting mineral with iron oxide (Fig. 8D, no.1; 8E). Iron oxide replacement phases are truncated in transported clasts (Fig. 8B, no. 2). The backscatter image in Fig. 8F has been specially adjusted to view the details of a typical bright-phase iron oxide grain. This grain highlights a rare interparticle sub-micron porosity or sponge-like texture in the iron oxide grains.

Picard (1965) suggested the red pigment originated post-compaction as iron oxides were "expelled" from pore spaces. The crystalline iron oxide grains pre-dating compaction (Fig 8C, no. 1 and 2), indicating they are detrital and not a post-compaction growth. Grains also have close and sutured grain boundaries (Fig. 8 D, no.2). The detailed example in Figure 8F highlights the abraded edges and that the crystal pre-dated a blocky calcite cement.

\section{Interpretations}

Detrital iron oxide grains are interpreted to have originated from either direct precipitation from an aqueous solution at the surface or to be fragments of iron oxide cement and concretions forming near the surface that was exposed and eroded. The micro-porous surface texture of grains could be the result of the biological mediation of iron oxide precipitation. The partial replacement of grains with iron oxide is interpreted to have occurred before deposition and could have 

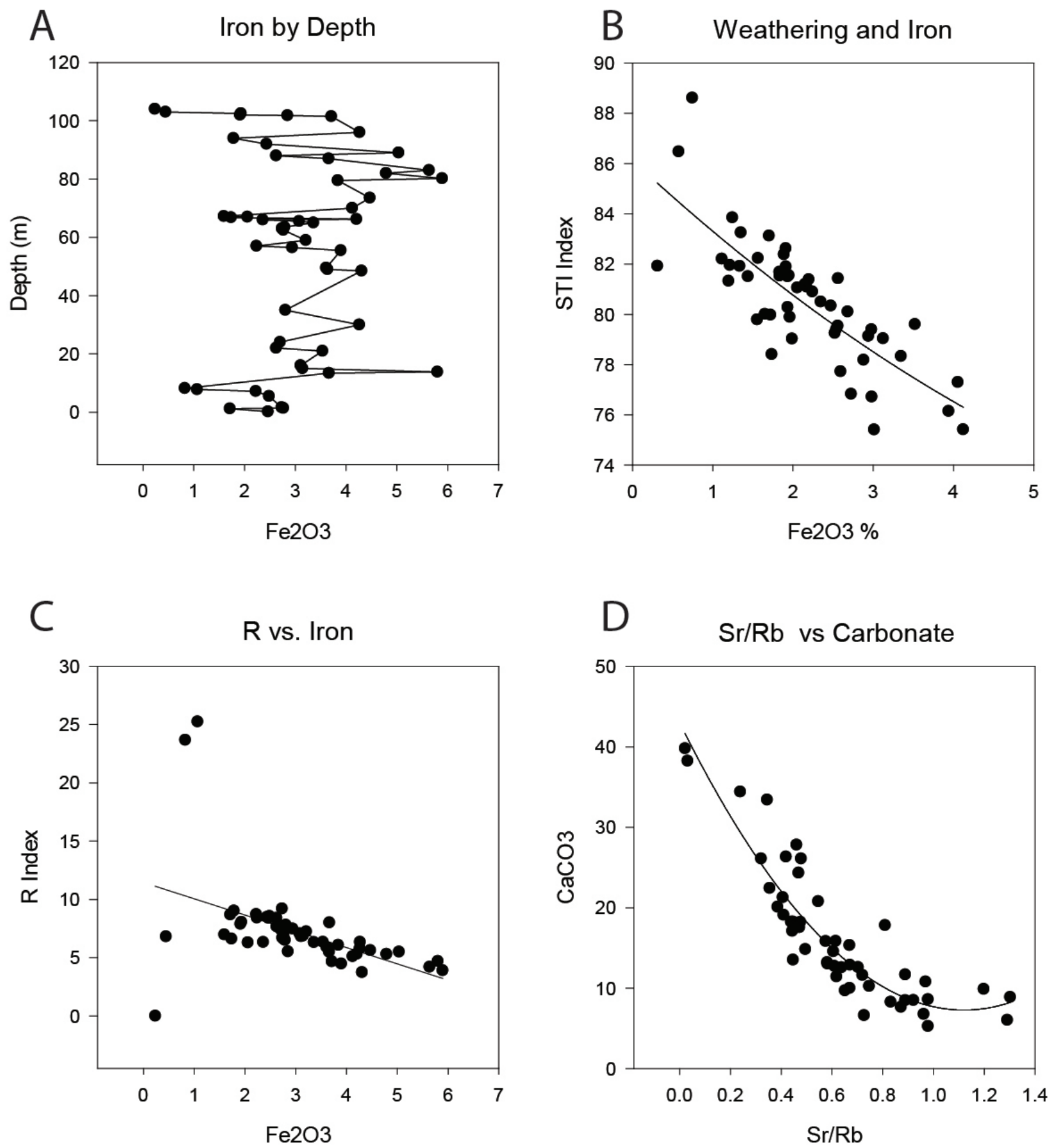

Fig. 5: Example XRF geochemical data from 52 samples from the Will Hill locality. By convention, XRF data is reported in $\mathrm{Fe} 2 \mathrm{O} 3$ and should not infer the iron oxidization state. (A) Plotted by depth showing variations in $\mathrm{Fe} 2 \mathrm{O} 3$ from $0.24 \%$ to $5.89 \%$ with no pattern in total iron by depth. (B) Total iron compared to the STI weathering index (de Jayawardena and Izawa, 1994) showing an increase in iron with increasing weathering. (C) Total iron compared to the $R$ weathering index (Ruxton, 1968) showing increasing iron content with weathering. (D) Comparison of carbonate to the $\mathrm{Sr} / \mathrm{Rb}$ value, demonstrating that the percentage of carbonate controls the $\mathrm{Sr} / \mathrm{Rb}$ ratio. Carbonate is as post-depositional cement, indicating that the use of Sr based weathering or isotopic analysis is counterindicated. 
been iron oxide cement or concretions. The physical abrasion on grain surfaces indicates iron oxide formation before transportation and deposition.

\section{Iron Oxide Grain Coatings}

\section{Descriptions}

Iron oxide coating has been observed as thin, sub-micron iron staining, and as thick abraded coatings. Thin sub-micron iron-oxide coatings appear as bright rims around well rounded to subrounded quartz grains. The rim is brighter than expected from edge effects and can be mapped as iron-rich (Fig. 9). Coated rims are associated with bright iron-oxide spots on quartz grains. It was difficult to distinguish the iron-oxide rims from edge effects, but a few were identified and mapped. In thin sections (Fig. 6), many grains have an orange-red coloration related to thin iron oxide coatings. However, the use of a field-emission SEM would be required to investigate the coatings at the sub-micron scale required.

Thickly coated grains are common, nearly ubiquitous in SEM images (Fig. 10). Coatings have maximum thicknesses between $2 \mu \mathrm{m}$ and $4 \mu \mathrm{m}$ of iron oxide. Surface topography observed by combined BSE-SE (BSE 3D) images is a high relief bright phase coating partially covering the base grain. Base grains have been identified as partially altered feldspars, quartz, and clay aggregates. Coatings have been abraded, usually as a scalloped groove or with a plucked appearance. In cross-section, iron oxide coatings appear as incomplete replacement of an original grain by iron oxide. Grains that are partially replaced by iron oxide are well-rounded, detrital grains with the iron oxide as uneven replacement texture (Fig. 8B) or as a dominant phase with inclusions of the original grain (Fig. 8E). Grains with crystalline or replacement textures have either well-rounded or abraded surfaces.

\section{Interpretations}

Iron oxide grain coatings most likely formed before deposition. The genesis of the thin iron coatings on clay grains required further investigation. They match descriptions of reddening by grain impact during eolian transport (El-Baz, 1986). Thick iron-oxide coatings, on the other, had originated before deposition. Thick coatings most likely originated where near-surface geochemistry promoted the rapid precipitation of iron oxide cement, such as in and near acid saline lakes

(Benison, 1997; Benison et al., 2007; Bowen et al., 2008). The thick coatings on grains may have 

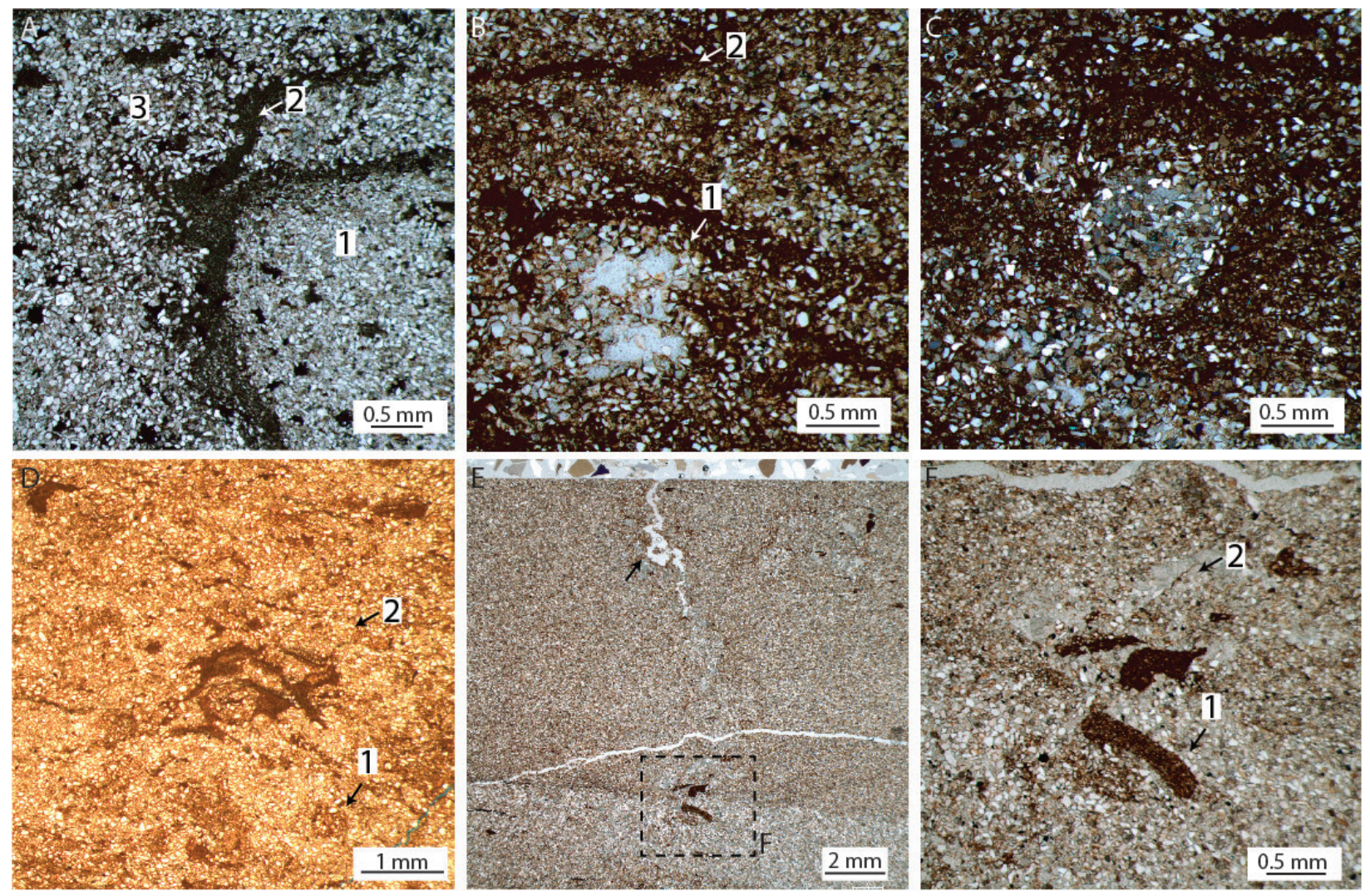

Fig. 6: Thin section photomicrographs from the Red Peak Formation. (A) Plane polar light photomicrograph of in-situ pedogenic aggregate. Well-packed siltstone aggregate (no. 1) is encircled by iron-rich clays (no. 2). Grains outside the aggregate (no. 3) are in ferruginous and non-ferruginous clay coatings with some cement. (B) Plane polar light photomicrograph of detail of blocky, poor-filling, calcite, and dolomite cement (no. 1) and ferruginous (no. 2) zones. (C) Cross polar light photomicrograph of root cast filled with cemented coarse sediment and surrounded by ferruginous clay matrix. (D) Plane polar light photomicrograph of siltstone with bioturbated mixing of the sediment (no. 1). Areas forming a network of angular ferruginous clays (no. 2) can be cracking or roots where pore space allows the infiltration of finer sediments and clays. (E) Plane polar light photomicrograph of siltstone with cement-filled burrow (arrow). (F) Detail of rip-ups (no.1) and calcite cement (no. 2) from the previous image. Note the textural inversion with large sub-rounded to rounded grains and small angular to sub-angular grains. 
been either vadose zone or phreatic zone cement or concretions. They were exposed and eroded, and the iron oxide coatings were abraded during transportation.

\section{Clay Coatings and Matrix}

\section{Descriptions}

Clay mineral coatings occur on the surface of voids, grains, around aggregates, and fill voids (Fig. 6, 11, 12). Clay coatings around grains (Fig. 11) are thin, from sub-micron to $3 \mu \mathrm{m}$ in thickness, microlaminated clay layers distinct from the surrounding clay matric. Figure 11 shows an example of clay coating around a grain in combining BSE and SEM 3D images with accompanying EDS maps. The clay coating can be seen between the compacted grains in both the BSE-3D composite image and the iron and element maps. Iron levels are elevated above the background around the grain and between the linear compacted grain surfaces, indicating iron enrichment occurred before compaction remove the grain surface from fluid interactions.

Clay coatings around aggregates (Fig. 6A, B) are dark red (2.5 YR 3/4) under plane-polarized transmitted light in the thin section. Clays are microlaminated coatings up to $1 \mathrm{~mm}$ thick comprised of oriented mid-sized clay particles and small detrital grains of quartz and feldspars (Fig. 12). The relative abundance of iron in clay matrix (Fig. 11D, 12G5) is highest around iron-rich grains and around detrital iron oxide particles, a diffusion of iron from source grains into the surrounding matrix. Soil aggregates form as spherical or ellipsoidal agglomerations (peds) of either courser or finer material from the surrounding matrix surrounded by clay coatings (cutans) and circumgranular cracking (Fig. 6A, B; Fig. 12B, C, D). Peds become rip-ups (Fig. 6E, F; 12A), providing clay and oxidized iron source from beds that have undergone pedogenesis to overlying beds.

Clay pore filling from illuviation occurs outside the context of ped development. Clay pore fills (Fig. 6D) are dark red (2.5 YR 3/4), non-lamented, and irregularly shaped networks with pointed termination. Unlike rip-ups, they do not have well-defined boundaries. Many void-filling clays occur around sediment or cement-filled features (Fig. 6B, No.2), likely roots.

Clay matrix between grains and void fill clay matrix in siltstones is uneven and ranges from a slight reddening between well-packed silt-sized grains (e.g., Fig. 6D) to ubiquitous thick dark red 

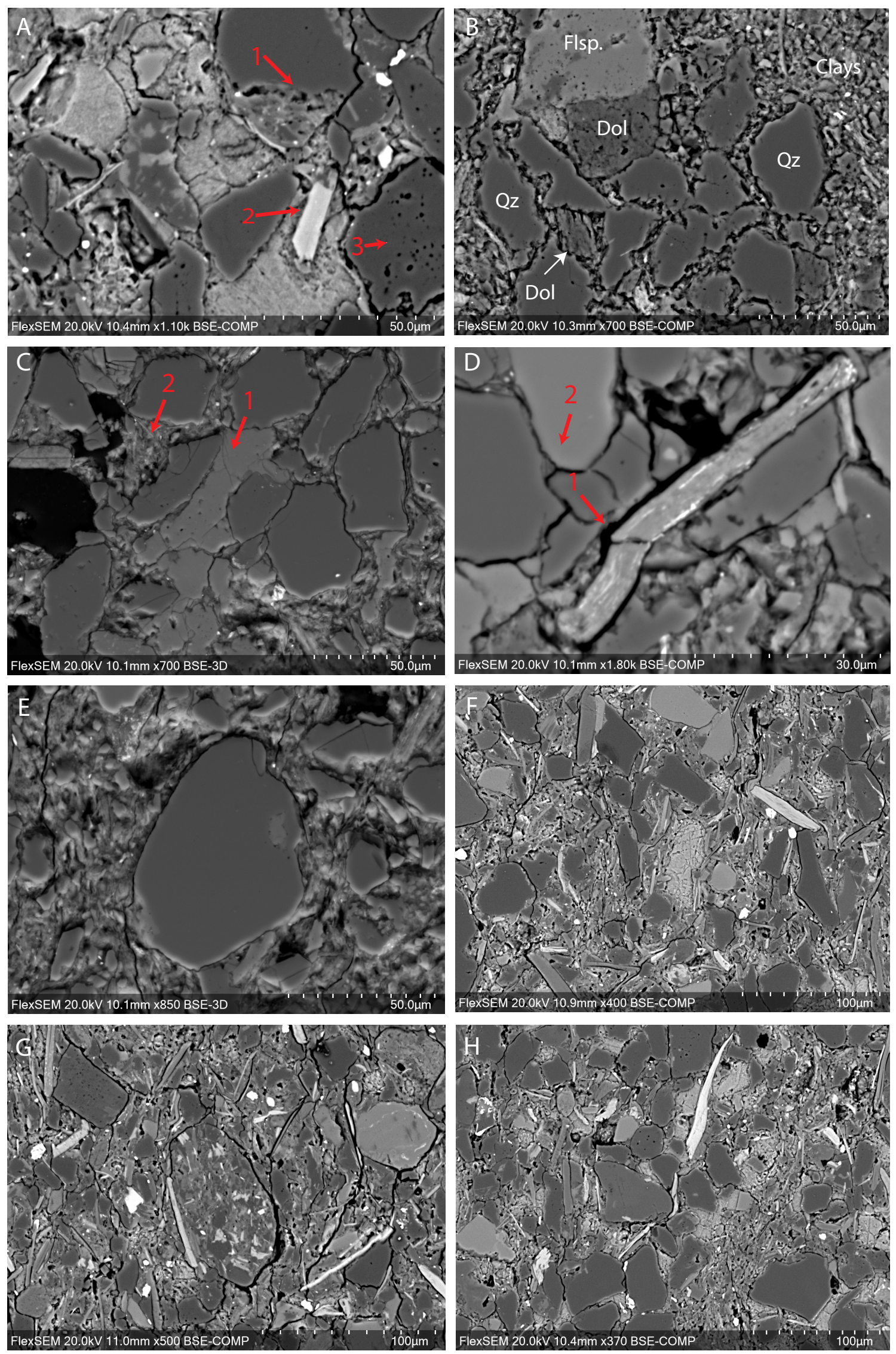
Fig. 7: SEM backscatter electron images of the Red Peak Formation showing examples of grain details and sediment texture. (A) Quartz, feldspars, and lithic fragments in a calcite cement. Authigenic replacement of quartz (no. 1), secondary chlorite grains (no. 2), and dissolution features all suggest a complex diagenetic history. (B) An example is compaction and recrystallization. Grains are compacted to the point of grain boundary deformation, perhaps with pressure dissolution. Grain edges are etched into a scalloped pattern from dissolution. Dolomite rhombs and authigenic dolomite replacement are common. (C) Detail of calcite cement (no. 1) and clay matrix (no. 2). (D) Detrital micas have broken (no. 1) in a highly compacted siltstone (no. 2). (E) Sub-rounded silt-sized quartz grain with smaller angular to sub-angular quartz grains in a clay matrix. (F) Detrital grains with original pore space preserved with cement and clay in-filling. $(G)$ Large sub-rounded lithic grain. (H) Long and broken mica in compacted siltstone with clay matrix.

(2.5 YR 3/4) matrix (e.g., Fig. 6C). Although viable thin sections from mudstones were unsuccessful, thick-section was made and polished carefully using long-duration low-weight polishing like the method used for EBSD. SEM images of mudstones (e.g., Fig. 12B, E) are mostly mudsized clay matrix with some quartz from thick sections. Elemental mapping (Fig. $12 \mathrm{G}$ ) shows a mixed clay mineral matrix with aluminum, magnesium, and iron.

Two chemical index of weathering indices were calculated from XRF data. Ruxton's (1968) R index is a simple comparison of silica to aluminum where it is assumed that silica loss correlates with total element loss while sesquioxides remain, and uses $\mathrm{Al}_{2} \mathrm{O}_{3}$ as a proxy for all sesquioxides. Higher degrees of weathering is indicated by lower $\mathrm{R}$ values from 0 to 30, with the Red Peak ranging from 0.23 to 23, with most values between 3 and 9 (Fig. 5C). Total iron content increases with decreasing R-value. de Jayawardena and Izawa's (1994) STI (Silica Titanium Index) incorporates titanium allows for more sesquioxides. The Red Peak Formation STI ranges from 75 to 88 , with values closer to 90 being less weathered (Fig. 5B). Iron also tracks with the STI with higher concentrations of iron correlating with more weathered rocks.

\section{Interpretation}

Most of the red pigment in the Red Peak Formation is contributed by the red clay mineral matrix, red coatings around grains or aggregates comprised of clay-minerals, and red void filling clay cement. The sediment must have been deposited with some red color, as is evident from the abundant detrital iron oxides grains, clasts cemented by iron oxide cement, and thickly coated iron oxide coatings. It is possible that most quartz grains entered the system with thin red coatings. Thickly coated grains, iron oxide detrital grains, and thin iron oxide coatings on quartz offered 

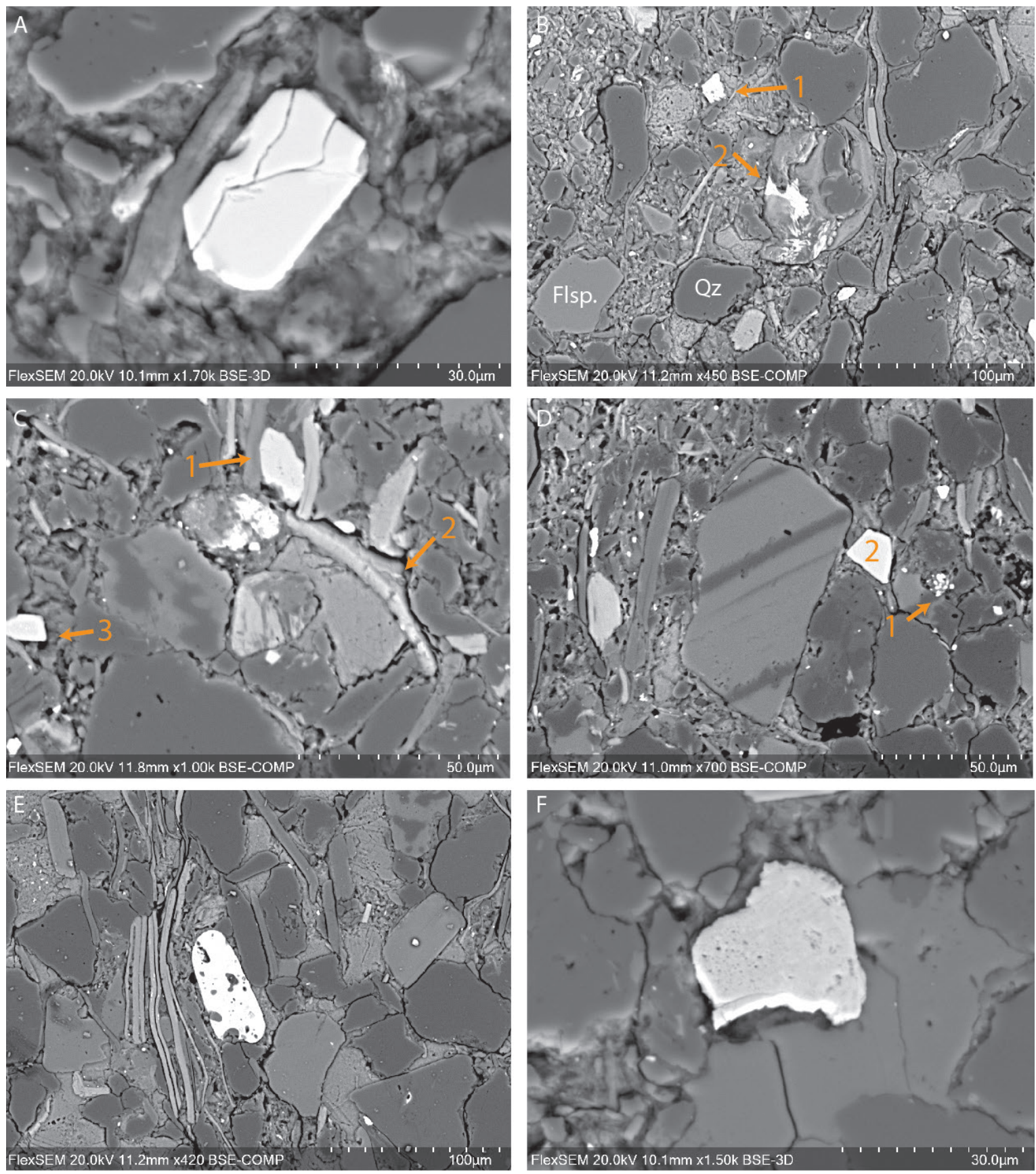

Fig. 8: SEM backscatter electron image examples of detrital iron oxides, identified as bright phases, and confirmed with EDS (A) A tabular iron oxide grain with minor ablation. Likely formed as authigenic iron minerals in saline lakes spatially proximal to the location of the deposition. (B) Typical siltstone example with angular detrital iron oxide (no. 1) and a well-rounded intraformational clast with iron oxide cement. (C) detrital iron oxide (no. 1) compacting a broken mica (no. 2). Detrital titanium oxide (no. 3) is also common. (D) Small iron oxide grain with a "speckle" texture could be an agglomeration of iron nanoparticles or incomplete replacement by iron oxide. (E) Well-rounded iron oxide grain showing incomplete replacement of an original grain by iron oxide. $(F)$ Detail of iron oxide grain at $1500 X$ with contrast optimized shows an intergranular porosity related to microbial mediation of iron oxide precipitation. 
oxidized iron sources. Those iron and iron sources in minerals such as biotite, pyroxenes, and amphibole were exposed to acid groundwater. The iron was freed through dissolution, and then hydrolysis and precipitation of iron oxides occurred, which were incorporated into authigenic clay minerals. This reddening most likely occurred before burial and compaction of the sediment, as the red matrix is present around most compacted grains, and iron-rich clay grain coatings can be visualized between even closely compacted grains.

Red clay coatings of aggregates occurred during pedogenesis as hot-cool cycles or wet-dry cycles formed a granular texture and opened circumgranular cracks and cracks that reach the surface. Illuviation and authigenic clay formation resulted in micro-laminated circumgranular cutans that incorporated iron. Clays the fill void spaces also resulted from alluvium and authigenic clay formation. That voids were filled with mud-sized iron-rich alluvium, indicating significant dustfall events contributing to reactive iron and contributing to soil formation and reddening.

\section{DISCUSSION}

Red Pigment in the Red Peak Formation is Related to the Environment of Deposition

The reddening of Red Peak sediment resulted from three overlapping processes: (1) formation of sub-micron thick iron coatings on grains during eolian transport; (2) formation of thick iron-oxide coatings and precipitation of iron oxide grains from acidic brines as groundwater or surface
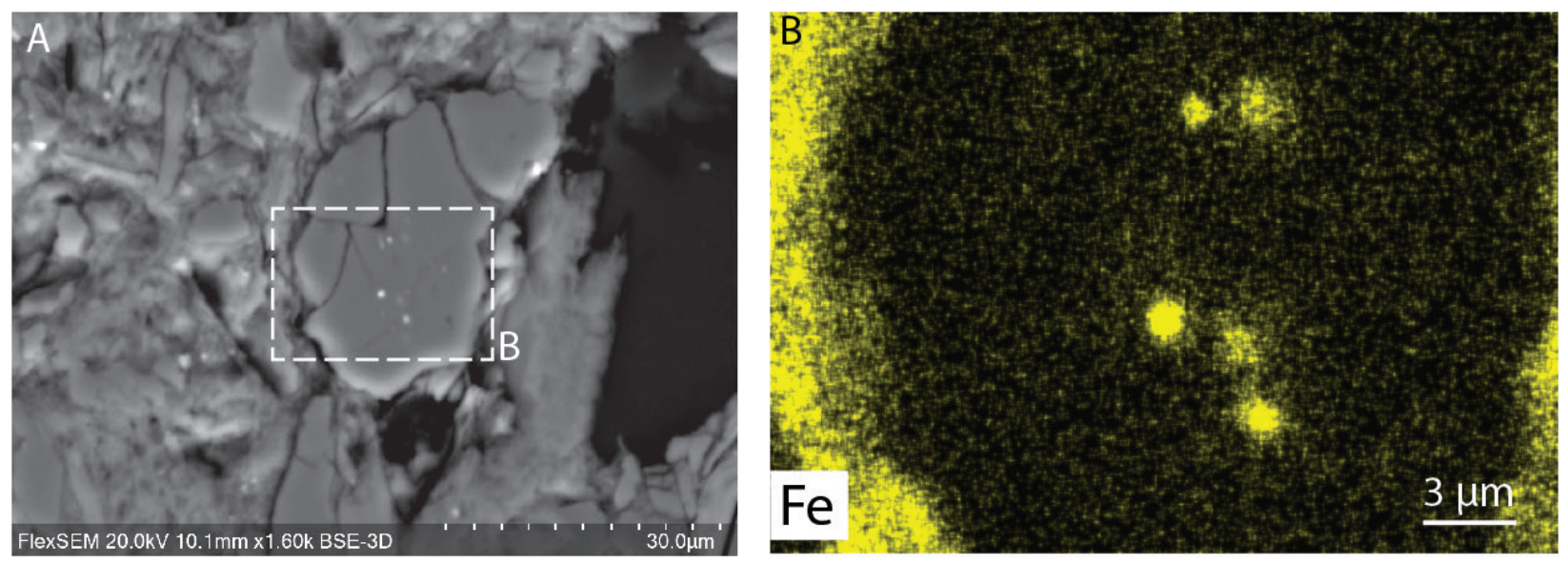

Fig.9: Thin iron oxide coating on a broken quartz grain. (A) SEM combination secondary electron and backscatter electron image (BSE-3D) at $1600 X$ magnification Note the lack of a bright rim but bright spots on the grain surface. (B) EDS map showing a $1 \mu \mathrm{m}$ to $2 \mu \mathrm{m}$ thick iron oxide rim and iron spots. The iron rim is smeared because of a cut through the grain's edge and is not part of the clay matrix. This rim and spots are little the result of abrasion and pitting during eolian transport. 

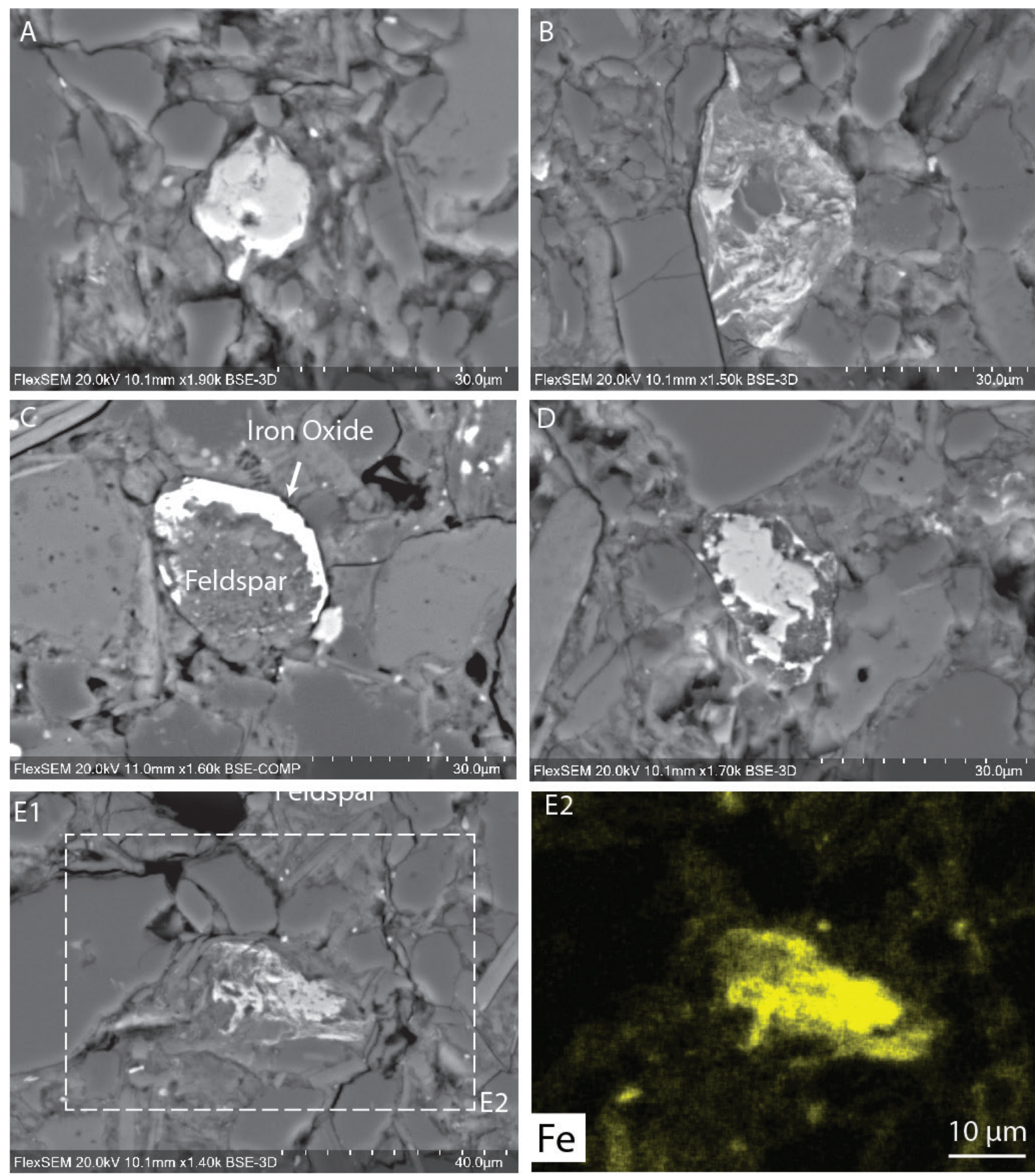

Fig 10: Examples of thick iron oxide coatings with evidence of abrasions. (A) 1900X combined backscatter and secondary electron detail of a very small $(9 \mu \mathrm{m})$ coated grain in a clay matrix. (B) $1500 X$ combined backscatter and secondary electron detail of highly abraded quartz grain. (C) $1600 X$ backscatter electron image showing a cross-section through a coated feldspar grain. (D) 17010X backscatter electron and secondary electron image of an iron-coated grain with the possible dissolution of iron oxide coatings. (E1) $1400 X$ backscatter electron and secondary electron image of a highly compacted and abraded grain with an iron oxide coating and (E2) EDS elemental map of this grain. 
water, and (3) soil reddening from the incorporation of $\mathrm{Fe}^{3+}$ nanoparticles during the formation of authigenic clays as part of soil formation (Fig 13, 14). The Red Peak Formation's pervasive red color results from pedogenic processes occurring in an oxygenated groundwater regime. It is likely the originally deposited sediment was already red due to the transported iron oxide coated grains, iron oxide grains, and intraformational rip-up clasts. Those coatings, grains, and rip-up clasts provided additional iron sources for incorporation into the clays, occurring before burial and compaction (Fig. 15).

It is well established that microcrystalline iron oxide and iron oxyhydroxide phases such as hematite, ferrihydrite, goethite, and lepidocrocite form an iron coating around silica grains at the sediment-groundwater interface, particularly in acidic groundwater (Rusch et al., 2010; Schwertmann and Taylor, 2018). Highly acidic systems are known to precipitate iron oxide coatings, cement, and concentrations directly. For example, iron oxide chemical sediments have been observed precipitating from acid saline lake water, and iron oxide cement and concretions have been documented growing from shallow acid saline groundwaters in mudflats in Western Australia (Benison et al., 2007) (Bowen et al., 2008). Also, iron oxide grain coatings are ubiquitous in acid mine drainage (Fernández-Remolar et al., 2004).

During early pedogenic alteration, iron is sourced from chemical weathering of rock-forming minerals such as hornblende and biotite. This occurs below the water table when oxidization and electrostatic interaction with free protons (acidity) break $\mathrm{Fe}^{2+}$ from rock-forming minerals. Interactions with oxygenated near-surface groundwater results in rapid oxidization to $\mathrm{Fe}^{3+}$ and precipitation of hydrated iron oxide particles or iron oxides only a few hundred angstroms across, and are incorporated into clays as they form (Allen and Fanning, 1983; Schindler and Hochella, 2015; Schwertmann and Taylor, 2018).

In the Red Peak Formation, thick iron coatings of grains occurred before deposition, as the thickest coatings (e.g., Fig. 16D) show evidence of mechanical abrasion, perhaps from long-distance transportation by wind or water (Fig. 14). Thin ( $>1 \mu \mathrm{m}$ ) elemental iron coatings of silica (e.g., Fig 16G) is similar to iron coatings from eolian desert environs (Walker, 1967b; Robert L. Folk, 1976; El-Baz, 1986). Sub-micron iron coatings completely coating grains occur in unconsolidated wind-blown sediment before deposition. Clay coatings (Fig. 6, 11) and a clay matrix (Fig. 12) with high iron content likely formed in-situ shortly post-deposition and certainly pre-compaction or cementation. Most fine clay groundmasses are indistinct and poorly formed blocky mud-sized clay minerals with high iron content, likely formed through the in-situ weathering of predecessor detrital minerals. Also, cracks and void spaces were filled with fine-grained red sediments, likely 
because of the translocation of wind-blown dust. The infiltration of iron-rich fine-grained sediment and the contributions of iron oxide coatings and detrital grains all contributed to the availability of iron for reddening during pedogenesis.

\section{The Red Pigment is Not Related to Burial and Diagenesis}

The Red Peak Formation's red pigment can be attributed to both detrital sources of iron oxide and red pigment formation during pedogenesis. Thick iron oxide coatings and detrital iron oxide grains have surface abrasion that indicates transportation after forming the iron oxide. The red pigment associated with clays can be attributed to soil formation processes. Elemental maps show that iron diffuses through the clay matrix originating from iron-rich minerals, grains with thick iron oxide coatings, and detrital iron oxide grains. Furthermore, the iron was present in clay coatings around grains before compaction and is still present between compacted grains. If the reddening occurred after compaction, fluids would have been unlikely to oxidize between compacted grains.

\section{Soil Features Give the Red Peak Distinctive Features}

Soil features like a granular texture and iron-oxide incorporating clay form with prolonged near-surface exposure of the sediment profile to oxygenated groundwater in regions with cycling between hot and cold or wet and dry. As part of soil formation, primary minerals chemically alter to secondary minerals, and eventually into the most "resistant" mineral state dominated by resistant minerals such as zircon and rutile, quartz, and kaolinite with sesquioxides (Buol and Eswaran, 1999). Long-term exposure at the surface imparts the unique textures and colors, as oxygenated near-surface aqueous solutions are required for the transformation of $\mathrm{Fe}^{2+}$ to $\mathrm{Fe}^{3+}$ and incorporation of the resulting iron oxide nanoparticles into the crystal lattice of secondary and tertiary minerals as (Buol and Eswaran, 1999; Marcelino et al., 2018; Schwertmann and Taylor, 2018).

Weathering indices are fraught with complications when applied to rocks that have undergone multiple generations of alterations (Fig. 15). Most weathering indices use either strontium or sodium in calculations. The EDXRF method did not collect sodium. Strontium methods were inappropriate as the strontium rubidium value is correlated to the percentage of calcite cement (Fig. 5A), a post-depositional product. The R and STI indexes are simple and do not account for alumina's mobility (Price and Velbel, 2003), but can be calculated without the problematic strontium or sodium. This method offers a first approximation of iron concentration's relationship 

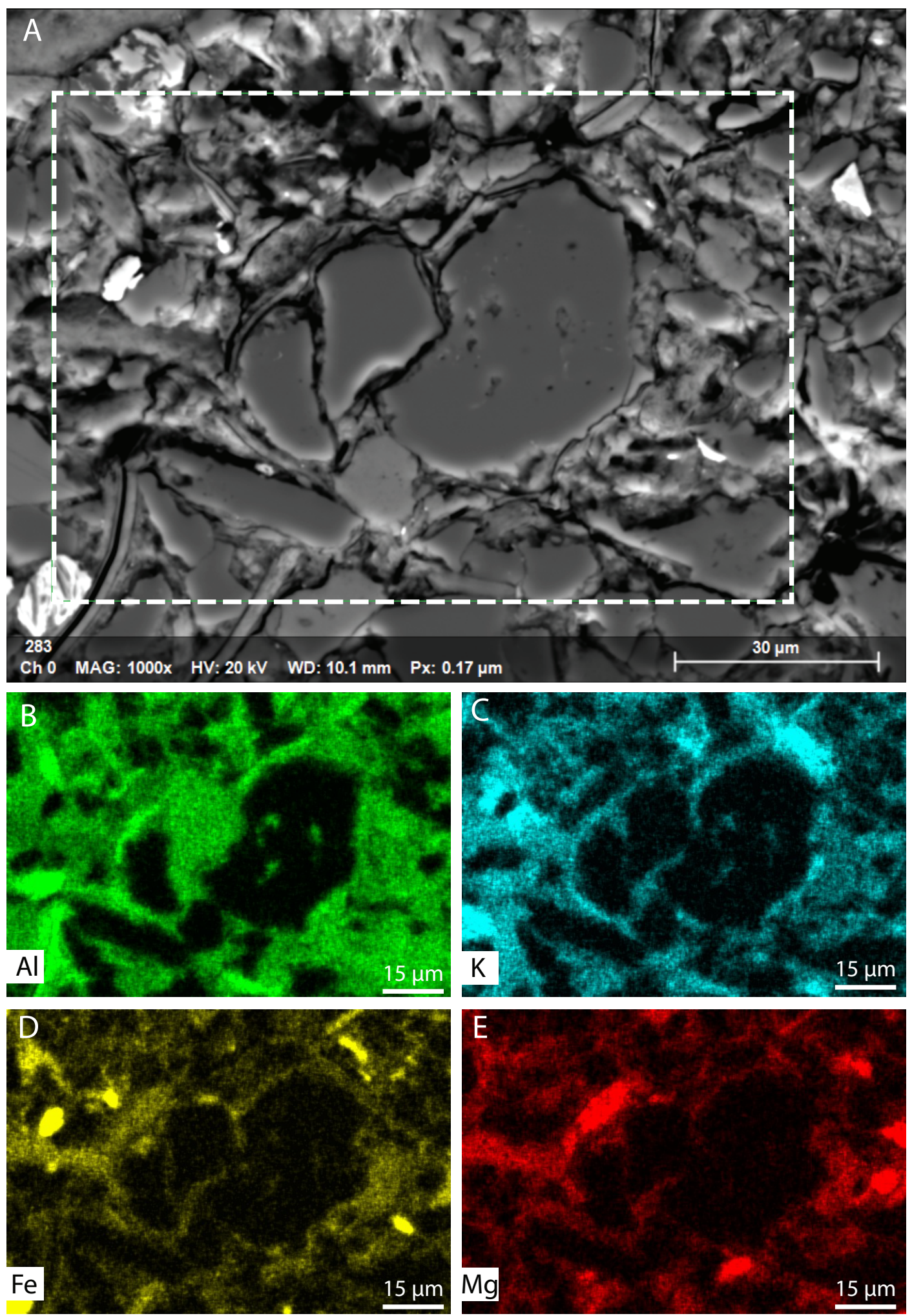

Fig. 11: Example of iron-rich clay coatings around a quartz grain. (A) 1000X backscatter electron and secondary electron image of clay coatings. Elemental maps of $(B)$ aluminum, $(C)$ potassium, (D) iron, and (E) magnesium. 

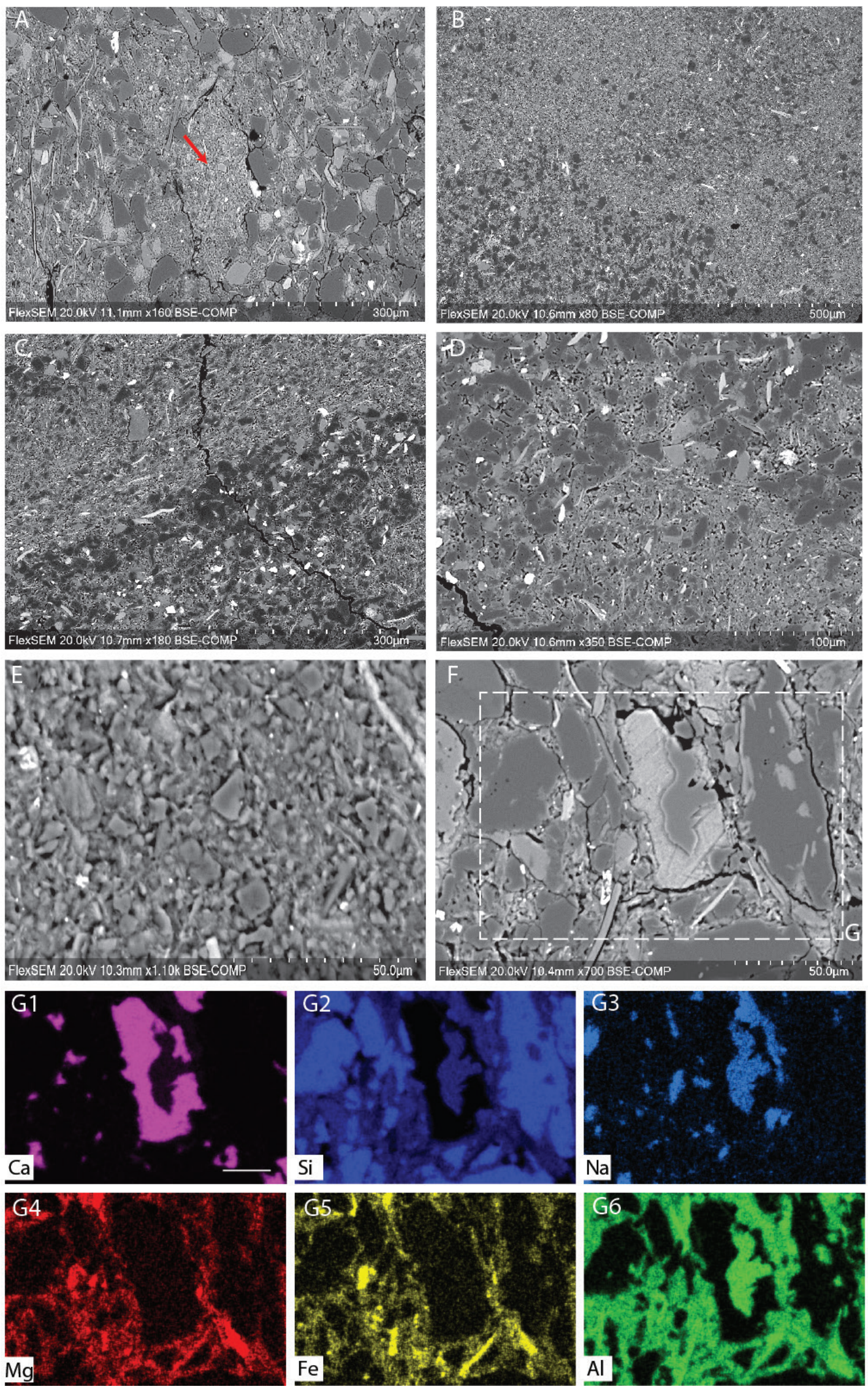
Fig 12: SEM backscatter electron and EDS examples of textures resulting from soil formation processes. (A) soil aggregate (arrow) transported and deposited in siltstone as a rip-up clast. Rip-ups contribute a major source of ferruginous clays to siltstone beds. (B) In-situ pedogenic aggregates with weak grain size zonation and abundant clays. $(C)$ Highly developed zonation in an in-situ pedogenic aggregate and alignment of mica and platy clays. The large grain in the clay-rich area is large authigenic chlorite. (D) Detail of clay-filled burrow. (E) Detail of clay matrix. (F) Typical grain and clay matrix in siltstone and accompanying elemental maps of (G1) calcium, (G2) silica, (G3) sodium, (G4) magnesium, (G5) iron, and (G6) aluminum. Elemental maps show that the highest iron concentrations are in detrital iron oxide grains, micas, and other rock-forming minerals (e.g., hornblende). Iron is disseminated unevenly in clays, concentrated around the sources.

to weathering. Both indices demonstrate that total iron concentration increases with the degree of weathering (Fig. 5B-C). Outliers are samples with either high gypsum content or anomalously high carbonate content and low iron directly below the Alcova Limestone (Fig. 5D). The direct correlation between iron and the degree of weathering is most likely due to the depletion of silica and the relative enrichment of iron or possibly the enrichment of highly weathered horizons in iron. This association of total iron with a higher weathering index is consistent with soil formation in arid and hot environments where the process of desilication and clays occurs in oxygenated interstitial water above and below a groundwater table that varies widely with the season.

Some degree of landscape stability and oxygenated soil pores and groundwater allowed the oxidation of soil iron, while wet-dry or hot-cold cycles promoted the granular texture. Thus, pedogenic processes resulted in both the bright red color and the laterally continuous horizontal bedding characteristic of the Red Peak Formation. The lack of deeply rooted plants and the related lack of overland flow channelization reinforced the overprinting of soils as the dominant process preserved in the rock record. The cross-cutting of sedimentary features by soil-originated red pigment, noted by Picard (1965), is a natural consequence of formation in the soil; soil features develop in orientation to the paleo-surface, not the depositional feature. Reduction associated with root features post-dates reddening of sediment, further reinforcing that the red color is an early feature related to near-surface processes.

\section{Implications for the Formation of Red Beds}

Two competing climates were emphasized by Walker (1967b, 1967a, 1974) for the formation of red beds: tropical/humid or arid. However, he largely dismissed the contribution of eroded red soils. In the Red Peak Formation, evidence suggests that contributions from transported iron enhanced reddening, but the majority of reddening occurred as in-situ pedogenesis. Saline 

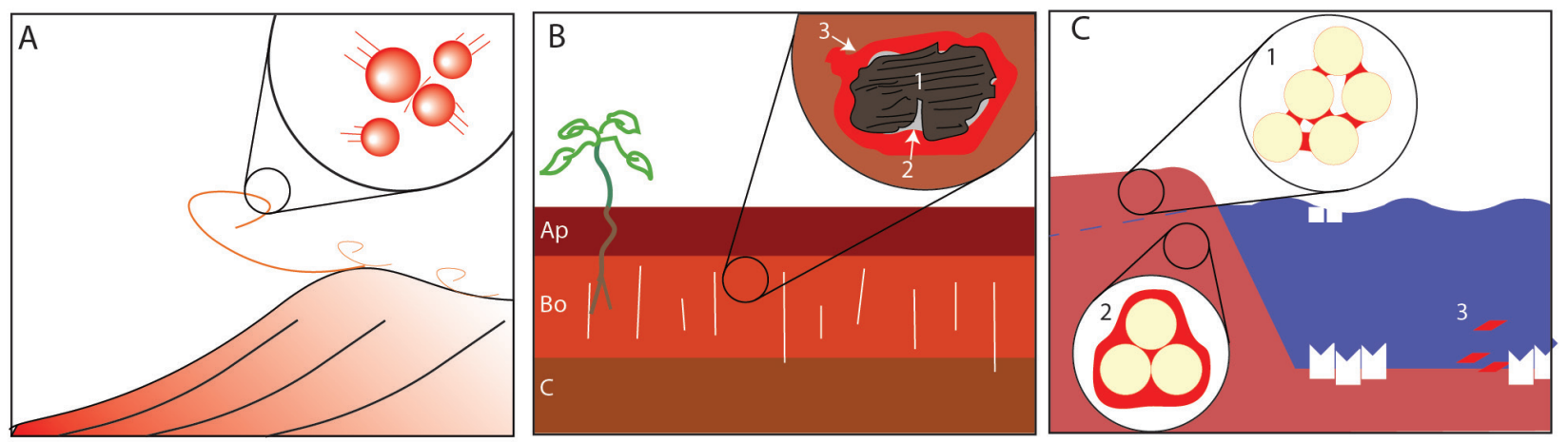

Fig. 13: Red pigment formation at or near Earth's surface. (A) In eolian systems, the impact of grains in the atmosphere can cause reddening, and the impact transfers nanometer-thick coatings of red clays suspended in the air with the grains. (B) Iron-rich minerals (no. 1) in originated soils break down into authigenic clays (no. 2) that can incorporate nanometer-sized iron oxide particles into their crystal lattice. Over time the entire soil horizon will turn red from even a minor amount of clay. (C) Acid saline lakes and associated groundwater systems precipitate iron as vadose zone cement (no.1), grain-coating cement below the water table (no. 2) that can eventually become concretions, and as precipitation of iron minerals in lake water. 


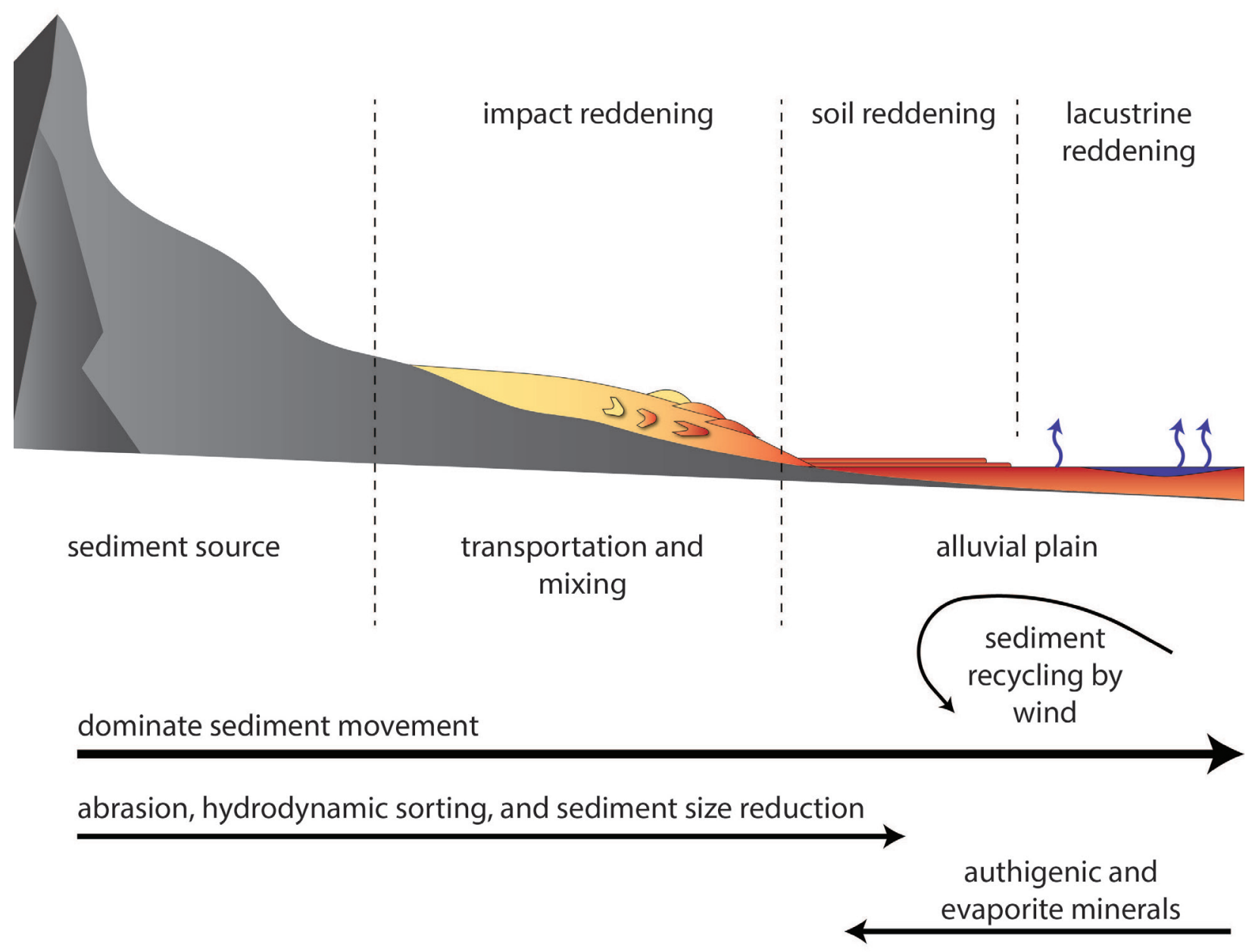

Fig. 14: Schematic diagram showing sediment transport and reddening. Sediment originates in highlands, where it is weathered and eroded. During transportation, sediment is mixed, and some will be reddened through impact reddening. On the alluvial plane, reddening occurs in soils and lacustrine settings. Wind and flooding events can reactivate and redistribute sediment on the alluvial plain, particularly during intense desiccation periods. 

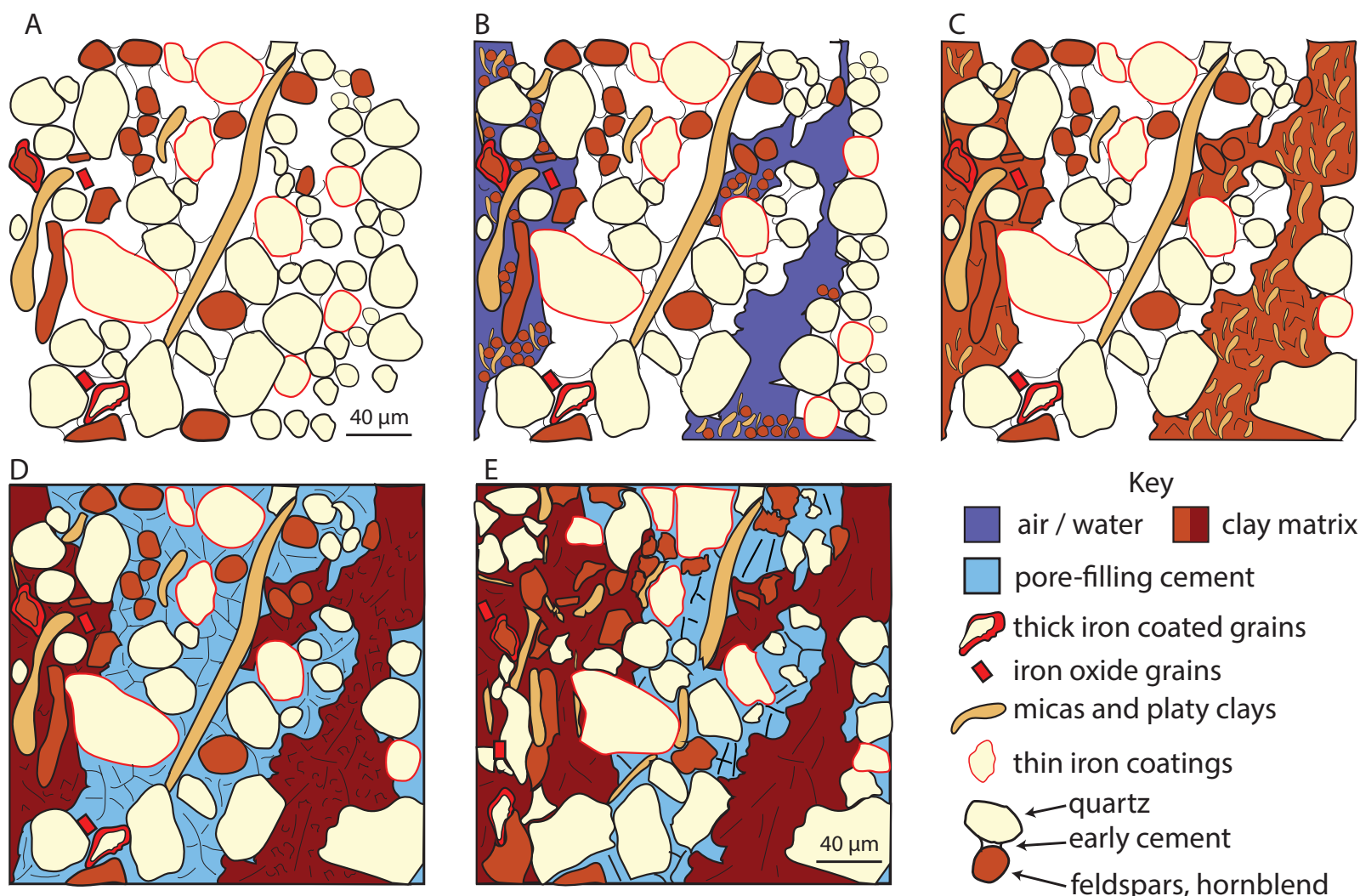

Key

air / water $\square$ clay matrix

$\square$ pore-filling cement

thick iron coated grains

$\checkmark$ iron oxide grains

$\neg$ micas and platy clays

thin iron coatings

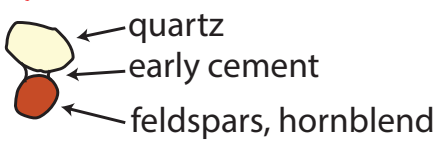

Fig. 15: Schematic post-depositional paragenesis diagram. Rocks are deposited as siltstone (A) that are chemically immature but physically mature deposited in flash flooding events or blowing wind. Iron is present in the system from rock-forming detrital minerals such (e.g., hornblendes, micas, pyroxenes), preexisting thin and thick iron-oxide coatings, and detrital iron oxide crystals. (B) Near-surface seasonal or diurnal wetting and drying and heating and cooling processes cause shrink-swell cracks and weathering of minerals to occur during soil formation. Cracks exposed to the surface are subject to infiltration of small particles from the atmosphere, translocation of sediment with the soil profile occurs through root action, burrowing, and gravity settling. Early pendant cement, possibly form gypsum, carbonate, or evaporates form. (C) As time passes in sediment exposed in the near-surface rock-forming minerals break down into clays. The clays incorporate iron nanoparticles and turn red or orange. (D) Below the water table, blocky cement forms, filling pore space. The profile is compacted as some early cement is dissolved or replaced. Under some conditions, the etching or dissolution of grains occurs. Weathering and breakdown of minerals continue. Near-surface, groundwater is originated, and reddening may continue. The breakdown of organic matter causes localized reduction around roots at the water-air interface. (E) Burial and compaction destroy the remaining porosity. Dolomite replaces some calcite cement and mineral grains. Secondary minerals (e.g., large chlorite grains) grow. 
groundwater enables high soil moisture content, even in very hot and dry conditions. Long-distance eolian transport of sediment imparted a fine red pigment to the grain surface. Acidic saline environments maintained acidic oxygenated sediment moisture and provided a catalyst for accelerated chemical weathering, imparting thick iron-oxide coatings and perhaps clay coatings. Revisiting Walker's (1967a) original criteria within the context of soil formation, all of the initial criteria for red bed formation were widespread during the Permian and Triassic. Ferric soil formation was enabled due to high temperatures, long-term landscape stability, and sufficient yet well-drained soil moisture. The proper pore groundwater is low $\mathrm{pH}$, high $\mathrm{eH}$, and originated conditions must exist and persist. The role of temperature in iron soil formation is controversial and likely dependent on the Eh and $\mathrm{pH}$ regime.

There is no conflict between the formation of red soils and dry climate. With evaporite minerals such as gypsum and subsurface halite, the Red Peak Formation was deposited in an arid climate. A long period of extreme water chemistries and relative tectonic quiescence of Pangea's midcontinent during the Permian and Triassic Periods would have established ideal conditions for the widespread formation of iron-rick soils, even in dry conditions. Soil reddening would have been enhanced by the availability of reactive iron introduced from the eolian deposition of fine ironrich dust and previously oxidized sediments formed in acid saline lacustrine systems. This series of positive feedback loops favoring soils' reddening resulted in the global accumulation of red beds around during the Permian-Triassic.

\section{CONCLUSIONS}

In the Red Peak Formation, in-situ near-surface pedogenic processes resulted in the preponderance of reddening. Some red coloration was likely inherited in the form of detrital iron oxides and iron oxide coatings. Specifically, the iron oxide occurred as (1) detrital iron oxide grains and transported grains partially replaced by iron oxide; $(2)$ thin $(<3 \mu \mathrm{m})$ coatings on quartz and thick ablated coatings on grains of any mineralogy; and (3) in clay matrix cement formed during pedogenesis as clay coatings of grains and aggerates, void filling clay cement, and clay matrix. Although observation of the forms of iron oxide in the Red Peak Formation is largely concurrence with Picard (1965), the sedimentary texture is taken into account to conclude reddening occurred at or near the surface. 
The red color of the Red Peak Formation was extant at the time of deposition and enhanced by pedogenic processes at or near the surface. Thickly coated iron oxide grains likely originated in acidic oxygenated groundwater, likely associated with acid saline lakes. Coated grains were transported and ablated before deposition. Sub-micron iron oxide coatings on grains originated during eolian sediment transport. Clay coatings of grains and aggregates, void filling clays, and an iron-rich clay matrix surrounding grains develop as part of pedogenesis, enhancing preexisting red color. The overlapping causes of red color indicate pervasive oxidizing and acidic environmental conditions.

\section{REFERENCES}

Allen, B.L., and Fanning, D.S., 1983, Chapter 6: composition and soil genesis, in Developments in soil science, Elsevier Ltd, v. 11, p. 141-192, doi:10.1016/S0166-2481(08)70601-9.

Andeskie, A.S., Benison, K.C., Eichenlaub, L.A., and Raine, R., 2018, Acid-saline-lake systems of the Triassic Mercia Mudstone Group, County Antrim, Northern Ireland: Journal of Sedimentary Research, v. 88, p. 385-398, doi:10.2110/jsr.2018.14.

Baars, D.L., 1961, Permian system of Colorado Plateau: AAPG Bulletin, v. 46, p. 149-218.

Banham, S.G., and Mountney, N.P., 2013, Controls on fluvial sedimentary architecture and sediment-fill state in salt-walled mini-basins: Triassic Moenkopi Formation, Salt Anticline Region, SE Utah, USA: Basin Research, v. 25, p. 709-737, doi:10.1111/bre.12022.

Benison, K.C., 1997, Acid water deposition and diagenesis in Permian red bed-hosted evaporites, midcontinent, United States of America: [unpublished Ph. D. thesis]: University of Kansas.

Benison, K.C., Bowen, B.B., Oboh-Ikuenobe, F.E., Jagniecki, E.A., LaClair, D.A., Story, S.L., Mormile, M.R., and Hong, B.-Y., 2007, Sedimentology of acid saline lakes in southern Western Australia: newly described processes and products of an extreme environment: Journal of Sedimentary Research, v. 77, p. 366-388, doi:10.2110/jsr.2007.038.

Benison, C.K., and Goldstein, H.R., 2001, Evaporites and siliciclastics of the Permian Nippewalla Group of Kansas, USA: a case for non-marine deposition in saline lakes and saline pans: Sedimentology, v. 48, p. 165-188, doi:https://doi.org/10.1046/j.1365-3091.2001.00362.x.

Benison, K.C., and Goldstein, R.H., 2002, Recognizing acid lakes and groundwaters in the rock record: Sedimentary Geology, v. 151, p. 177-185, doi:10.1016/S0037-0738(02)00155-0.

Benison, K.C., Goldstein, R.H., Wopenka, B., Burruss, R.C., and Pasteris, J.D., 1998, Extremely acid Permian lakes and ground waters in North America: Nature, v. 392, p. 911-914, doi:10.1038/31917. 
Blakey, R.C., 1990, Stratigraphy and geologic history of Pennsylvanian and Permian rocks, Mogollon Rim region, central Arizona and vicinity: Geological Society of America Bulletin, v. 102, p. 1189-1217, doi:10.1130/0016-7606(1990)102<1189:SAGHOP>2.3.CO;2.

Blakey, R.C., Peterson, F., and Kocurek, G., 1988, Synthesis of late Paleozoic and Mesozoic eolian deposits of the Western Interior of the United States: Sedimentary Geology, v. 56, p. 3-125, doi:10.1016/0037-0738(88)90050-4.

Blowes, D.W., Ptacek, C.J., Jambor, J.L., and Weisener, C.G., 2003, The geochemistry of acid mine drainage: Environmental Geochemistry, v. 9, p. 149-204.

Bowen, B.B., Benison, K.C., Oboh-Ikuenobe, F.E., Story, S., and Mormile, M.R., 2008, Active hematite concretion formation in modern acid saline lake sediments, Lake Brown, Western Australia: Earth and Planetary Science Letters, v. 268, p. 52-63, doi:https://doi. org/10.1016/j.epsl.2007.12.023.

Bowen, B.B., Benison, K.C., Story, S., Grotzinger, J., and Milliken, R., 2012, Early diagenesis by modern acid brines in Western Australia and implications for the history of sedimentary modification on Mars: Mars Sedimentology, SEPM Special Publication, v. 102, p. 229-252.

Braddock, W.A., 1963, Geology of the Jewel Cave SW Quadrangle Custer County, South Dakota: US Geological Survey Bulletin, v. 1063, p. 1-58.

Brill, K.G., 1963, Permo-Pennsylvanian Stratigraphy of Western Colorado Plateau and Eastern Great Basin Regions: Geological Society of America Bulletin, v. 74, p. 307-330, doi:10.1130/0016-7606(1963)74[307:PSOWCP]2.0.CO;2.

Brinkman, R., 1970, Ferrolysis, a hydromorphic soil forming process: Geoderma, v. 3, p. 199206, doi:10.1016/0016-7061(70)90019-4.

Brookfield, M.E., 2004, The enigma of fine-grained alluvial basin fills: The Permo-Triassic (Cumbrian Coastal and Sherwood Sandstone Groups) of the Solway Basin, NW England and SW Scotland: International Journal of Earth Sciences, v. 93, p. 282-296, doi:10.1007/ s00531-004-0381-z.

Buol, S.W., and Eswaran, H., 1999, Oxisols: Advances in Agronomy, v. 68, p. 151-195, doi:10.1016/S0065-2113(08)60845-7.

Burk, C.A., Thomas, H.D., Burke, C.A., Thomas, H.D., Burk, C.A., and Thomas, H.D., 1956, The Goose Egg Formation (Permo-Triassic) of eastern Wyoming: Report of Investagations. US Government Printing Office, Washington, DC.

Butcher, G.S., Kendall, A.C., Boyce, A.J., Millar, I.L., Andrews, J.E., Dennis, P.F., and Grasby, S., 2012, Age determination of the Lower Watrous red-beds of the Williston Basin, Saskatchewan, Canada: Bulletin of Canadian Petroleum Geology, v. 60, p. 227-238, doi:10.2113/gscpgbull.60.4.227.

Crowley, P.D., Reiners, P.W., Reuter, J.M., and Kaye, G.D., 2002, Laramide exhumation of the Bighorn Mountains, Wyoming: an apatite (U-Th)/He thermochronology study: Geology, v. 30, p. 27-30.

Cumming, A.D., 1956, The Watrous strata in Saskatchewan: in Christopher J. E., First International Williston Basin Symposium October 9, 10, 11, 12, 1956: North Dakota Geological Society \& Saskatchewan Geological Society, p. 165-169. 
Darton, N.H., 1906, Geology of the Bighorn Mountains: US Government Printing Office, Washington, DC.

Darton, N., 1899, Jurassic Formations of the Black Hills of South Dakota: Geological Society of America Bulletin, v. 10, p. 383-86.

Dorsey, G.E., 1926, The Origin of the Color of Red Beds: The Journal of Geology, v. 34, p. 131-143, doi:10.2307/30057891.

Dow, W.G., 1964, The Spearfish Formation in Western North Dakota: in Third International Williston Basin Symposium: Saskatchewan Museum of Natural History, Regina, Saskatchewan, September 17, 18, 19, 1964: North Dakota Geological Society \& Saskatchewan Geological Society, p. 127-131.

Dubiel, R.F., Parrish, J.T., Parrish, J.M., and Good, S.C., 1991, The Pangaean Megamonsoon: Evidence from the Upper Triassic Chinle Formation, Colorado Plateau: PALAIOS, v. 6, p. 347-370, doi:10.2307/3514963.

Dubiel, R.F., and Smoot, J.P., 1994, Criteria for interpreting paleoclimate from red beds - a tool for Pangean reconstructions: p. 295-310.

El-Baz, F., 1986, On the reddening of quartz grains in dune sand, in Physics of desertification, Springer Netherlands, p. 191-209, doi:10.1007/978-94-009-4388-9_14.

El-Baz, F., 1978, The meaning of desert color in earth orbital photographs: Photogrammetric Engineering and Remote Sensing, v. 44, no.1, p. 69-75.

Fan, M., and Carrapa, B., 2014, Late Cretaceous-early Eocene Laramide uplift, exhumation, and basin subsidence in Wyoming: Crustal responses to flat slab subduction: Tectonics, v. 33, p. 509-529.

Fernández-Remolar, D. et al., 2004, The Tinto River, an extreme acidic environment under control of iron, as an analog of the Terra Meridiani hematite site of Mars: Planetary and Space Science, v. 52, p. 239-248, doi:10.1016/j.pss.2003.08.027.

Ferris, F.G., Tazaki, K., and Fyfe, W.S., 1989, Iron oxides in acid mine drainage environments and their association with bacteria: Chemical Geology, v. 74, p. 321-330.

Hayden, F. V., Society, P., and Ser, N., 1862, On the Geology and Natural History of the Upper Missouri: Transactions of the American Philosophical Society, v. 12, p. 1-218, doi:10.2307/1005249.

Van Houten, F.B., 1973, Origin of Red Beds A Review-1961-1972: Annual Review of Earth and Planetary Sciences, v. 1, p. 39-61, doi:10.1146/annurev.ea.01.050173.000351.

Jayawardena, U. de S., and Izawa, E., 1994, A new chemical index of weathering for metamorphic silicate rocks in tropical regions: A study from Sri Lanka: Engineering Geology, v. 36, p. $303-310$.

Krynine, P.D., 1935, Arkose deposits in the humid Tropics; a study of sedimentation in southern Mexico: American Journal of Science, p. 353-363.

Limarino, C.O., Césari, S.N., Spalletti, L.A., Taboada, A.C., Isbell, J.L., Geuna, S., and Gulbranson, E.L., 2014, A paleoclimatic review of southern South America during the late Paleozoic: A record from icehouse to extreme greenhouse conditions: Gondwana Research, v. 25, p. 1396-1421, doi:10.1016/j.gr.2012.12.022. 
Long, D.T., Lyons, W.B., and Hines, M.E., 2009, Influence of hydrogeology, microbiology and landscape history on the geochemistry of acid hypersaline waters, NW Victoria: Applied Geochemistry, v. 24, p. 285-296.

Mann, A.W., 1983, Hydrogeochemistry and weathering on the Yilgarn Block, Western Australia-ferrolysis and heavy metals in continental brines: Geochimica et Cosmochimica Acta, v. 47, p. 181-190, doi:10.1016/0016-7037(83)90131-X.

Marcelino, V., Schaefer, C.E.G.R., and Stoops, G., 2018, Oxic and related materials, in Interpretation of micromorphological features of soils and regoliths, Elsevier, p. 663-689, doi:10.1016/b978-0-444-63522-8.00023-1.

McKee, E., 1980, A study of global sand seas: US Geological Survey Professional Paper: US Government Printing Office, Washington DC

McKee, E.D., 1964, Problems on the recognition of arid and of hot climates of the past: Problems in paleoclimatology: Interscience Publishers, London, p. 367-377.

Murchison, R.I., 1841, First sketch of some of the principal results of a second geological survey of Russia: Philosophical Magazine Series 3, v. 19, p. 417-422, doi:10.1080/14786444108650460.

Murchison, R.I., and Harkness, R., 1864, On the Permian rocks of the north-west of England, and their extension into Scotland: Quarterly Journal of the Geological Society, v. 20, p. $144-165$.

Murchison, R.I., and Strickland, H.E., 1840, On the Upper Formations of the New Red Sandstone System in Gloucestershire, Worcestershire, and Warwickshire; showing that the Red or Saliferous Marls, including a peculiar Zone of Sandstone, represent the "Keuper" or " Marnes Irisees;" with some account: Transactions of the Geological Society of London, v. 2-5, p. 331-348, doi:10.1144/transgslb.5.2.331.

Parrish, J.T., 1993, Climate of the supercontinent Pangea: The Journal of Geology, v. 101, p. 215-233, doi:10.1086/648217.

Phillips, J.A., 1882, The red sands of the Arabian desert: Quarterly Journal of the Geological Society, v. 38, p. 110-113.

Picard, M.D., 1965, Iron oxides and fine-grained rocks of Red Peak and Crow Mountain Members, Chugwater (Triassic) Formation, Wyoming: Journal of Sedimentary Research, v. 35, p. 464-479, doi:10.1306/74D712AD-2B21-11D7-8648000102C1865D.

Price, J.R., and Velbel, M.A., 2003, Chemical weathering indices applied to weathering profiles developed on heterogeneous felsic metamorphic parent rocks: Chemical geology, v. 202, p. $397-416$.

Robert L. Folk, 1976, Reddening Of Desert Sands: Simpson Desert, N. T., Australia: SEPM Journal of Sedimentary Research, v. Vol. 46, p. 604-615, doi:10.1306/212f6fff-2b24-11d7$8648000102 \mathrm{c} 1865 \mathrm{~d}$.

Rowe, H., Hughes, N., and Robinson, K., 2012, The quantification and application of handheld energy-dispersive $\mathrm{x}$-ray fluorescence (ED-XRF) in mudrock chemostratigraphy and geochemistry: Chemical Geology, v. 324-325, p. 122-131, doi:10.1016/j.chemgeo.2011.12.023.

Royer, D.L., Berner, R.A., Montañez, I.P., Tabor, N.J., and Beerling, D.J., 2004, CO 2 as a pri- 
mary driver of Phanerozoic climate: GSA today, v. 14, p. 4-10.

Rusch, B., Hanna, K., and Humbert, B., 2010, Coating of quartz silica with iron oxides: Characterization and surface reactivity of iron coating phases: Colloids and Surfaces A: Physicochemical and Engineering Aspects, v. 353, p. 172-180, doi:10.1016/j.colsurfa.2009.11.009.

Ruxton, B.P., 1968, Measures of the degree of chemical weathering of rocks: The Journal of Geology, v. 76, p. 518-527.

Schindler, M., and Hochella, M.F., 2015, Soil memory in mineral surface coatings: Environmental processes recorded at the nanoscale: Geology, v. 43, p. 415-418, doi:10.1130/G36577.1.

Scholle, P.A., Peryt, T.M., and Ulmer-Scholle, D.S., 1995, The Permian of Northern Pangea (P. A. Scholle, T. M. Peryt, \& D. S. Ulmer-Scholle, Eds.): Berlin ; New York, Springer-Verlag, 3-133 p., doi:10.1 007/978-3-642-78593-1.

Schwertmann, U., and Taylor, R.M., 2018, Iron Oxides, in John Wiley \& Sons, Ltd, p. 379-438, doi:10.2136/sssabookser1.2ed.c8.

Sheldon, N.D., 2005, Do red beds indicate paleoclimatic conditions?: A Permian case study: Palaeogeography, Palaeoclimatology, Palaeoecology, v. 228, p. 305-319, doi:10.1016/j. palaeo.2005.06.009.

Soil Survey Staff, 1994, Keys to Soil Taxonomy, 2010: Soil Conservation Service, 327-328 p.

Steiner, M.B., Renne, P.R., 1996, Magnetic polarity at the end of the Permian; new insights from West Texas: Eos, Transactions, American Geophysical Union, v. 77, p. 164.

Story, S., Bowen, B.B., Benison, K.C., and Schulze, D.G., 2010, Authigenic phyllosilicates in modern acid saline lake sediments and implications for Mars: Journal of Geophysical Research, v. 115, doi:10.1029/2010JE003687.

Tabor, N.J., 2013, Wastelands of tropical Pangea: high heat in the Permian: Geology, v. 41, p. 623-624, doi:10.1130/focus052013.1.

Tabor, N.J., and Montañez, I.P., 2002, Shifts in late Paleozoic atmospheric circulation over western equatorial Pangea: Insights from pedogenic mineral $\delta 180$ compositions: Geology, v. 30, p. 1127-1130, doi:10.1130/0091-7613(2002)030<1127:SILPAC>2.0.CO;2.

Tabor, N.J., and Poulsen, C.J., 2008, Palaeoclimate across the Late Pennsylvanian-Early Permian tropical palaeolatitudes: a review of climate indicators, their distribution, and relation to palaeophysiographic climate factors: Palaeogeography, Palaeoclimatology, Palaeoecology, v. 268, p. 293-310, doi:10.1016/j.palaeo.2008.03.052.

Tomlinson, C.W., 1916, The Origin of Red Beds: A Study of the Conditions of Origin of the Permo-Carboniferous and Triassic Red Beds of the Western United States: The Journal of Geology, v. 24, p. 238-253, doi:10.2307/30078150.

Walker, T.R., 1967a, Color of Recent Sediments in Tropical Mexico: A Contribution to the Origin of Red Beds: Geological Society of America Bulletin, v. 78, p. 917-920, doi:10.1130/0016-7606(1967)78[917:CORSIT]2.0.CO;2.

Walker, T.R., 1967b, Formation of red beds in modern and ancient deserts: Geological Society of America Bulletin, v. 78, p. 353-368, doi:10.1130/0016-7606(1967)78[353:FORBIM]2.0. $\mathrm{CO} ; 2$. 
Walker, T.R., 1974, Formation of red beds in moist tropical climates: a hypothesis: Geological Society of America Bulletin, v. 85, p. 633-638, doi:10.1130/0016-7606(1974)85<633:FOR$\mathrm{BIM}>2.0 . \mathrm{CO} ; 2$.

Waugh, B., 1973, The Distribution and Formation of Permian-Triassic Red Beds: Bulletin of Canadian Petroleum Geology, v. 19, no. 2, 373-374., p. 678-693.

Widdowson, M., and Gunnell, Y., 1995, Lateritization, geomorphology and geodynamics of a passive continental margin: the Konkan and Kanara Coastal Lowlands of Western Peninsular India (M. Thiry \& R. Simon-Coinçon, Eds.): Blackwell Publishing Ltd., 245-274 p., doi:10.1002/9781444304190.ch10. 


\title{
CHAPTER 5
}

As submitted to the Journal of Sedimentary Research, under review

\section{THE ALCOVA LIMESTONE:}

\section{SALINE LACUSTRINE ENVIRONMENTS OF THE TRIASSIC CHUGWATER GROUP}

\author{
JONATHAN P. KNAPP ${ }^{1,2}$ and KATHLEEN C. BENISON ${ }^{1}$ \\ ${ }^{1}$ Department of Geology and Geography, West Virginia University, \\ Morgantown, West Virginia, U.S.A. 26506-6300 \\ ${ }^{2}$ Bruker Nano Analytics, Berlin, 12489, Germany \\ corresponding author: Jonathan Knapp \\ author email: Jonathan.Knapp@,bruker.com
}

keywords: Alcova, Chugwater, Triassic, lacustrine, carbonate, red beds 


\begin{abstract}
The Alcova Limestone is an anomalous thin and laterally extensive limestone unit within the Chugwater Group's thick red bed succession. The Alcova Limestone has three types of carbonate: (1) a sulfur-bearing crystalline carbonate attributed to bacterial sulfate reduction of original limestone, (2) bedded crystalline carbonate, and (3) massive crystalline carbonate. Sedimentological, stratigraphic, and geochemical observations of the Alcova Limestone strongly suggest that it was not deposited in a marine or marginal marine setting; it was a saline lake system within a larger arid continental setting. Several lines of evidence suggest the original lithology was a mixture of carbonate, gypsum, and organics. The stratal stacking pattern in the Chugwater Group contains, from bottom to top: (1) tens of $\mathrm{m}$ red beds with alternating recessive and resistant bed sets, (2) a few m of limestone, and (3) a return to red beds with less distinctive bed set patterns than the underlying ones. This occurrence of a thin limestone unit isolated within a thick succession of red beds is not an isolated case but rather a relatively common deposition pattern in Permo-Triassic rocks that requires explanation. This study's implications include a reinterpretation of Pangea's paleo-shoreline in Wyoming during the late Permian and Early Triassic, refinement of paleoclimate for western low-latitudinal Pangea, and support of a hypothesis that much of Pangea was dominated by saline lakes and red mudflats, sandflats, and paleosols.
\end{abstract}




\section{INTRODUCTION}

The Alcova Limestone is a thin $(\sim 2-3 \mathrm{~m})$, laterally-extensive carbonate unit associated with the red beds of the Triassic Chugwater Group of Wyoming. An easily identifiable unit, the Acova Limestone, correlates Permian and Triassic strata of Wyoming and surrounding states, a succession dominated by fossil-poor red sandstones and siltstones (Bower 1964; Lee 1927; Picard 1997; Pipiringos and O'Sullivan 1978). The Alcova Limestone is characterized by slightly convoluted laminations, a paucity of body or trace fossils, and laterally extensive beds. The unit has abrupt conformable contacts with underlying and overlying continental red beds.

The Alcova Limestone is an example of regional, distinctive strata: a thin limestone or gypsum unit stratigraphically isolated within terrigenous red beds and extends geographically over hundreds of square $\mathrm{km}$. Other notable examples of thin laterally extensive limestone or gypsum units within terrestrial red beds are the Jurassic-Cretaceous Codocedo Limestone Member of the Quebrada Monardes Formation in the Atacama region of Chile (Bell, 1989), the Permian Minnekahta Limestone of the Black Hills and the Williston Basin ( Benison et al. 2018; Privrasky et al. 1958; Ulmer et al. 1992), and the Triassic Lockatong Formation's limestone beds of the Newark Basin of New Jersey (El Tabakh and Schreiber 1994). These units share notable features with the Alcova Limestone, such as convoluted lamina, upward doming lamina, a paucity of fossils, and evidence of gypsum replaced by carbonate. Each represents a striking lithofacies change from the surrounding strata. The environment of deposition of these units, as well as associated hydrologic and climatic conditions, remain ambiguous.

The environment of deposition for the Alcova Limestone has been hypothesized to be a hypersaline restricted shelf due to: (1) the carbonate composition, (2) ${ }^{87} \mathrm{Sr} /{ }^{86} \mathrm{Sr}$ that overlaps with interpreted late-Early Triassic ${ }^{87} \mathrm{Sr} /{ }^{86} \mathrm{Sr}$ marine curve, (3) the presence of Corosaurus marine reptiles, and (4) tidal flat interpretations for some of the underlying red bed siliciclastics (Lovelace and Doebbert 2015; Picard 1966; Picard et al. 1969; Storrs 1991). Except for a single dissertation arguing for deposition in a large inland lake (Carini, 1964), all previous studies have used the presence of limestone as prima-facies evidence of a marine origin. Considering the widespread replacement of gypsum by carbonate minerals in similar units and the paleosol and eolian interpretations of equivalent red beds elsewhere in the mid-continent, the Alcova Limestone deposition environment remains uncertain. 
This study aims to interpret the Alcova Limestone's depositional environment, based, for the first time, on detailed sedimentologic and stratigraphic observations, supplemented with elemental analyses. Results can help interpret broader environmental conditions for the Triassic of Wyoming and similar anomalous chemical sediments within a thick succession of red beds elsewhere in the world.

\section{GEOLOGIC BACKGROUND}

\section{Challenges to Stratigraphic Resolution}

The Alcova Limestone is exposed to Larmide uplifts' flanks throughout Wyoming and southern Montana (Fig. 1). It forms a resistant unit between the Red Peak Formation's underlying red beds and the lower Chugwater Group and the overlying red beds of the upper Chugwater Group (Fig. 2). The Chugwater Group and Goose Egg Formation contain up to $300 \mathrm{~m}$ of red beds (Cavaroc and Flores 1991). The Red Peak Formation is the oldest unit of the Chugwater Group in most of its extent. This unit is called the Red Peak Member by Love (1939) and continued with modifications by McKee et al. (1959) and Tohill and Picard (1966). The Red Peak is a 45 - 70 m thick

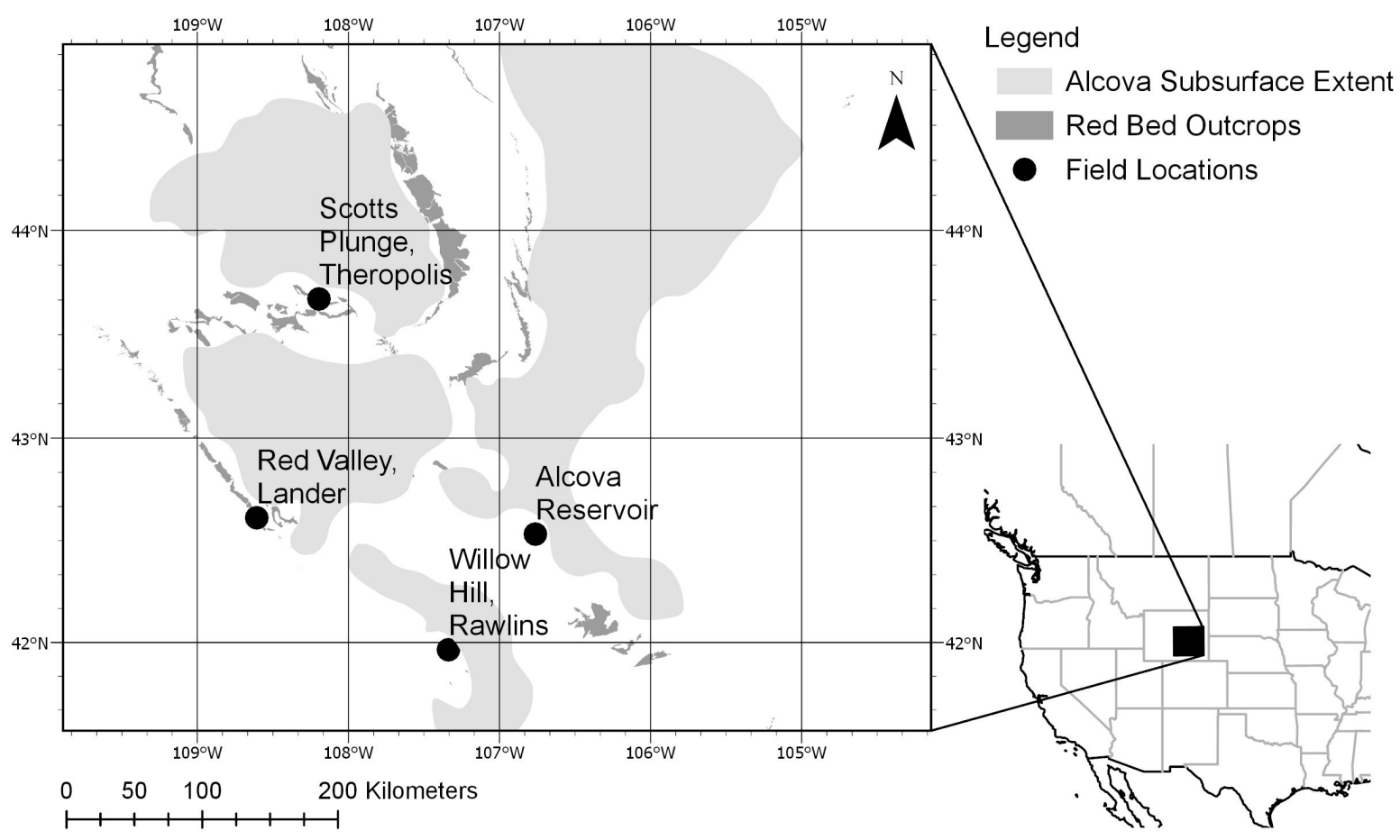

Fig. 1: Alcova limestone field locations in southeastern Wyoming. The approximate locations of four field sited described in this study are shown as black dots and labeled. The dark gray represents exposures of Permo-Triassic red beds and evaporites along the flanks of Laramide uplifts. Pale gray areas show the locations of the Alcova Limestone in the subsurface. 

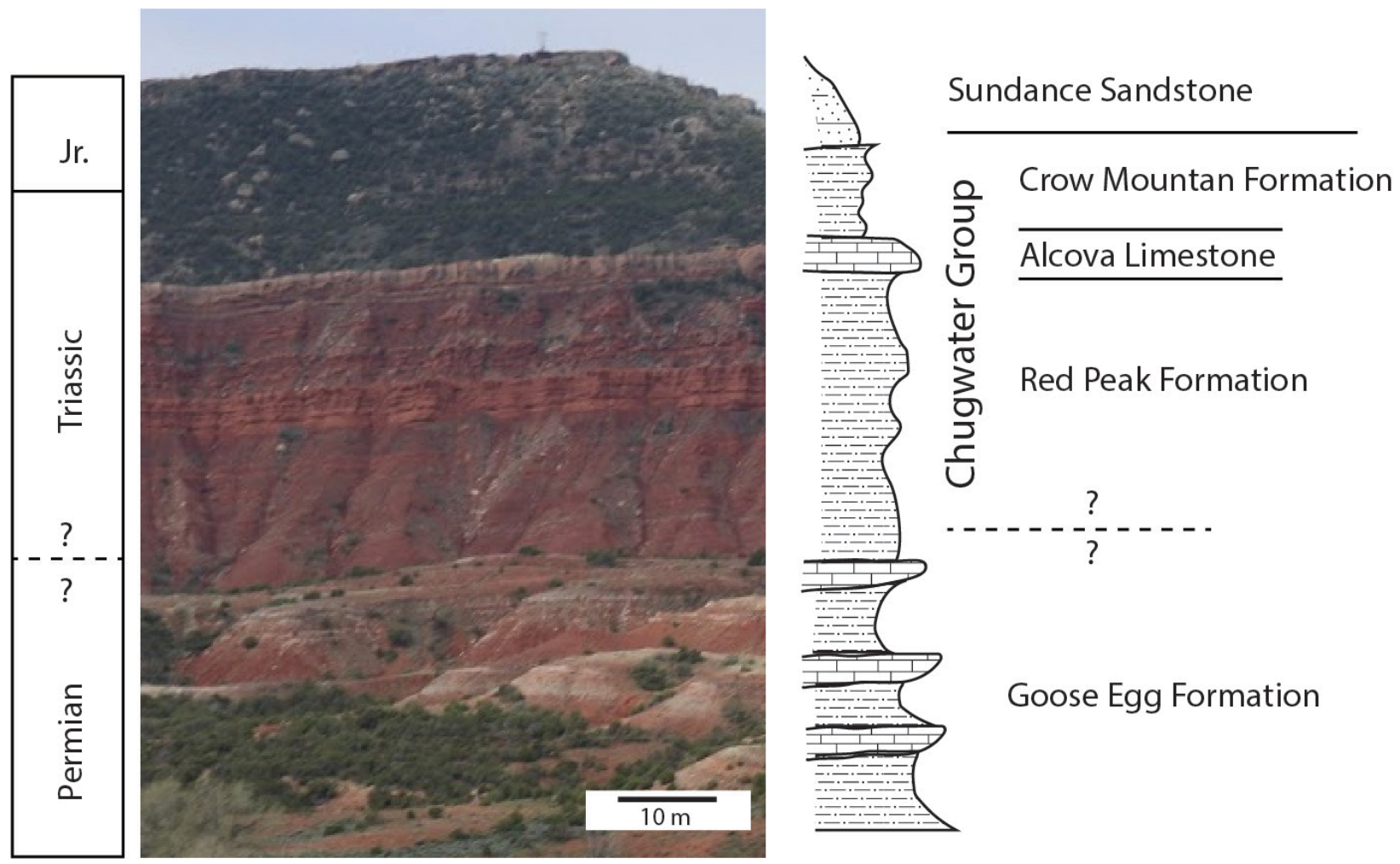

Fig. 2: Stratigraphic context of the Alcova Limestone. Photo from Bessemer Bend near Casper, Wyoming, shows the typical stratigraphic arrangement of Permian-Triassic units in central Wyoming. The exact position of the Permian-Triassic boundary cannot be firmly established here.

package of terrigenous red beds deposited in an arid to a semi-arid basin. The "rhythmic alterations" between recessive and resistant units in the Red Peak Formation have been previously attributed to sea level alternations (Picard and High 1963) due to variations in grain size.

The Alcova was originally described as a 2.4-m resistant, bedded, purplish limestone at its type locality of Alcova Dam, Natrona County, Wyoming (Lee 1927). This thin unit is present through a large part of Wyoming and northern Colorado (Tohill 1965; Lee 1927; Pipiringos and O’Sullivan 1978). Originally considered a stratigraphic member, the Alcova Limestone was raised to formation rank with the other Chugwater units and used as the primary stratigraphic linchpin for correlations throughout central Wyoming (Pipiringos 1968).

The thin Alcova's lateral extent seems anomalous, confusing as to stratigraphic rank and position. For example, Love (1948) included the Alcova Limestone's basal sandstone (terminology of this study) with the Alcova where the Limestone is present and grouping them with the Red Peak where the limestone is not present. The Alcova Limestone has been correlated to the Portneuf 
Member of the Thaynes Formation in Idaho but has been demonstrated in the subsurface to be younger (Reeside et al. 1957). It can be identified and correlated easily on electric logs (Pipiringos 1968) and picked on thousands of those logs (Fig. 1, a light grey area). However, the Alcova Limestone relationship to many other carbonates or evaporate unit is dubious, based on little more than relative stratigraphic position and similar lithology.

\section{Challenges in Age Dating}

The Alcove Limestone is stratigraphically positioned between the Red Peak Formation and the overlying Crow Mountain or Jelm Formations, indicating a Middle or Late Triassic age (Reeside et al. 1957). Fossils are of limited utility for dating the Alcova Limestone. The only distinct body fossil identified from the Alcova is Corosaurus alcovensis, a reptile with aquatic adaptation for locomotion in shallow water and apparent salt tolerance (Rieppel 1998). Corosaurus is the only North American 'Nothosauria,' a common Triassic reptile. Long-distance correlations to more readily datable horizons in the Thaynes Formation (Picard et al., 1969) are questionable due to later tectonics, the vicissitudes of log response over long distances, and contradictory evidence

presented by Reeside (1957). Lovelace and Doebbert (2015) matched Alcova Limestone ${ }^{87} \mathrm{Sr} /{ }^{86} \mathrm{Sr}$ ratios between 0.70843 and 0.70816 to a global marine seawater curve (Korte et al. 2006) and then used this to both claims a marine origin for the Alcova Limestone and reassigned its age as Early-Middle Triassic.

\section{Ambiguous Environment of Deposition}

The Alcova Limestone notably lacks obvious diagnostic features indicative of a marine or non-marine environment of deposition. Although several invertebrate fossils have been described, none are diagnostic of the depositional environment (Rieppel 1998; Storrs 1991). Corosaurus alcovensis is adapted for aquatic locomotion, leading to interpretations of near-shore deposition of the Alcova Limestone (Storrs 1991), but this fossil indicates no specific environment. Most workers have used carbonate lithology (Kummel 1954) and long-distance correlations to other carbonate units (Picard et al. 1969) to assume a marine environment of deposition. Carini (1964) argued in an unpublished thesis that desiccation cracks and ripple marks and the thickest portion in the center of the deposit indicated that the Alcova Limestone was a "lake-sea" or freshwater lake. Storrs (1991), Cavaroc and Flores (1991), and Lovelace and Doebbert (2015) used various isotopic systems to indicate a marine or restricted marine environment of deposition, a problematic proposition since both Storrs (1991) and Carini (1964) demonstrated evidence of early diagenesis, and none used measurements from unaltered, articulated invertebrate shells. 


\section{MATERIALS AND METHODS}

\section{Study Site}

This study focused on fieldwork, petrography, and elemental mapping of the Alcova Limestone. Associated red beds were described to provide a sedimentological and stratigraphic context. Although outcrops of these rocks were observed throughout much of Wyoming, this study focused on four locations: (1) the Alcova Reservoir in Alcova, (2) Willow Hill near Rawlins, (3) Scotch Plunge in Thermopolis, and (4) Red Valley near Lander (Fig. 1).

\section{Fieldwork}

Fieldwork was conducted in the summers of 2015 and 2016. Measured sections (Fig. 3) of the four locations were made by describing, at the cm scale, color, composition, sedimentary textures, sedimentary structures, fossils, and diagenetic features. Stratigraphic relationships, including bedding contacts and lateral transitions, were noted. Rocks were tested in the field with $\mathrm{HCl}$ to check for reactions that would indicate carbonate minerals. Hand samples representative of all lithologic types were collected from each section. Photography was used to document field observations.

\section{Thin Section Petrography}

Petrographic observations were made with 8 large-format $(2 \times 3$ in) and 5 small-format ( $1 \times 2$ in) thin sections. Petrographic observations were made on an Olympus SZX12 stereo microscope capable of 6.3 - 63 x magnification and equipped with transmitted, reflected, and polarized light sources. A digital camera with Spot 5 imaging software was used to document petrographic observations.

\section{X-Ray Diffraction}

To confirm the Alcova Limestone's general mineralogy and associated red bed siliciclastics, $\mathrm{X}$-ray diffraction was conducted on four powdered samples. A PANalytical X'pert Pro Cu anode $\mathrm{x}$-ray diffractometer housed in the Shared Research Facilities at West Virginia University was used. Bulk powder samples were measured for 60 seconds per degree between 10 and 90 degrees. Bulk analyses did not distinguish clay minerals quantitatively. 


\section{Elemental Mapping}

All thin section billets were analyzed with the Bruker M4 300 Tornado mapping $\mu$ XRF at Colorado School of Mines. This $\mu \mathrm{XRF}$ is equipped with two $30 \mathrm{~mm}^{2}$ silicon drift detectors and a rhodium x-ray tube with polycarpellary x-ray optics to achieve a step size of $25 \mu \mathrm{m}$. Measurements were collected under a 20 millibar vacuum with a $40 \mathrm{KeV}$ excitation energy at 200 microamps. Mapping was conducted with a line scan spacing of $100 \mu \mathrm{m}$ (equivalent to final pixel size) and a data acquisition dwell time of $20 \mathrm{~ms}$ (equivalent to a stage speed of $\sim 1.5 \mathrm{~mm} / \mathrm{s}$ ). Billets were used to ensure an appropriate thickness for x-ray information depth and eliminate thin section glass interference. The average initial relative abundance maps took between 5 and 8 hours to collect.

After data acquisition, $\mathrm{X}$-ray peaks were selected manually for each map. $\mu$ XRF maps all elements simultaneously by collecting an energy spectra from approximately $1 \mathrm{kV}$ to $50 \mathrm{kV}$. Peaks represent elements present in sufficient concentrations. A deconvolution algorithm within the M4 software resolves peak interferences and outputs net elemental abundance mass in selected elements. Quantification maps (QMaps) were created from the relative abundance maps using a standard-corrected fundamental parameter algorithm in Bruker's X-Method software. Spectra from bins of 5 x 5 pixels were combined with increasing the signal-to-noise ratio and reducing processing times to approximately 15 hours per sample.

\section{RESULTS}

This section is subdivided to organize the rocks stratigraphically, with rocks underlying the Alcova Limestone, the Red Peak Formation, and the alternating red beds and calcareous sandstone lithofacies described and interpreted first. Then, the various lithofacies of the Alcova Limestone are included. These Alcova lithofacies include (1) basal sandstone, (2) massive carbonate mudstone-wackestone, (3) wavy laminated carbonate, and (4) crinkle bedded limestone. The red beds of the Crow Mountain Formation, which overlie the Alcova Limestone, are described and 
interpreted last. An interpretation of that lithofacies immediately follows the description of each lithofacies.

\section{Red Peak Formation}

\section{Description}

The Red Peak Formation, directly below the Alcova Limestone (Fig. 2, 3), consists of up to $300 \mathrm{~m}$ of red siltstones and mudstones. A full description of this unit is beyond the scope of this paper. However, to thoroughly examine the nature of the abrupt facies transition at the Alcova Limestone base, the Red Peak must be addressed. The Red Peak Formation is known for a distinctive alternating pattern of recessive and resistant red siliciclastic strata. The alternating beds are most distinctive near the contact with the overlying Alcova Limestone (Fig 4A). All bedding is laterally continuous within a single outcrop; some beds can be traced for $\mathrm{km}$ in the outcrop. However, it is impossible to trace individual beds from outcrop to outcrop.

Recessive units in the Red Peak Formation are between 20 to $150 \mathrm{~cm}$ thick units of dark red (10R 3/6) to dusky red (10R 3/3 to 3/2) clayey siltstone and laminated clayey siltstone. Recessive beds have a ubiquitous overprint of ped development in a continuum from small blocky peds to well-developed large rounded peds. The smaller peds are most commonly found in the thinner recessive units. Relic ripple cross-laminations and planar laminations can be distinguished in some of the strata overprinted with small blocky peds. Well-developed peds are rounded with clay-rich cutans, forming darker edges along ped surfaces. Units with well-developed peds are dark reddish-brown (5YR 3/2 to 3/4), with mottled patches of pale green (GLAY1 8/2 to 6/2) silt; no relic sedimentary structures can be distinguished. Cross-cutting thin veins or "stringers" of secondary gypsum/anhydrite, isolated pods of gypsum/anhydrite crystals, and gypsum/anhydrite-filled cracks are common in all recessive beds but are not found in surrounding resistant beds. Reduction spots and discontinuous horizontal reduction bands are white (GLAY 1 8/0) to pale grey (GLAY 2 5/5PB) and cross-cut ped structures and bedding, including resistant and resistive beds. Reduction zones are commonly associated with cracks.

Resistive units are between $30 \mathrm{~cm}$ to $150 \mathrm{~cm}$ and contain one or more beds of red (10R 5/6 to $5 / 8)$ to reddish brown (2.5YR 5/3 to 5/4) siltstone with rare sandy siltstone. These resistive siltstones and sandy siltstone units have an erosional base with up to $10 \mathrm{~cm}$ of relief and grade upward into the overlying recessive units. Some resistive units have erosional tops as well as bases. These sandy siltstones have a paucity of sedimentary structures and are most commonly massive 


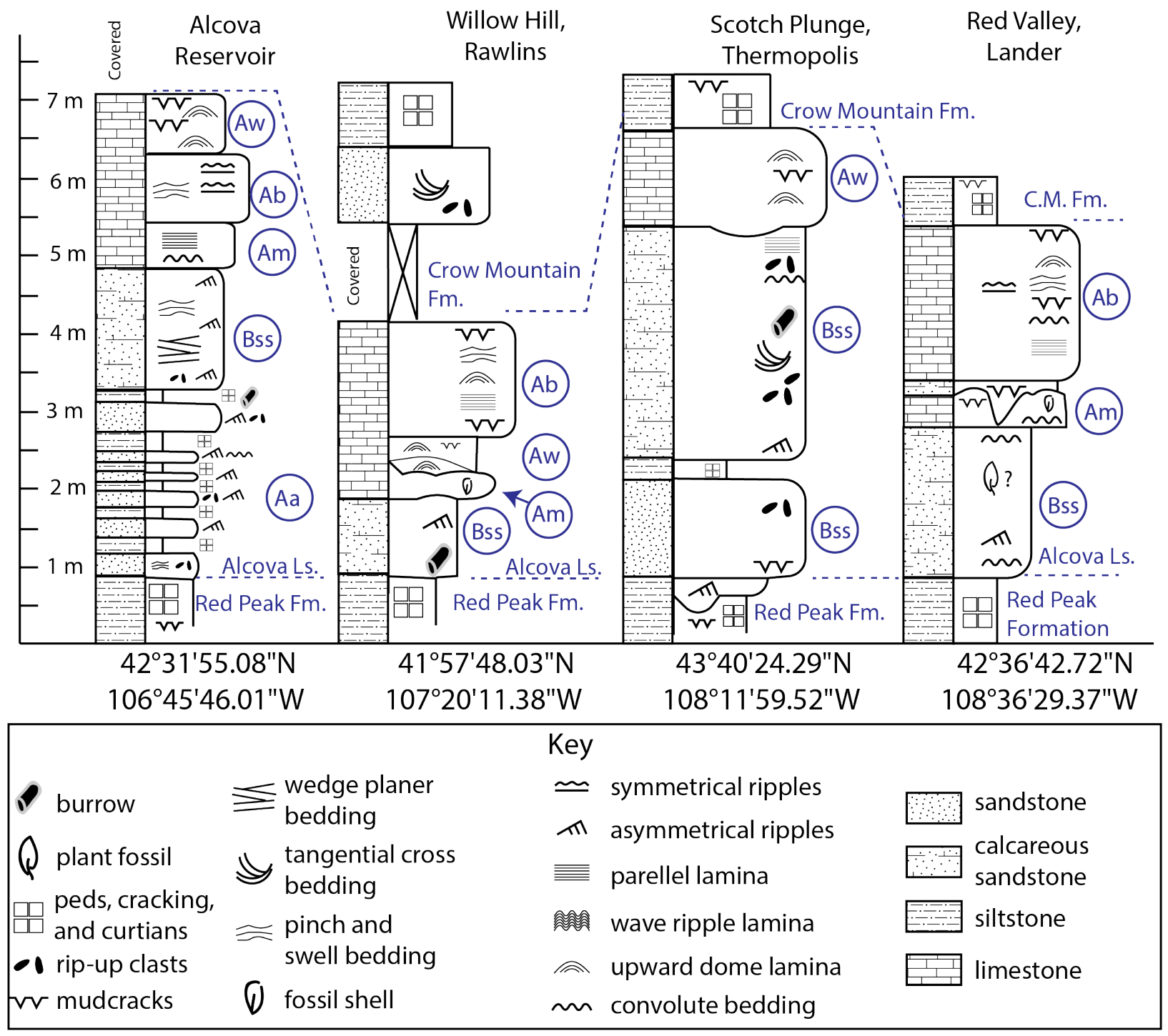

Fig. 3: Measured Sections through the Alcova Limestone with sedimentary structures and lithofacies. Locations are references in Figure 1. Lithofacies are the basal sandstone (Bss), alternating red bed, and calcareous sandstone (Aa), the massive mudstone (Am), wavy laminated carbonate $(A w)$, and crinkly bedded carbonate $(A b)$. 

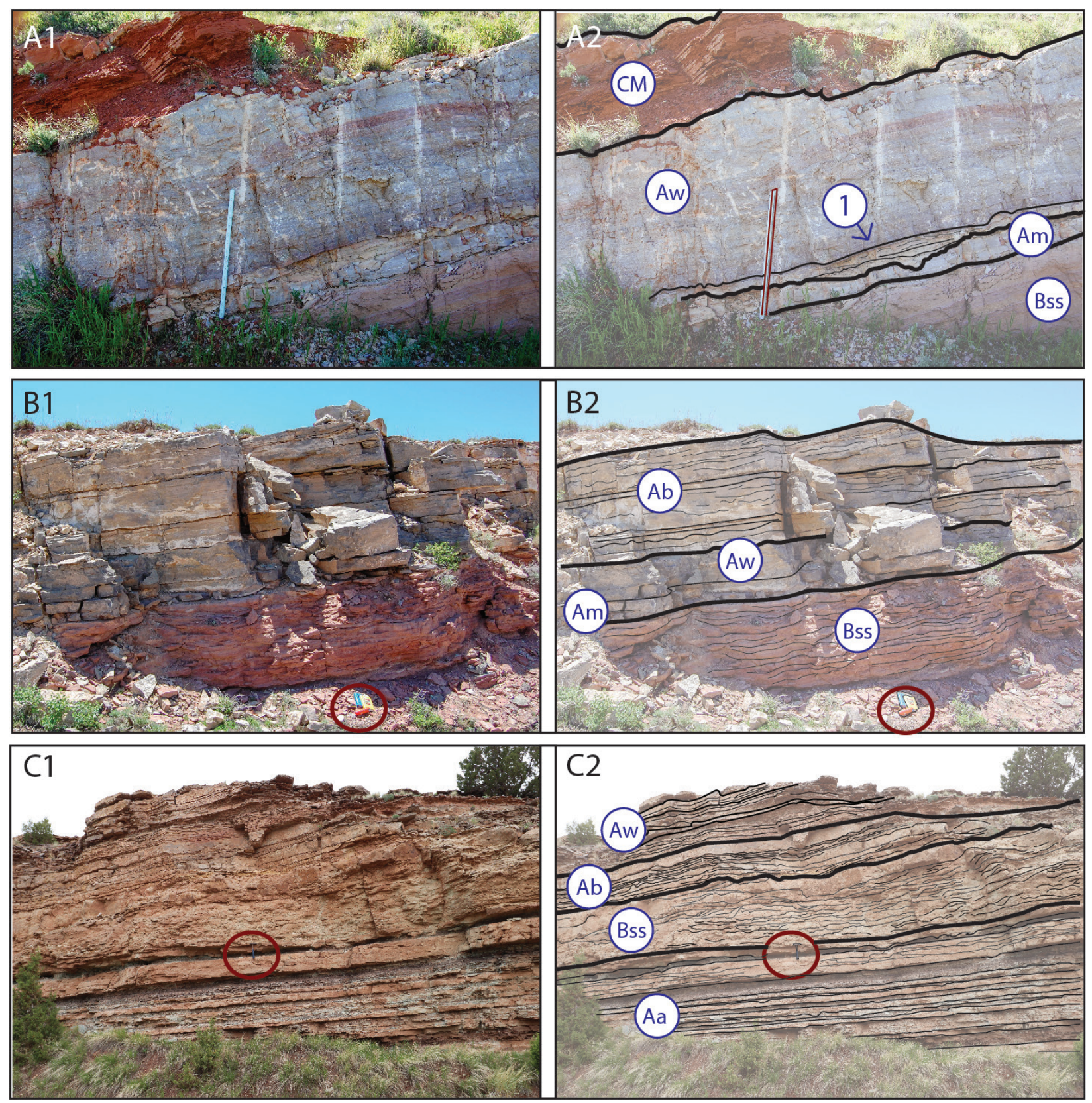

Fig. 4: The Alcova Limestone in outcrop. A1, B1, and C1 are original photos, and paired images A2, B2, and C2 are annotated to show lithofacies. A1 and A2: Red Valley locality near Lander. Note sandstone lens (in Aw) marking where a channel (point 1) eroded the underlying Am lithofacies. Meter stick for scale. B1 and B2: Willow Hill locality near Rawlins. Circled field book and hammer for scale. C1 and C2: Alcova Reservoir locality. Circled hammer for scale. Lithofacies abbreviations correspond to measured sections depicted in strat columns from Figure 3. 
with weak indications of cross-stratification or internal erosive surfaces too poorly defined for identification. However, rare internal structures can be identified. The most common sedimentary structure is current ripple cross-lamination. Ripple cross-lamina are either planar beds with tangential forests or, more rarely, swaley cross-stratification. Bedding surfaces have polygonal cracks, current ripple marks, rare sole marks, and wave ripple marks. Imbricated muddy rip-up clasts are common near the base of beds, commonly defining weak cross-stratification.

\section{Interpretations}

The recessive layers have more clay and smaller grain sizes than the resistive units, which are interpreted as a result of soil formation. The sedimentary features, which include gleying, reduction layers, peds, clay cutans, cracks, and early diagenetic gypsum/anhydrite, are all diagnostic of soil formation. Reduction features may indicate the decay of rare organic material. Soils range from weak entisols to well-developed aridisols (in the terminology of Retallack 1998) or gypsisols and protosols (in the terminology of Tabor et al. 2017). Resistant beds are consistent with formation in unconfined flow environments such as distal alluvial fans. These sheet floods deposited finegrained sediment; later, the sediment was overprinted by soil formation during quiescent periods.

The Red Peak Formation exhibits the characteristics of deposition in an arid climate. Original sedimentary structures can be identified in entisols or protosols, but soil horizons either do not develop or are not preserved. In extant environments, entisols are common in unstable environments or climatic conditions that limit soil development (Pendleton and Jenny 1945), such as periglacial environments or locations with a rapid influx of sediment. Aridsols or gypsisols are diagnostic of arid and hot environments (Retallack and McDowell 1988; Retallack 1999; Retallack and Huang 2010; Tabor et al. 2017). The combined presence of gypsum and pseudomorphs after gypsum, abundant angular cracking, blocky peds, and early calcite cement suggest that soil formation occurred in an evaporative regime. Angular blocky peds like those of the Red Peak Formation indicate intensive weathering.

In contrast, wedge-shaped aggregates, accompanied by sub-angular blocky peds and slickenplanes, likely formed by shrink-swell processes in wet climate regimes (Tabor et al. 2017) conspicuously absent in the Red Peak but are present in the underlying Goose Egg Formation and the Crow Mountain Formation above the Alcova. The Red Peak Formation has low ichnodiversity with few root traces and no identified burrows. Entisol mudstones with well-developed peds, clay cutans, current ripple lamina, and a paucity of trace fossils are consistent with a dry 
climate with occasional sheet flooding (Hasiotis et al. 2007). Therefore, the Red Peak Formation is interpreted to be a continental deposit.

\section{Alternating Red Beds and Calcareous Sandstone Lithofacies}

\section{Description}

The alternating red beds and calcareous sandstone lithofacies is a discontinuous unit below the obvious limestone at the Alcova Reservoir locality (Fig. 4C). This locality is closest to the geographic center of the Alcova Limestone occurrence (Fig. 1), where the limestone is the thickest (Fig. 2). This unit's stratigraphic assignment is ambiguous; this unit could be considered either the topmost unit of the Red Peak Formation, the lowest unit of the Alcova Limestone or a distinctive unnamed separate unit.

This alternating red bed and calcareous sandstone lithofacies are defined by alternating beds of light gray (2.5 Y 7/1) to tan (2.5Y 7/4) calcareous sandstone and red (2.5YR 5/6) sandy siltstone (Fig. 4. In outcrop, distinguishing the calcareous sandstone from limestone (Fig. 4D) is challenging due to similar color and vigorous $\mathrm{HCl}$ reaction. However, thin sections (Fig. 4E) show that the calcareous sandstone is composed of sand-sized quartz grains cemented with calcite. Red beds are characterized by fine silt or smaller grains with abundant peds (Fig. 4C). The bedding of the parent material, consisting of thick planar laminations and thin beds (up to $1.5 \mathrm{~cm}$ thick), can be distinguished, in places, through a pedogenic overprint. A gradient defines bedding in color from tan (2.5Y 7/4) to dark red (2.5YR 3/6), as well as subtle grain size differences, with some sand lenses in the silt and mud. An overprint of burrows, peds, and root casts partly obscures bedding. Burrows are present, defined by subtle color and grain size changes (Fig. 4C, point 1). Burrows are filled with slightly courser and lighter grains. The largest burrow runs parallel to the bedding plane surface for $10 \mathrm{~cm}$, with a $2 \mathrm{~cm}$ shaft and a $4 \mathrm{~cm}$ chamber at the end. Large cracks filled with coarser tan sediment are up to $2 \mathrm{~cm}$ in diameter at their origin and taper (Fig. 4C, point 2). Peds are weakly formed sub-angular blocky and oriented along with relic parallel bedding (Fig. 4C, point 3). The uppermost $1 \mathrm{~m}$ of the alternating lithofacies overlies a thin bed of the red siltstone, which here is only $0.5 \mathrm{~cm}$ to $2 \mathrm{~cm}$, appearing as little more than siltstone partings in a bedded sandstone (Fig. 4D). The contact between the red beds and the sandstone is undulatory and is marked by sand-filled burrows (Fig. 4C, point 1). 

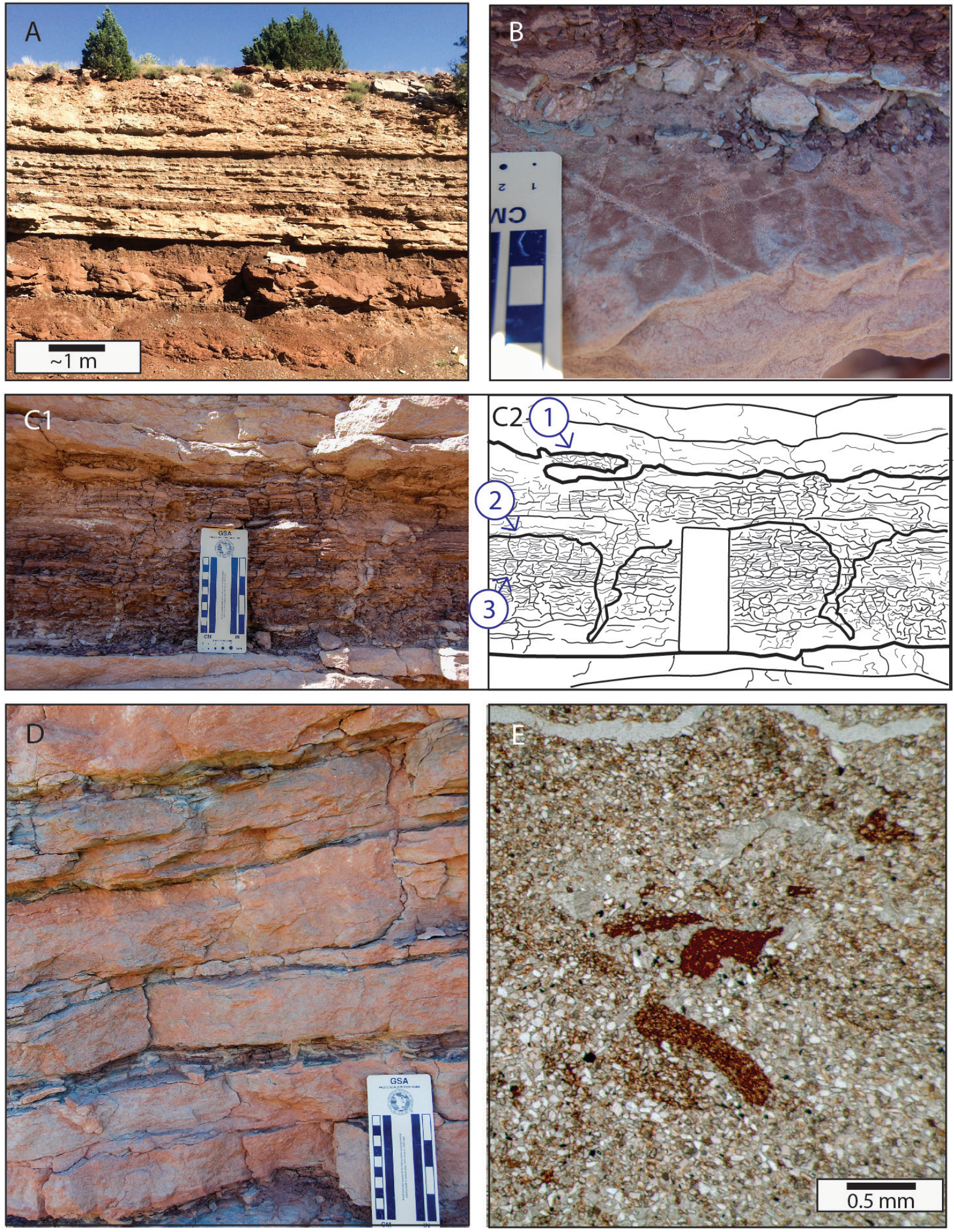
Fig. 5: The alternating red bed and calcareous sandstone lithofacies. A. shows the outcrop at the Alcova Reservoir location. B. Bedding plane exposures are marked by current ripple marks and polygonal cracks. C1/C2. Red beds include burrows (point 1 in C2), root casts (point 2), and weakly developed peds with traces of original planar bedding (point 3). D. Stratigraphically high red beds contain silt partings between parallel beds of calcareous sandstone. E. Thin section photomicrograph of calcareous sandstone with red mudstone rip-up clasts.

Sandstone strata within this lithofacies exist in bedded units between 3 and $55 \mathrm{~cm}$ thick, with an average thickness of approximately $8 \mathrm{~cm}$. The first sandstone unit is the thickest at $55 \mathrm{~cm}$, with subsequent units between 3 and $25 \mathrm{~cm}$ thick. Individual, 1-3 cm thick, thin beds are undulating and continuous. Bedding surfaces have polygonal cracks, current ripple marks, and reduction spots (Fig. 4B). Other sedimentary structures are rare, consisting mostly of current ripple cross-lamina and sub-horizontal cracks. Suspect leaf impressions are also present. The sandstone is comprised of bimodal medium sand and very fine sand (Fig. 4E). The medium sand is angular to sub-angular, highly spherical quartz grains without iron oxide coatings. Very fine upper to very fine lower sand is sub-angular to sub-rounded and comprised of quartz ( $\sim 90 \%)$, feldspar ( $\sim 10 \%)$, and minor amounts of mica and lithic fragments. The sand is cemented by calcite and minor amounts of iron oxide. A texture of interlocking crystal mosaic of calcite was observed in patchy areas of thin sections with cracks filled with fine calcite cement. Rip-up clasts composed of red mudstone were noted in very fine lower sandstone and siltstone in an iron oxide cement. Rip-up clasts are well rounded, between $0.5 \mathrm{~cm}$ and $1 \mathrm{~cm}$ long and 0.2 and $0.6 \mathrm{~cm}$ wide.

\section{Interpretations}

The alternating red beds and calcareous sandstone lithofacies underlies the central, thickest part of the Alcova Limestone. This lithofacies suggests deposition in an ephemeral lacustrine-mudflat system subject to flooding and desiccation. The red beds were deposited in mudflats or shallow water. Parallel laminations in red mud and silt associated with sand lenses, cracking, and current ripples are consistent with deposition in saline mudflats or ephemeral saline lakes (Hardie et al. 2009; Lowenstein and Hardie 1985). Siltstone and mudstone with sand lenses, bedding defined by red gradations, and hematite cement are consistent with modern deposition in arid saline mudflats (Benison et al. 2007). During drier periods, the mudflats were colonized by plants and animals and were subject to soil formation. Tan bedded calcareous sandstones were deposited during sheet floods. Sheets of sands, deposited by flooding or pulses of water, are common features of ephemeral lacustrine and playa systems, including systems forming red beds (Eugster and Hardie 1975; Hardie et al. 2009; Benison and Goldstein 2000). The alternating red beds and calcareous sandstone lithofacies likely represents the nascent Lake Alcova. 
This ephemeral lacustrine deposition's initiation represents the first actual deviation from the widespread and temporally long-lived environments of the pre-Alcova red beds. Thus, this unit of alternating red beds and calcareous sandstones is essential to understanding the onset of deposition environments recorded in the Alcova Limestone. This initial lacustrine landscape may have been relatively restricted in geography, only present in the outcrops surrounding the Alcova Reservoir. However, this deviation in the depositional environment is extraordinary in the context of the underlying Red Peak Formation, representing a fundamental change in the system's hydrology.

The alternating red beds and calcareous sandstone lithofacies represents a dramatic and significant climatic shift from the underlying Red Peak Formation. Icnofacies assemblages and morphologies are consistent with periodic colonization of a stable land surface with significant moisture during the dry periods (Hasiotis et al., 2007). Though classified as entisols (Retallack 1998), soil morphology indicates shorter duration soil development in wetter conditions. Sub-angular peds forming wedges indicate more shrink-swell action in wetter environments (Tabor et al., 2017). The alternating red beds represent more than just a lateral facies shit within the Red Peak Formation, but rather a fundamental climatic shift; the return of a dynamic hydrologic system and recolonization of the land surface by life could only occur through moderation of the climate.

\section{Basal Sandstone of the Alcova Limestone}

\section{Description}

The basal sandstone lithofacies (Bss on Fig. 3, Fig. 5), along with the alternating red bed and calcareous sandstone lithofacies, comprises either the lowermost unit of the Alcova Limestone or the uppermost unit of the Red Peak Formation. The unit is unambiguously clastic in origin but has higher calcite content than underlying beds. Herein, these lithofacies, like the alternating red beds and calcareous sandstone, has been grouped with the Alcova Limestone as a genetically related environmental perturbation from the surrounding red beds.

The basal sandstone lithofacies does not appear the same at all four outcrops examined. At the Scotts Plunge, Willow Hill, and Red Valley localities, the limestone units of the Alcova Limestone conformably overlie a clastic unit referred to here are the basal sandstone unit. It is distinct 

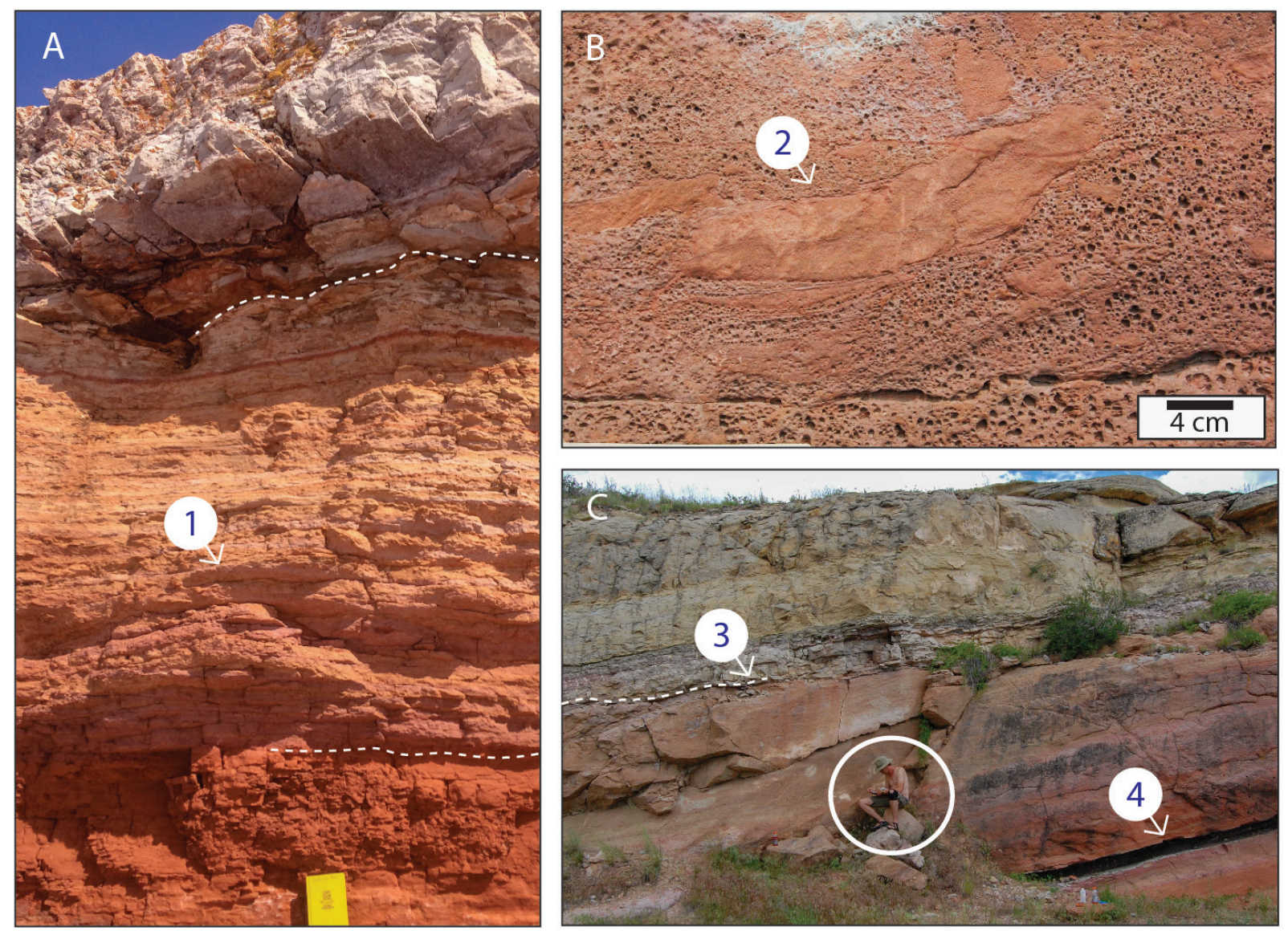

Fig. 6: The basal sandstone lithofacies (BSS). A. Exposure at Red River Valley, as seen along the valley A reactivation surface (Point 1) with onlapping beds. B. Large rip-up clasts up to $4 \mathrm{~cm}$ in diameter (Point 2) Scotch Plunge locality. C. The BSS at the Scotch Plunge locality, sitting person for scale, with an erosional contact with the overlying carbonate (Point 3) with nearly $1 \mathrm{~m}$ of topography. Units of the BSS are separated by a dark red siltstone unit (Point 4).

from both the underlying Red Peak Formation and the overlying limestone that comprises most of the Alcova Limestone. At the Alcova reservoir site, the Bss facies is not present. This unit is a lighter color and larger grain size at all localities present than the Red Peak Formation. It overlays and has conformable contacts with the units above and below.

At the Red Valley Locality near Lander (Fig. 5A), the basal sandstone is a fine to medium-grained, well-sorted variegated red (10R 4/8), tan (5Y 8/3), and light red (10R 7/6) sandstone. The contact between this sandstone and the massive limestone above comprises cm-scale alternating thin beds of sandstone and limestone mudstone. These couplets of sandstone and limestone are wavy and continuous over the entire outcrop. The variegated colors cross-cut 
bedding, just sub-parallel to bedding in the direction of dip. Bedding in the sandstone is $3-5 \mathrm{~cm}$ thick and continuous at the site of the measured section at Red Valley. The outcrop can be walked at the surface for $4.6 \mathrm{~km}$ along the Red Valley with the basal sandstone well exposed (Fig. 6A). The most notable sedimentary structure is large-scale trough cross-bedding (Fig. 6A, point 1). Trough cross-bedding foresets are concave-up, up to $90 \mathrm{~cm}$ in height, and over up to $1.5 \mathrm{~m}$ in length are found at all sites. Other sedimentary structures are ambiguous, such as weakly defined laminations, rare impressions that may be leaf fossils, and cracks associated with later tectonics.

At the Willow Hill locality, the basal sandstone is a fine to medium red (10R 6/6), fissil, rippled sandstone. The sandstone has some weakly defined trough cross-bedding in some locations. This trough bedding has a maximum height of $10 \mathrm{~cm}$ with concave-up foresets up to $50 \mathrm{~cm}$ long. Ripples are asymmetric (current) ripples in bedding plane and climbing ripples in cross-section. Rare, weekly defined sub-vertical burrows disrupt ripple lamina with maximum dimensions of 1 $\mathrm{cm}$ wide and $3 \mathrm{~cm}$ long. Rip-up conglomerate beds are up to $15 \mathrm{~cm}$ thick with imbricated rip-ups up to $6 \mathrm{~cm} \times 4 \mathrm{~cm}$.

At the Scotch Plunge locality, the basal sandstone of the Alcova Limestone lithofacies is a red (10R 6/6) to pink (2.5R 8/4) medium sandstone with large rip-up clasts comprised of siltstone (Fig. 6B). The contact with the overlying massive limestone lithofacies has approximately 0.5 $\mathrm{m}$ of topography (Fig. 6C, point 3). The unit is divided into two 4 to $4.5 \mathrm{~m}$ thick sandstone units separated by a recessive dark red (10R 3/4) fine siltstone (Fig. 6C, point 4). The sandstone beds have a pock-marked erosional pattern and large (up to $10 \mathrm{~cm}$ ) angular intraclasts, root casts, and trough cross-bedding. Some rip-ups are extremely large, imbricated, up to $60 \mathrm{~cm}$ in length with a maximum cross-section of $4 \mathrm{~cm}$ (Fig. 6B, point 2). The pock-marked bed has poorly-defined trough cross-bedding present with homogeneous and heterogeneous foresets onlapping onto irregular surfaces.

\section{Interpretation}

The basal sandstone units represent a dramatic shift in facies from the low-energy sheet flood deposits and soils towards a high-energy environment. It is commonly accepted that trough cross-bedding originates from the migration of 3D dunes in environments as varied as fluvial systems to prograding shorelines (Harms et al. 1975; Miall 1988). Trough crossbedding alone is insufficient to assign an environment of deposition. Current ripples, climbing ripple cross-lamina, 
and imbricated rip-up clasts indicate formation in unidirectional flow. The rip-up conglomerate with unusually large clasts indicates extreme flooding events where a strong overland water flow disrupts the previously dry land surface. The parting red shale between rip-up clast conglomerate beds (Fig. 6, Point 4) could represent shallow lakes and mudflats that form between events, a period of soil formation, or both.

The basial sandstone represents a fundamental alteration in the hydrologic regime, marking periodic catastrophic flooding, wind reactivation, or combining the two. Sediment accumulating as alluvium in a closed basin can be reactivated and accumulate with a drop in the water table, forming similar cross-bedding in the formation of dunes. A similar reactivation process is attributed to the formation of Great Sand Dunes in Colorado (Madole et al. 2008; Marzolf 1988), where large periodic fluxes of overland flow and changing water table both contribute sand-sized sediment to the system. The large rip-ups are indicative of at least periodic steady unconfined water flow. However, the reworking of this by a robust wind regime is also possible.

\section{Massive Carbonate Mudstone-Wackstone Lithofacies of the Alcova Limestone}

\section{Description}

The massive carbonate mudstone-wackestone lithofacies (Am on Fig. 2) is the lowermost limestone lithofacies of the Alcova Limestone (Fig. 3, 7). It is a pale green-grey (GLEY 7/10Y) to grey (GLEY 5/N) or pink-grey (5YR 7/2) (Fig. 7A, B) cohesive single bed up to $60 \mathrm{~cm}$ thick and is present at all localities as either a carbonate mudstone or a mudstone-wackestone where some shells are present. The XRD results show the unit is approximately $91 \%$ calcite and $9 \%$ quartz. The massive carbonate mudstone-wackestone lithofacies overlays either the basial sandstone lithofacies of the alternating red beds and calcareous sandstone lithofacies with an undulatory conformable contact showing no evidence of erosion. The massive carbonate mudstone-wackestone lithofacies alternates with the basal sandstone lithofacies for three cm-thick couplets at the Red Valley locality near Lander (Fig. 7C).

The massive carbonate mudstone-wackestone lithofacies has a sugary crystalline texture and abundant vugs (Fig. 7B). Wavy pink bedding and lamina are areas with more iron oxide coated grains (Fig. 7D) and iron oxide cement (Fig. 7E, Point 3). Evidence for diagenesis includes recrystallized areas with an interlocking crystal mosaic disrupting the original texture (Fig. 7E, 

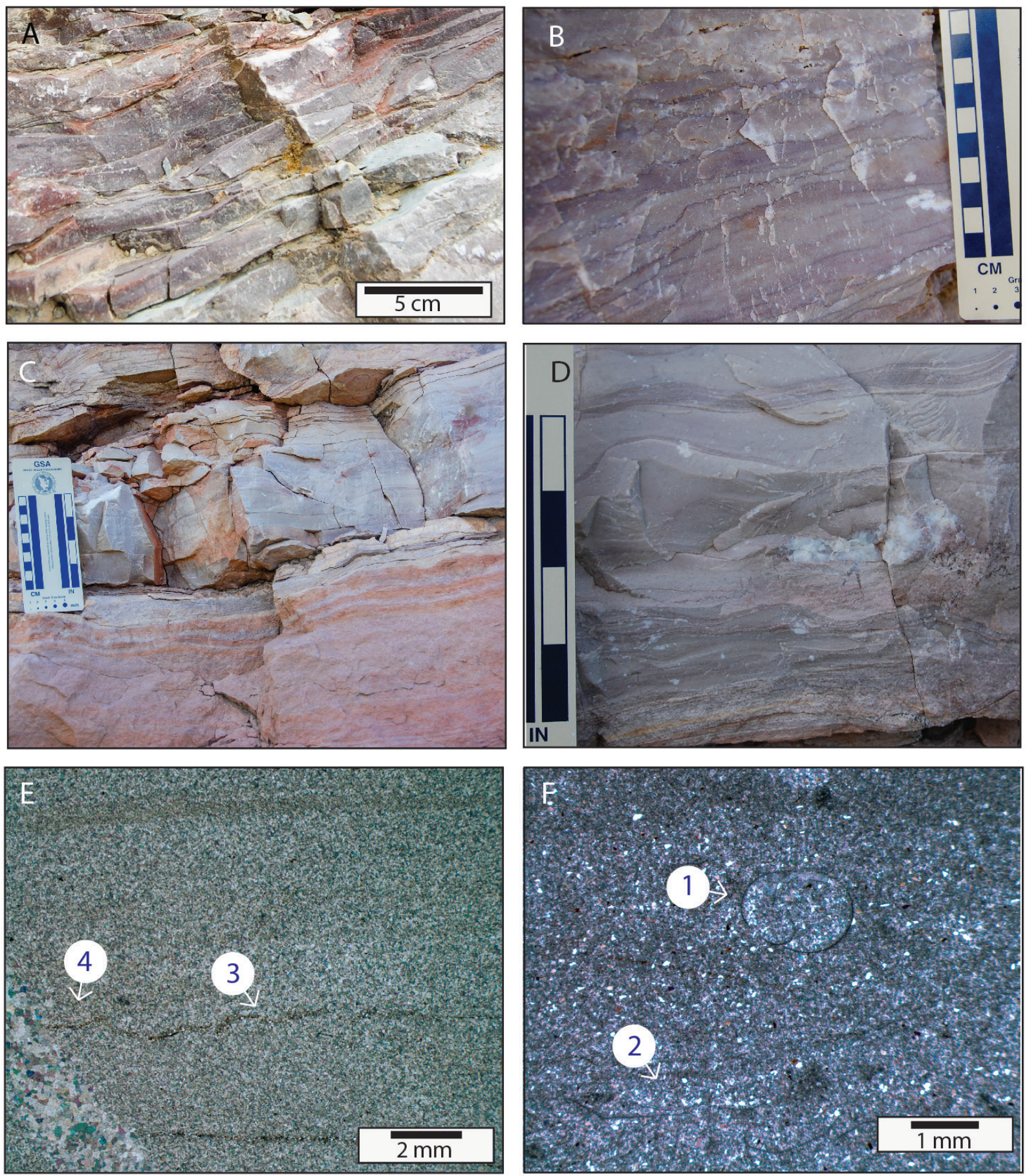

Fig. 7: The massive mudstone lithofacies. A. Red layered carbonate at Scotts Plunge locality could be terra rosa. B. Pink-red wavy lamination with vugs at the Willow Hill locality. C. At the Red Valley locality, the lithofacies' upper surface has been eroded and filled with a tan sandstone while the lower contact alternates between carbonate and sandstone. D. Wispy pink laminations. E. Photomicrograph of iron oxide cement (Point 3) and large recrystallized area (Point 4). F. Evidence of invertebrate life with a likely gastropod (Point 1) with courser crystalline carbonate and articulated bivalve shells (Point 2) in a photomicrograph from the Alcova Reservoir locality. Invertebrates are too poorly preserved not diagnostic of any environment of deposition. 
point 4), and large vugs are filled with a blocky calcite cement (Fig. 7D). However, some suspect gastropods and shell fragments were observed (Fig. 7E).

Elemental maps of the massive carbonate mudstone-wackestone do not show any additional bedding that can be clearly defined by an increase in $\mathrm{Si}$, Ti, and Al. However, an increased Si and $\mathrm{Mg}$ area, likely enhanced through diagenesis, is present in the lower right part of the thin section. Disrupted bedding is defined by both silicon and magnesium (Fig. 8). Sulfur is present in concentrations as high as $1.2 \%$, well above the normal background of sulfur in marine systems. Ths sulfur is concentrated in linear trances sub-vertical and sub-horizontal to bedding surfaces. The elemental maps also show iron, titanium, and aluminum increasing from bottom to top of the sample. $\mathrm{Fe}$ and $\mathrm{Ti}+\mathrm{Al}$ are relatively consistent throughout the sample.

No vertebrate fossils were found. Poorly preserved shells, often coarsely recrystallized through diagenesis, are rarely observed in outcrop. In thin section, gastropods (Fig. 7F, point 1) and bivalves (Fig. 7F, point 2) can be identified that were not seen in hand sample. Shells are in a carbonate mud matrix with abundant angular well-rounded fine sand and silt. No fossil or trace fossil was well preserved enough for further identification.

The contact between the massive carbonate mudstone-wackestone lithofacies and overlying lithofacies is defined by evidence of a sharp boundary. A well-developed terra rosa is formed at the boundary at the Alcova Reservoir locality (Fig. 7A). This weak red (10R 4/3) to dark red (10R 3/6) layer is approximately $4 \mathrm{~cm}$ thick and developed along a surface with evidence of erosion and dissolution. Small pockets of red silt are also found along with this layer. At the Red Valley locality, the massive carbonate mudstone-wackestone lithofacies has been incised by a channel filled with thin beds ( $3-5 \mathrm{~cm}$ thick) of $\tan (5 \mathrm{Y} \mathrm{8/3)}$ medium sand that onlaps the sides of the channel (Fig. 5A2, Point 1).

\section{Interpretation}

The massive carbonate mudstone-wackestone lithofacies were deposited in a short-lived, perennial low-energy lacustrine environment. The couplets of limestone and sandstone (Fig. 7E) represent the transition from the basal sandstone lithofacies to the massive carbonate mudstone-wackestone lithofacies as the paleo-water table gradually rose. Wispy pinkish bedding 

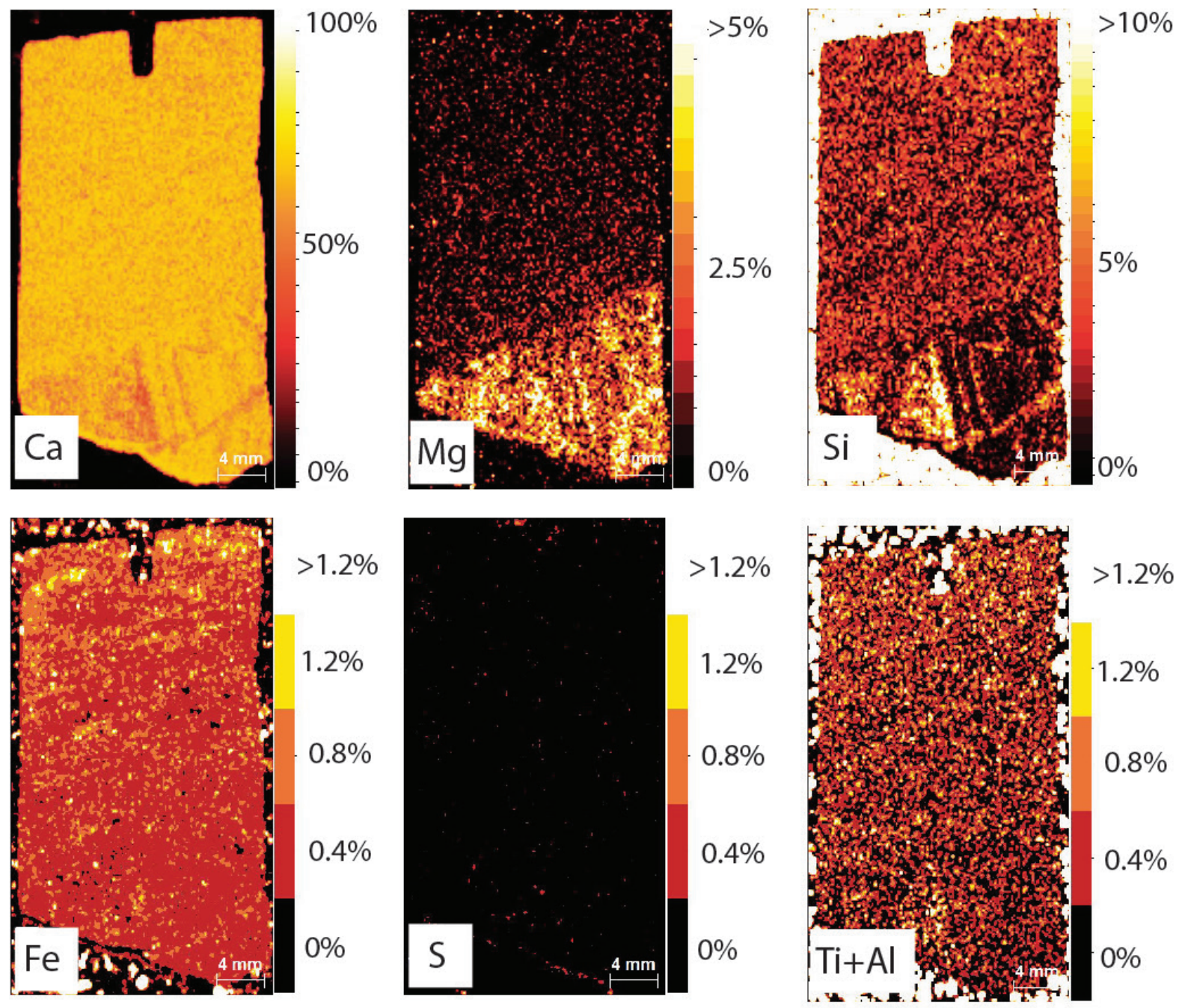

Fig. 8: Elemental concentration maps of a thin section of the massive mudstone lithofacies from the Willow Hill locality. Elevated silica levels define an area that could be disturbed bedding but do not correspond to elevated titanium and aluminum or variations in iron that has previously corresponded to bedding. Elevated magnesium in the same region is possible evidence of dolomitization. Areas of elevated sulfur form blobby lineations. This elemental distribution could be the result of extensive alteration through diagenesis. 
associated with abundant angular silicate grains and iron oxide cement is consistent with regular eolian dust or sand inputs. Recrystallized areas, some greater than $2 \mathrm{~mm}$ in diameter, have shapes suggestive of burrows where slightly more porosity of burrow fill may have facilitated recrystallization. This thin basal unit was subaerially exposed, as evidenced by exposure surfaces where terra rosa developed (Fig. 7F) and erosion by fluvial systems (Fig. 4A, 7E) with clastic lateral accretion.

The fossils of the massive carbonate mudstone-wackestone lithofacies are not diagnostic of any specific environment, although the bivalve shells suggest a subaqueous setting of brackish or less salinity. However, they do indicate an environment where life was at least extant, if not thriving. All shells are articulated, indicating a low energy environment. The presence of bivalves and gastropods suggests the environment was not hypersaline but could be fresh, brackish, or saline. The pink wavy lamina or beds were deposited by differential inputs of siliciclastic silt and sand, likely seasonal variations in the wind. Although this study found no Corosaurus reptile fossils, documentation of this fossil in the Alcova Limestone has been used to indicate a marine environment of deposition (Rieppel 1998; Storrs 1991) due to the presence of salt pits on the skull. Setting aside that the precise sedimentological relationships of the Corosaurus remain unreported, the anatomy of the reptile indicated only that it lived in brackish to saline environments, so possible lacustrine deposition should not be overlooked. No other Corosaurus has been reported from North America, further limiting its paleoenvironment usefulness.

It is possible that many smaller co-existing lakes covered this region. This first carbonate lacustrine system was relatively short-lived, depositing only a single bed, though of sufficient thickness to be perennial. At Red Valley, the massive carbonate mudstone-wackestone was incised by a channel that deposited laterally accreting beds as a fluvial system migrated over the exposed area. Exposure surfaces in all localities between the massive carbonate mudstone-wackestone lithofacies and overlying lithofacies indicate that this exposure was after deposition of the perennial lake.

A sugary texture, vugs, calcite cement, and interlocking crystal mosaic indicate that the massive carbonate mudstone-wackstone unit's diagenetic alteration occurred. The interlocking crystal mosaic is a neomorphic fabric, indicating either recrystallization or replacement altered the original material. This neomorphism has obscured the original textures. 
The elemental magnesium and silicon maps could have ghosts of distorted bedding, though faint and indistinct. However, the increase in $\mathrm{Si}$ is not accompanied by an increase in $\mathrm{Ti}+\mathrm{Al}$ as it is in other places. These ghost beds defined by elemental distributions could be traces of original chemical composition that may have been lost during recrystallization. The increase in $\mathrm{Mg}$, likely as part of an incomplete dolomitization process, is restricted to this area of high silica. The altered area is sub-parrel to bedding and could not be seen in either a hand sample or a light microscope. A pattern of sulfur in a linear series of blobs is present in the sample. This sulfur is in concentrations in excess of $4000 \mathrm{ppm}$, suggesting a source for the sulfur that is no longer extant in the sample. The most logical source would be gypsum-This "ghost" gypsum, with the interlocking crystal mosaic texture and the high $\mathrm{Mg}$ content, may be evidence that original beds of gypsum were replaced by the calcite dominant in the Alcova Limestone today.

\section{Wavy Laminated Carbonate Lithofacies of the Alcova Limestone}

\section{Description}

The wavy laminated carbonate lithofacies (Aw in Fig. 2, Fig. 9) is a carbonate unit of the Alcova Limestone characterized by mm-scale alternating dark and light lamina up to $3 \mathrm{~mm}$ thick that pinch and swell in beds between 10 and $45 \mathrm{~cm}$ thick. No grains are visible in the outcrop, with the surface having a surgery texture where fresh. The lamina may be disrupted towards the top of the bed (Fig. 9A), where thin darker lamina outline angular or blade-like areas. Lamina form upward dooming structures where lamina can be traced through the structure and rarely onlap onto massive mudstone mounds. The lamina is either nearly wholly convoluted or has climbing ripple cross-lamination.

The lamina is light and dark. The lighter lamina is comprised of higher abundances of angular fine sand and silt (Fig. 10). XRD identified calcite and dolomite as major constituents and quartz as minor constituents. The micro-XRF concentration maps (Fig. 10) further elucidate the light wavy lamina's composition as those with higher concentrations of silicon, iron, aluminum, and titanium. Light laminations have $1.12-1.24 \% \mathrm{Si}, 0.22-0.35 \% \mathrm{Fe}$, and $0.22-0.35 \%$ each Al, $\mathrm{Ti}$, and K. In contrast, dark laminations contain higher trace element concentrations, with 3.60 $10.50 \% \mathrm{Si}, 0.35-1.00 \% \mathrm{Fe}, 0.37-0.85 \%$ each $\mathrm{Al}$, Ti, and $\mathrm{K}$. The ratio of aluminum to silicon in light laminations average 0.19 and, in dark laminations average 0.08 . Beds have an erosional base with lamina filling topography and onlapping onto the lower bed (Fig. 9). Thick and uneven cracks form triple junctions on bedding surfaces. This cracking pattern (Fig. 9G) is crosscut by thick triangular cracks radiating from a central circular future. 

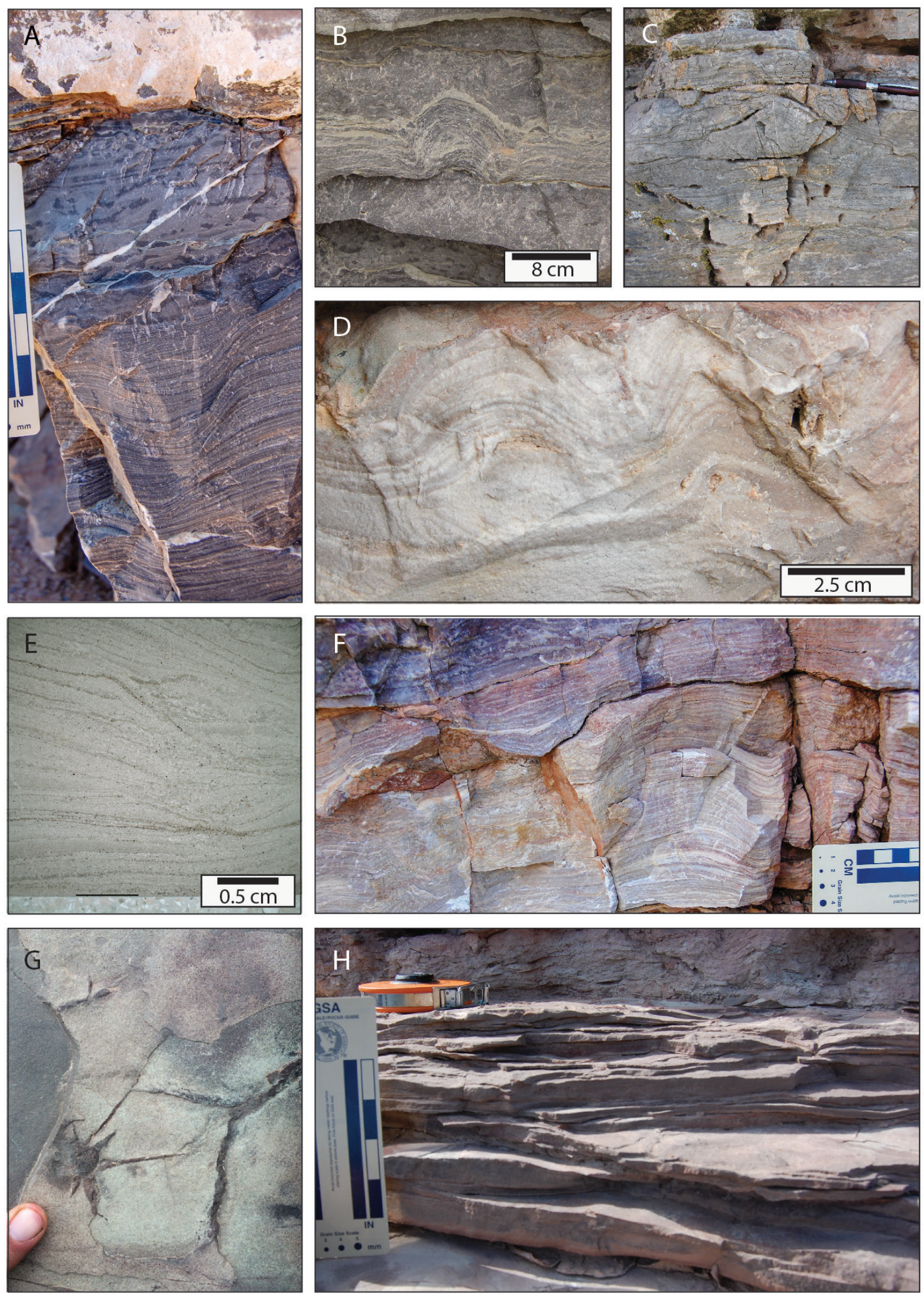
Fig. 9: The wavy laminated lithofacies in outcrop at the Will Hill locality (A to C), the Red Valley locality ( $D$ and $E)$, and Alcova Reservoir locality $(F$ to $H)$. A. Wavy pinch-and-swell lamina grade into disrupted bedding. B. Small upward-dome lamina continuous with the adjacent horizontal parallel lamina. C. Lamina onlaps massive mounds. D. Convolute bedding. E. Climbing ripple lamina. F. Beds with erosive tops. F. Lamina onlapping the lower surface. G. Bedding plane exposures with ripple marks, fluid escape features, and mud cracks. H. Tangential view of bedding plane exposure in $G$ showing ripple lammana forming wavy bedding in cross-section.

\section{Interpretation}

The wavy laminated carbonate mudstone lithofacies (Aw in Fig. 2) was deposited in a hypersaline lacustrine system. The laminations maintain their thickness through many of the "hills and valleys" of the wavy bedding. The laminated domes lack upward-mounded trends, as many of the "domes" appear to dip downward as well as upward. The silica that defines the lamina is angular silt-sized grains. True stromatolites tend to be thickest at the top and pinch between heads. The sediment that defines laminations in stromatolites formed in marine environments is more rounded and often entrapped with other grains such as shell fragments and thin dark grains with thicker light-colored layers. Both patterns are absent in these lithofacies.

The wavy laminations are similar to lamina in other thin carbonate beds, such as the Codocedo Limestone (Bell 1989). Pinch and swell lamana are common in an environment where pelagic sediment settles out of the water column. Alternatively, similar pinch and swell laminations are common in environments with alternating carbonate and gypsum production, like the Castille Formation of Texas (Anderson et al. 1972). Laminations may be preserved in either deepwater environments or hypersaline environments without benthic life. Mudcracks and angular cracks are consistent with a hypersaline environment where changing water levels frequently causes subaerial exposure. The paucity of fossils also supports a hypersaline environment of deposition.

The smaller upward-oriented laminated domes in these lithofacies (Fig. 9B, D, F) could be one of four features: (1) teepee structures, (2) soft-sediment deformation, (3) bottom-growth gypsum splays, or (4) microbial mounds. Insufficient evidence exists to identify the specific origin. However, all four are consistent with deposition in a shallow saline system (perhaps hypersaline) with periodic exposure. Disrupted bedding (Fig. 9A) is consistent with haloturbation. The evaporites' growth below the sediment surface disrupts bedding and laminations, particularly with shallow water and evapoconcentration. Alternatively, bottom-growth gypsum crystals draped in iron oxide-rich mud may be replaced by carbonate. 

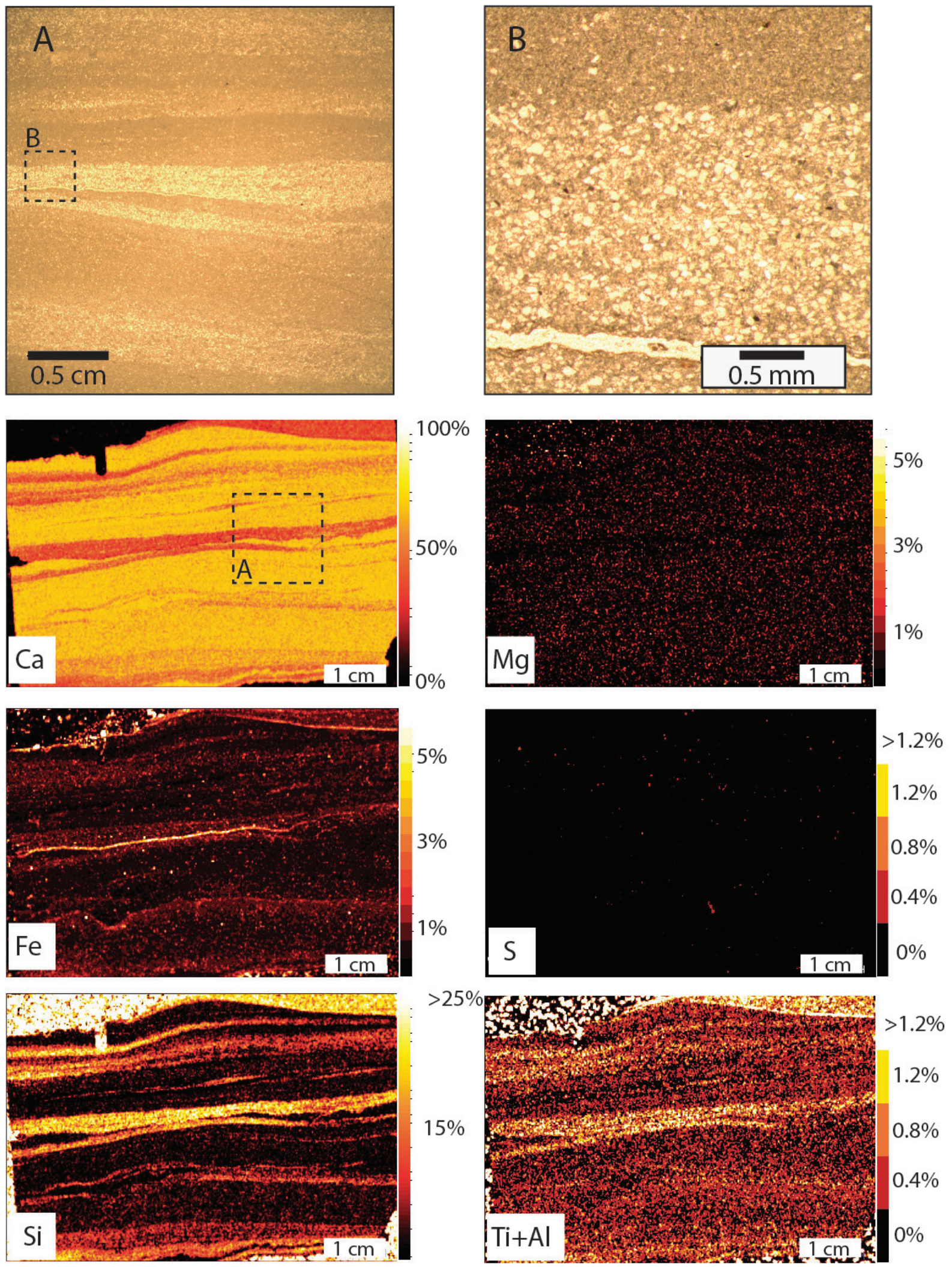
Fig. 10: Photomicrographs of the wavy laminated lithofacies (A, B) and elemental concentration maps of Calcium (Ca), Magnesium (Mg), Iron (Fe), Sulfur (S), Silicon (Si), and the addition of Titanium and Aluminum (Ti+Al), a proxy for clays. Dashed boxes indicate the approximate location of photomicrographs. Higher concentrations of silica and clays define wavy pinch and swell lamina. Iron concentrations are highest in crack filling cement.

\section{Crinkle Bedded Limestone Lithofacies of the Alcova Limestone}

\section{Description}

The crinkle bedded limestone lithofacies (Ab in Fig. 2) is the Alcova Limestone's uppermost unit at all three locations. Small upward oriented domes in bedding plans (Fig. 11A) for distinctive crinkly laminations grouped into bedsets (Fig. 11B). Mm-scale continuous parallel lamina form bedsets up to $75 \mathrm{~cm}$ thick, forming larger upward oriented domes (Fig. 11C, D). Lamina is often disrupted by small v-shaped mud cracks (Fig. 12), internal scour surfaces, and small-scale disrupted bedding that is likely fluid escape features. The "crinkle" appearance is due to angular wedge-shaped "kinks" in thin dark lamina separating thicker, lighter lamina.

Bounding surfaces on beds are undulatory, with centimeters of erosional relief. Bedding surfaces have transverse and slightly asymmetrical, climbing ripples, cracking, reduction spots, polygonal cracks, and suspect vertebrate footprints. A single set of suspect footprints forming an ambiguous trackway was observed in the large bedding plane exposure surface at the Willow Hill site (Fig. $10 \mathrm{E})$.

The crinkle bedded limestone lithofacies is dominated by an interlocking crystal mosaic when viewed in thin section (Fig. 12A, 11D). The laminations are defined by silt to very fine sand quartz grains (Fig. 12B, 12C). Some grains are coated with iron oxides (Fig. 12D, 112E), particularly towards beds' tops. Lamina is nearly always parallel and continuous (Fig. 112E), though some bedding is disturbed (Fig. 11B). Ambiguous calcite-filled irregular vertical shafts (Fig. $12 \mathrm{~F}$ ) are likely deformed mud cracks into a weathered surface. The irregular surface causes the "crinkle" in the crinkle lamina in the thinner, darker lamina (Fig. 12E) that are also characterized by higher Fe, Si, and Ti and Al content (Fig. 13). XRF identified calcite and dolomite as major constituents and quartz as a minor constituent. A fourth phase could be gypsum, but could not be differentiated well. The XRF elemental maps demonstrate areas with higher sulfur content. 

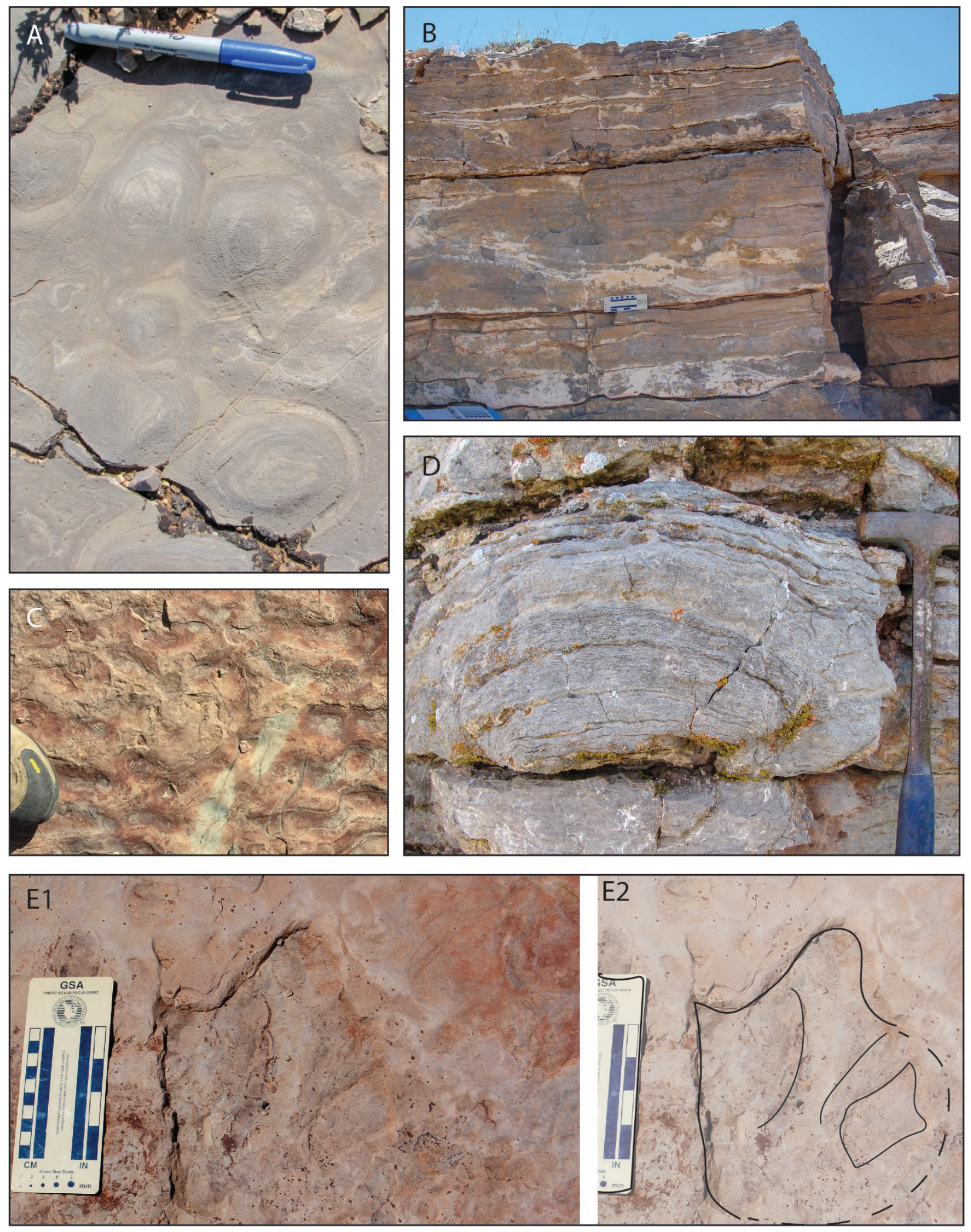
Fig. 11: The bedded carbonate lithofacies in the outcrop at the Willow Hill locality are extensively exposed and quarried. A. Small upward dome lamina. B. The distinctive crinkle lamination pattern in the outcrop is associated with the small upward dome lamina. $C$. The tops of beds are defined by ripple marks and cracking. D. Some broad upward dome lamina are draped by overlying beds. E. A single track of suspect footprints is visible in the large exposed bedding surface cleared for a quarry.

\section{Interpretation}

The bedded carbonate lithofacies (Ab in Fig. 2) was deposited in shallow ephemeral saline to the hypersaline lacustrine system. Current ripples, wave ripples, cracks, polygonal cracks, and trackways on the bedding planes are indicative of shallow-water deposition and occasional subaerial exposure. The bedding itself is likely a result of this exposure, while the lamina results from periodic inputs of aeolian dust or periodic chemistry changes in saline or hypersaline system resulting in precipitation, perhaps onto bottom growth gypsum. The lamina is defined by very high $(>1 \%)$ concentrations of $\mathrm{Fe}$, and up to $5 \% \mathrm{Ti}+\mathrm{Al}$, consistent with hematite and other clays that are known to form in modern hypersaline lacustrine systems (Benison et al. 2007; Calvo et al. 2009).

In the bedded carbonate lithofacies, evidence for life includes articulated bivalve fossils, burrows, disrupted bedding, and microbial features. Upward doming lamina is convincingly stromatolites. The "crinkle" surface, termination of lamina at the dome edges, and more regular lamina all support a benthic microbial binding of sediment. Stromatolites suggest depositional conditions extreme enough in temperature, salinity, or chemical composition to preclude browsers. Stromatolites have been described in restricted marine, intertidal, lacustrine, springs, and cave deposits (Riding, 2000). Like those in the massive carbonate mudstone lithofacies, Burrows are implied by areas with coarser crystals than in surrounding rock (due to either recrystallization or replacement) that outlines the shape expected from a burrow (Fig. 12A). Disrupted bedding is accompanied by a sulfur anomaly (Fig. 13) that could indicate relic organic matter.

\section{Post-Alcova Red Beds of the Crow Mountain Formation}

\section{Description}

The Alcova Limestone is conformably overlain by the red beds of the poorly exposed Crow Mountain Formation of the Chugwater Group (High et al. 1969). At most outcrops of the Alcova Limestone, the Crow Mountain Formation is a poorly exposed slope former. At no location is any erosion or truncation of the Alcova evident. 
At the Red Valley road cut in Lander WY, the Alcova Limestone is overlain by a succession of red siltstones and sandstones (10 YR 4/4 to 4/8; 2.5 YR 3/3 to 3/6). Just above the Alcova Limestone, bedding is remarkably similar to the pre-Alcova Red Peak Formation, with alternating recessive and resistant beds. The recessive beds are darker siltstone with abundant peds, cracks, and reduction features. Resistant beds have cracking, climbing current ripples, and internal scour surfaces. The recessive beds become thicker up-section throughout the approximately $100 \mathrm{~m}$ of the outcrop, cumulating in a nearly $15 \mathrm{~m}$ thick single bed with root traces, cracks with slickens, large blocky peds, and clay cutans.

At the Willow Hill locality, the Alcova Limestone is overlain by a conglomerate with imbricated limestone and sandstone gravel. A bedded conglomerates with imbricated limestone, sandstone, and mudstone in a red matrix is present in the poorly exposed outcrop. Beds are up to $50 \mathrm{~cm}$ thick and onlap into an eroded channel surface in fine siltstone.
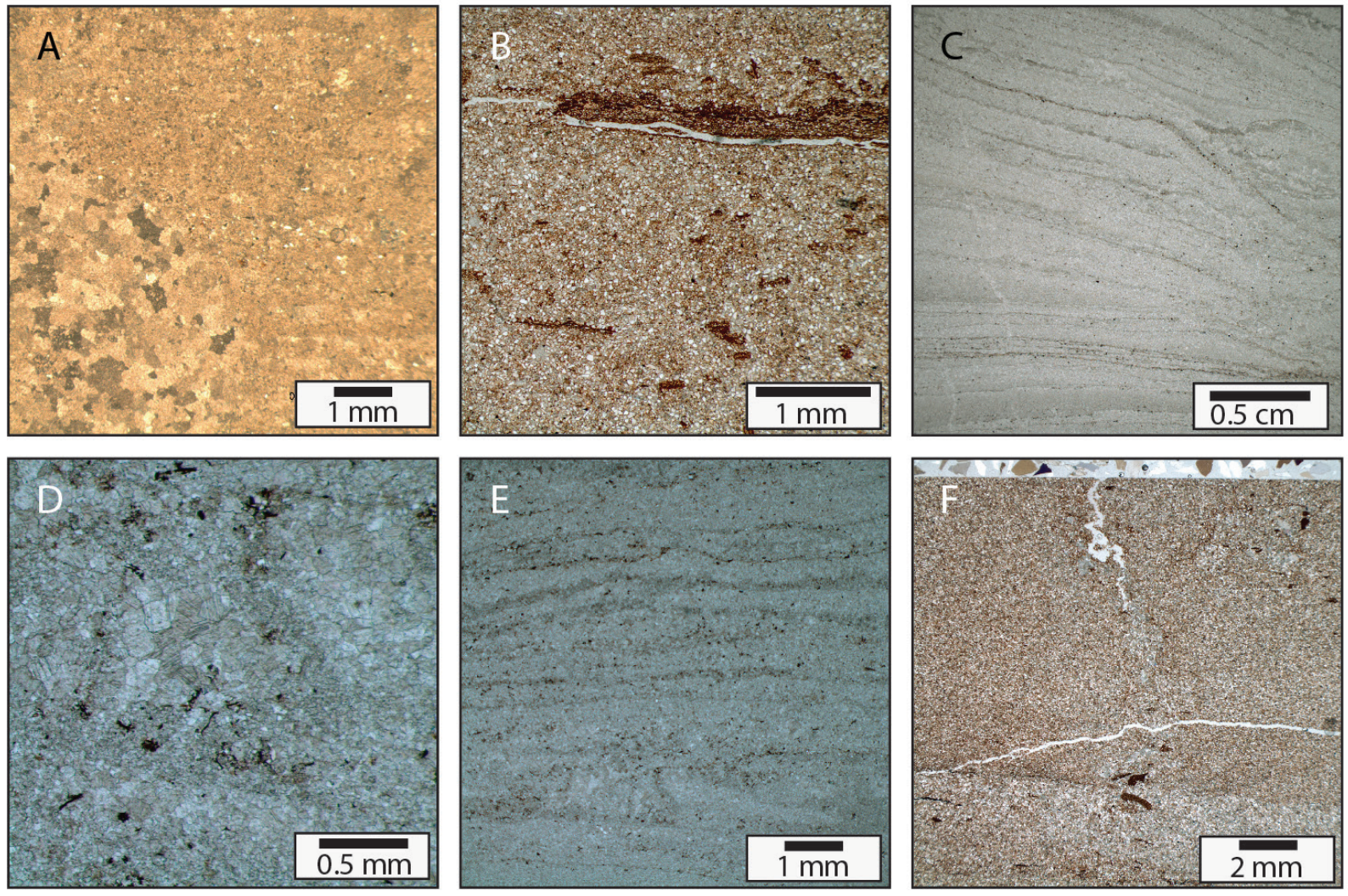

Fig. 12: Photomicrographs of the bedded carbonate lithofacies. A. Much of the lithofacies are recrystallized with interlocking crystal mosaic, possible in burrows. B. Rip-up clasts in a carbonate matrix. $C$. Slightly distorted laminations could be climbing ripples. D. Interlocking crystal mosaics with iron oxide cement. E. The crinkle lamina has angular kinks that may be draped onto bedding gypsum that has been replaced by carbonate. F. Rip-up clasts and compressed mud cracks near the bedding surfaces. 


\section{Interpretation}

A detailed interpretation of the Crow Mountain Formation is beyond this investigation's scope, but a general description is given to place the underlying Alcova Limestone in a stratigraphic context. Crow Mountain Formation is interpreted to be a continental red bed dominated by soils and rivers. The Crow Mountain Formation punctuates the Alcova Limestone deposition by a return to subaerial exposure. The well-exposed road cut through the Crow Mountain at Red Valley is a succession of paleosols. Near the Alcova Limestone, the paleosols are thin (less than $1 \mathrm{~m}$ ) and poorly developed. Up-section, the paleosols have the characteristics of a well-developed soil profile, including evidence of extensive roots. At the Willow Hill locality, the Crow Mountain's imbricated conglomerate with trough cross-bedding is fluvial in origin. In other locations, the Crow Mountain is not well enough exposed to provide an insight other than "red bed."
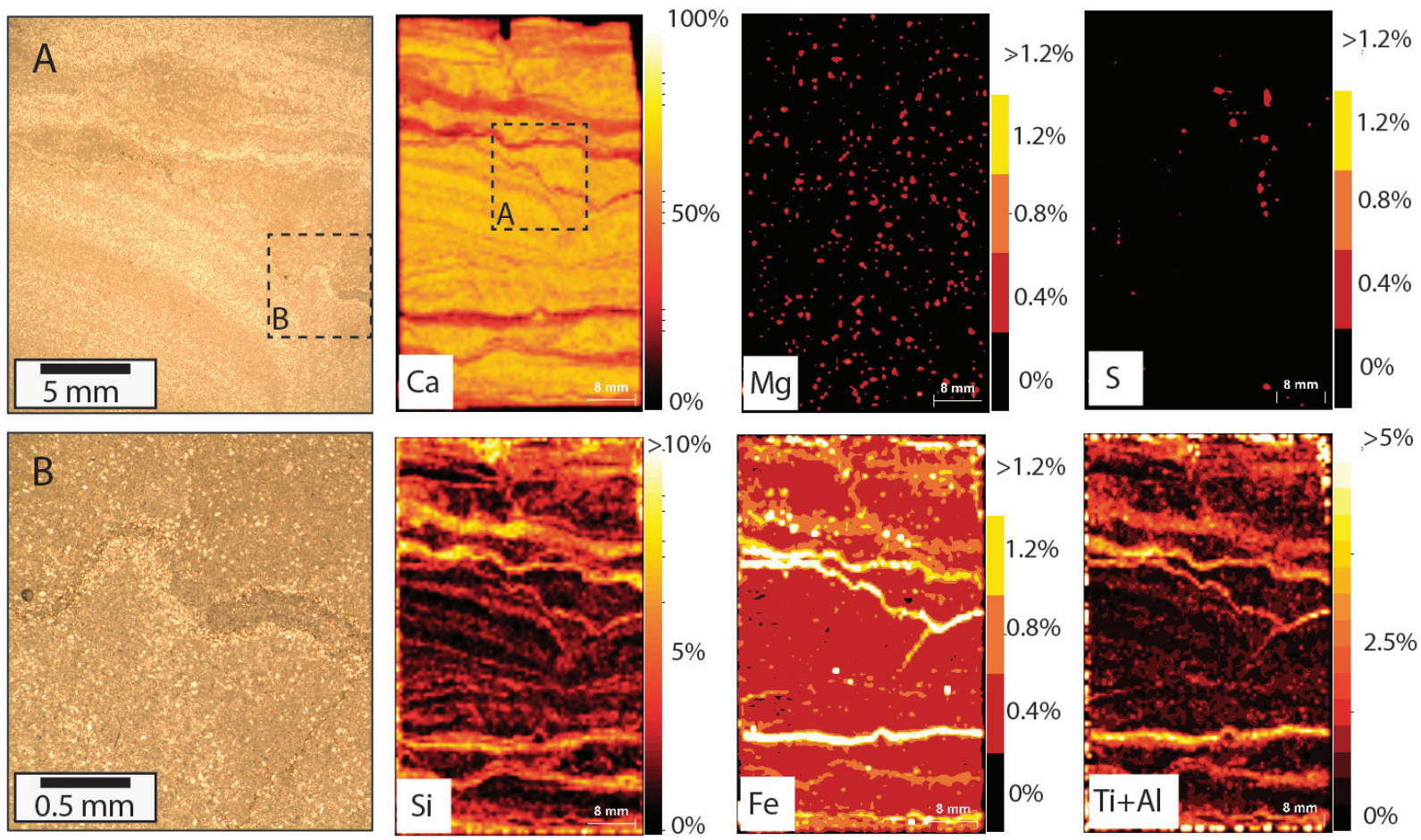

Fig. 13: The bedded carbonate lithofacies from the Willow Hill locality in photomicrograph (A, $B)$ and elemental concentration maps with dashed boxes to indicate photomicrographs' location. Lamina is defined by high concentrations of clays, iron oxides, and silica. The presence of Sulfur is associated with disrupted bedding. Magansusum is present but dispersed. 


\section{DISCUSSION}

\section{A Lacustrine Environment of Deposition for the Alcova Limestone}

The Alcova Limestone is notable for an abrupt transition from red beds to carbonate. The carbonate of the Alcova Limestone shows evidence for deposition in an ephemeral lacustrine environment as authigenic precipitation from the evapoconcentration of parent water or biogenic mediation and the replacement of gypsum by carbonate. The physical sedimentary structures in the Alcova Limestone are consistent with deposition in a lacustrine environment.

An extensive set of structures and features, such as cracking, terra rosa development, and erosion, are evidence for subaerial exposure. For example, at the Red Valley site near Lander, an erosional bounding surface is onlapped by laterally accreting sand, most likely deposited as a meandering channel across a desiccated lake bottom. Taken together, the assemblage of sedimentary structures, fossils, and trace fossils indicate deposition in shallow, regularly desiccated, saline to hypersaline environments.

Carbonate minerals are common in lacustrine environments, particularly in many saline lakes (Carroll and Bohacs 1999; Kelts and Talbot 1990; Platt 1989). Carbonates form in saline lake environments from one of four processes (Decima et al. 1988; Hardie et al. 2009): (1) precipitation resulting from evapoconcentration of parent waters, (2) biologically mediated precipitation, (3) diagenetic alteration of calcium sulfate minerals to calcium carbonate minerals, and (4) detrital transportation of carbonate rock clasts that have eroded from outcrops in the region and are deposited in lakes as clastic sediments. The evapoconcentration of seawater or brines with parent water enriched in bicarbonate results in calcium carbonate's direct precipitation. Biogeochemical precipitation of carbonates, particularly from the action of bacteria, results in distinctive sedimentological features such as isolated domes with lamina. Diagenetic alteration of calcium sulfate minerals to calcium carbonate minerals can occur through the action of sulfate-reducing bacteria or by interaction with $\mathrm{Na}-\mathrm{CO}_{3}$-rich fluids (e.g., Fernández-Díaz et al. 2009; Ulmer et al., 1992).

The exposure surfaces, erosion, and cracking in the Alcova demonstrate a lacustrine system the was not temporally persistent. However, it is unclear if the paleo "Lake Alcova" was ever a single unified body of water. The exact extent of any body of water within the Alcova system cannot 
be determined. It is impossible to tell if any bed set at one locality can be attributed to the same water body responsible for the deposition of a similar bed set at another locality. The area covered by the Alcova Limestone and associated units is significant, as much as $375 \mathrm{~km}$ from east to west. Judging by modern standards, this seems like a large area, but not unrealistically large for a system of evaporative lakes. The Bonneville Salt Flats is $187 \mathrm{~km}$ north to south. In Western Australia, a series of ephemeral saline lakes, many of them highly acidic

( Benison et al., 2007), fill paleo river channels in an area covering over 500,000 $\mathrm{km}^{2}$ and over $700 \mathrm{~km}$ from east to west. Climatic extremes in the late Permian and Early Triassic (Retallack 1999; Tabor 2013; Zambito and Benison 2013) could have transformed large low-relief closed and underfilled basin landscapes into evaporative landscapes more extreme than the lake systems of western Australia (Fig. 14).

\section{The Case Against a Marine Environment of Deposition for the Alcova}

gThe Alcova Limestone has been described as a marine limestone. The presence of limestone, fossil shells, and microbial structures have been used as evidence for a marine environment of deposition ( Picard and High 1963; Gardner 1964; Lovelace and Doebbert 2015;). Anatomical features of an anomalous nothosaur (sauropterygian reptile) Corosaurus alcovensis, found only in the Alcova Limestone, have been used both evidence of environment and age (Storrs 1991; Rieppel 1998; Lovelace and Doebbert, 2015). The Corosaurus is considered a swimming reptile, so it has been called upon as an indicator of a marine environment for the Alcova Limestone. Loveless and Doebbet (2015) used the ${ }^{87} \mathrm{Sr} /{ }^{86} \mathrm{Sr}$ values to fit onto the Triassic ${ }^{87} \mathrm{Sr} /{ }^{86} \mathrm{Sr}$ global seawater curve, suggesting this fit both matches a marine origin and an age of deposition. However, none of these criteria are diagnostic of marine environments because they are also occurring in lacustrine environments (Hardie et al. 2009 and references therein).

The Alcova Limestone is not appropriate for the use of ${ }^{87} \mathrm{Sr} /{ }^{86} \mathrm{Sr}$ analysis. For ${ }^{87} \mathrm{Sr} /{ }^{86} \mathrm{Sr}$ dating to be applied, the unit must be unambiguously marine and unaltered. Interlocking crystal mosaic textures in the Alcova Limestone (Fig. 12A) indicate diagenetic alteration. Elemental maps (Fig. 8,10 , and 13) all show high sulfur and magnesium that do not correspond to bedding planes, further indicating alteration. The Alcova Limestone is not unambiguously marine. The ${ }^{87} \mathrm{Sr} /{ }^{86} \mathrm{Sr}$ ratio of continental rocks record the average strontium isotopic values of the rocks' waters passes over during erosion; therefore, chemical sediments that form in continental environments a possible ${ }^{87} \mathrm{Sr} /{ }^{86} \mathrm{Sr}$ range wider than the ${ }^{87} \mathrm{Sr} /{ }^{86} \mathrm{Sr}$ signatures of seawater. The ${ }^{87} \mathrm{Sr} /{ }^{86} \mathrm{Sr}$ values reported by 
Lovelace and Doebbert (2015) between 0.70816 and 0.70894 are not unambiguously marine. For example, thermal springs around Mono Lake in California have ${ }^{87} \mathrm{Sr} /{ }^{86} \mathrm{Sr}$ from 0.7071 to 0.7089 (Neumann and Dreiss 1995). Lake Edward in Africa has an ${ }^{87} \mathrm{Sr} /{ }^{86} \mathrm{Sr}$ value of 0.7073 (Talbot et al. 2000). The ${ }^{87} \mathrm{Sr} /{ }^{86} \mathrm{Sr}$ values reported from Triassic seawater's conodonts overlap with continental values, reaching a maximum of 0.7082 in the Triassic Olenekian (Korte et al. 2003). However, as the values are non-unique to seawater, other supporting evidence must establish an unambiguous marine origin.

Although the Alcova Limestone marks a significant change in lithology from the underlying red bed siliciclastics, it may represent facies from an adjacent environment that could co-exist in the same climate and general geological setting. The red beds underlying and overlying the Alcova Limestone suggest the same geological setting and climate as the saline lakes interpreted for the Alcova Limestone. Precipitation in a topographic low could be triggered through brine evolution by evapoconcentration (Eugster 1980; Hardie et al. 2009), a decrease in turbidity, and an increase in productivity growth of carbonate binding organisms, or a change in water chemistry (such as $\mathrm{pH}$ ). No transgression of seawater is required to initiate carbonate production in the preexisting environment. Articulated bivalves and gastropods suggest this environment was brackish-saline and low-energy, but not hypersaline. None of the gastropods or bivalves are diagnostic of either marine or lacustrine environments.

The overlying Red Peak Formation is poorly exposed, but there is clear evidence for large scale fluvial systems or soil formation, entirely terrestrial depositional environments. Thus, the red beds bracketing the Alcova Limestone are consistent with deposition as part of terrestrial flooding, authigenic mineral formation, the reworking of that sediment by wind, and soil formation. Taken together, the limestone of the Alcova Limestone and the adjacent red beds represent a stratal stacking pattern diagnostic of an entirely continental environment of deposition.

None of the Alcova Limestone's lithofacies, its conformable units above or below, or any laterally traceable units have any sedimentological, stratigraphic, or paleontological evidence of deposition in open marine, tidal, or beach environments. The stratal stacking patterns and associated erosional surfaces of transgressions have been well established by studying sequence stratigraphy (Posamentier 2009 and references therein). There is no affirmative evidence for deposition in any marine or marine adjacent environment. None of the trace fossils diagnostic of sedimentation in 
the foreshore or strand are present, with all trace fossils either ambiguous or having features of roots. The lamina of the Alcova is of varying thickness without the pattern of tidal rhythmites. The contacts between limestone and clastic sediment are uniformly conformable, with no transgressive lag. The total amount of limestone and the thickest part of the Alcova Limestone is centered near Alcova Reservoir, which marks the formation's lateral center. The Alcova Limestone, though a dramatic lithology change, is best explained as a persistent closed basin lacustrine environment that is fed by sheet floods and groundwater and modified by an arid climate.

\section{The Replacement of Gypsum by Carbonate Minerals}

There is strong evidence that some portion of the Alcova Formation was initially deposited as gypsum and later replaced by carbonate. Many sedimentary structures appear to be pseudomorphs after gypsum (e.g., Fig. 9A and B). A preserved interlocking crystal mosaic indicated some degree of replacement has occurred (Fig. 12 A and D). Elemental mapping demonstrates that residual sulfur, perhaps in the form of gypsum, remains. Gypsum is a common evaporite mineral and widespread in saline lakes ( Lowenstein and Hardie; 1985; Hardie et al. 2009; Matter and Tucker 2009). Gypsum can form through the evolution of seawater, groundwater, or dilute runoff through evapoconcentration, through precursor mineralogy may differ based on the parent brine chemistry (Eugster 1980). As the original lithology in the Alcova Limestone, Gypsum would not foundationally change the environment of deposition.

The replacement of gypsum by calcite can occur as a syndepositional process or later diagenesis ( Ulmer et al. 1990; Anadón et al. 1992; El Tabakh and Schreiber 1994; Sanz-Montero et al. 2006; Benison et al. 2018). Circumstances and characteristics of carbonate replacement of gypsum and anhydrite vary widely, with examples of isolated replacement of specific beds (Kirkland and Evans 1976; Pierre and Rouchy 1988; Anadón et al. 1992), regional replacement of an entire unit (Bell 1989; Benison et al. 2018), and localized alteration of specific features (Speed and Clayton 1975; Sanz-Montero et al. 2006). Three mechanisms have been proposed for the replacement of gypsum or anhydride by carbonate: (1) the post-burial action of sulfur-reducing bacteria consuming migrating oil or another organic source in either a closed or open system, (2) syndepositional replacement of gypsum at the surface, mediated by sulfur-reducing bacteria, and (3) post-burial, non-organic replacement by carbonate saturated groundwater. The replacement of gypsum by calcite can be recognized through the petrographic, isotopic, and stratigraphic context 


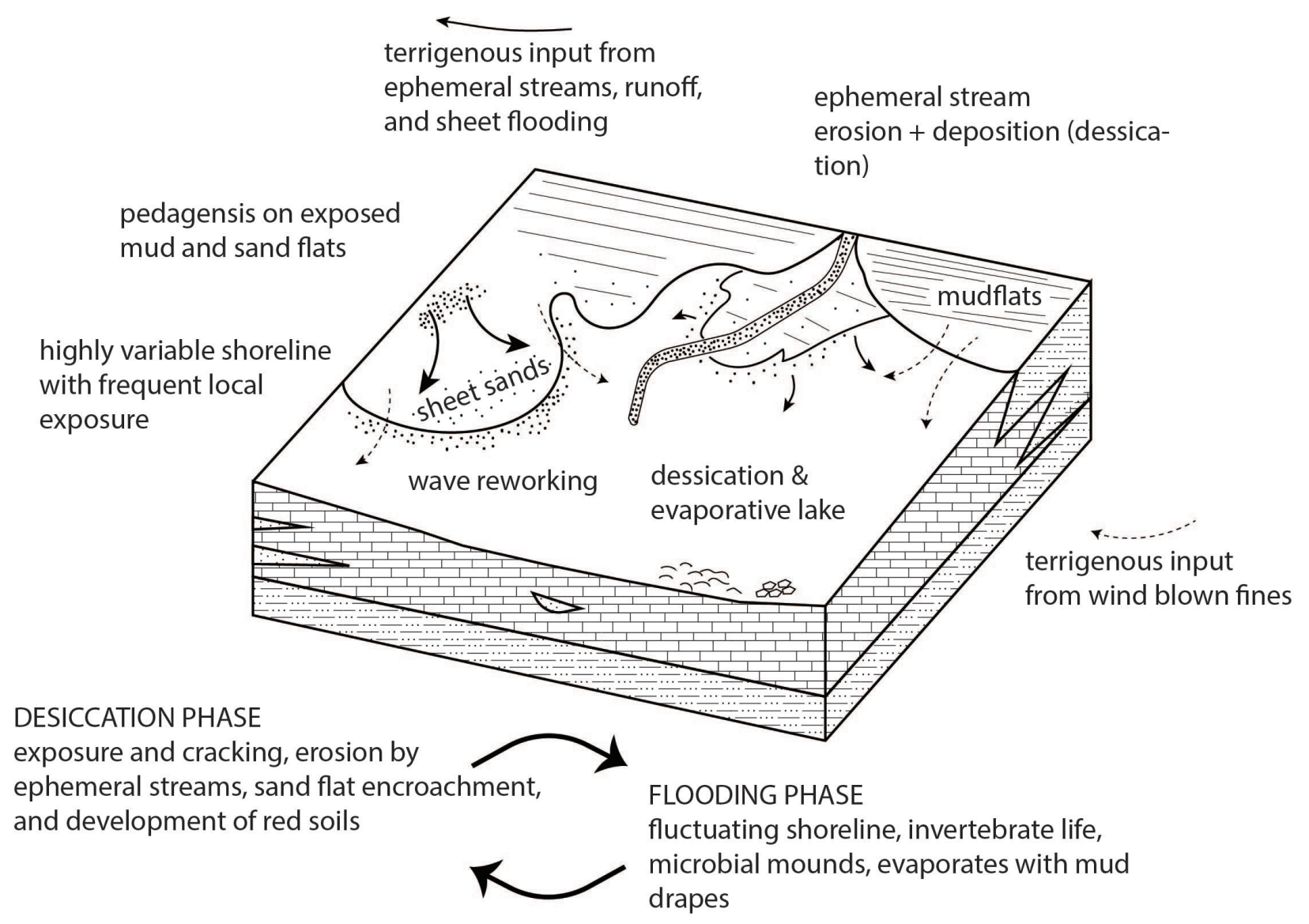

Fig. 14: Facies model for the deposition of the Alcova Limestone and associated units. Limestone or evaporites that are later converted to limestone through diagenesis accurate in an ephemeral lacustrine system. 
Complete replacement of thin stratigraphic units of gypsum and anhydrite with calcite within red beds has been reported from in the Minnekahta Limestone in South Dakota (Benison et al. 2018), limestone beds within the Lockatong Formation of the Newark Basin of New Jersey (E1 Tabakh and Schreiber 1994), and the Codocedo Limestone of the northern Atacama region of Chile (Bell 1989). The Minnekahta Limestone is an isolated limestone within the continental succession, including Permian continental red beds of the Opeche Formation, the Minnelusa Formation, and the Triassic Spearfish Formation (Thomas 1948). The Minnekahta Limestone is composed of an interlocking crystal mosaic of calcite after bedded gypsum (Benison et al. 2018), with visible "ghosts" of bottom growth twinned gypsum. In the Newark Basin of New Jersey, the gypsum and anhydrite of the Lockatong Formation have been replaced by dolomite, calcite, and analcime (El Tabakh and Schreiber 1994). Gypsum replacement with calcite has also been reported from salt domes at the surface in Texas (Kirkland et al. 1976), associated with native sulfur deposits and enhancements in porosity in the near subsurface.

Many of the sedimentary structures in the Alcova Limestone resemble pseudomorphs after gypsum. Gypsum stromatolites have been observed in modern hypersaline environments (Aref, 1998; Taher, 2014), with morphologies that include domes comprised of many smaller domes. Similar multi-structured domes are observed in the crinkle bedded limestone (Fig. 11A and D). Bedded and laminated gypsum are extremely common in the rock record (e.g., Warren 1982; Peryt 1996; Playà et al. 2007). The pinch and swell laminations in the wavy bedded lithofacies (Fig. 10) resemble the varves of gypsum and calcite of the Castile Formation of Texas (Anderson et al. 1972). The clotted pattern observed on the top of the wavy laminated unit (Fig. 9A) resembles the thick sub-rectangular texture formed by the bottom growth of bedded gypsum. Fan-shaped features with no internal laminations in the Alcova Limestone's wavy bedded lithofacies (Fig. 9B and C) resemble gypsum crystal splays. The crinkle (Fig. 12E) in the crinkle bedded limestone (Fig. 11B) is a thick light-colored lamina with smooth bottoms and bladed or triangular tops coupled with thin dark laminations. The thin laminations are silica and iron-rich (Fig. 13). One possible explanation for this pattern is iron oxide precipitation settling on the tops of bottom-growth gypsum, as observed in some Western Australia saline lakes (Benison et al. 2007). Fluid escape structures disrupt some lamina. The features, along with the anomalous sulfur, could be explained by a regional diagenetic event that transformed a mixed gypsum carbonate unit into a carbonate. 


\section{Implications for Facies Models}

The Alcova Limestone is a thin limestone within a thick succession of red beds. Similar patterns of deposition occur in thick red-bed successions around the world. The Codocedo Limestone Member of the Quebrada Monardes Formation in Chile (Bell, 1989) is a $3 \mathrm{~m}$ thick saline lake deposit with many similar features to the Alcova Limestone. Thin limestone and gypsum units within the Goose Egg Formation of Wyoming and the Minnekahta Limestone of North Dakota, South Dakota, and Wyoming (Privrasky et al., 1958; Maughan 1964) are examples of the type. The Minnekahta being a saline lake deposit with evaporites replaced by carbonate (Benison et al. 2018). The Triassic Lockatong Formation's limestone beds of the Newark Basin of New Jersey (E1 Tabakh and Schreiber 1994) are another example of thin limestone units associated with red beds. The occurrence of a thin limestone unit isolated within a thick succession of red beds is not an isolated case but rather a pattern of deposition requiring explanation.

The Alcova Limestone and other similar examples in the western midcontinent represents a short-lived perturbation of the central Pangea hydrologic system. Pre-Alcova terrestrial deposition in a distal alluvial system, the Red Peak Formation, was replaced first with high energy flooding followed by one or more ephemeral saline lakes. Lakes could have formed in preexisting topographic lows through rising groundwater or through alteration in the drainage regime that prevented a previously well-drained landscape from draining (raised spill point). Those lakes accumulated as a single formation, the Alcova Limestone. The depositional environment was not the inundation of the land surface by marine transgression, but rather a regional change in the hydrologic system that resulted in a regional lacustrine system. The transition from predominantly clastic rocks to chemical sediments could result from brine evolution, not a drastic change in environments. The presence of a limestone bed within a red bed succession could simply highlight saline lacustrine environments that were preexisting but harder to recognize due to the ephemeral nature of evaporites (Benison et al. 2015) at the surface and the overprinting of soil features. It is possible that the alteration of gypsum to calcite preserved this lacustrine system while many others within the succession are now lost in geologic time.

\section{Implications for Pangean Environments, Climate, and Paleogeography}

The late Permian and Early Triassic are characterized by extreme aridity, high heat, the proliferation of deserts, and considerable accumulation of evaporates across the agglomerated continent (e.g., Retallack 1999; Loope et al. 2004; Tabor 2013; Gastaldo et al. 2014). For example, 
Zambito and Benison (2013) demonstrated extremely high air temperatures (up to $73^{\circ} \mathrm{C}$ ) and large diurnal temperature ranges (up to $30^{\circ} \mathrm{C}$ ) from fluid inclusions in bedded halite from the Permian Nippewalla Group of western Kansas. Permian and Triassic greenhouse crises were driven by large magmatic provinces and associated coal burning (Retallack 2013 and references therein). Well documented aridity from the middle Permian through the Jurassic can be attributed to global factors such as the global position of the large landmass, supercontinentality, erosion of the central Pangea mountains, long-lasting global seal level low stands and strengthened of monsoons (Tabor and Poulsen 2008 and references therein). This high heat and arid paleoenvironment model for tropical Pangea provides the backdrop for Alcova Limestone deposition.

Surface water in an extremely arid and hot climate would quickly be subject to evaporation and evapoconcentration, even if sourced from dilute rainwater in a monsoonal climate. The assembly of Pangea resulted in many closed basins across the supercontinent, accumulating climate-sensitive sediments such as gypsum, halite, and red beds (Benison et al. 2000; Retallack 2013; Tabor and Poulsen 2008). An extensive saline lake system was developed in the Parnaíba Basin in Brazil, depositing abundant gypsum surrounded by red beds (Abrantes et al., 2016).

Continentality, or the ratio of land to sea and the distance air moves from a moisture source, is considered one of the primary climate factors impacting Pangea's aridity (Kessler et al. 2001; Parrish 1993; Tabor and Poulsen 2008). The ephemeral lacustrine origin for the Lake Alcova's basin extends the Pangea climatic system's continentality further than previously recognized. Additionally, late Permian and Early Triassic red bed and evaporite deposits of the midcontinent become even further isolated from marine sources of moisture and seawater. Previous paleographic reconstructions (e.g., Blakey and Ranney 2008) that incorporate empiric continental seas for the Early Triassic may need to be reconsidered.

\section{CONCLUSIONS}

The carbonate of the Alcova Limestone has three types of carbonate: (1) a sulfur-bearing crystalline carbonate attributed to bacterial sulfate reduction of original limestone, (2) bedded crystalline carbonate, and (3) massive crystalline carbonate. Several lines of evidence suggest the original lithology was a mixture of carbonate, gypsum, and organics. Conformably overlying this succession of carbonates is another red bed, predominantly paleosols. The stratal stacking pattern of the Alcova Limestone and surrounding units is diagnostic of a continental deposition. This 
striatal stacking pattern is distinctive; the pattern in the Chugwater Group is (1) tens of $\mathrm{m}$ red beds with alternating recessive and resistant bed sets, (2) a few of limestone, and (3) a return to red beds with less distinctive bed set patterns. Terrestrial deposition in the Red Peak Formation is dominated by sheet flooding and soil formation. The alternating red beds and calcareous sandstone lithofacies and the basal sandstone lithofacies are transitional, resulting from a perturbation in the hydrologic system either through climate change or an alteration of the watershed. Both lithofacies include evidence for terrestrial and lacustrine deposition. The limestone lithofacies are unambiguously lacustrine, deposited in shallow saline to hypersaline ephemeral lakes.

Sedimentological, stratigraphic, and geochemical observations of the Alcova Limestone strongly suggest that it was not deposited in a marine or marginal marine setting; it was a saline lake system within a larger arid continental setting. This study's implications include a reinterpretation of the paleo-shoreline of Pangea in Wyoming during the late Permian and Early Triassic, refinement of paleoclimate for western low-latitudinal Pangea, and support of a hypothesis that much of Pangea was dominated by saline lakes and red mudflats, sandflats, and paleosols. 


\section{REFERENCES}

Abrantes, F.R., Nogueira, A.C.R., and Soares, J.L., 2016, Permian paleogeography of west-central Pangea: Reconstruction using sabkha-type gypsum-bearing deposits of Parnaíba Basin, Northern Brazil: Sedimentary Geology, v. 341, p. 175-88.

Anadón, P., Rosell, L., and Talbot, M.R., 1992, Carbonate replacement of lacustrine gypsum deposits in two Neogene continental basins, eastern Spain: Sedimentary Geology, v. 78, p. 201-16.

Anderson, R.Y., Dean, W.E., Kirkland, D.W., and Snider, H.I., 1972, Permian Castile varved evaporite sequence, West Texas and New Mexico: Bulletin of the Geological Society of America, v. 83, p. 59-86.

Aref, M.A.M., 1998, Holocene stromatolites and microbial laminites associated with lenticular gypsum in a marine-dominated environment, Ras El Shetan area, Gulf of Aqaba, Egypt: Sedimentology, v. 45, p. 245-62.

Bell, C.M., 1989, Saline lake carbonates within an Upper Jurassic-Lower Cretaceous continental red bed sequence in the Atacama region of northern Chile: Sedimentology, v. 36, p. 651-63.

Benison, K.C. and Goldstein, R.H., 2000, Sedimentology of ancient saline pans: An example from the Permian Opeche Shale, Williston Basin, North Dakota, U.S.A.: Journal of Sedimentary Research, v. 70, p. 159-69.

Benison, K.C., Bowen, B.B., Oboh-Ikuenobe, F.E., Jagniecki, E.A., LaClair, D.A., Story, S.L., Mormile, MR., and Hong, B.Y., 2007, Sedimentology of acid saline lakes in southern Western Australia: Newly described processes and products of an extreme environment: Journal of Sedimentary Research, v. 77, p. 366-88.

Benison, K., Knapp, J., Difrisco, A., and Rasbury, T., 2018, The Permian Minnekahta Limestone: A saline lake gypsum replaced by calcite: The Mountain Geologist, v. 55, p. 59-73.

Benison, K.C., Zambito, J.J., and Knapp, J., 2015, Contrasting siliciclastic-evaporite strata in subsurface and outcrop: An example from the Permian Nippewalla Group of Kansas, U.S.A: Journal of Sedimentary Research, v. 85, p. 626-45.

Blakey, R.C., and Ranney, W., 2008, Ancient landscapes of the Colorado Plateau: Grand Canyon Association.

Bower, R.R., 1964, Stratigraphy of Red Peak Formation, Alcova Limestone, and Crow Mountain 
Member of Popo Agie Formation (Triassic) of central Wyoming [dissertation]: University of Oklahoma, Norman, Oklahoma, 236 p.

Calvo, J.P., Blanc-Valleron, M.M., Rodríguez-Arandía, J.P., Rouchy, J.M., and Sanz, M.E., 2009, Authigenic clay minerals in Continental evaporitic environments: Palaeoweathering, Palaeosurfaces and Related Continental Deposits, v. 27, p. 129-51.

Carini, G.F., 1964, Regional petrographic and paleontologic analysis of the Triassic Alcova Limestone Member in central Wyoming [Dissertation]: the University of Missouri, Columbia, Missouri, 165 p.

Carroll, A.R., and Bohacs, K.M., 1999, Stratigraphic classification of ancient lakes: Balancing tectonic and climatic controls: Geology, v. 27, p. 99-102.

Cavaroc, V. V. and Flores, R.M., 1991, Red beds of the Triassic Chugwater Group, southwestern Powder River Basin, Wyoming: US Geological Survey Bulletin, v. 1917 E,

Decima, A., McKenzie, J.A., and Schreiber, B.C., 1988, The origin of 'evaporative" limestones: an example from the Messinian of Sicily (Italy)': Journal of Sedimentary Petrology, v. 58, p. $256-72$.

El Tabakh, M. and Schreiber, B.C., 1994, Lithologies and diagenesis of the lacustrine sediments of the Lockatong Formation (Upper Triassic) in the Newark Rift Basin: in: SEPM Core Workshop: Special Publications of SEPM.

Eugster, H. P., 1980, Geochemistry of evaporitic lacustrine deposits: Annual Review of Earth and Planetary Sciences, v. 8, p. 35-63.

Eugster, Hans P., and Hardie, L.A., 1975, Sedimentation in an ancient playa-lake complex: The Wilkins Peak Member of the Green River Formation of Wyoming: Bulletin of the Geological Society of America, v. 86, p. 319-34.

Fernández-Díaz, L., Pina, C.M., Astilleros, J.M., and Sánchez-Pastor, N., 2009, The carbonatation of gypsum: Pathways and pseudomorph formation: American Mineralogist, v. 94 , p. 1223-34.

Gardner, H.J., 1964, The Alcova Limestone Member (Triassic) of the Chugwater Formation, Freezeout Mountains [MS Thesis]: University of Wyoming, Laramie, Wyoming, 130 p.

Gastaldo, R.A., Knight, C.L., Neveling, J., and Tabor, N.J., 2014, Latest Permian paleosols from Wapadsberg Pass, South Africa: Implications for changes in climate: Bulletin of the Geological Society of America, v. 126, p. 665-79. 
Hardie, L.A., Smoot, J.P., and Eugster, H.P., 2009, Saline lakes and their deposits: A sedimentological approach: in: Matter, A. and M. E. Tucker (Eds) Modern and Ancient Lake Sediments: Blackwell Publishing Ltd.

Harms, J.C., Southard, J.B., Spearing, D.R., Walker, R.G., Harms, J.C., Southard, J.B., and Walker, R.G., 1975, Stratification and sequence in prograding shoreline deposits: in: Depositional environments as interpreted from primary sedimentary structures and stratification Sequence: Special Publications of SEPM.

Hasiotis, S.T., Kraus, M.J., and Demko, T.M., 2007, Climatic Controls on Continental Trace Fossils: in: Miller, W.I. (Ed.)Trace Fossils: Concepts, Problems, Prospects: Elsevier.

High, L.R. and Picard, M.D. (University of U., 1969, Stratigraphic relations with upper Chugwater Group (Triassic), Wyoming: American Association of Petroleum Geologists Bulletin, v. 53, p. 1091-1104.

Kelts, K. and Talbot, M., 1990, Lacustrine carbonates as geochemical archives of environmental change and biotic/abiotic interactions: Large lakes: Ecological Structure and Function, p. $288-315$.

Kessler, J.L.P., Soreghan, G.S., and Wacker, H.J., 2001, Equatorial aridity in western Pangea: Lower Permian loessite and dolomitic paleosols in northeastern New Mexico, U.S.A.: Journal of Sedimentary Research, v. 71, p. 817-32.

Kirkland, D.W., Evans, R., and Texas, D., 1976, Origin of limestone buttes: Gypsum: AAPG Bulletin, v. 60, p. 2005-18.

Korte, C., Jasper, T., Kozur, H.W., and Veizer, J., 2006, 87Sr/86Sr record of Permian seawater: Palaeogeography, Palaeoclimatology, Palaeoecology, v. 240, p. 89-107.

Korte, C., Kozur, H.W., Bruckschen, P., and Veizer, J., 2003, Strontium isotope evolution of late Permian and Triassic seawater: Geochimica et Cosmochimica Acta, v. 67, p. 47-62.

Kummel, B., 1954, Professional Paper 254-H: Triassic stratigraphy of southeastern Idaho and adjacent areas: US Government Printing Office: United States Department of the Interior, United States Geological Survey.

Lee, W.T., 1927, Professional Paper 149: Correlation of geologic formations between east-central Colorado, central Wyoming, and southern Montana: United States Department of the Interior, United States Geological Survey.

Loope, D.B., Steiner, M.B., Rowe, C.M., and Lancaster, N., 2004, Tropical westerlies over Pan- 
gaean sand seas: Sedimentology, v. 51, p. 315-22.

Love, J.D., 1939, Geology Along the southern margin of the Absaroka Range, Wyoming: Geological Society of America Special Papers, v. 20, p. 1-125.

Love, J.D., 1948, Mesozoic stratigraphy of the Wind River basin, central Wyoming: in: Wind River Basin, Wyoming: 3rd Annual Field Conference Guidebook: Wyoming Geological Association.

Lovelace, D.M., and Doebbert, A.C., 2015, A new age constraint for the Early Triassic Alcova Limestone (Chugwater Group), Wyoming: Palaeogeography, Palaeoclimatology, Palaeoecology, v. 424, p. 1-5.

Lowenstein, T.K. and Hardie, L.A., 1985, Criteria for the recognition of salt-pan evaporites: Sedimentology, v. 32, p. 627-44.

Madole, R.F., Romig, J.H., Aleinikoff, J.N., VanSistine, D.P., and Yacob, E.Y., 2008, On the origin and age of the Great Sand Dunes, Colorado: Geomorphology, v. 99, p. 99-119.

Marzolf, J.E., 1988, Controls on late Paleozoic and early Mesozoic eolian deposition of the western United States: Sedimentary Geology, v. 56, p. 167-91.

Matter, A. and Tucker, M.E., 2009, Modern and ancient lake sediments: (Matter, A. and Tucker, M.E., Eds.) Modern and Ancient Lake Sediments: Blackwell Publishing Ltd.

Maughan, E., 1964, The Goose Egg Formation in the Laramie Range and adjacent parts of southeastern Wyoming: US Geological Survey Professional Paper 50, Department of the Interior, US Geological Survey.

McKee, E.D., Goldsmith, J.W., Ketner, K.B., MacLachlan, J.C., MacLachlin, M.E., Hindle, M., and Rhodes, M., 1959, USGS Numbered Series 300: Paleotectonic maps of the Triassic system: Department of the Interior, US Geological Survey.

Miall, A.D., 1988, Architectural elements and bounding surfaces in fluvial deposits: Anatomy of the Kayenta Formation (lower Jurassic), southwest Colorado: Sedimentary Geology, v. 55, p. $233-62$.

Neumann, K. and Dreiss, S., 1995, Strontium 87/strontium 86 ratios as tracers in groundwater and surface waters in Mono Basin, California: Water Resources Research, v. 31, p. 3183-93.

Parrish, J.T., 1993, Climate of the supercontinent Pangea: The Journal of Geology, v. 101, 
p. 215-33.

Pendleton, R.L. and Jenny, H., 1945, Factors of soil formation: A system of quantitative pedology: Geographical Review, v. 35, p. 336.

Peryt, T.M., 1996, Sedimentology of Badenian (middle Miocene) gypsum in eastern Galicia, Podolia and Bukovina (West Ukraine): Sedimentology, v. 43, p. 571.

Picard, M.D., 1966, Stratigraphy and depositional environments of the Red Peak Member of the Chugwater Formation (Triassic), west-central Wyoming: Rocky Mountain Geology, v. 6, p. $904-26$.

Picard, M.D., 1997, Public Information Circular: Mesozoic history of Wyoming: (Jones, R. W., Ed.) Public Information Circular - Geological Survey of Wyoming: Geological Survey of Wyoming, Laramie, Wyoming.

Picard, M.D., and High, L.R., 1963, Rhythmic alternation in the Triassic Chugwater and Brunswick formations, Wyoming and New Jersey: Rocky Mountain Geology, v. 2, p. 87-99.

Picard, M.D, Aadland, R., High, L.R., and Jr, 1969, Correlation and stratigraphy of Triassic Red Peak and Thaynes Formations, western Wyoming and adjacent Idaho: AAPG Bulletin, v. 53 , p. $2274-89$.

Pierre, C. and Rouchy, J.M., 1988, Carbonate replacements after sulfate evaporites in the Middle Miocene of Egypt: Journal of Sedimentary Petrology, v. 58, p. 446-56.

Pipiringos, G.N., 1968, Correlation and nomenclature of some Triassic and Jurassic rocks in south-central Wyoming: US Geological Survey Professional Paper 594-D, Department of the Interior.

Pipiringos, G.N., and O’Sullivan, R.B., 1978, Professional Paper 1035-A: Principal Unconformities in Triassic and Jurassic Rocks, Western Interior United States: A Preliminary Survey: U.S. Geological Survey Professional Paper 1035-A: Department of the Interior.

Platt, N.H., 1989, Lacustrine carbonates and pedogenesis: sedimentology and origin of palustrine deposits from the Early Cretaceous Rupelo Formation, W. Cameros Basin, N. Spain: in: Wright, V. P., and Tucker, M.E. (Eds) Sedimentology: Blackwell Publishing Ltd.

Playà, E., Cendón, D.I., Travé, A., Chivas, A.R., and García, A., 2007, Non-marine evaporites with both inherited marine and continental signatures: The Gulf of Carpentaria, Australia, at 70 ka: Sedimentary Geology, v. 201, p. 267-85. 
Posamentier, H.W., 2009, Sequence Stratigraphy and Facies Associations: International Associaton of Sedimentologists Special Publication 18: John Wiley \& Sons.

Privrasky, N., Strecker, J., Grieshaber, C.E., and Bryne, F., 1958, Preliminary report on the Goose Egg and Chugwater Formations in the Powder River Basin, Wyoming: in: Powder River Basin of Wyoming: 13th Annual Field Conference: p. 48-55, Wyoming Geological Association.

Reeside, J.B., Applin, P.L., Colbert, E.H., Gregory, J.T., Hadley, H.D., Kummell, B., ... Waage, K., 1957, Correlation of the Triassic Formations of North America Exclusive of Canada: Geological Society of America Bulletin, v. 68, p. 1451-1514.

Retallack, G.J., 1998, Core concepts of paleopedology: Quaternary International, v. 51-52, p. 203-12.

Retallack, G.J., 1999, Postapocalyptic greenhouse paleoclimate revealed by earliest Triassic paleosols in the Sydney Basin, Australia: Geological Society of America Bulletin, v. 111, p. 52-70.

Retallack, G.J., 2013, Permian and Triassic greenhouse crises: Gondwana Research, v. 24, p. $90-103$.

Retallack, G.J. and Huang, C., 2010, Depth to gypsic horizon as a proxy for paleoprecipitation in paleosols of sedimentary environments: Geology, v. 38, p. 403-6.

Retallack, G., and McDowell, P., 1988, Paleoenvironmental interpretation of paleosols: Geology, v. 16 , p. $375-76$.

Riding, R., 2000, Microbial carbonates: the geological record of calcified bacterial-algal mats and biofilms: Sedimentology, v. 47, p. 179-214.

Rieppel, O., 1998, Corosaurus alcovensis Case and the phylogenetic interrelationships of Triassic stem-group Sauropterygia: Zoological Journal of the Linnean Society, v. 124, p. $1-41$.

Sanz-Montero, M.E., Rodriguez-Aranda, J.P., and Calvo, J.P., 2006, Mediation of endoevaporitic microbial communities in early replacement of gypsum by dolomite: A case study from Miocene lake deposits of the Madrid Basin, Spain RID A-1277-2009: Journal of Sedimentary Research, v. 76, p. 1257-66.

Speed, R.C., and Clayton, R.N., 1975, Origin of Marble by Replacement of Gypsum in Carbon- 
ate Breccia Nappes, Carson Sink Region, Nevada: The Journal of Geology, v. 83, p. $223-37$.

Storrs, G.W., 1991, Anatomy and relationships of Corosaurus alcovensis (Diapsida: Sauropterygia) and the Triassic Alcova Limestone of Wyoming: Bulletin of the Peabody Museum of Natural History, Yale University, v. 44, p. 1-151.

Tabor, N. J., 2013, Wastelands of tropical Pangea: High heat in the Permian: Geology, v. 41, p. 623-24.

Tabor, N.J., and Poulsen, C.J., 2008, Palaeoclimate across the Late Pennsylvanian-Early Permian tropical palaeolatitudes: A review of climate indicators, their distribution, and relation to palaeophysiographic climate factors: Palaeogeography, Palaeoclimatology, Palaeoecology, v. 268 , p. $293-310$.

Tabor, N. J., Myers, T.S., and Michel, L.A., 2017, Sedimentologist's guide for recognition, description, and classification of paleosols: in: Zeigler, K.E., and Parker, W.G. (Eds) Terrestrial Depositional Systems: Deciphering Complexities through Multiple Stratigraphic Methods: Elsevier.

Taher, A.G., 2014, Formation and calcification of modern gypsum-dominated stromatolites, EMISAL, Fayium, Egypt: Facies, v. 60, p. 721-35.

Talbot, M.R., Williams, M.a.J., and Adamson, D.A., 2000, Strontium isotope evidence for late Pleistocene reestablishment of an integrated Nile drainage network: Geology, v. 28, p. $343-46$.

Thomas, H.D., 1948, Summary of Paleozoic stratigraphy of the Wind River basin, Wyoming: Wyoming Geological Association.

Tohill, B., and Picard, M.D., 1966, Stratigraphy and petrology of Crow Mountain Sandstone Member, Triassic, Chugwater Formation, northwestern Wyoming: AAPG Bulletin, v. 50, p. 2547-65.

Ulmer, D.S. and Scholle, P.A., 1990, Replacement of evaporites with the Mid-Permian (Leonardian-Guadalupian) Park City Formation, Bighorn Basin, Wyoming: AAPG Bulletin, v. 74, p. 782.

Ulmer, D.S. and Scholle, P.A., 1992, Evaporite replacement within the Permian strata of the Bighorn Basin, Wyoming and the Delaware Basin, West Texas and New Mexico: Abstracts with Programs - Geological Society of America, v. 24, p. 54. 
Warren, J.K., 1982, The hydrological setting, occurrence and significance of gypsum in late Quaternary salt lakes in South Australia: Sedimentology, v. 29, p. 609-37.

Zambito, J.J. and Benison, K.C., 2013, Extremely high temperatures and paleoclimate trends recorded in Permian ephemeral lake halite: Geology, v. 41, p. 587-90. 


\section{CHAPTER 6: CONCLUSIONS}

This dissertation provides the first detailed sedimentological and stratigraphic descriptions of the Permian Goose Egg Formation, the Triassic Red Peak Formation, and the Triassic Alcova Limestone. All three formations were deposited in continental environments in an arid climate and with little macroscopic life.

The second chapter of this dissertation, entitled "Saline Lakes and Loess in the Permian Midcontinent: Paleoenvironments of the Goose Egg Formation, Wyoming (USA)," is projected to be published in the Journal GSA Bulletin. The Goose Egg Formation is comprised of red siltstones, bedded gypsum, and some carbonates. It has extensive halite in the subsurface that has been dissolved at the surface. The Goose Egg Formation was deposited in saline lakes, likely inland ephemeral lakes with rare larger perennial saline lakes. This is the first detailed study of the Goose Egg Formation's sedimentology and the first to conclude that the Goose Egg was deposited in a continental environment. This study provides more evidence that the Goose Egg Formation is not an eastern extension of the Phospohoria Formation. Likely, the Goose Egg Formation is closely related to the extreme environments which deposited the Opeche Shale to the east. Insufficient evidence exists to know how extreme the Goose Egg Formation environments were, but they could be a continuation of the end-member environments of the Opeche Shale. Regardless, the environments at the time of Goose Egg Formation deposition were inhospitable to most life.

The third chapter of this dissertation is entitled "The Permian-Triassic Red Beds of the Red Peak Formation, Wyoming (USA) Part I: Continental Ephemeral Lake Deposits, Loess, and Alluvium Modified by Pedogenesis," and is projected to be published in the journal Sedimentology. This study provides a detailed sedimentological characterization of the Red Peak Formation and debunks the possibility of an origin in a marine environment. Bedsets within the Red Peak Formation have a tabular morphology, even when comprised of diverse sedimentary elements. This sediment stacking pattern is extensively laterally continuous, comprised of many discreet elements resulting from largely unconfined flow (water or wind) over a low-relief distal alluvial fan that was subsequently altered by pedogenesis. Although paleosols seem underdeveloped, micromorphology suggests they may be ferric soils developing on landscapes with long-term stability but little organic matter and few other biotic constituents. 
The fourth chapter of this dissertation is entitled "The Permian-Triassic Red Beds of the Red Peak Formation, Wyoming (USA) Part II: The Origin of Red Pigment from Pre-Depositional and Pedogenic Processes" and is projected to be published in the journal Sedimentology. Three sources for the red pigmentation were identified: (1) impact reddening from eolian transport; (2) in-situ reddening from soil formation; and (3) cementation of iron oxides from acid brines. The thick iron oxide cement played a major role in disseminating oxidized iron species, likely widely distributed by the wind. Sediment was deposited red and become redder with pedogenesis in a warm, oxygenated, arid environment. This study furthers the idea of a third environment for forming red beds: the acid saline lacustrine and groundwater system.

The fifth chapter of this dissertation, entitled "The Alcova Limestone: Saline Lacustrine Environments of the Triassic Chugwater Group, Wyoming (USA)," has been submitted to The Journal of Sedimentary Research and in review. The Alcova Limestone is a thin limestone unit that acts as a cap rock for the cliff-forming Red Peak Formation. This detailed study of the Alcova Limestone's sedimentary features and petrology concludes that it was deposited in ephemeral and perennial saline lakes. It is probable that much of the Alcova Limestone was originally deposited as gypsum and converted to calcium carbonate through diagenesis.

The continental environments of the Goose Egg Formation, Red Peak Formation, and Alcova Limestone record extreme environments covering a large area of Pangea. Taken together, the Permian-Triassic red beds, evaporites, and carbonates form a progression of environments that are consistent with aridification and recovery from the Permian-Triassic extreme climate and environments. Below the Goose Egg Formation are Pennsylvanian rocks that record dunes, perennial lakes, and paleosols. Initiation of Goose Egg sedimentation is mysterious but may be related to some combination of abundant windblown silt, increasing aridity and global warming, or tectonic activity. During Goose Egg time, large perennial saline lakes with possible marine influence were replaced by ephemeral lakes. By Red Peak time, lakes were less common than in the Goose Egg Formation, and unconfined alluvial sedimentation dominated. The Alcova Limestone represents an increase in water availability, most likely an increase in the groundwater table. The red beds above the Alcova Formation are beyond the scope of this dissertation. However, those red beds were deposited by dunes, large-scale fluvial systems in confined channels with lateral accretions, and well-developed paleosols defined by peds, bleached horizons, and root features (Irmen and Vondra, 2000; Tohill and Picard, 1966). This indicated that the Permian-Triassic ecological crisis was a long-lived event, not a single catastrophe. The prevalence of fine-grain 
sediment with an apparent origin in acid saline depositional environments suggests that teleconnections from that environment, perhaps through continent-spanning dust storms, could have global significance.

Further study of the environments of deposition of this succession is encouraged. Three major areas for future investigation are suggested: (1) investigating the lacustrine depositional environments in the Red Peak Formation with detailed studies on the flanks of the Bighorn Mountains; (2) resolving the connections between the Goose Egg Formation and the Red Peak Formation with adjacent red bed units in the Dakotas, Colorado, and Utah; and (3) investigating the subsurface of the Goose Egg Formation and the lower Red Peak Formation. Intensive drilling associated with unconventional oil and gas in the Dakotas and Wyoming offers an opportunity to revisit subsurface correlations between the Goose Egg Formation, Red Peak Formation, and other regional units. Correlations can build a regional framework and refine reconstructions of paleogeography but must be undertaken with consideration of continental facies models. Study of the Goose Egg Formation and lower Red Peak Formation in the subsurface is critical to understand the complete original lithologies before any late-stage, near-surface dissolution of any soluble rocks, such as halite. The nature and origin of brines, including acid saline brines, cannot be elucidated without examining the primary halite in the subsurface.

The red beds of the western United States have been the backdrop for movies and the building blocks of some of the most scenic vistas on The Earth. It was recognized early that these red beds might be a cohesive system (Darton, 1908). This study suggests that Wyoming's red beds are closely related to the larger system of red beds, perhaps through environmental teleconnections. This landscape could have persisted for millions of years. Wyoming's red beds are not outliers among red beds; the lone Permian-Triassic red beds are deposited in marine conditions. Rather, the red beds and associated evaporites and carbonates are consistent with deposition in a continental environment. Continental conditions were required for red bed formation: fine windblown sediment, extensive weathering in a warm oxygenated environment, sediment slow unimpeded by vegetation, and the mega-monsoonal aridity characteristic of the supercontinent. 


\section{Appendix 1 Willow Hill Geochemistry}

$\begin{array}{llll}\# & \text { Lithofacies } & \text { Color } & \text { Depth } \\ 583 & \text { siltstone } & \text { 10R 6/4 } & 0.2 \\ 582 & \text { siltstone } & \text { 7.5 YR 7/4 } & 1.2 \\ 592 & \text { siltstone } & \text { 10 YR 5/6 } & 1.4 \\ 628 & \text { Siltstone } & \text { 10R 5/4 } & 1.6 \\ 629 & \text { Siltstone } & \text { 10R 6/6 } & 5.5 \\ 627 & \text { Siltstone } & \text { 10R 6/3 } & 7.2 \\ 626 & \text { Siltstone } & \text { 2.5Y 8/3 } & 7.8 \\ 607 & \text { Siltstone } & \text { 2.5Y 8/3 } & 8.2 \\ 630 & \text { Siltstone } & \text { 10R 6/6 } & 13.4 \\ 619 & \text { Mudstone } & \text { 10R 4/6 } & 13.8 \\ 612 & \text { siltstone } & \text { 10R 6/4 } & 15 \\ 617 & \text { Siltstone } & \text { 10R 5/6 } & 16 \\ 598 & \text { mudstone } & \text { 10R 5/6 } & 21 \\ 608 & \text { Mudstone } & \text { 10R 4/6 } & 22 \\ 594 & \text { siltstone } & \text { 10R 6/4 } & 24 \\ 577 & \text { siltstone } & \text { 10R 6/4 } & 30 \\ 593 & \text { siltstone } & \text { 10R 6/6 } & 35 \\ 625 & \text { Mudstone } & \text { 10R 6/4 } & 48.5 \\ 575 & \text { siltstone } & \text { 10R 5/4 } & 49 \\ 578 & \text { siltstone } & \text { 10R 5/4] } & 49.5 \\ 595 & \text { siltstone } & \text { 10R 5/6 } & 55.5 \\ 613 & \text { siltstone } & \text { 10R 5/4 } & 56.5 \\ 621 & \text { Siltstone } & \text { 10R 6/6 } & 57 \\ 602 & \text { limestone } & \text { 10R 7/4 } & 59 \\ 574 & \text { siltstone } & \text { 10R 6/6 } & 62.5 \\ 576 & \text { siltstone } & \text { 10R 6/6 } & 63 \\ 579 & \text { siltstone } & \text { 10R 6/6 } & 63.5\end{array}$




$\begin{array}{llll}\# & \text { Lithofacies } & \text { Color } & \text { Depth } \\ 622 & \text { Siltstone } & \text { 10R 5/6 } & 65 \\ 620 & \text { Siltstone } & \text { 10R 5/6 } & 65.5 \\ 605 & \text { Mudstone } & \text { 2.5YR 7/2 } & 66 \\ 590 & \text { Musdtone } & \text { 10 YR 6/6 } & 66.2 \\ 606 & \text { Mudstone } & \text { 2.5Y 8/2 } & 66.8 \\ 610 & \text { Mudstone } & \text { 2.5 Y 7/2 } & 67 \\ 624 & \text { Siltstone } & \text { 2.5Y 7/1 } & 67.2 \\ 585 & \text { Siltstone } & \text { 10R 5/6 } & 70 \\ 633 & \text { Siltstone } & \text { 10R 6/6 } & 73.5 \\ 580 & \text { siltstone } & \text { 10R 4/5 } & 79.5 \\ 581 & \text { mudstone } & \text { 10R 5/6 } & 80.2 \\ 603 & \text { siltstone } & \text { 10R 5/6 } & 82 \\ 616 & \text { Mudstone } & \text { 10R 5/4 } & 83 \\ 589 & \text { Limestone } & \text { 10 YR 7/4 } & 87 \\ 591 & \text { siltstone } & \text { 10 YR 5/6 } & 88 \\ 609 & \text { Mudstone } & \text { 2.5 YR 4/4 } & 89 \\ 618 & \text { Siltstone } & \text { 2.5YR 8/3 } & 92 \\ 635 & \text { Siltstone } & \text { 10R 7/6 } & 94 \\ 604 & \text { siltstone } & \text { 10R 4/6 } & 96 \\ 611 & \text { Mudstone } & \text { 2.5 YR 6/4 } & 101.5 \\ 634 & \text { Siltstone } & \text { 10R 6/4 } & 101.8 \\ 615 & \text { siltstone } & \text { 10R 6/4 } & 102 \\ 614 & \text { siltstone } & \text { 10R 5/6 } & 102.5 \\ 623 & \text { Limestone } & \text { White } & 103 \\ 600 & \text { limestone } & \text { white } & 104 \\ 584 & \text { limestone } & \text { white } & 104.5 \\ 588 & \text { Limestone } & \text { White } & 105\end{array}$
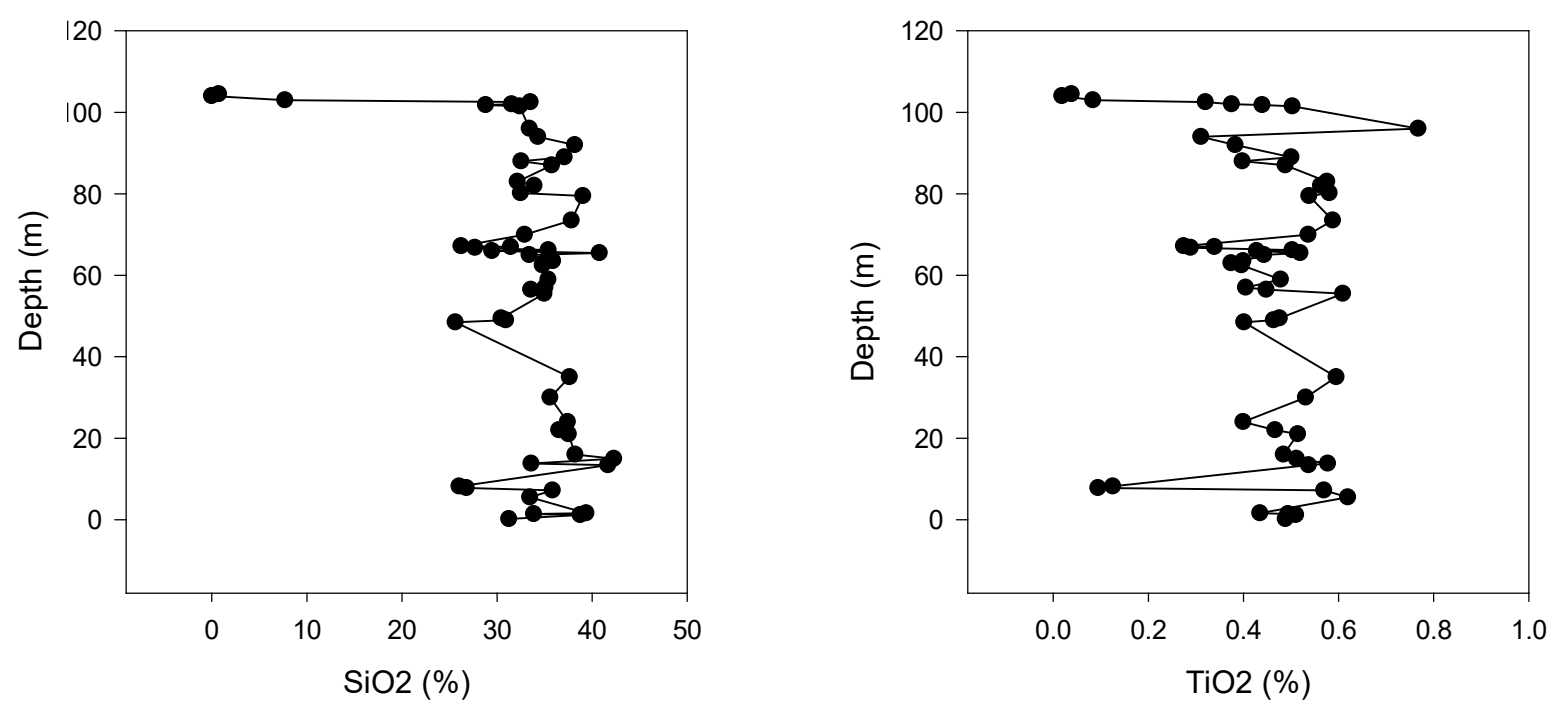

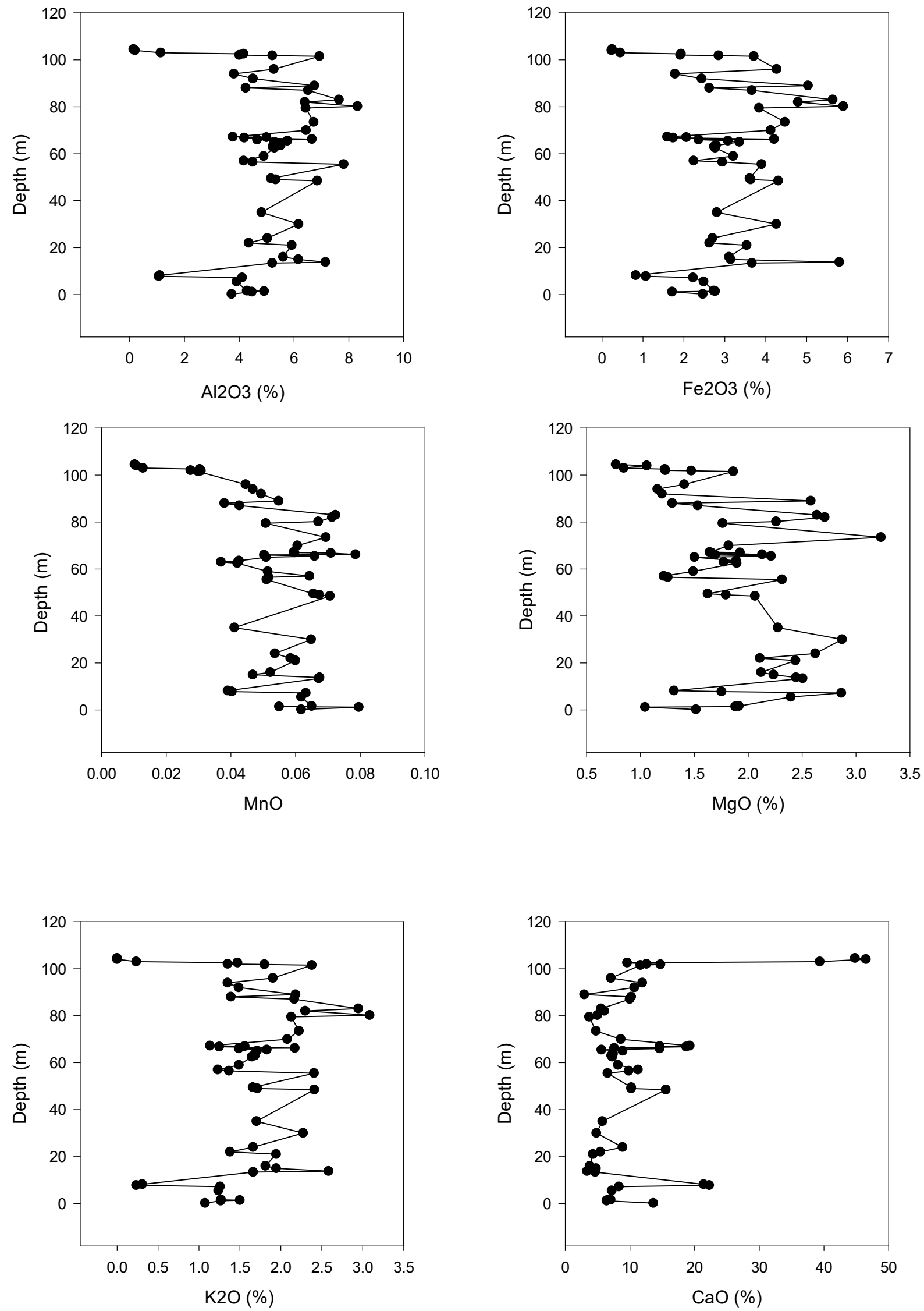


\section{Appendix 2 Automated Mineralogy}


Sample: WH-A1

$\begin{array}{lllll}\text { Name } & \text { Wt\% } & \text { Area\% Area }(\mu 2) & \text { Grain Number } \\ \text { Unknown } & 1.01 & 1.25 & 214486.18 & 8753 \\ \text { Un_x_rayed } & 0.82 & 1.02 & 174193.66 & 85820 \\ \text { Ti Oxide } & 0.3 & 0.2 & 33781.99 & 1216 \\ \text { Quartz } & 26.66 & 25.35 & 4335911.04 & 22950 \\ \text { Pores } & 0.03 & 7.17 & 1226108.61 & 13673 \\ \text { Orthoclase } & 2.38 & 2.31 & 395895.5 & 15664 \\ \text { Muscovite } & 0.24 & 0.21 & 35941.17 & 1822 \\ \text { Micas } & 7.75 & 6.31 & 1079457.43 & 34068 \\ \text { Low_Counts } & 0 & 0 & 243.08 & 10 \\ \text { Hornblende } & 1.3 & 0.99 & 168970.9 & 7899 \\ \text { Fe-oxide } & 0.2 & 0.09 & 16155.72 & 416 \\ \text { Evaporites } & 0 & 0 & 118.05 & 5 \\ \text { Dolomite } & 1.14 & 1 & 171548.33 & 2367 \\ \text { Clay } & 38.75 & 36.29 & 6206913.2 & 27333 \\ \text { Chlorite } & 2.58 & 1.99 & 340554.13 & 9606 \\ \text { Calcite } & 4.2 & 3.85 & 659160.47 & 9433 \\ \text { Apatite } & 0.16 & 0.12 & 20836.47 & 267 \\ \text { Anorthoclase } & 3.06 & 2.93 & 501477.32 & 19797 \\ \text { Albite } & 9.41 & 8.88 & 1518121.32 & 15020 \\ \text { Actinolite } & 0.01 & 0.01 & 1825.33 & 65\end{array}$

Sample: WH-A2

$\begin{array}{lllll}\text { Name } & \text { Wt\% } & \text { Area\% } & \text { Area }(\mu 2) & \text { Grain Number } \\ \text { Unknown } & 0.9 & 1.02 & 2545232.93 & 37941 \\ \text { Un_x_rayed } & 0.27 & 0.3 & 758662.59 & 137342 \\ \text { Ti Oxide } & 0.18 & 0.12 & 311661.64 & 5420 \\ \text { Quartz } & 14.78 & 12.89 & 32305325.85 & 164170 \\ \text { Pores } & 0.07 & 15.55 & 38968044.92 & 5279 \\ \text { Orthoclase } & 2.67 & 2.37 & 5930775.97 & 65900 \\ \text { Muscovite } & 0.2 & 0.16 & 402000.77 & 5723 \\ \text { Micas } & 8.41 & 6.23 & 15610691.38 & 156738 \\ \text { Low_Counts } & 0.36 & 0.4 & 1009343.93 & 475 \\ \text { Hornblende } & 1.35 & 0.93 & 2339652.9 & 30942 \\ \text { Fe-oxide } & 0.09 & 0.04 & 95926.23 & 2181 \\ \text { Gypsum } & 0 & 0 & 2146.36 & 55 \\ \text { Dolomite } & 0.66 & 0.53 & 1320621.29 & 12368 \\ \text { Clay } & 53.92 & 45.95 & 115176651.2 & 70469 \\ \text { Chlorite } & 2.07 & 1.45 & 3635696 & 52308 \\ \text { Calcite } & 2.49 & 2.09 & 5233900.15 & 47612 \\ \text { Apatite } & 0.06 & 0.04 & 97326.79 & 1870 \\ \text { Anorthoclase } & 4.45 & 3.87 & 9709059.34 & 92454 \\ \text { Albite } & 7.06 & 6.05 & 15173034.29 & 94329 \\ \text { Actinolite } & 0.02 & 0.02 & 40449.6 & 357 \\ & & & & 226\end{array}$


Sample: WHA3

$\begin{array}{lllll}\text { Name } & \text { Wt } \% & \text { Area\% } & \text { Area }(\mu 2) & \text { Grain Number } \\ \text { Unknown } & 0.55 & 0.65 & 201479.1 & 10372 \\ \text { Ti Oxide } & 0.13 & 0.1 & 29940.29 & 1912 \\ \text { Quartz } & 5.8 & 5.37 & 1653942.36 & 41999 \\ \text { Pores } & 0.05 & 12.8 & 3946481 & 114473 \\ \text { Orthoclase } & 2.09 & 1.95 & 601042.39 & 22803 \\ \text { Muscovite } & 0.1 & 0.08 & 25211.94 & 1621 \\ \text { Micas } & 13.37 & 10.37 & 3197380.98 & 110419 \\ \text { Low_Counts } & 0 & 0.01 & 1728.23 & 8 \\ \text { Hornblende } & 2.06 & 1.5 & 463354.76 & 22336 \\ \text { Fe-oxide } & 0.09 & 0.04 & 12602.8 & 449 \\ \text { Dolomite } & 0.21 & 0.18 & 55953.83 & 1892 \\ \text { Clay } & 61.93 & 54.91 & 16925288.68 & 25170 \\ \text { Chlorite } & 2.23 & 1.65 & 507369.67 & 26069 \\ \text { Calcite } & 3.11 & 2.71 & 836259.69 & 13755 \\ \text { Apatite } & 0.05 & 0.04 & 11130.34 & 288 \\ \text { Anorthoclase } & 4.79 & 4.38 & 1348849.58 & 48313 \\ \text { Albite } & 2.75 & 2.47 & 762603.43 & 17187\end{array}$

Sample: WH-B1

$\begin{array}{lllll}\text { Name } & \text { Wt\% } & \text { Area\% } & \text { Area }(\mu 2) & \text { Grain Number } \\ \text { Unknown } & 1.17 & 1.54 & 120070.44 & 19643 \\ \text { Un_x_rayed } & 1.16 & 1.53 & 119171.14 & 267814 \\ \text { Ti Oxide } & 0.26 & 0.18 & 14403.43 & 1400 \\ \text { Quartz } & 25.48 & 25.74 & 2004722.7 & 19795 \\ \text { Pores } & 0.01 & 1.74 & 135790.25 & 45384 \\ \text { Orthoclase } & 2.45 & 2.5 & 194687.54 & 31798 \\ \text { Muscovite } & 0.02 & 0.02 & 1604.94 & 418 \\ \text { Micas } & 3.33 & 2.92 & 227551.58 & 28208 \\ \text { Hornblende } & 4.91 & 3.98 & 310025.99 & 49349 \\ \text { Fe-oxide } & 0.29 & 0.15 & 11655.61 & 264 \\ \text { Dolomite } & 10.04 & 9.4 & 731948.45 & 22789 \\ \text { Clay } & 31.4 & 31.44 & 2448690 & 41589 \\ \text { Chlorite } & 2.67 & 2.2 & 171179.85 & 10444 \\ \text { Calcite } & 6.96 & 6.77 & 527064.03 & 918 \\ \text { Apatite } & 0.14 & 0.12 & 9010.69 & 161 \\ \text { Anorthoclase } & 1.73 & 1.77 & 137574.55 & 25217 \\ \text { Albite } & 7.97 & 8 & 622840.96 & 11183\end{array}$


Sample: WH-B2

$\begin{array}{lllll}\text { Name } & \text { Wt\% } & \text { Area\% } & \text { Area }(\mu 2) & \text { Grain Number } \\ \text { Unknown } & 0.62 & 0.8 & 3713991.26 & 44869 \\ \text { Un_x_rayed } & 0.11 & 0.14 & 653435.48 & 159910 \\ \text { Ti Oxide } & 0.15 & 0.12 & 549694.9 & 6913 \\ \text { Quartz } & 11.45 & 11.46 & 52909583.55 & 220133 \\ \text { Pores } & 0.02 & 3.93 & 18142990.55 & 6831 \\ \text { Orthoclase } & 5.65 & 5.72 & 26400301.11 & 168088 \\ \text { Muscovite } & 0.1 & 0.09 & 419588.76 & 4321 \\ \text { Micas } & 6.08 & 5.21 & 24047102.65 & 183807 \\ \text { Low_Counts } & 0.04 & 0.05 & 221818.02 & 594 \\ \text { Hornblende } & 7.39 & 5.89 & 27167528.89 & 170886 \\ \text { Fe-oxide } & 0.05 & 0.03 & 116358.33 & 1949 \\ \text { Evaporites } & 0 & 0 & 2381.47 & 39 \\ \text { Dolomite } & 5.45 & 5.06 & 23354383.02 & 137609 \\ \text { Clay } & 53.61 & 52.63 & 242937175.4 & 107129 \\ \text { Chlorite } & 1.64 & 1.32 & 6101162.33 & 64108 \\ \text { Calcite } & 0.23 & 0.22 & 1013646.75 & 2778 \\ \text { Apatite } & 0.05 & 0.04 & 172163.61 & 1793 \\ \text { Anorthoclase } & 3.21 & 3.22 & 14850329.91 & 106420 \\ \text { Albite } & 4.03 & 3.97 & 18338652.85 & 90473 \\ \text { Actinolite } & 0.13 & 0.11 & 495464.62 & 3918\end{array}$

Sample: WH-B3

$\begin{array}{lllll}\text { Name } & \text { Wt\% } & \text { Area\% } & \text { Area }(\mu 2) & \text { Grain Number } \\ \text { Unknown } & 0.83 & 1.11 & 1826615.45 & 24083 \\ \text { Un_x_rayed } & 0.07 & 0.09 & 156507.09 & 34781 \\ \text { Ti Oxide } & 0.22 & 0.16 & 271520.47 & 3930 \\ \text { Quartz } & 27.29 & 28.01 & 46201141.26 & 78933 \\ \text { Pores } & 0 & 0.58 & 954077.13 & 3048 \\ \text { Orthoclase } & 3.18 & 3.31 & 5462996.57 & 53335 \\ \text { Muscovite } & 0.09 & 0.08 & 133779.47 & 1773 \\ \text { Micas } & 3.66 & 3.24 & 5340229.51 & 58373 \\ \text { Low_Counts } & 0 & 0 & 1390.46 & 39 \\ \text { Hornblende } & 5.27 & 4.34 & 7161113.76 & 68538 \\ \text { Fe-oxide } & 0.16 & 0.08 & 138039.32 & 1701 \\ \text { Dolomite } & 9.64 & 9.15 & 15095697.18 & 65704 \\ \text { Clay } & 29.77 & 30.29 & 49963631.6 & 112555 \\ \text { Chlorite } & 2.09 & 1.74 & 2871941.82 & 32013 \\ \text { Calcite } & 5.57 & 5.5 & 9069563.81 & 9431 \\ \text { Apatite } & 0.14 & 0.12 & 198721.3 & 1510 \\ \text { Anorthoclase } & 2.03 & 2.1 & 3459039.96 & 33295 \\ \text { Albite } & 9.54 & 9.72 & 16033013.01 & 45758 \\ \text { Actinolite } & 0.43 & 0.38 & 625234.52 & 4774\end{array}$




\begin{tabular}{lllll}
\multicolumn{4}{l}{ Sample: WH-C1 } & \multicolumn{3}{l}{$l$} \\
Name & Wt\% & Area\% & Area $(\mu 2)$ & Grain Number \\
Unknown & 1.15 & 1.51 & 372646.61 & 14283 \\
Un_x_rayed & 0.33 & 0.44 & 107926.96 & 43413 \\
Ti Oxide & 0.2 & 0.15 & 36716.74 & 932 \\
Quartz & 30.36 & 30.76 & 7587690.88 & 23835 \\
Pores & 0 & 0.73 & 180008.58 & 7535 \\
Orthoclase & 4.44 & 4.6 & 1133576.4 & 11405 \\
Muscovite & 0.18 & 0.17 & 42198.46 & 1646 \\
Micas & 9.66 & 8.29 & 2045150.76 & 44723 \\
Hornblende & 1.95 & 1.59 & 391488.29 & 15690 \\
Fe-oxide & 0.12 & 0.06 & 15670.83 & 250 \\
Dolomite & 0.53 & 0.49 & 122012.99 & 990 \\
Clay & 28.13 & 28.69 & 7077705.08 & 43948 \\
Chlorite & 1.69 & 1.39 & 343640.57 & 7380 \\
Calcite & 9.65 & 9.41 & 2319885.64 & 17869 \\
Apatite & 0.14 & 0.11 & 27948.67 & 220 \\
Anorthoclase & 3.9 & 3.98 & 982795.37 & 18620 \\
Albite & 7.56 & 7.61 & 1877671.36 & 10881 \\
Actinolite & 0 & 0 & 181.52 & 4
\end{tabular}

\begin{tabular}{|c|c|c|c|c|}
\hline \multicolumn{5}{|c|}{ Sample: WH-C3 } \\
\hline Name & $\mathrm{Wt} \%$ & Area\% & Area $(\mu 2)$ & Grain Number \\
\hline Unknown & 1.59 & 2.03 & 9250216.78 & 73605 \\
\hline Un_x_rayed & 0.12 & 0.15 & 671412.8 & 163861 \\
\hline Ti Oxide & 0.13 & 0.1 & 461984.99 & 6137 \\
\hline Quartz & 16.19 & 15.86 & 72262737.65 & 137538 \\
\hline Pores & 0.02 & 4.83 & 22010189.73 & 4640 \\
\hline Orthoclase & 8.03 & 7.99 & 36385651.44 & 166893 \\
\hline Muscovite & 0.39 & 0.35 & 1590068.72 & 9644 \\
\hline Micas 6.15 & 5.22 & 237963 & $22.71 \quad 134420$ & \\
\hline Low_Counts & 0.01 & 0.02 & 70225.56 & 691 \\
\hline Hornblende & 5.16 & 4.07 & 18522627.74 & 83048 \\
\hline Fe-oxide & 0.05 & 0.03 & 123277.74 & 2590 \\
\hline Gypsum & 0 & 0 & 1592.7 & 23 \\
\hline Dolomite & 7.36 & 6.68 & 30435884.38 & 94016 \\
\hline Clay & 42.78 & 41.28 & 188028848.2 & 176455 \\
\hline Chlorite & 1.64 & 1.31 & 5964483.13 & 55143 \\
\hline Calcite & 0.54 & 0.51 & 2332877.59 & 4719 \\
\hline Apatite & 0.06 & 0.04 & 202450.25 & 2636 \\
\hline Anorthoclase & 2.96 & 2.93 & 13346140.74 & 66086 \\
\hline Albite & 6.62 & 6.45 & 29380261.06 & 71276 \\
\hline Actinolite & 0.18 & 0.15 & 706060.41 & 3681 \\
\hline
\end{tabular}



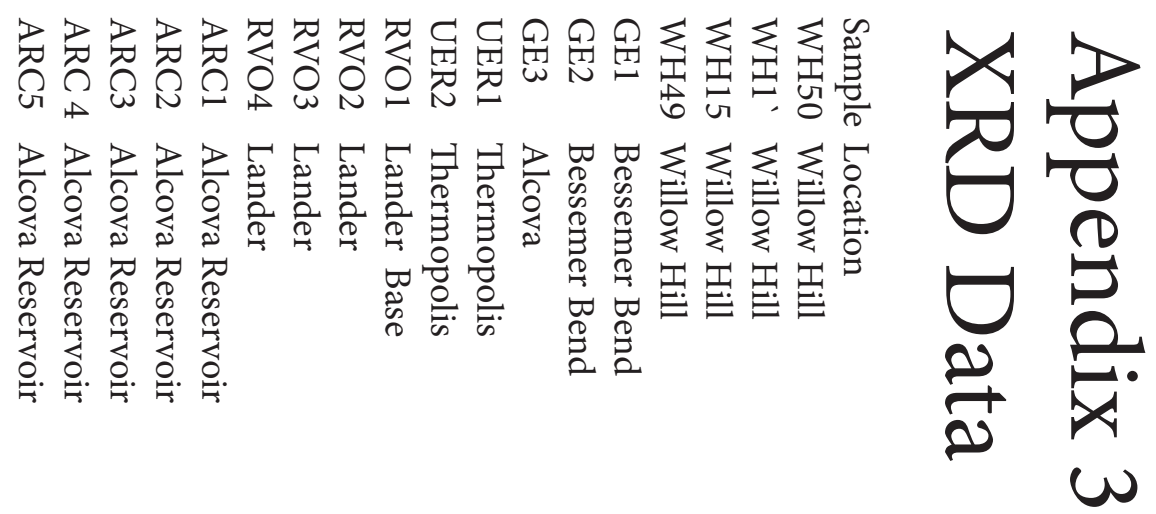

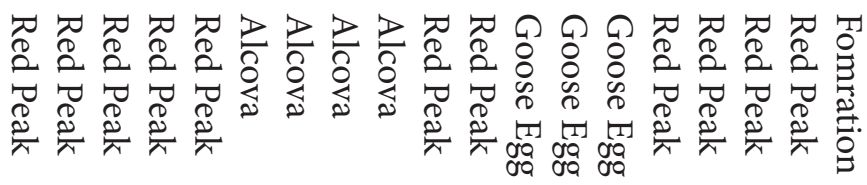

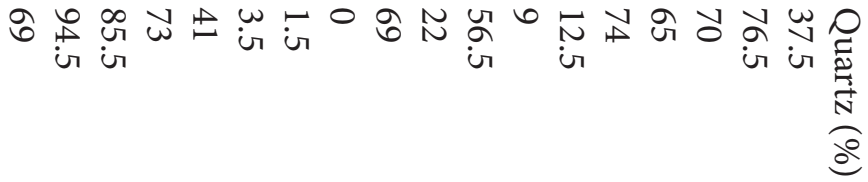

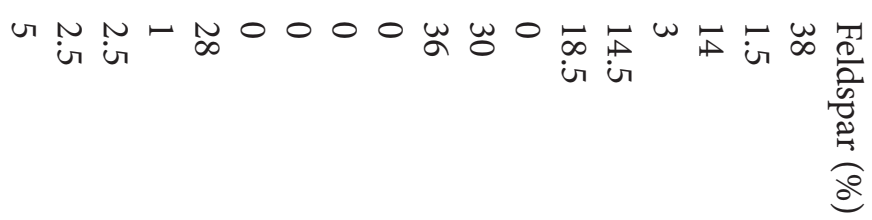

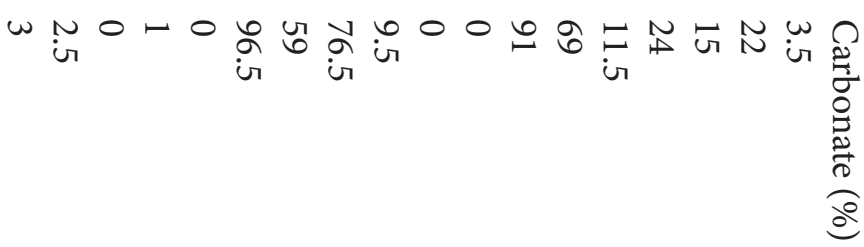

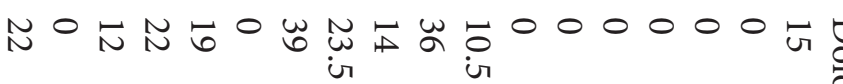

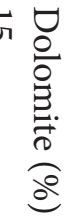

0 i $0 w 0000-00000$ ir $00 w \boxminus$

$\frac{0}{\frac{0}{0}} \frac{0}{d}$

- 000 n 0 ir 0 ir $9 w 000$ ir

$\frac{0}{2}$ 